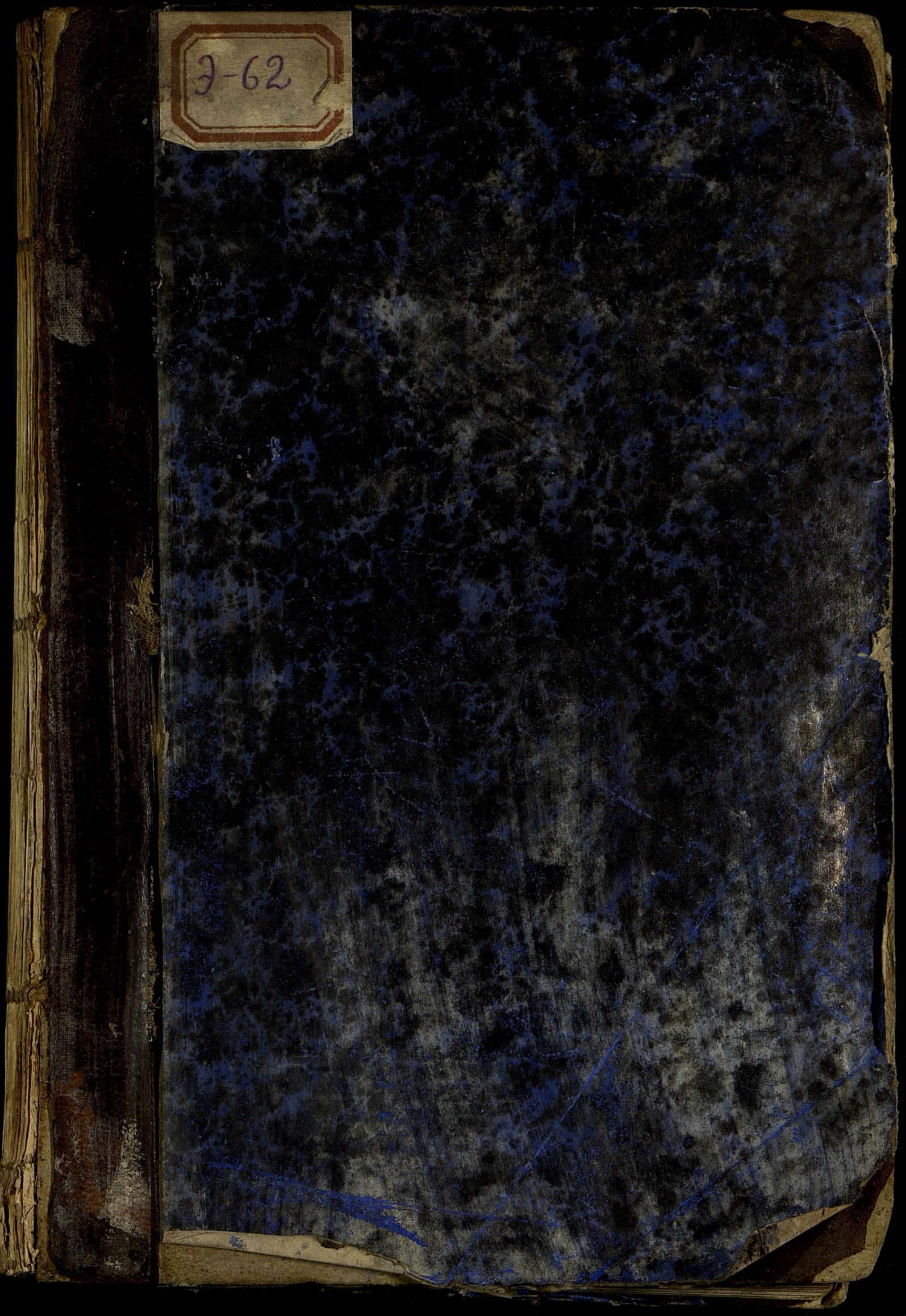


STI

6.

10. 


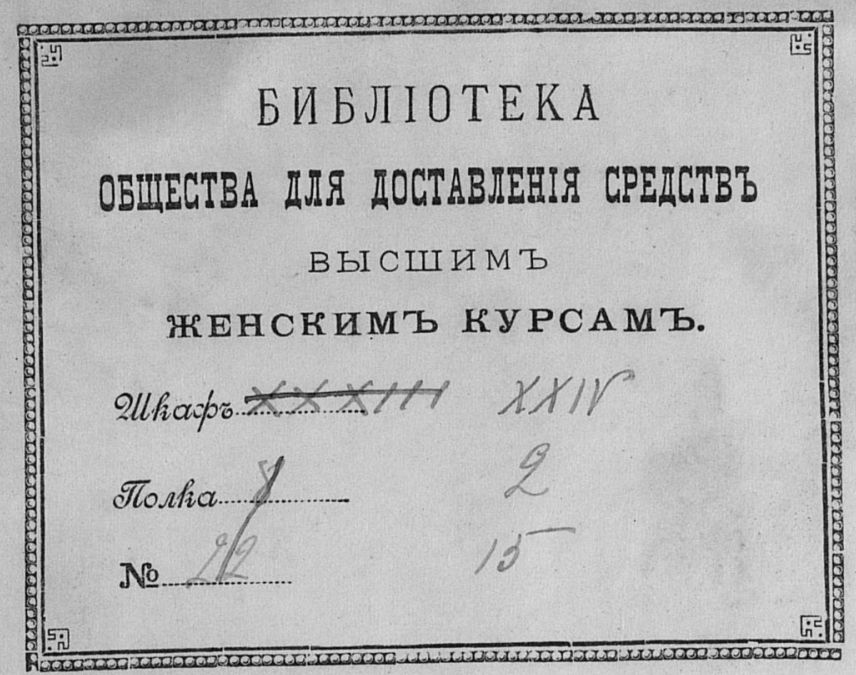




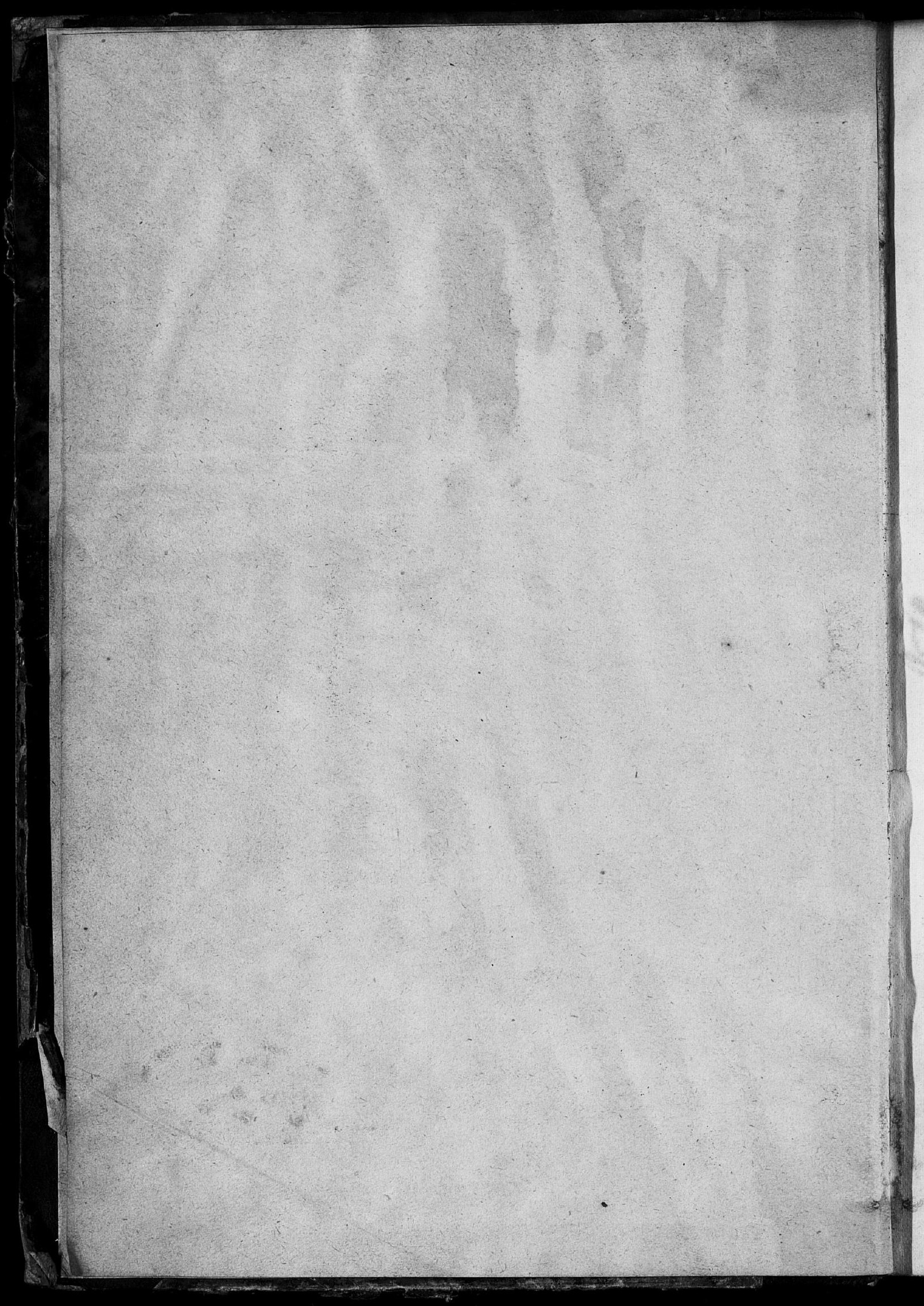


З А ІІ И С К И

Льва Николаевича

ЭНГЕЛЬГАРАТА. 


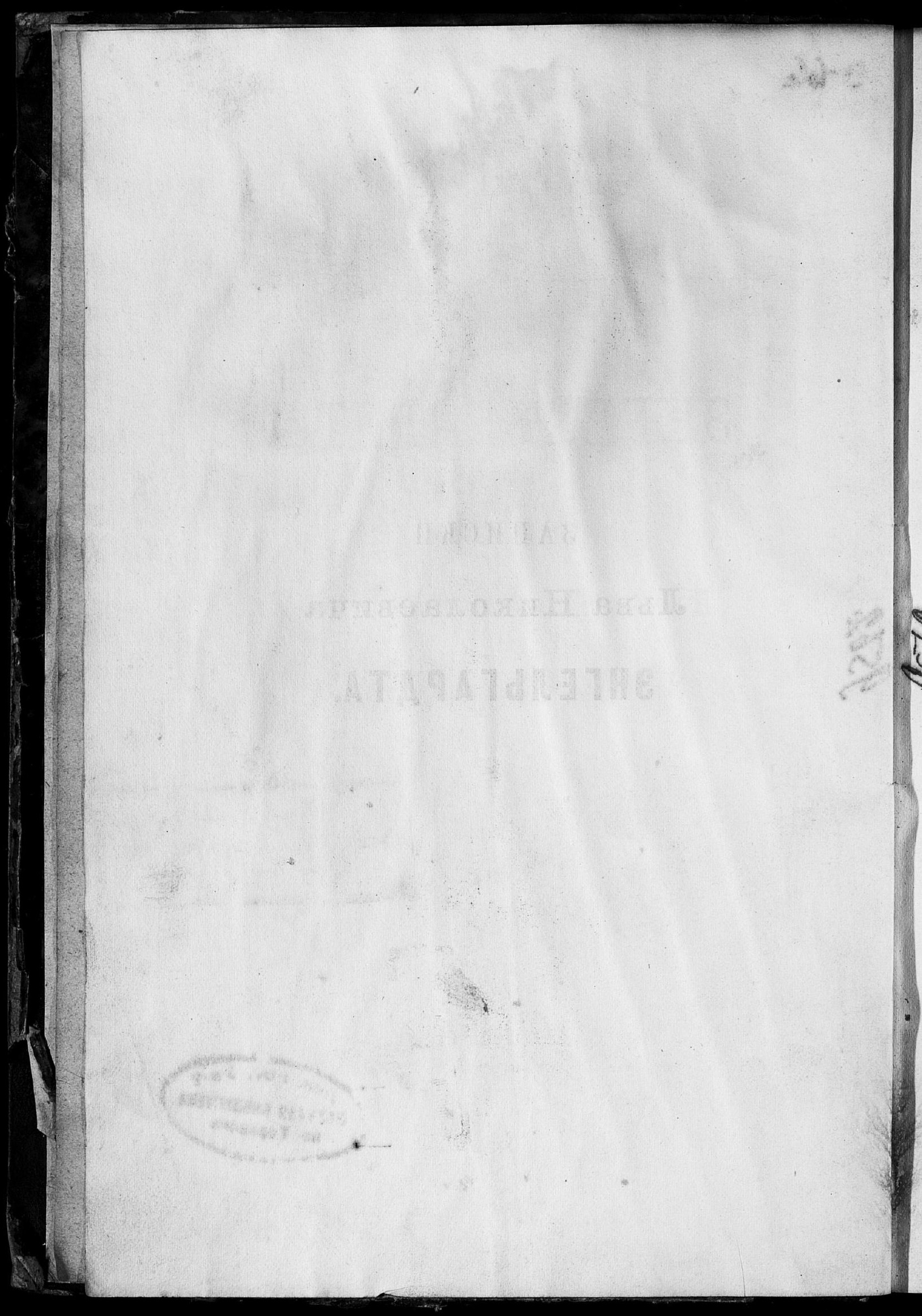




\title{
ЗАПИСКИ
}

\section{ЛЬВА НИКОЛАЕВИЧА}

\section{ЭНГЕЛЬГАРДТА.}

\author{
$1766-1836$.
}

\section{Изданіе «Русскато Архива».}

(Съ примъчаніями и уғазателемъ).

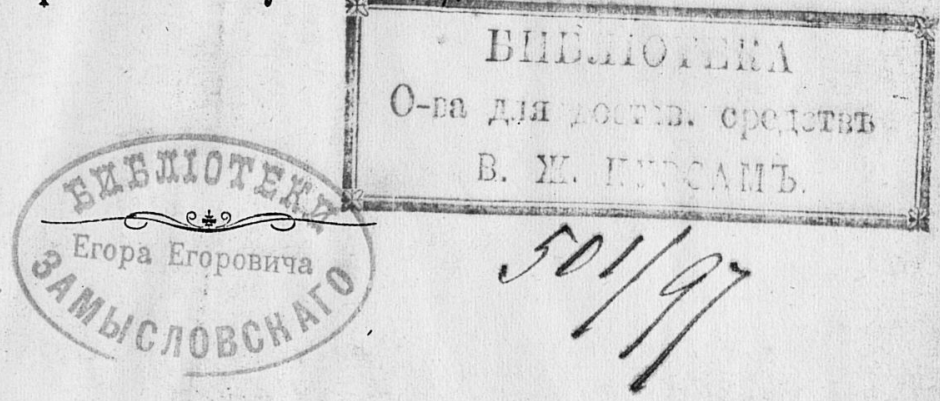

M O C K B A.

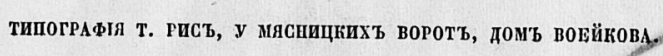

1868. 


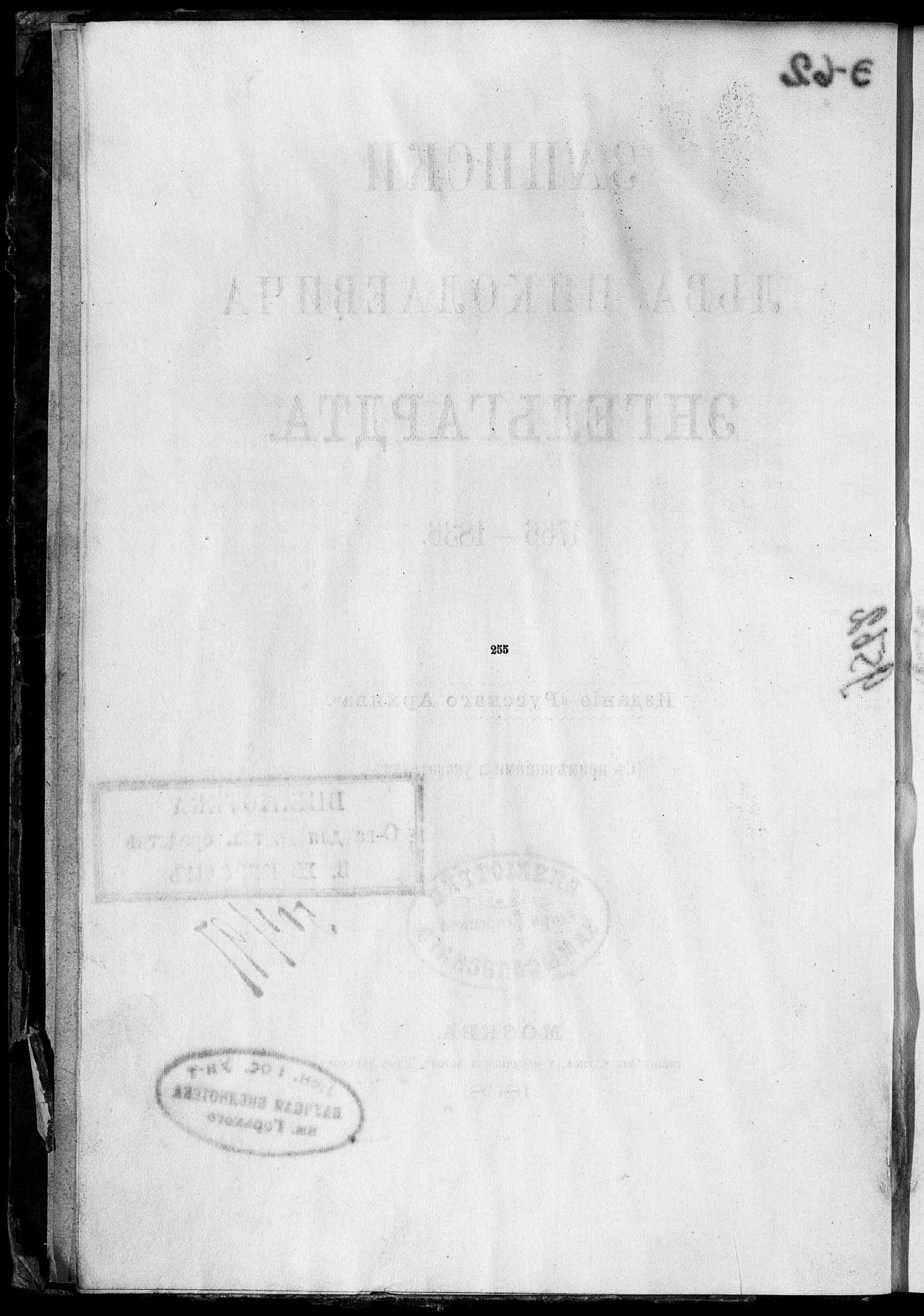


Записки Льва Николаевича Энгельгардта были первоначально напечатаны Николаемъ Васильевичемъ Путятою въ Русскомъ Въстникъ 1859 года, и сверхъ того выпущены въ небольшомъ числьъ отдъъльныхъ оттисковъ, которые быстро разошлись по ругамъ. Нынъ, съ довволенія Н. В. Путяты, любопытныя Записки эти издаютея вновь, въ болье полномъ противъ прежняго видг. Примъччанія къ нимъ, составленныя М. Н. Лонгиновым'ъ, овначены буквами $M$. Л.; принадлежащія Н. В. Путять, буквами Н. ПІ.; а тъ̌, при коихъ ничего не означено, писаны самимъ авторомъ Записокъ. II. $\boldsymbol{E}$.

$$
\text { * * }
$$




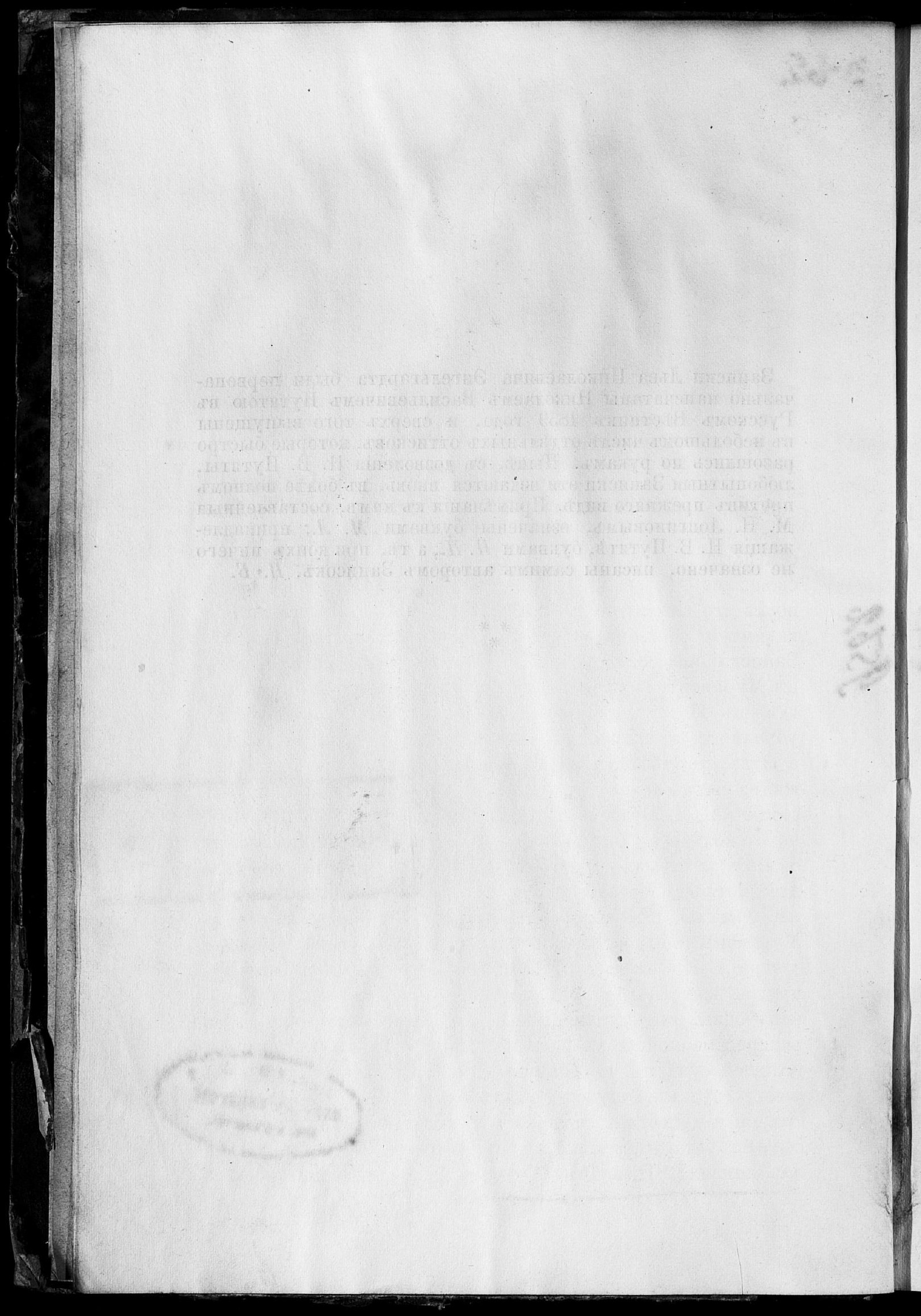




\section{ПРЕДИСЛОВІЕ.}

Авторъ этихъ Записокъ, отставной генералъ-майоръ Левъ Николаевичъ Энгельгардтъ, при жизни своей читаль ихъ семейству своему и нъкоторымъ короткимъ пріятелямъ. Онъ скончался 4-го ноября 1836 г. въ Москвъ. Въ первое время посль̆ его смерти не хватились его Записокъ, и онъ̌ потом' какимъ-то образомъ затерялись. Можно было полагать, что Записки Јьва Николаевича оставались въ имънніи его, сельцъ Мурановъ̆, Московской губерніи, въ Дмитровскомъ уъздъ̆, гдъ̌ онъ обыкновенно проводиль часть года. Тамъ, въроятно, убрали ихъ съ кипами разныхъ ненужныхъ бумагъ и газетъ, а какъ въ посльдсствіи и старый домъ, въ которомъ онъ жилъ, быль сломанъ, то, казалось, исчезли и посльвдніе ихъ сльвд. А. Я. Булгаговъ, знагомый съ этими любопытными, по словамъ его, Записками, неоднократно спрашивалъ меня о нихъ и тьыъ поддерживаль во мнъ желаніе отыскать ихъ, хотя всъ прежніе распросы мои объ этомъ были тщетны. Осенью 1858 г., я находился въ помянутомъ сельцъ Мурановъ (оно досталось по наслььдству жень моей, младшей дочери Л. Н. Энгельгардта, котораго старшая дочь была супругою извъстнаго нашего поэта Е. А. Баратынскаго). Наконецъ одинъ изъ мурановскихъ дворовыхъ старожиловъ, по распросамъ моимъ, указалъ мнъь въ амбарьи, возль конюшни, большой сундукъ, наполненный разнымъ хламомъ; тутъ-то, между грудами полуистльвшихъ бумагъ съ домашними счетами и въдомостями, открылъ я тетрадки Записокъ Л. Н. Энгельгардта, вложенныя въ толстой рукописи, переведенной имъ книги: Le Triomphe de l'Evangile. $Я$ съ жадностію бросился 
на Записки и, бйлло прочитавъ ихъ, привезъ сюда. Здъ̌сь я предложиль чтеніе ихъ небольшому кружку людей, способныхъ быть вйрными цйнителями моей находки. Простота, ясность и чистосердечіе разсказа, занимательныя подробности о старинъ, псторическое значеніе нйкоторыхъ событій, коихъ авторъ быль свидь̆телемъ, и вообе какой-то характеръ правдивости возбудили самый живой интересъ къ этимъ Запискамъ во всъхъ, овнагомившихся съ ними въ рукописи. Убъдясь въ этомъ, я ръшился напечатать ихъ, не касаясь почти ихъ слога. Извъстный своими критическими и библіографическими статьями М. Н. Лонгиновъ, по блатосклонности своей и по страсти къ письменнымъ памятникамъ прошлыхт временъ, обогатилъ Записки Л. Н. Энгельгардта большимъ числомъ примъчаній, касающихся до лицъ и происшествій, упоминаелыхъ въ нихъ, и до хронологіи событій. Пользуюсь случаемъ изъявить ему искреннюю благодарность 'за услугу, огазанную имт тағимъ образомъ памяти моего покойнаго тестя. Конечно, читатели Записокъ будуть ему тагже благодарны съ своей стороны.

H. IІутята.

26-го ноября 1858 г.

Москва. 


\section{ЗАПИСКИ Л. Н. ЭНГЕЛЬГАРАТА.}

\section{I. Вет у Ілен іе.}

Записки каждаго частнаго лица 0 тощъ, тто́ случилось видъть, слышать или чего быть свидъттелемь въ жизни, каґъ бы оно ни было малозначуще въ свътть, всегда могуть быть интересны для будущихъ временъ, касательно нравовъ того въъа, людей, образа жизни, обычаевъ, политическихъ и военныхъ пропсшествій и описанія знаменитыхъ лищъ.

Я сожальью, что занялся симь уже поздно, гогда мнъ минуло шестьдесятъ ль̌тъ; многое интересное забыто, а что́ и вспомниль, то уже не такъ върно, какъ должно бы было быть въ связи съ теченіемъ вренени. Занятіе это доставило мнґ удовольствіе вспоминать счастливое вреня юности; разсказывать же 0 прошедшенъ, гакъ говорить г. Сегорь, есть единственное удовольствіе для стариковъ. Эти записки я началь писать въ 1826 г., сльддственно все случившееся посль, дошедшее до моего свъдънія, будетъ подробнъе ${ }^{1}$ ).

Отецъ мой былъ дъйствительный статскій совътниғъ и кавалеръ св. Владиміра 2-й степени, Николай Богдановичъ;

1) Это намъреніе не было приведено въ исполненіе: Л. Н. Энге дьгардтъ не успъль довести своихъ запиисокъ и до того времени, въ которое началь писать ихъ. Онъ скончался 4 ноября 1836 г. 
мать моя была изъ рода Бутурлиныхъ; Надежда Петровна; замьчательно, что онъ изъ сшоленскихъ дворянъ ${ }^{2}$ ) былъ въ числ'ъ первыхъ, женившихся на Великороссіянкъ, пбо со временъ завоеванія царемъ Алексъемъ Михайловичемъ Смоленска ${ }^{3}$ ), они, по привязанности ґъ Џольш', брачились вначальъ съ Польками, но какъ въ царствованіе императрицы Анны Іоанновны были запрещены всякія связи и сношенія съ Поляками, даже ежели у кого находили польскія книги, того ссылали въ Сибирь; то сперва по ненависти къ Русскимъ, а потомъ уже по обычаю, всь Сиольяне женились на Смольянкахъ. Поэтону, можно сказать, всъ споленскіе дворяне между собою сдыллались въ родствъ. Первый женился на Русской Яковъ Степановичъ Аршеневскій, второй-отецъ свъ̌тльйшаго внявя Григорія Александровича Потемкина ${ }^{4}$ ).

1766. Я родился въ 1766 году февраля 10 числа въ Смоленской губерніи, Духовскаго уъзда, въ деревнъ Зайцовъ, родовонъ пиъніи отца моего, готорое дано было қоролемъ польскимъ Спгизундомъ ${ }^{3}$ ), по взнтіи Споленска, предку нашему, генералъ-лейтенанту Вернеру Энгельгардту, ґурляндцу, служившему у него въ войски, какь сказано въ жалованной грамотьъ: za krwawe zaslugi przeciwko Moskwy, dajemy dobra, то есть: «ва гровавыя заслуги противъ

${ }^{2}$ ) Смоленскіе дворяне Энгельгардты поселились тамъ еще до Петра - Великаго и совершенно обрусъили; пхъ не надо смъ̌шивать съ Энгельгарптами, уроженцами Остзейскаго края, изъ коихъ пріобрйлъ себъ общую извъ̌стность достойнъйшій директоръ Царскосельскаго лицея Егоръ Антоновичь Энгельгардтъ. II. Б.

3) Сиоленскъ взять Русскими 20 сентября 1654 года и остался за Россіею по Андрусовскопу перемирію, заключенному съ Польшей 30 января 1667 г. M. I.

4) Слг. Русскій Архивъ 1867, стр. 588 и з96. Мать кн. Потемкина была изъ роду Скуратовыхъ. ПІ. Б.

5) Сигизмундъ III царствовалъ сь 1587 по 1632. годъ. $M$. $\mathbb{A}$. 
Москвы жалуемъ имънія и проч. ) Назвали меня Харлампіемъ; но когда привезенъ я былъ родителями моими въ Нижегородскую губбернію, Арзамасскаго уъ̌зда въ село Ћирманы, къ бабъъ̆ моей Натальъ Өедоровнъ̌, то она, въ память сына ея Јьва, убитаго въ Семиль̌тнюю войну, назвала меня его имененъ; я воспитывался у нея до пяти ль̌ть, т0-есть до самой ея смерти.

1771-1773. Бабка моя отдала свое имъ̆ніе, 1.200 душъ, своимъ дочерямь, то-есть моей матери и теткъ моей, бывшей вамужемъ за Стремоуховымъ, оставя себъ на прожитіе 100 душъ; по дешевизнъ̆ въ то время сельскихъ произведеній и по несуществованію водяной коммунигащіи, доходъ ея едва простирался до ста рублей. Однакожь она довольствовалась симъ доходощъ, не бывъ въ тягость своимъ дътямъ и не входя въ долги.

Физическое мое воспитаніе сходствовало съ системою Руссо, хотя бабка моя не только не читала сего автора, но едва ли знала хорошо россійскую грамоту. Зимою иногда

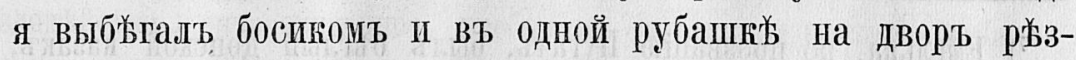
виться съ ребятишгами, и закоченб̌въ весь оть стужи, при-

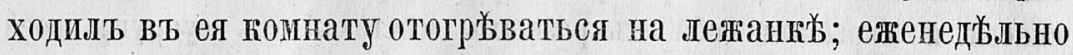
меня мыли и парили въ банъ въ санонъ жарконъ пару и оттуда въ оттрытыхъ саняхъ возили домой съ версту. Кормился я самою грубою пищей и отъ того сдъзлался самаго грҺшкаго сложенія, перенося, безъ вреда моему здоровью, жаръ, холодъ и всякую пищу; вовсе не учился, и можно сказать, быль самый избалованный внучекъ.

1774. По сперти бабюи, отецъ щой, бывъ полковникомъ въ отставкъ̌, опредъ̌ленъ воеводою въ отобранную отъ Польши БЪлоруссію ${ }^{6}$ ), въ городъ Витебскь', и взяль меня съ с0-

6) БЪълорусскій край съ 1,800,000 жителей окончательно присоединенъ къ Россіи, по первому раздъ̆лу Польши на основаніи договора 7 сентября 1773 года, заклгченнаго Россіею, Австріего и Пруссіею съ Польшей. $\boldsymbol{M}$. $\boldsymbol{I}$. 
бою. Оставить военную службу заставило его крайне разстроенное его состояніе: онъ задолжалъ тетнъ своей бригадиршъ Витковичевой, жившей въ Малороссіи, въ мъстечгъ Сарочинцахъ, три тысячи рублей. По тогдашнему, сей долгъ былъ неоплатный, пбо доходы въ низовыхъ губерніяхъ почти ничего не значили, рожь продавалась тамь по двадцати пяти попьекъ четверть, да и ту не гуда было сбывать; водяной коммуникаціи вовсе не было, виногуренныхъ заводовъ было мало. Свазанная Витковичева столь была не снисходительна, тто принуждала отца моего ежегодно пріъзжать для переписки векселя изъ Выборга, гдљ̌ полкъ, въ которомъ онъ служилъ, былъ на непремъннныхъ квартирахъ; таковая поъздка чрезвычайно его разстроила. Какъ доходы были малы и отецъ съ семействощъ жиль почти однимъ жалованьемъ, то не прежде могъ онъ долгъ сей заплатить, кағъ когда пожаловано было егу трп тысячи рублей за разореніе имъннія матери моей партіею бунтовщика Пугачева ${ }^{7}$ ).

7) Емелька, по прозванію Пугачъ, быль бъглый Донской казакъ, выдававшій себя ва пмператора Петра III, разглашая, что будто онъ спасся и скрывалъ себя въ разныхъ местахъ отъ супруги своей императрицы Екатерины, распространившей слухъ о его смерти, что наконецъ рьшился онъ прибыть и ввърить себя Яицкимъ казакамъ, напоминаль присягу и требовал' от'ь нихъ пособія взойдти опять на прародительскій престолъ. Сіи казаки, бывъ въ совершенномъ не-

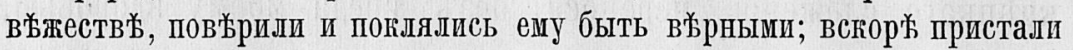
къ нему Башкирцы и другая сволочь, а особливо господскіе престьяне и дворовые люди; онъ объщаль имъ вольность, не брать съ нихъ ни податей, ни рекрутъ, а соль давать безденежно. Дворянъ, готорые ему попадались, въьшаль, а жень и дочерей ихъ, наругавшись ими, раздавалъ своимъ сообщникамъ. Начало сего бунта возникло при огончаніи Турецкой войны 1771 года, и продолжался оный около двухъ ль̌тъ, докольь собрались войска подъ главнымъ предводительствомъ генерала графа Петра Ивановича Панина. Во всей Россіи народъ былъ въ чрезвычайномъ волненіи; ежели оы Пугачевъ пошель къ Москвъ, а не занимался бы долю въ УФимской и близь лежащихъ губерніяхъ, то 
1775. По прізъддъ въ Витебскъ, началь меня учить грамот各 уніятской церкви дьячокъ, и кают я былъ избалованный внучекъ, то едва въ два года выучился порядочно читать.

много бы золъ Россія претерпьљла; но онъ не имйлъ ни ума, ни твердости пользоваться своимъ дерзгимъ предпріятіемъ; онъ подходилъ къ Казани п выжегъ всю, громъ грйпости, которой требовалъ сдачи, но майоръ Иванъ Ивановичъ Михельсонъ съ небольшимъ отрядомъ попоспъ̆ль и разоилъ его на Арскомъ поль. У Пугачева было тогда болье 20,000, и онъ имъль артиллеріг. Посль этого онъ бъ̆жалъ къ Симбирску, а потомъ на Яикъ, гдъъ тъими же казаками, бывшими его первыми сообщниками, быль схваченъ и выданъ командующему въ ть̆хъ предъ̆лахъ именитому герою, тогда бывшему генералъ-майоромъ, Суворову. Императрица угазала ръ̌ку Яигъ переименовать въ Уралъ, а ғазаковъ именовать Уральскимъ войскомъ. Пугачевъ былъ приве-

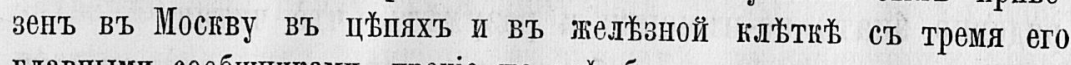
главными сообщниками, прочіе же всъ были прощены.

Императрица предала самозванца судить синоду, сенату и военному генералитету; такъ кағъ въ Россіи смертная газнь была отмънена, а злодййство, имъ учиненное, требовало особливаго постановленія,синодальные члены в'b опредъ̆леніи своемъ сказали, что Пугачевъ и сообщники его заслуживаготъ смертную ғазнь, но по духу христіанскому и духовному своему званію, они, синодальные члены, не пгогутъ подписать приговора. Прочіе члены суда опредйлили: Пугачева четвертовать и потомъ отрубить еиу голову, главному его наперснику тағже отрубить голову въ Москвъ, что̀ и исполнено; одного ивъ его сообщниковъ повъсить въ УФъ, а другаго въ Уралъ. JI. Э.

(Графъ Петръ Ивановичъ Панинъ, генералъ-аншефъ, родоначальникъ нынЊшнихъ грабовъ Паниныхъ, родился 1721 г., ум. въ Мо-

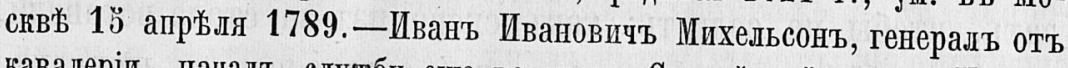
кавалеріи, началъ службу еще во время Семиль̌тней войны. $\mathrm{У}_{\mathbf{M}}$ в въ Бухаресть 19 августа 1807 г. - Битва на Арскомг поль̈ происходила 12 и 13 авг. 1774 г.-Свъ̌тлййій князь Александръ Васильевичъ Италійскій, грабъ Суворовъ Рымникскій, генералиссимусъ, родился въ Москвъ 13 ноября 1729, ущеръ въ С.-Петербургъ 6 мая 1800 года. Пугачевъ представленъ быль гъ нему въ начал'ъ октября 1774 года. - Пугачевъ казненъ въ Москвъ, на Болот٪, 10 января 1775 года. M. ЛI.) 
1776. Тогда приставили кө мнљ учителя, отставнаго поручика Петра Михайловича Брауншвейга, учить меня писать по-русски, первынъ правилаиъ ариөметики и по-нъмецки, ва шестьдесять рублсй въ годъ, а учиться по-французски ходиль я въ іезуитскій монастырь къ іезуиту Вольфорту; но можно сказать, что отъ таговыхъ учителей мало показывашь успь⿱хха, по тупоумію и льннсти.

1777. Въ посль̆дствіи къ старшей моей сестрж Варварж Николаевнъ ${ }^{8}$ ) выписана была изъ Вильны madame Leneveu за 500 рублей; вмъ̌сть съ нею я учился щъљый годъ и уже говориль по-французски изрядно; тогда же по-нъмецги училь меня іезуитъ Кацаврикъ, готорый исправно всякую недъљю наказывалъ меня дисциплиною, отчего я получиль тақое омерзъніе къ нъмецкому язығу, что никогда не могъ порядочно знать по-нёнецки и разумтьть, что̀ читаю.

Тогда же записанъ я быль вь гарнизонъ сержантомъ. Полковнику Древичу, за заслуги его противъ польскихъ конФедератовъ, пожалованы были, въ Витебской провинціи, деревни, и кромъ того онъ чрезвычайно обогатился во вреия своихъ дъйствій въ Польшь. Отецъ мой оказываль ему разныя услуги по сему имьнііо, почему, по прибытіи его въ Витебскъ, опредъълилъ (онъ) иеня въ гусарскій вербованный Бълорусскій полюъ падетомъ. Ч по ребячеству моему помню, въ какощъ я быль восхищеніи, гогда одъљли меня въ гусарскій мундиръ, а всего больье забавляла меня сабля съ ташкою.

A быль самыхъ дурныхъ склонностей, ничего не могъ сказать, чтобы не солгать; какъ скоро изъ-ва стола вставали, тотчасъ объгаль столь и все, что́ оставалось въ рюмкахъ, выпиваль съ жадностію, краль всякія лакомства и все украденное клалъ въ ташку; неръдљо приводили неня съ поличнымъ къ матери моей, готорая с 0 слезами говорила: «0динъ

8) Вторая моя сестра, Александра Николаевна отдана была въ Смольный монастырь. 
у меня сынъ, но какого ожидать отъ него утӹшенія при таковыхъ порочныхъ склонностяхъ!) Ни наказанія, ни увъщанія, ничто меня не исправляло; сверхт того я быль неловокъ, неопрятенъ, и станъ мой быль кривъ и сутуловатъ: воть какую я объщаль моимъ родителямь радость!

1778. Тағимь я быль до 1778 года. Тогда открылись намьстничества, и отецъ мой помьщенъ быль въ Полоцкъ предсьљдателемъ гражданской палаты, а меня отвезли въ Смоленскъ, въ пансіонт къ содержателю Әллерту, гдъ пробыль я годъ. Правду сказать, хотя онъ касательно наукт былъ малосвъдущт, и вся учебная дыятельность его состолла въ сокращеннощъ преподаваніи всъхъ наукъ, тоесть катихизиса, грамматики, исторіи, географіи, миөологіи, безъ мальйшаго толюованія, и въ принужденіи учеников'ь затверживать наизусть Франпузскія фразы; но за то строгостію содержаль пансіонъ въ порядкеъ, на совершенно военной дисциплинъ: билъ безъ всякой пощады за мальйшія вины ферулами изъ подошвенной кожи и деревянными лопатками по рукамъ, сь̌каль розгами и плетью, ставиль на Ћольнии на три и четыре часа; словомь, совершенный быль тиранъ. Но, кажется, для меня таковой и былъ нүженъ, чтобы перемћнить злую мою нравственность. Какъ я имьљль дурную память, то не проходило дня, въ который не быль я наказанъ; но усп'зваль я очень хорошо въ ариөпетикељ и геометріи, которымъ училь насъ отставной артиллерійскій сержанть, Осипь Ивановичъ Овсянниковъ, отличавшій меня передъ всьми прочими; также успььвалъ я въ танцованіи и фехтованіи, чему училь самъ Әллерть. Французскій языкъ тоже пель хорошо по навыку, ибо никто не смбъль ни одного слова сказать по-русски, для чего учреждены были іежду учениками начальники: младшіе означались краснымъ бантомъ въ петлиць и надзирали надъ четырьмя учениками, а старпіе чиновники отличались голубымъ бантомъ и надзирали надъ двумя младшими чиновниками; 
всь они должны были смотрбть, чтобы никто не говориль по-русски, не шалилъ, и училт бы наизусть уроки, заданные для другаго дня. Младшіе пиъли право наказывать, если кто скажетъ слово цо-русски, однимъ ударомъ по рукъ ферулою, а старшіе чиновники-по два удара. Если Эллертъ узнавалъ, что сіи чиновниги худо исполняли свою должность, или во зло употребляли власть, имъ данную, то наказывальь ихъ ужаснымъ образом'ь, а иногда лишалъ бантовъ. Чтобы заслужить такой знакъ отличія, надобно было вести себя хорошо и прилежно учиться. Я почитаю, что поощреніе это много способствовало ґъ нравственности, но впрочемъ все было основано на побонхъ. Изъ учениковъ отъ тағоваго славнаго воспитанія много было изуродовано, однакожь пансіонь быль всегда полонъ. За таковое воспитаніе платили сто рублей въ годъ, на всепъ сөдержаніи Эллерта, кронг платья. Танцъ-боденъ быль два раза въ недъъг; много было дъввиць, которыя пріззжали учиться танцовать и за выучку платили по тридцати рублей, даже и взрослыя; однакожь и имъ не было спуспу: одна была дъъвица Лебедева, очениь непонятная, одинъ разъ онъ отбилъ ей руки о спингу стула при многолюднощъ собраніи; но до совершеннаго обученія менуэта и контратанцов'ь никто не бралъ свопхъ дҺ̌тей обратно. Сравните теперь воспитаніе того времени съ нынъшнимъ, и върно мало тому повърите. 0днакожь касательно мальчиковъ, вь самодержавномъ правительствњ, ущ̌ренная строгость не лучше ли неупотребленія тъ̌леснаго наказанія? Нужно, чтобы они съ юности попривыљли даже и къ несправедливостямъ ${ }^{9}$ ).

Черељъ годъ взяли меня изъ пансіона и привезли въ Полоцкъ. Въ кагощъ восхищеніи были мои родители, увидя меня выправленнаго, псправившагося отъ пороков'ь, танщую-

9) Современные наставники юношества конечно обратятъ вниманіе на это извлеченное иъъ опыта замъัчаніе Л. Н. Энгельгардта. 
щаго на балахъ, говорящаго изрядно по-французски и о всъ̌хъ наукахъ, хотя я говорилъ ғакъ попугай, ничего не понимая, и потому вскорґ все заб̆ылъ!

Между тъиъ Древичъ представилъ меня въ аудиторы, хотя мнь̆ было только тринадцать Іъть; но кагь ему досталось въ генералъ-майоры, а полгъ принялъ мой внучатный дядя, Василій Васильевичъ Энгельгардтъ, племянникъ свътльйшаго княвя Потемкина, то въь мъсто аудитора перевель иеня въ гвардію въ Преображенскій полкъ сержантомъ, въ число служащихъ, а не недорослей ${ }^{10}$ ).

0тецъ мой былъ пожалованъ вице-губернаторомъ въ Могилевъ. Генералъ-майоръ Зоричъ ${ }^{11}$ ) выбылъ изъ случая, при чемъ пожаловано было ему пьстечко ПІкловъ съ тринадцатью тысячами душъ. Первое употребленіе монаршей милости было то, что онъ завель училище, выписаль хорошихъ учителей; въ ономъ я учился еще одинъ годъ. Въ посльъдствіи сіе училище названо кадетскимъ корпусомъ, и въ немъ было до трехъ соть кадетовъ. Государыня дала гривилегію этому Зоричевскому корпусу, чтобы по экзамену принимать кадетовъ въ армію оФиңерами, и многіе изъ нихъ были съ большиши свъддъ̆ніями, а особливо въ математикъ. По сиерти Зорича казна приняла корпусъ на свой коштъ,

10) Большею частію всг̌ дворяне ваписывали своих'ь дъътей въ гвардію, смотря по связямъ ихъ, капралами, унтеръ-офицерами и сержантами; не имйвшіе же случая, записавъ малольтнихь своихъ дъ̆тей недорослями, брали ихъ къ себъ для воспитанія до возраста; старшинство ихъ считалось по вступленіи въ настоящую службу, а случайные вносились въ списокъ служащихъ; тогда давали имъ паспорты до окончанія наукъ. Въ одномъ Преображенскомъ полку считалось болье тысячи сержантовъ, а недорослямъ не было и счету.

11) Семенъ Гавриловичъ Зоричь, Флигель-адъютанть и генеральъмайоръ. Онъ былъ родомъ Сербъ. Усп安и его при дворь продолжались не болье года; онъ убххаль въ. Шкловъ въ іюнь 1778 и вскорћ основаль тамъ училище. Умерь въ 1799 году генералъ-лейтенантомъ, чинъ котораго получилъ при Павлье I. $M$. $J$. 
помьстила сперва въ Сиоленск年, потомъ въ Гродно, а въ 1812 году оный переведенъ въ Кострому; нынь состоитъ въ Москвь ${ }^{12}$ ):

По окончаніи года взять я быль изь онаго училища и, для обученія практической геометріи и теодевіи, отданъ оберь-ґвартирмейстеру Матвею Михайловичу Щелину, который по дружбж къ моему отцу училь меня, какь своего сына, въ 0ршть; жиль же я тамъ у генералъ-майора Б....... Изъ благодарности умолчу о немь, но пребываніе мое у него въ домь много сдтылало мнеь вреда касательно нравственности.

Симъ заключилось мое воспитаніе.

\section{II. Время до прибытія мосго на служоб вт Преображен- скій полкт й нкоторые анекдоты.}

Еще во время пребыванія моего въ Шкловскошъ училищъ̆, вышель изъ случая Иванъ Николаевичъ Корсаковъ ${ }^{13}$ ) а мъсто его заступијъ и при дворъ сталъ имйть большое вліяніе Александръ Дмитріевичъ Јанской ${ }^{\text {`4}}$ ). Корсакову пожаловано было въ Могилевской губ́ерніи 6000 душъ, 200,000 рублей для путешествія въ чужіе краи, брилліантовъ и жемчуговъ было у него, какъ циннили тогда, болье нежели на

12) 1-й Московскій кадетскій корпусъ; нынъ̆ 1-я военная гимнавія, помьщающаяся въ Головинскомъ дворцё. M. I.

13) Иванъ Николаевичъ Корсаковъ, также не долго польвовавшійся значеніемъ при дворъ. Въ іюнґ 1778 назначенъ онъ флигель-адъютантомъ и пожалованъ генералъ-майоромъ, а въ онтябрь 1779 оставиль Петербургъ. Онъ родился въ 1754 г., ум. въ 1831 году. Нъсколько собственноручныхъ записоюь къ нему импер. Екатерины II-й хранится въ Чертковской библіотегег. $M$. $d \boldsymbol{l}$.

14) Александръ Дмитріевичъ Ланской, генералъ-адъютантъ и генералъ-поручикъ. Род. 8 марта 1758 , ум. 20 іюня 1784. Онъ пожалованъ быль флигель-адъютангомь въ свбтлле воскресенье 1780, и придворные успхххи егө продолжались до самой его смерти. $M$. I. 
400,000 руб.; с суда по ныне шнему гурсу, имъль онъ денегъ и вещей на 2. 400,000. Пақъ въ жалованныхъ ему деревняхъ еще не было построеннаго дома, то выпросиль онъ у тамошняго помйщика Іезофовича деревню Желивль, верстахъ въ тридцати отъ Могилева, куда и пріхзжали кі́ нему всъ родственники его изъ Сщоленской губерніи; не ръдко и отецъ мой съ семействомъ своимъ ъзжалъ туда же и меня оралъ съ собою. Какъ ни огроменъ былъ въ Желивль домъ, и накъ ни уного было при немъ службб, но тьъснота бывала ужасная: въ одной гомнать্ помъщалось фамиліи по двъ; ежедневно одни прібзжали, другіе уъзжали, но менъе осьмидесяти человъьъ ниғогда не бывало; при таковомъ множествъ господъ, сколько перебывало людей и лошаяей? Боль্е шести мисяцевъ тилъ онъ таговьгъ образомъ; все, что́ можно придумать къ увеселенію и роскоши, все было придумано; посему, а еще болье по безпорядку ${ }^{15}$ ), онъ въ короткое время прожиль много изъ данныхъ ему на путешествіе денегъ. व для того написаль сіе въ началь главы, чт0 впервые тогда началь пользоваться обществомъ, помышлять нравиться обоего пола людямъ и заслуживать къ себъ вниманіе.

1779. Въ 1779 году отецъ мой призыванъ быль вообще со всъми вице-губернаторамп къ императриц' Екатеринь Великой. Она хотъла узнать оть самыхъ лиць, поимъ ввърены казенныя имущества, о доходахъ каждой губерніи и отчетахъ и обстоятельствахъ пространной своей имперіи; видъ̌ть и узнать каждаго, кому поручены ея финансы.

Я слышалт отъ отца моего, въ какую подробность и төнвость она входила, разспрашивая каждаго глазъ на глаз'ь; многіе лишены были своихъ мъ̌стъ, нногихъ, при первыхъ отьрывшихся мъстахь, пожаловала она въ губернаторы и иныя государственныя должности, по способности каждаго;

15) Не только его слуги, но и люди гостей пивали шампанское. 


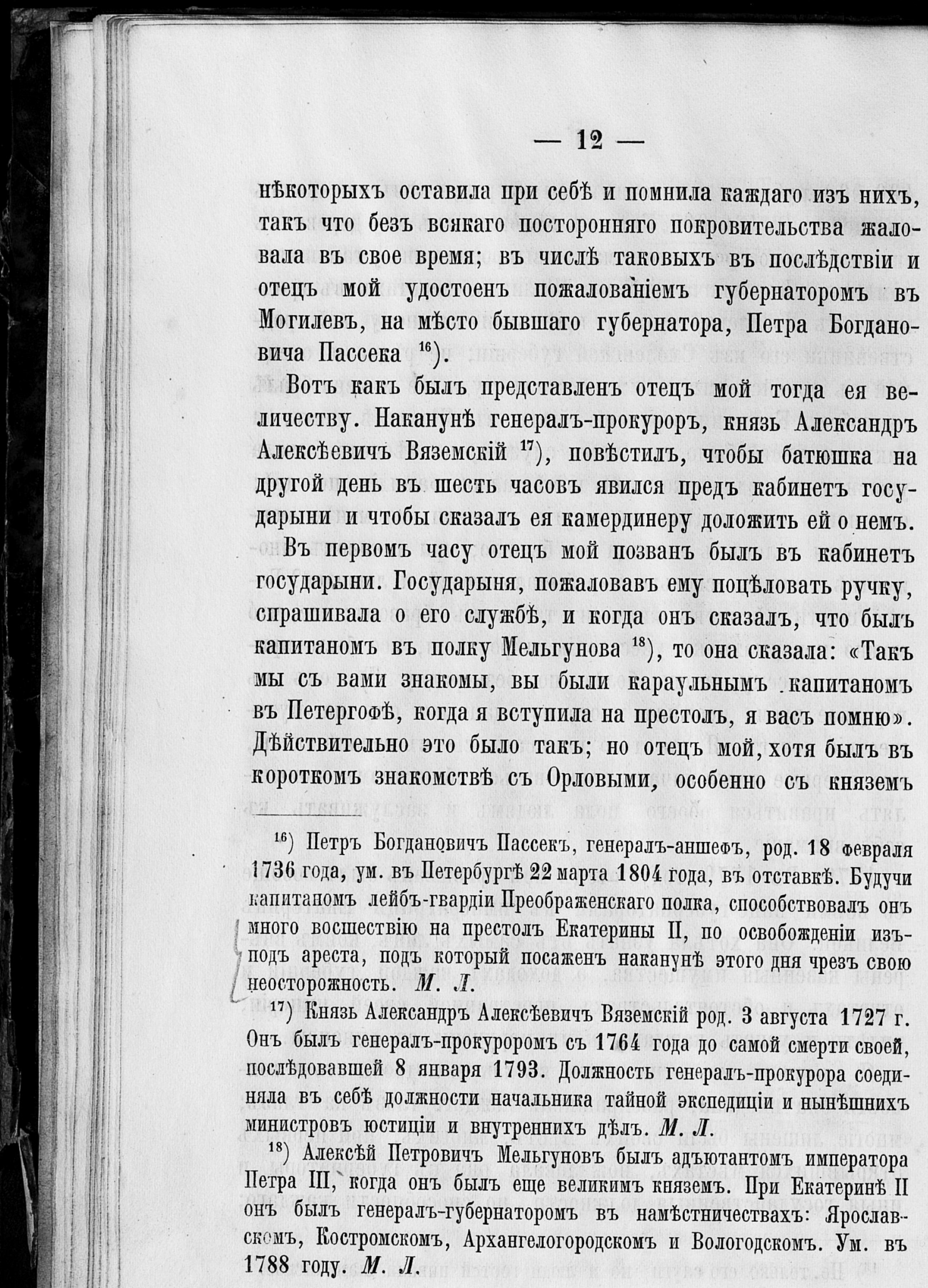


Григорьемъ Григорьевичещъ ${ }^{19}$ ), съ воторымъ былъ въ одно время адъютантомъ у графа Петра Ивановича Шувалова ${ }^{20}$ ), но по его твердымъ правилащъ ему не открывали заговора; начальствовавшичи же въ Петергофъ при императорь Петрж III, державшими уже сторону императрицы, никакого особаго наставленія караульнымъ дано не было, а потому ему вовсе заговоръ не былъ извжстенъ. Потомъ государыня разспрашивала 0 доходахъ Могилевской губерніи; отецъ мой на многія подробности государынъ донесъ, что не имъетъ въьрной памяти и, чтобы не сказать ложно, то просить позволенія справиться съ своею памятною книжкою, готорая для сего нарочно была заготовлена и, которую вынувъ изъ ґармана, тотчасъ далъ отчеты на вопросы государыни со всуми подробностями. Императрица сказала: “Позвольте взглянуть на вашу память, готорая гораздо лучше, нежели бы вы мнъ отвӝчали словами»; долго разсматривала книжку, въ которой были помёщены все въдомости и отчеты, со всъии обстоятельствами и съ замйчаніями, сдйланными собственною рукою моего отца, потомъ сказала: «Можете ли вы меня ею подарить? Я каждому вище-губернатору прикажу имбть таковую». Между прочимъ говорила еще: аОтчего ваша губернія въ прошлошь году такую претерпъ̌вала въ соли нужду, что жители принуждены были вымачивать

19) Кінязь Григорій Григорьевичъ Орлов'ь, генералъ-фельдцейгмейстеръ, старшій изъ знаменитыхъ братьевъ Орловыхъ, род. 6 октября 1734 г., ум. въ Москвъ 13 апрьљля 1783 г. Въ 1762 году онъ былъ не болье каґъ цейгмейстеромъ артиллеріи до самаго восшествія на престолъ Екатерины II. Князь Орловъ особенно памятенъ своими дъйствіями при прегращеніи въ Мосгвв чумы въ 1771 году; черезъ годъ посл'ь того оставилъ онъ цворъ, путешествоваль за границей и постоянное пребываніе свое основадъ въ Москв ъ. $\boldsymbol{M}$. JI.

$\left.{ }^{20}\right)$ Грабъ Петръ Ивановичъ Шуваловъ, Фельдмаршаль, род. 1711 г., ум. 4 января 1762 г., родоначальниғъ всъхъ нынъ̆шнихъ графовъ ШІуваловыхъ. $M$. II. 


\section{$-14-$}

сельди и ть̌мъ солить свою пищу?» $\left.{ }^{21}\right)$ - (Государыня, отвњัчаль мой отецъ,-сіе донесено вамъ было ложно, свидттель этому сія же книжка, въ которой изволите вы усмотрьть, что великое количество соли оть каждаго года оставалось

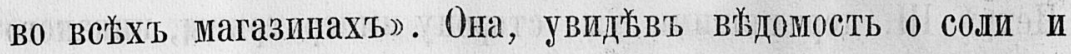
увърившись въ справедливости слов'ь моего отца, сказала: «Я скажу вашему намьстнику ${ }^{22}$ ), что онъ имъетъ въ васъ человъ̌ка, который справедливымъ удостовърительнымъ образомь отстаиваеть его», что́ на другой же день и исполнила, сказавъ 0 томь брату его, графу Ивану Григорьевичу Чернышеву $\left.{ }^{23}\right)^{24}$ ). Еще спросила: “Отиего въ Бешенковской таможнж такь мало соирается пошлинь? \& знаг, что всъ эти сборщики таможень очень дъълтся со мною доходани и вовсе ихъ унять. нбтт средствь, однакожь надобно знать и совъьст, а Бешенковспіе таможенные, кажется, вовсе ея не имьоютъ.»-«Государыня, отвъчаль мой отецъ:-за че-

21) Cie было выдумано непріятелями бывшаго тогда намъ̌стика, графа Захара Григорьевича Чернышева.

22) Графь Захарь Грпгорьевичь Чернышевъ, Фельдаршаль и сь 1782 по 1784 годъ главнокомандующій въ Москвж, род. 18 марта 1722 года, ум. 29 августа 1784 г. 0нъ былъ третій сынъ деньщиға и любимца Петра I, Григорія Петровича Чернышева, отъ брака его съ Авдотьей Ивановной Ржевской. М. J.

23) При этомъ отецъ мой доложиль, что какь въ Польш' соль была гораздо дороже, и жители гъ тому привыкли, то казна имъла бы великое приращеніе въ доходахъ, еслибы пустить соль въ продажу по прежнимъ цтьнамь: жители бы повинность сію приняли безъ

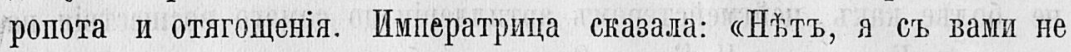
согласна, пусть соль, столь необходимая для жизни и сохраненія здоровья, будеть даже сь убыткоуь газнъ, пежели наложить подать на народъ!)

24) Гражъ Иванъ Григорьевичь Чернышевъ, брать предыдущаго, былъ пожалованъ, при восшествіи на престоль Павла I, генералъфельдмаршаломь по флоту п президентом'ь адмиралтействъ-коллегіи. Род. 24 ноября 1726 г., ум. 12 февраля 1797 г. M. $\mathbb{A}$. 
стность ихъ не ручаюсь, и она впрочемъ не подлежить

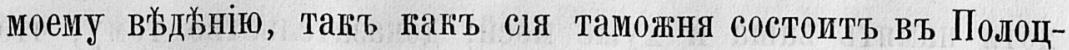
кой губерніи; но отговорки ихъ отчасти служатъ къ ихь оправданію ${ }^{25}$ ), а именно Евреи, въ рукахъ которыхъ въ Бълоруссіи почти весь торгъ, ъздять въ Ригу не для покупки товаровъ (хотя отчасти и покупають тамь товары, привовимые чрезъ Балтійское море, какь-то: сахарь, кофе, пряности, вины, англійское пиво и прочія, но главнбйшій товаръ покупають на ярмаркахъ лейпцигской, Франкфуртской и кенигсбергской) -они жздятъ въ Ригу для погупки абштуховъ отъ разныхъ тамошнихъ кушцовъ. Дьло воть въ чемъ: закономь постановлено, что если товаръ гуплень въ Ригж, за который уже пошлины заплачены, т0, за подписью свидйтельства или абштуховь рижскихъ кушцовь, съ тьхъ товаровъ пошлинъ въ таможняхъ не брать. Еврей, пріћхавъ въ Ригу, ожидаеть оть своихь прикащиковъ изв'ьщенія, сколько какого товара ими закуплено, а потомь стакнувшись сь извьстнымь ему рижскимь кушцомь и получив' за подписаніеюь абштухъ, вдеть почти съ пустою баркою по Двинге, и ночью причаливь кь польскому берегу, гдь ожидаеть его купленный на упомянутыхъ ярмаркахъ товаръ, нагружаеть оную и ьдеть мимо Бешенковской таможни, псдъ видомъ, что везеть товаръ изъ Риги; показываеть абштухъ, таможенные свидытельствують и видя, что весь товарь описань точно, не имгють права останавливать и пропускаютъ» . “Воть большіе искусники вапи Бешенковскіе таможенные, сказала имератрица:-они не уступаютъ тонкости жидовъ, и я не вижу средства пресь̌чь такое злоупотребленіе ». Продертавъ же отща моего наединьь болье двухь часовь, пожаловала ручку и сказала: “Я бы

25) Когда Бълоруссія взята была оть Польши, то оть Риги граница была по Двинь до Островны, ниже Бешенковичъ версть съ пятьдесять 
желала, чтобы всъхъ нашла тақовыхъ вице-губернаторовъ, хотя память ваша и хуже моей; доказательство топу, что я васъ вспопнила, и будьте увърены и впредь о васъ буду помнить. )

1780. Въ сльъдующій 1780 годъ императрица предприняла путешествіе въ новопріобржтенный грай, въ Бљлорусскія губерніи, и въ Могилевъ назначено было свиданіе съ римскимь имшераторомъ Іосифомъ II $\left.{ }^{26}\right)$. Для принятія высокихъ путешественниговъ дњлали большія приготовленія; намьстникъ, фельдмаршаль графъ Захаръ Григорьевичь Чернышевъ, не щадиль трудовъ, чтобы представить ввърренныя ему Полодкую и Могилевскую губерніи въ лучшемъ устройствђ, и действительно онъ были въ самомъ цвътуущеиъ состояніи, каґъ по наружности, такъ и по внутренности, каґъ по исполнительной, такъ и по судебной и х0зяйственной части. Јюди, иит собранные, были отличной нравственности, свъ̌дущіе въ дъълахъ и дйнтельные; словонъ, сіи губерніи могли быть образцомъ для всей Россіи.

Вначаль жители не могли быть довольны новымъ правительствомъ, и, правду сказать, граф' принялся круто, въ тощъ краһ̌, гдъ̌ была совершенная анархія: паны поступали съ своими крестьянами по произволу, даже и въ жизни ихъ были властны; ґоторый изъ нихъ былъ богаче,

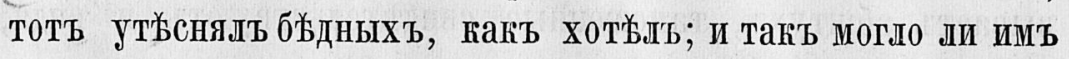
быть пріятно, когда на всяғомь шагу останавливали ихъ въ буйныхъ дерзостяхъ? Дьъланіе же дорог'ъ произвело общій ропотъ. За то дороги были не только отъ столицъ, но и ко всъмъ смежнымъ губерніямъ и уъъдамъ таковы, какимъ во всей имшеріи не было подобныхъ; шировія, прямыя дороги ведены были чрезъ льса, горы и буераки, по обжимъ

26) Іосифъ II, императоръ гернанскій, сынъ императора Франциска I-го п Маріи Теревіи, род. 2 (13) марта 1741 г., царствовалъ съ 7 (18) августа 1765 г., умерь 9 (20) Февраля 1790 г. M. I. 
- сторонаит вырыты были канавы и обсажены въ два ряда березками, горы были скопаны, гати были сдъланы по непроходимымъ зыбямъ и болотамъ; мосты прочные, переправы черезъ рьки безопасныя; на почтовыхъ станціяхъ выстроены были домики и снабжены простыми, но достаточными мебелями, тағъ что каждый пробзжающій находиль не только спогойный ночлегъ, но и все нужное. Графъ склониль помъщиковъ тйхт селеній, гдъ̌ станціи были учреждены, взять въ свое спотрьніе не только сіи домики, но и почтовыхъ лопадей и почтальйоновъ, одътыхъ пристойно по образцу, каюъ въ Пруссіи ${ }^{27}$ ); казна по сходнымъ цъънамъ платила за то содержателямъ, такъ что они имъљли небольшой доходъ.

Въ городахъ, какъ губернскихъ, такъ и уь̌здныхъ, присутственныя мъста выстроены были каменныя въ два этажа, съ приличнымъ расположеніемъ и архитектурою; дома для государева намъ̌стника съ большою залою, въ гоей былъ поставленъ тронъ ${ }^{28}$ ) и все дворянство внъщалось для выборовъ; дома для губернатора, вице-губернатора и предсъддателей палатъ, а въ уъздахъ для городничихъ. Въ посльљдствіи, гогда все сіе учредилось, сей государственный челов'ььъ всьими былъ обожаемъ.

27) Гр. З. Г. Чернышевъ долго находился въ Пруссіи во время семильетней войны. Здъ̌сь читатели припомнятъ правителя ганцеляріи гр. Чернышева во время его намъ̌стничества въ Бълоруссіи,С. И. Гамаль̌ю, и сегретаря его $\theta$. II. Ключарева, см. Лонгинова: Новиковъ и Московскіе Мартинисты, М. 1867, стр. 163 и далье.-Подобныя же дороги устроены были впосль'̆ствіи и во многихъ другихъ краяхъ Россіи; деревья по богамъ служать спасеніемъ во время зимнихъ мятелей, но по недостатку стоковъ воды, Пушгинъ называлъ эти дороги ящиками для грязи.

28) Подобные троны были и не въ одномъ БЪылорусскомъ намъстничествъ. На нихъ въ торжественныхъ случаяхъ садились намъзетники, что̀ подало поводъ Державину гъ стиханъ: «На пышныхъ парточныхъ престолахъ, сидятъ миттрныте цари) 
Ћакъ императрица назначила для своего прео́ыванія въ Могилевъ семь дней, то чтобы со стороны увеселеній было чьмъ ванять ее и дворъ, графъ выписалъ изъ Петербурга придворную италіянскую оперу, а для конщертовъ придворную музыку и лучшихъ артистовъ, въ числь которыхъ по тогдашнему времени славилась извљстная пьвица Бонафика; для праздниковъ же построилъ на свое иждивеніе театръ и пространную залу, по плану и содййствію славнаго архитектора Бригонщія.

Собранъ былъ корпусъ войскъ изъ лучшихъ полковъ: перваго кирасирскаго, двухъ гусарскихъ, одного драгунскаго, пяти пъхотныхъ, пятидесяти орудій полевой артиллеріи и двухъ полғовъ Донскихъ газаковъ, подъ командою генералъ-поручика Степана Матвеевича Ржевскаго ${ }^{29}$ ), пзвысстнаго по тактическимъ познаніямь и нъъоторымъ военнымъ сочиненіямъ, которыхъ, однакожь, въ печать не выдалъ; имъ приготовлены были для императора маневры.

За мъъсяцъ до прибытія государыни, съъхались иностранные министры, часть двора, множество иностранцевъ, а особливо знатныхъ и богатыхъ польскихъ вельможныхъ пановъ; тогда Могилевъ уподоблялся болъе многолюдному, столичному, нежели губернскому городу. Безпрестанные были праздники, балы и карточная игра, каковой, конечно, прежде въ Россіи не бывало, да и сомнительно, было ли и посль; графъ Сапъга ${ }^{30}$ ) проиграпъ тогда все свое знатное имьніе $\left.{ }^{31}\right)$.

29) Степанъ Матвеевичъ Ржевскій, гепералъ-поручикъ, род. 17 деғабря 1732 г., ум. 1782 г. M. I.

зо) Полагаемъ, что здъ̌сь говорится о сынъ граша Петра Ивановича Сапъги, бывшемъ женихомъ княжны Менщиковой, до назначенія ея невъстой императора Петра II. Грабъ Петръ Ивановичъ Сапь̌га женился потомъ на графинъ Собьљ Карловнъ Скавронской, родной племянницъ Екатерины I, и былъ гамергеромъ Русскаго двора. $M$. dI. 31) Случилось въ то время странное видынніе бывшему тогда губер- 
Наконецъ государыня, чрезъ Псковскую и Полоцкую губерніп, прибыла къ границь Могилевской, гдъ отецъ мой встрбтиль ее, а губернаторъ посланъ быль встръчать императора Іосифа II. подъ именешь графа Фалкенштейна ьхавшаго со стороны Галиціи. Императрица пожаловала отцу моему поцъзловать ручку и сказала: “Еслибы я сама не виды̆ыа таковаго устройства въ Бљлоруссіи, то никому бы не повърилақ а доро́ги ваши какъ сады.» Передъ въъздомъ въ Могилевъ императрица ночевала въ ІІкловъ, гдъъ была уго-

натору Петру Богдановичу Пассеку. Онъ былъ страстный игрогъ. Въ одну ночь, проигравъ тысячъ съ десять, сидъъль около трехъ часовъ у гарточнаго стола и вздремнулъ, какъ вдругъ, очнувшись, сказалъ: Attendez; приснился мнъ съзой старикъ съ бородою, который говоритъ: “Пассекъ, пользуйся, ставь на тройку 3000 , она тебъ выиграетъ сонига, загни пароли, она опять тебъ выиграетъ соника, загни сетелева, и еще она выиграетъ соника.) Ба, ца вотъ и тройка лежитъ на полу; идетъ 3000 s. И точно она сряду выиграла три раза. Но сіе видъ̆ніе тъ̌мъ не кончйлось. Пассекъ былъ ль̌нивый человъ̌ъъ. Грабъ Захаръ Григорьевичъ требовалъ дъ̆ятельности, а потому Пассекъ безпрестанно получалъ отъ него выговоры и взысканія. Въ одинъ день получаетъ онъ пвъ Полоцка отъ графа строгій выговорт; на тоть разъ былъ у него мой отецъ и многіе другіе его пріятели изъ тамошнихъ чиновниковъ. «НБутъ, братцы, говоритъ онъ, я рб̆шился идти въ отставку, долго ли терпьоть тағія неудовольствія. Да и старикъ мой, который заставилъ меня выиграть 21.000, сегодня приснился мнъ̆ и сказаль: «Полно, Пассекъ, грустить, поди въ отставку, тебя отставятъ, но не пройдеть трехъ мъъсяцев'ь, какъ пожалують тебя' сенатором'ъ, а ровно чрезъ годъь оть сего дня главнокомандующій в'ь Москвґ, князь В. М. Долгоругій умретъ, на его мъ̌сть будетъ графъ Захаръ Григорьевичъ; тебя же пожалуютъ на мйсто посль̈дняго.» 0тецъ мой записалъ сей день, и онъ точь-вт-точь въ годъ сбылся. Нужно замъ̌тить, что ғнязь Долгорукій лтттами былт гораздо моложе графа Чернышева и былъ здоровъ. Л. Э.

(Князь Василій Михайловичъ Долгоругій-Крымскій, генералъ-аншешъ и съ 1780 по 1782 годъ главногомандующій въ Москвъ. Родился 1 іюля 1722 г., умерт 30 января 1782 года). $M . \AA$. 
щаема бывшимъ ея фаворитомъ Зоричещъ, а на обратномъ пути объщала пробыть въ Шкловъ однъь сутки.

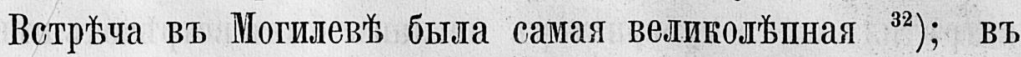
трехъ верстахъ, построены были тріумфальныя ворота прекрасньйшей архитектуры, между ними и городомь поставлены были войска, а пг другой стороне народъ и м'ъщанство съ ихъ цеховыми значтами. У самыхъ тріумфальныхъ воротъ встрьтиль государыню намьстникъ рафъ Захарь Григорьевичь Чернышевъ съ чиновниками губерніи, и дворянствомт съ ихъ предводителями, верхами; у городскихъ воротъ-прибывшій нағанунъ фельдмаршалт, графт Петръ Александровичъ Румянщевъ-Задунайскій ${ }^{33}$ ), свъттль̆шій князь Тригорій Александровичъ Потемкинт и всъь бывшіе туть генералы; передъ каретою императрицы ьхалт эскадронъ кирасиръ. Въ сопровожденіи всъхъ вышеупомянутыхъ особъ, при грошь' пушекъ и звонь голоколовъ, императрица прибыла прямо къ собору, гдъз встрььчена была съ крестомъ и св. водою преосвященнынъ Георгіеит, архіепископомъ могилевскимъ $\left.{ }^{34}\right)$; приложась къ образамъ и отслуживъ благодарный молебенъ, она отправилась въ домъ намъстника, гдъ имъла свое пребываніе. Тамъ встрљчена была римско-католическимъ архіепископомъ Сестренцеви-

32) Въъъздъ Екатерины въ Могилевъ происходилъ 24 мая 1780 г., она осталась тамъ до 30 мая. $M$. J.

33) Грашь Петръ Александровичь Румянцевъ-Заджнайскій, фельдмаршаль, родился 1725 г., ум. 8 декабря 1796 г. Онъ былъ сынъ любимца и деньщика Петра I, Александра Ивановича, отъ брака его съ графинею Марьею Андреевною Матвеевою, внугою знаменитаго болрина Матвеева, на смерть которой (4 мая 1788 г.) Державинъ написаль одну ивъ превосходнййшихъ своихъ одъ. $M$. $Л$.

з4) Георгій Ћһнисскій, архіепископъ бълорусстій, родился въ Нъжинь 20 ноября 1717 г., умеръ въ Могилевъ 13 февраля $179 \ddot{~ г . ~}$ Сочиненія его изданы въ двухт частяхъ (Спб. 183з г.), и разборь ихъ написанъ Пушкинымъ (Соч. Пушкина. Изд. Анненкова Т. Ү. стр. らૅ4). M. I. 
чещъ ${ }^{33}$ ) съ духовенствощъ, и супругою наубетниға, статсъдамою, графинею Анною Родіоновною Чернышевою, съ дамами $\left.{ }^{36}\right)$.

На другой день императрица осматривала присутственныя мъста, и посль⿱ представлялись ей чиновники губерніи и дворянство. Въ тоть же день къ объду прибылъ и императорь, въ сопровожденіи своего генераль-адъютанта и фаворита Когцейна ${ }^{37}$ ). Вечеромь представлялись всъ дашы, посл'ъ чего при дворь быль балъ.

Не знаю, справедливо ли, но распространился слухъ, что императрица поввала къ себъ фельдмаршала, графа Петра Алегсандровича, и говорила ему о планъ союза съ Австріею. Надобно знать, что съ самаго вступленія на престоль императрицы дворы Россійскій и Прусскій связаны были тъснымъ союзомъ; фельдмаршалъ страстный быль приверженъ къ Пруссіи; въ Семильтнюю войну онъ уже извъстенъ быль взятіешь Кольберга ${ }^{38}$ ), а потощъ быль съ вспомогательнымъ корпусомъ, въ конць царствованія Петра

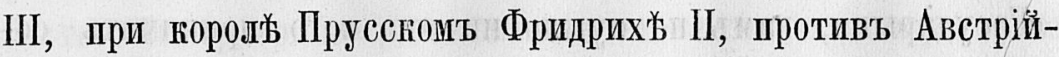
цевъ; при восшествіи же на престоль Екатерины II, оставался зрителень побъдь Фридриха Великаго. Съ того времени фельдмаршаль быль обворожень его воинскимь и

${ }^{35}$ ) Сестренцевичъ-Богушъ быль потомъ митрополитомъ римско-католическихъ церквей въ Россіи. $\boldsymbol{M .}$. .

36) Графиня Анна Родіоновна Чернышева, урожденная Ведель, род. 1744 г., ум. 9 іюня 1830 г. Сестра ея Марія Родіоновна была замужемъ за графомъ Петромъ Ивановичемъ Панинымъ (см. выше стр. ๖). 0бъ сестры остались сиротами посль отца своего, васлуженнаго генерала, и взяты были во Фрейлины имшератрицей Елисаветой. $\boldsymbol{M}$. II.

з7) 0ный Когцейнъ, на третій день пріъзда въ Могилевъ, ночью хотьввъ утолить жажду, схватиль графинъ воды, который лопнуль; мелкіе части стекла връзались въ руку его, отъ чего сд'ълался антоновъ огонь, и на другой день онъ умеръ. Погребли его уже по отъъздъ двора съ подобающею по чину его военною почестію.

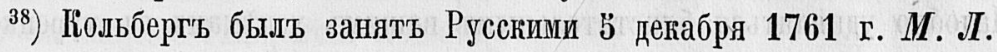


государственнымъ геніемъ; въ посльдсстіи два раза быль въ Пруссіи съ насльдникомь, для женитьбы его, сперва на

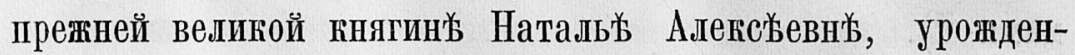
ной принцессь дармштадтской ${ }^{39}$ ), а потощъ на нынушшней

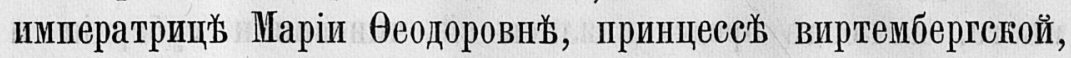
да и сама императрица Екатерина Алексьевна была принцесса цербстская, родственница короля Прусскаго Фридриха II. Ћороль чрезвычайно уважаль фельдмаршала, и онь со всъми славными прусскими генералами быль въ короткомъ знакомствь, восхищался прусскою арміею, понечно тогда

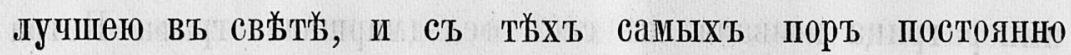
твердо оба двора хранили союзъ; новый же союзъ съ Австріею, по природъ враждебною Пруссіи, предложенъ быль княземъ Потемғинымъ, личнымъ непріятелемъ, по нуьготорымъ причинамъ, съ фельдмаршаломъ $\left.{ }^{40}\right)$. Натурально, чт0 онъ опровергаль этоть союзь, но государыня утверждала, «что союљъ сей касательно турецкой войны выгоденъ, и князь Потемкинъ то совътуеть». Фельдмаршаль сказаль: жГосударыня, вамъ не нужно ни оть кого принимать со-

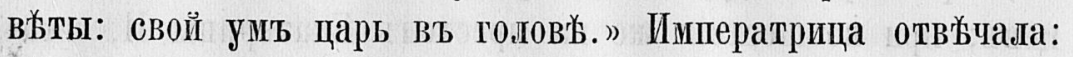
“Правда, но есть и другая русская пословица, не менье справедливая: одинь умъ хорошо, а два лучше.» Неспотря на представленіе фельдмаршала, союзь съ Австріею быль заключень лично между двумя монархами “).

${ }^{39}$ ) Великая княгиня Наталья Алексъевна, первая супруга цесаревича Павла Петровича, род. 14 іюня 1755 г., вышла замужъ 29 сентября 1773, ум. 16 апрьля 1776 г. Она была родная тетка императрищы Елисаветы Алексъевны. $\boldsymbol{M}$. $\boldsymbol{l}$.

40) Графъ Румянщевъ не мало способствоваль возвышенію Потемкина въ первуг турецкую войну, но потомъ испыталъ отъ него непріятности. $\boldsymbol{M}$. $\boldsymbol{I}$.

41) Императоръ, увнавъ, что фельдмаршаль не былъ къ нему въ добромъ расположеніи, разговаривая съ нимъ однажды, сказалъ: «надобно удивляться блистательнымъ вашимь успгххамъ въ турецкой 
Въ теченіи нб̌сколькихъ дней, по утрамъ производились маневры въ присутствіи императора, а по вечерамъ продолжались праздники. На четвертый день пребыванія двора, бывши во дворц'ь, графъ Захаръ Григорьевичъ говорилъ князю Потемкину, чрезъ котораго текли всъ милости и съ которымъ онъ былъ тогда въ шріятномъ обхожденіи, что очень бы ену желалось, если бы государыня наградила достойнаго пастыря преосвященнаго Георгія панагіею; князь съ удовольствіемъ взялся доложить объ этомъ императриць и тогда же пошель въ кабинетъ ея величества, откуда вышелъ чрезъ короткое время и отдавая графу панагію, сказалъ: «Иввольте отвести сами желаемое вами награжденіе

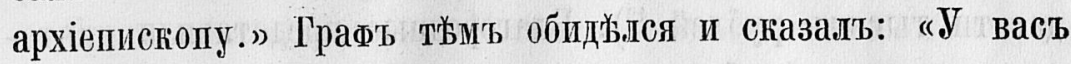
есть на то адъютанты, а я уже старт для разсылокъ».

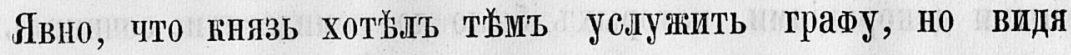
его гордый отвйтъ, приказаль при немъ своему адъютанту отвезти панагію къ архіерею, а самъ пошель къ государынъ и пожаловался за сдъ̌ланную ему при всъхъ грубость. Императрица разгнъьвалась и съ тьхт порь уже обращалась съ графожъ холодно. Щедрыя награжденія орденами, чинами и подарками, какія были приготовлены чи-

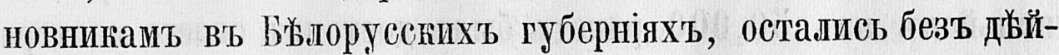
ствія. Свъттльйшій князь въ тоть же день отправился. Кажется, что графъ напрасно погорячился ил тьй самымъ лишилъ себя и подчиненныхъ своихъ многихъ ожидаемыхъ милостей.

войнй, что вы всегда продовольствовали армію въ таґъ худо населенной венлъ, какъ Молдавія и Валахія; но что вы били Турокъ, то это сволочь (c'est de la canaille).) Граф'ь такъ былъ не доволенъ таковымъ комплиментомь, что, въ посльъдующей турецкой войнъ, нигакой диверсіи не дъ̌ълаль въ пользу Австрійцевъ, и когда получаль извъ̌стія, что Австрійцы были разбиты, то съ удовольствіенъ говаривалъ: “C'est de la canaille qui bat les troupes belles et regulières de Sa Majesté l'Empereur Romain!) 
Въ пятый день заложена была церковь во имя св. Іосифа, для зданія которой императрица и император'ь назначили значительныя суммы; при этомъ императрица, посль̆ пол安нопреклоненной молитвы, вштсто того, чтобы позволить себя приподнять графу, обернулась къ губернатору Пассеку и, подавъ ему руку, сказала: «Петръ Богдановичъ, пособите мнъ встать.» Посль того ея величество уже не была, какъ до сего, ни на кагомъ угощеніи.

Въ седьмой день по утру императрица отправилась съ императоромъ Іосифомъ въ Шкловъ. Зоричъ къ пріӝзду ея построиль преогромный домъ, богато убранный, выписаль ивъ Саксоніи фарфоровый сервивъ, стоившій болъе шестидесяти тысячъ рублей ${ }^{42}$ ). Благородные представили пантомиму на театрб,, бывшемъ въ томъ же домъ, съ чрезвычайными декораціями, которыхъ было до семидесяти; сочиниль оную, а также и музыку, гостюмы и декораціи баронъ Ванжура, отставной ротмистръ австрійской службы; императоръ его тотчас́ь узналъ и объявиль ему сожальнніе, что онъ оставпль его службу. Посль ужина быль сожженъ фейерверкъ, дъъланный ньссколько мисяцевъ артилеріи генералъ-майоромъ Петромъ Ивановичемъ Мелиссино ${ }^{43}$ ); павильйонъ изъ ๖̌0,000 ракеть быль достоинъ своего мастера и стоилъ чрезвычайно дорого.

42) Пћловскій купецъ, Еврей Нотка, былъ посланъ отъ Зорича въ Дрезденъ для покупки того фарфора. За прововъ онаго чрезъ Пруссію у въ.ьзда въ границы сего королевства взята сь него пошлина, а потомъ также и при вы'здљь'. Нотка письменно жаловался королю, что несправедливо съ него взята вдвойне пошлина за прововимый ииъ

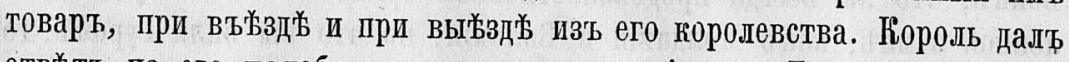
отвъть на его жалобу въ такихъ выраженіяхь: «Господинъ шкловскій купецъ Нотка! Справедливо взята сь васъ за товаръ пошлина, положенная законами; также справедливо и то, что при выъ̌зде́ взята таковая же; ибо еслибы вы не захоть̌ли платить пошлину два раза, то могли бы купить фарфоръ на моей берлинской фабрик官.

43) Петрь Ивановичь Мелиссино, генераль отъ артиллеріи, родился 
На другой день императрица отправилась въ С.-Петербургъ, чрезъ Смошенскъ и Новгородъ, а император'ь чрезъ Москву.

По отбытіи императрицы былъ объдъ у архіерея Георгія, гдъ̌ графъ Захарь Григорьевичъ изъявиль свое огорченіе. Посль нъ̌сколькихъ рюмокъ вина, и нъсколько бывъ нетрезвъ, онъ сказалъ: «Ну, друзья мои, я виновать, что никт0 изъ васъ не награжденъ; признаюсь, не кстати разгорячился; ну вотьь по крайней мърж жалованье государыни

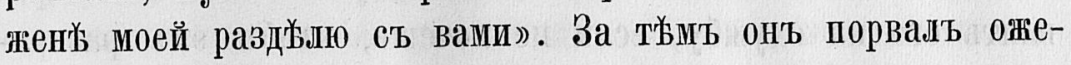
релье жемчужное у сидъвшей возль его графини, готорое разсыпалось и готорое послгъ подобрали.

Чрезъ нъсколько дней Могилевъ изъ многолюднаго города сдґ̌̈лался пустой и принялъ свой видъ. Въ исходъ̆ сего года Пассекъ вышелъ в'ъ отставюу, а отець мой на его мъсто пожалованъ губернаторомъ.

1781. Въ 1781 году насльъдникъ престола, великій князь Павелъ Петровичъ съ великою книгинею продзжалъ чрезъ Могилевъ въ чужіе краи ${ }^{44}$ ). Отецъ мой провожаль его чрезъ всю губернію. Графъ Захаръ Григорьевичъ Чернышевъ въ Чечерскъ, мъьстечкъ̌, принадлежавшемъ ему, угостиль великаго князя велиюоль̌ыно. Былъ благородный театръ, была дана опера: Новое Семейство ${ }^{45}$ ), для сего случая сочиненная бывшимъ тогда полковникомь $\mathbf{C}$. $\mathbf{K}$. Вязмитиновымъ,

176 г., ум. 26 декабря 1797 года. Старшій братъ его Иванъ Ивановичъ (род. 1718 г., ущ. 23 марта 179 ӛ г.) былъ съ 1771 года до смерти своей кураторомъ Московскаго университета. Отецъ ихъ былъ лекарь, пріъхавшій въ Россію при Петрй Великомъ. М..I.

44) Путешествіе великаго ғнязя съ супругой за границу процолжалось 14 нъсяцевъ. Они выъххали изъ Царскаго Села 19 сентября 1781 г. и пось̌тили Въ̌ну, Венецію, Римъ, Неаполь, Швейцарію, Парижъ, Голландію. М. Л.

45) 0пера эта напечатана тогда же (II. въ Универ. тип. 1781 г.). Сюжетъ ея взять изъ Русской простонародной жизни. $M$. JI. 
а музыка оной-графскимъ адъютантомъ г. Фрейлихомъ; потомъ Францувская комедія Anglomanie; спектағль кончился прологощъ, играннымъ дъътьми и сочиненнымъ графскимъ секретарещъ Өедоромъ Петровичемъ Ключаревымъ $\left.{ }^{46}\right)$. Я и старшая сестра моя играли въ оперъ. По огончаніи театра, актеры представлены были ихъ высочествамъ. Великій князь спросиль отца моего, записанъ ли я въ службу? Какъ онъ отвб̌чалъ, что записанъ въ Преображенскомъ полку сержантомъ,-великій князь сказалъ: “Шожалуста не спґши отправйять его на службб, если не хочешь, чтоб̆ъ онъ развратился». Посль' ужина сожженъ фейерверкъ. На другой день ихъ высочества отправились въ Гочель, мвстечко, принадлежавшее фельдмаршалу графу Петру Александровичу Румянцову-Задунайскому, гдњ были им'ь угощаемы, и продолжали далье путь свой.

Въ семъ году графъ Захаръ Тригорьевичъ Чернышевъ пожалованъ былъ главнокомандующиюъ въ Москву, а Петръ Богдановичъ Пассекъ на мъъсто его въ Могилевъ ${ }^{47}$ ).

1782. Въ 1782 году свъ̌тыйшіпій князь Потемкинъ, пр0ъзжая чрезъ Могилевъ, объщаль отцу моему взять меня къ себъ въ адъютанты, и въ сенъ году пріобрљ̆ы онъ полуостровъ Крымъ, готорый названъ Таврическою губерніею ${ }^{48}$ ). Свътльйшій князь пожаловань генераль-губернаторомь, гакъ въ оной губерніи, таюъ въ Новороссійской и Херсонской.

46) Өедорь Петровичь Ключаревъ быль посль̆дователь пистической школы Новикова. Онъ быль въ посльъдствіи московскимъ почтъ-директоромь. Изъ сочиненій его напечатана отдъльно трагедія въ пяти дъйствіяхъ, въ стихахъ: Владимірг Великій (У. въ Унив. тип. 1779 г.). При графъ Захаръ Григорьевичъ Чернышевъ служиль также въ Бълоруссіи, а потомъ въ Москвъ, извбьстный мистикъ Семенъ Ивановичъ Гамалья, и покровительствомъ графа пользовались служившіе въ Москвъ посл'ъдователи Новикова, Иванъ Владиміровичъ Лопухинъ и Иванъ Петровичъ Тургеневъ. $\boldsymbol{M}$. $\boldsymbol{I}$.

47) Тутьь есть небольшая неточность; әто пропсходило въ февральь 1782 года. M. II. 
Вотъ происшествіе, случивштеся во вреия прољзда его свйтлости. Со времени случая Зорича они между собою были непріятели; хотя князь и не имьљь къ Зоричу ненависти, но тотъ всегда думалъ, что онъ къ нему не благоволитъ; чтобы доказать противное, свъ̌тљъйшій князь остается въ Пॉковъ на цъъый день. Одинъ Еврей проспль позволенія переговорить съ княземъ наединь'; князь, не ожидая ничего важнаго, не хоть⿻ыљ было его ґъ себ̆ъ допустить, но каґъ тоть Еврей безотвязно просиль 0 томъ, то князь и велжљљ ввести его къ себж въ особливую гомнату. Еврей показываетъ сторублевую ассигнацію: “Видите ли, ваша свътлость, что она фальшивая?» Князь долго разспатриваль и не находиль ничего: такъ она хорошо была поддызана, подпись сенаторовъ и разными чернилами, казалось, не могла быть подвергнута ни мальйшему сомнънію. “Ну что же тутъ, покажи", сказалъ князь. Тогда ґ̊идъ показываетъ, что виъсто ассигнація напечатано ассигиація. $\left.{ }^{49}\right)$ - (Гдьь ты ее взялъ?»-Если вашей свъътости угодно, я вант чрезъ полчаса принесу нъсколько тысячъ.- - Кто же ихъ дъълаетъ или выпусгае'гъ?» спросиль князь.- “Камердинер’ь графа Зановича и карлы Зоричевы.» Князь даль Еврею тысячу руббей и приказалъ, чтобъ онъ промьнялъ ихъ на фальшивыя ассигнаціи и привезъ бы епу на другой день въ мъстечко его

48) Крымъ присоединенъ къ Россіи 8 апрььля 1783. Авторъ записокъ нъскольго ошибается въ этошъ чъ̌сть, относя это событіе къ 1782 г.,

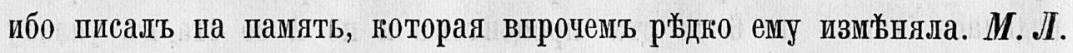

49) Этимъ происшествіемъ доказалась легкость въ поддњ̌љкь ассигнацій, что́ и было одною изъ причинъ, по которой императрица перемънила пхъ. Впослъдствіи уже не сенаторы подписывали новыя, а чиновники Государственнаго Банка; прежнія были только во 100 , въ 50 и въ 25 руб̆лей; пъ нимъ прибавлены новыя въ 10 рублей (красныя) и въ Цૅ рублей (синія). Въ конщй царствованія Алегсандра I-го тагъ умножилось фальшивыхъ ассигнацій, что ихъ снова перемгьнили и сдълали другой формы. 
Дубровну, недавно имъ купленное, отъ ІІклова по Смоленской дорогъ верстахъ в'ъ семидесяти.

Отпустивъ Еврея, князь притворился нездоровымъ и въ тотъ же день, до выздоровленія, возвратился въ Дубровну

Ћъ перемънъ ассигнацій императрицею былъ еще поводомъ двадцатиль̌тній Банкъ съ 20-ю милліонами для дворянства и съ 13-ю милліонами для купечества, подъ залогъ имъній устроенный; ревизская душа принималась во сто руб̆лей, плата процентовъ со ста по пяти, да въ уплату по три,-в'ь двадцать л'ъттъ долгъ долженъ былъ ваплатиться. Поэтому, кто только успьљ, то и воспольвовался этимъ. Люди благоразумные, сдЊлавъ заемъ, употребили сумиы для заплаты долговъ частнымъ людямъ или для нб̆которыхъ оборотовъ; но бо̀льшая часть употребила для прихотей и роскоши, которая съ ть̌хъ поръ много увеличилась и для нравственности была тибельна; отъ нея цворянсгво вошло въ долги и видино стало бъ̆днб̆ть. Эти 33 шилліона, вошедъ въ оборотъ, потеряли свой кредитъ. Прежнія ассигнащіи ходили не только без'ь лажа, но, чтобъ имгтьь 25 -ти рублевую ассигнацію, платили 26 рублей серебромъ, новыл же ассигнаціи въ началь теряли десять процентовъ; потомъ по времени, и по щърь выпуска из'ъ Банка великаго числа бумажныхъ денегъ, кредитъ онымъ такъ упалъ, что съ 1804 года уже серебренный руббь ходилъ въ 4 рубол.

Съ цругой стороны сказанный заем'ъ принесъ пользу: гупцы употребили оный на заведеніе и перестройку въ городахъ фабрикъ, домов' и каменныхъ лавогъ, отъ чего города улучшились строеніями.

Впосльвдствіи Банвъ сей обращенъ въ осьмильетній, и ревизская душта принималасъ уже в' 150 руббей. Когда учредилось Банковое положеніе на 24 года, то въ Великороссійских'ъ губерніяхъ душа принималась въ 200 р., а въ прочихт въ 150 р.; плата же производилась такъ: по 6 со ста процентовъ и по 2 со ста въ уплату капитала.

Послг̈ нашествія непріятеля дворянство великими пожертвованіями вошло в'ъ неоплатные долги; заложивъ почти всъ свои пм'̆нія, не въ состояніи было уплачивать въ Банкъ положеннаго; пмънія потеряли свою цьнну, и кредитъ упалъ. Для обдегченія въ 1830-мъ году Государь приказалъ уменьшить одинъ пряцентъ, но продолжить вщъ̌сто

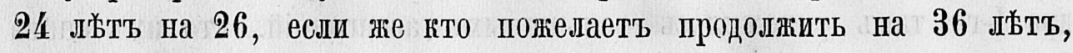
то проценты платитьь по четыре. 
I послаль за отцомъ моимъ, чтобъ онъ туда къ нему пріьхалъ; на другой день, какъ скоро батюшка мой къ нему явился, внязь, полученный уже тогда пукъ ассигнацій показавъ ему, сказалъ: «Видишь, Николай Богдановичъ, у тебя въ губерніи дъзають фальшивыя ассигнаціи, а ты не знаешь? Какъ скоро я проъду Могилевъ, то ту же минуту поручи уголовной палаты предсъ̆дателю Малъеву произвести сльъдствіе, не щадя ни самаго Зорича, ежели будетъ въ подозръніп; я для того не хочу, чтобы ты самъ сльздовалъ, чтобы въ изысканіи вины Зорича и его друзей-плутовъ не былъ употребленъ Энгельгардтъ, мой родственникъ.

Теперь я дъљлаю отступленіе и скажу о жизни Зорича и 0 Шкловъ. Ни одного не было барина въ Россіи, который бы такъ жилъ, какъ Зоричъ. Шкловъ былъ наполненъ живущими людыли всякаго рода, званія и націй; многіе были родственниги и прежніе сослуживцы Зорича, когда онъ служиль майоромъ въ гусарскомъ полку, и жили на его совершенномъ иждивеніи; затъ̌м отставные пштабъ и оберъофицеры, не имъ̌ющіе пріюта, игроги, авантюристы всякаго рода, иностранцы: Французы, Итальянцы, Нъццы, Сербы, Греки, Молдаване, Турки, словомъ, всякій сбродъ и побродяги. Веъхъ онъ ласково принималъ, столь быль для всъхх открытъ; единственно для веселья съъзжалось даже изъ Петербурга, Москвы и разныхъ губерній, лучшее дворянство къ 1 сентября, дню его именинъ, на ярмарки два раза въ годъ, и тогда праздновали недъъли по двъ и болье; въ одинъ разъ было три рода благородныхъ спектаглей, между прочииъ французскія оперы играли княгиня Катерина Александровна Долгорукая ${ }^{\text {30}}$ ), генерал'ь-по-

${ }^{30}$ ) Княгиня Катерина Александровна Долгорукая (ум. 1811 г.) жена извъ̌стнаго князя Юрія Владиміровича (род. 1740, ум. 1830 г.). 0на была дочь фельдмаршала графа Александра Борисовича Бутурлина (род. 1694 г., ум. 1767 г.). M. Л. 
ручица графиня Мелина ${ }^{31}$ ) и прочія соотвътствующія симъ двумъ особамъ дамы и кавалеры; по-русски трагедіи и комедіи-гнязь Прокопій Васильевичъ Мещерскій ${ }^{\text {з2 }}$ ) съ женою и прочіе; балеть танцоваль Д. И. Хорвать сь кадетами и другими, польская труппа была у него собственная. Туть бывали балы, маскарады, карусели, пейерверги; иногда его кадеты дь̆лали военныя эволюціи, предпринимали катанія въ шлюпाгахъ на водъ. Словощъ, не̌ть забавъ, готорыми бы къ себъ хозяинъ не приманиваль гостей, и много отъ него наживались игрою. Хотя его доходы были и велики, но тағоваго рода жизнь ввела его въ неоплатные долги.

Въ числь живущихъ у него быль турецкій князь ИзанъБей, второй сынъ сестры царствовавшаго султана; гогда Зоричъ былъ въ пльнну, онъ съ нимъ былъ знағомъ и пользовался его благодызяніями. Сей князь былъ воспитанъ тайно подъ чужимъ именеиъ, ибо по турецкимъ законамт, сестра султана одного только можеть имъть въ живыхъ сына, а послььдующихъ должна при рожденіи задушать. По материнской природной нъжжности мать сберегла его; когда же начали догадываться, что онъ близгій человъ̌ъ султану, тогда мать его отправила въ чужіе граи, и онъ, бывъ во Франціи, данныя ему деньги всё прожиль, а болъе ему не присылали. Вспомнивъ свое знагомство съ Зоричемъ, пріъхаль въ Шеловъ просить въаимной пюмощи, въ чемъ ену и не было отказано. Онъ былъ прекрасивый и любезный человъ̌ћъ, говориль хорошо по-транцувски и скоро выучился изрядно говорить по-русски; въ посльъдствіи старшій брать его умеръ, и султанъ, узнавъ о неиъ, повволиль ему воз-

i1) Супруга графа Бориса Петровича Мелина, генералъ-поручика (род. 1740, ум. 1793); она была рожденная Грабовская. M. I.

s2) Князь Прокофій Васильевичъ Мещерскій быль при Павлљ I гоФмаршаломъ. $M$. I. 
вратиться въ Константинополь. Многіе Русскіе потошъ его тамъ видызли и сказывали, что данъ ему чинъ подавать султану умываться. If для того сказаль о немъ, чт0 можно ли было подозрьвать кого-либо, съ какимъ намъ̌реніемъ кто тамъ жиль? Тжмъ больье Зановичи могли быть безъ малъйшаго замъзчанія, ибо они пріъхали гакъ путешественники, познакомившись въ Париӝ съ Неранчичемъ ${ }^{33}$ ), роднымъ братомъ Зорича, готораго и ссудили не малымъ числомъ денегъ, пріъхали же имъ̌я паспорты, жили роскошно и вели большую банковую игру.

По слґъдствію открылось, что юаґъ Зоричъ былт много долженъ, то Зановичи хотььли ваплатить за него долги, а Пॉловъ съь принадлежавшимъ имъніемъ взять въ свое управленіе на столью льъть, пока не получать своей суммы съ процентами, Зоричу же давать въ годъ по сту тысячь рублей, по тогдашнему времени большую сумму; для сего просиживали они съ нимъ, запершись, ночи, уговаривая его по сему предмету, и употребленъ въ посредство учитель, бывшій въ корпусь⿻, Салморанъ. Зоричъ говаривалъ, что скоро заплатитъ свои долги и будетъ опять богатъ, что̀ и подало подоврынніе, что онъ участвовалъ въ дъљланіи фальшивыхъ ассигнацій. То же послужило къ таковому невыгодному для него мнёнію, что два гарла мьняли фальшивыя ассигнаціи; это случилось отъ того, что они держали карты, а на большихъ играхъ, особливо когда Зановичи метали банкъ, за карты давали по сту рубоей и болње.

Графы Зановичи родомъ изъ Далмаціи; менышой изъ нихъ

з3) Неранчичъ быль братъ Зорича по своей матери. Фонъ-Визинъ въ письмь своеиъ оть $18 / 29$ сентября 1778 г., писанномъ изъ Ахена къ графу ПІ. Н. Панину, говоритъ о пребываніи его въ Парижь',

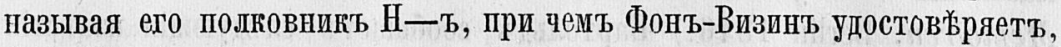
будто бы Даламберъ, Мармонтель и другіе писатели низко льстили невъъжественному Неранчичу, надъъясь получить черезь него подарки отъ Русскаго двора. M. JI. 


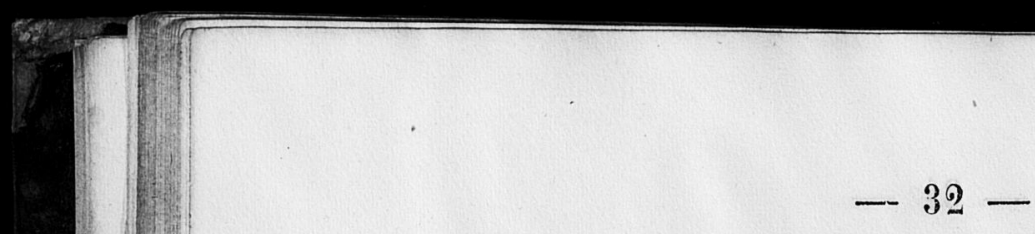

былъ іезуитомъ; по уничтоженіи сего ордена монаховъ, в0звратился къ брату, ґоторый, проживъ имьніе, сталь жить на счетъ ближнихъ разными оборотами. 0ба получили х0ропге воспитаніе, при большомъ умь обогащены были познаніями; во многихъ были государствахъ и вездъ находили простячк0въ, пользовались то игрою, то другими хитрыми выдумками; сказывали даже, что ихъ портреты въ Венеціи были повь̆шены, а они, сдъылавъ какое-то криминальное дъљл0, успґли ускользнуть; тағимъ образомъ встржтились съ Неранчичемъ въ Парижь, кақъ сказано прежде, и видно, что планъ ихъ тогда же иньъљь основаніе.

Когда уговорили Зорича ${ }^{34}$ ) на ихт предложеніе, т0 старшій остался въ Шкловь, а меньшой уб̌халь за границу, подъ видомъ тамъ продать свое имъніе и пріљхать съ деньгами для заплаты долговт Зорпча; но истинный предметь былъ, чтобы тамъ надълать фальшивыхъ ассигнацій и уже пріъхать съ готовыми въ Россію, и для дъъланія оныхъ привезти инструменты. Онъ быль за границею нъ̌сколько мъссщевъ, а по возвращеніи проживаль съ полгода въ

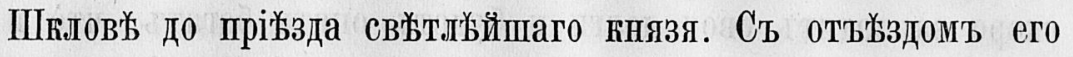
свъттости въ Дубровну, женьшой Зановичъ съ Салмораномъ отправились въ Москву.

Отець мой послалъ одного курьера обогнать его и извъстить главнокомандующаго въ Москвъ, а другаго всль̌дъ дыя надзиранія за Зановичемъ.

s4) Зановичи были в' связяхъ съ знаменитымъ искателемъ приключеній Казановой (род. около 1725 г., ум. 1803 г.), который говорить 0 нихъ въ свопхъ вапискахъ. Трудолюбивый нь̌мецъ Бартольдъ издалъ два тома ровысканій о лицахъ, упоминаемыхъ въ запискахъ Kазановы (Die geschichtlichen Persönlichkeiten in Jacob Casanowa's Memoiren. Berlin 1846.) Бартольдъ сообщаеть сль̌̆дующія извь̌стія o Зановичахъ. Стебанъ и Предиславъ Зановичи были родомъ Далматы; эти пскатели приглюченій начали подвиги свои въ Венещіи, а оттуда отправились путешествовать по Европґ. Стешанъ, посътивши многія 


\section{$-33-$}

Предсъдатель Малљевъ, получивъ наставленія, съ вещскою полиціею и губернскими драгунами, отправился въ ШШюловъ, ночью засталь старшаго графа Зановича въ по-

столицы, вошелъ въ сношенія съ разными знаменитостями и находился между прочимъ въ переписк'ъ съ Вольтеромъ и Даламберомъ.

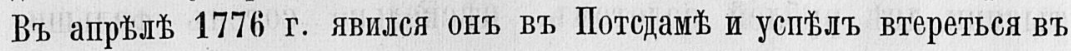
общество принца прусскаго и его супруги. Стефанъ выдавалъ себя за албанскаго господаря, увбрялъ, что у него $\mathbf{3 0 0 , 0 0 0}$ червонцевъ годоваго дохода, и что онъ располагаетъ тридцатитысячнымъ войскомъ. Но вскорь изъ газеть узнали его прежнія нечистыя продъљки, и въ январъ 1778 года его выслали изъ Берлина. 28 января 1778, Фридрихъ II писалъ къ одному ивъ своихъ генераловъ въ Бреславль, чт0 туда прибыль графъ Зановичъ, посъъщавшій разные европейскіе дворы, промышляя обманомъ, а потому его нужно задержать въ Бреславлг, подъ предлогомъ взыскиваемыхъ съ него долговъ. Но

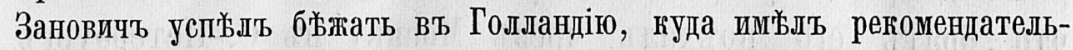
ныя письма оть кавалера Кавалли, венеціянскаго посланника въ Неа-

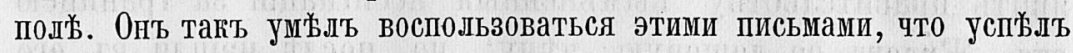
занять у голландскихъ банкировъ 300,000 гульденовъ, которые скоро исчезли. Голландское правительство хотьло взыскать эту сумму съ Кавалли, который отказался платить, говоря, что рекомендательныя письма не суть ғредитивы. Тогда штаты обратились кт венеціянскому правительству за уплатой, но и оно отъ нея откавалось. По әтому случаю дез̆ло чуть не дошло до войны между Голландіего и Венеціей, но императорь Іоситъ II предложилт свое посредство, помирилъ противниковъ, и Голландія отступила отъ своего требованія въ 1779 году. Предиславъ Зановичъ за разныя плутни былъ изгнанъ изъ Флоренціи (Die geschichtl. Persönl. in J. Casan. Memoir. II Band, S. 324-327). Бартольдъ имб̆ль ошибочныя свы̆дьнія 0 дальнъйшей судьбъ Зановичей: онъ говоритъ, что Стефанъ умеръ въ амстердамской долговой тюрьм̌. Записки Л. Н. Энгельгардта открываютъ истину. Въроятно, Стефанъ успьль убъжать въ Парижъ, гдъ нашель своего брата; тамъ повнакомились они съ Неранчиченъ и отправились въ Шкловъ къ Зоричу. М. Л.

Свъдъънія о Зановичахъ, послужившія къ составленію этого прим̌чанія, были доставлены Сергъемъ Александровичемъ Соболевскимъ.

$$
\text { II. II. }
$$


стели, отправиль его за карауломъ въ Могилевъ, прямо въ губернское правленіе; квартиру его окружили карауломъ; также взяты Зоричевы карлы, а съ самого Зорича взята подписка не выъзжать изь дома, пока не сдълаеть отвъта на запросные пункты. На квартиръ Зановича, по осмотръ, ничего долозрительнаго не оказалось; найдено тысячи двь̌ рублей золотомь, ньсколько сотенъ Фальшивыхъ ассигнацій и нъсколько вещей изъ дорогихъ каменьевъ. Камердинеръ его оказался дњвкою, его любовницею, италіянкою, но она ничего не знала, ибо она только ночевала на квартиръ, а в'ь прочее все время была въ дом у Зорича. Князь Изань-Бей быль великій непріятель сихъ побродягь, безпрестанно съ ними ссорился и неоднократно уговаривалъ Зорича, чтобы ихъ прогналъ.

Въ допросъ губернскаго правленія Зановичъ показаль, что брать его поъхаль чрезъ Москву въ С.-Петербургь явить правительству вымънненныя ассигнаціи за границею оть жидовъ за дешевую цьну; но посл官 нашли въ его квартирь подь поломъ всъ инструменты для дъланія ассигнацій, по открытіи чего онъ и отправленъ быль въ С.-Петербургъ; Зорича же совершенно оправилъ въ незнаніи фальшивыхъ ассигнацій.

Меньшой Зановичь схваченъ быль въ Москвъ у самой заставы; найдено сь нищъ слишкомъ 700,000 Фальшивыхъ ассигнацій, все сторублевыхь. Стакнувшись съ братомъ, онъ погазывалъ то же; потомъ, по признаніи ихъ вины, заключены они были въ крьпость Балтійскій портъ. Во время нападенія на оный портъ Шведовъ, въ 1789 году, по малочисленному гарнизону, арестанты были выпущены для защциты онаго; Зановичи оказали особливую ревность и разумными совътами нбъготорыя услуги, за что по освобожденіи порта высланы за границу.

Въ Шкловъ было множество бродягь, такъ что ежели случалась нужда отыскивать какого-нибудь сорванца, то 
государыня приказывала посмотръть, нъть ли его въ Шкловъ, и иногда точно его там'ь находили. Между прочими, во время французской революціи, въ 1792 году, графъ де-Монтегю, бывшій капитанъ корабля во французскомь Флоть королевской службы, подь видомъ эмигранта, императрицею принять быль въ черноморскій флоть; онъ, проъзжая Шкловъ, притворился больнымъ и оставался тамь не малое время. Почтмейстеру казался онъ подоврителеньь, тьиь болье, что не успьљьь туда пріххать, какъ черевь Ригу апресованы были на его имя иностранныя газеты. Одинъ разь почтмейстерь ржшился распечатать и, осматривая съ прилежаніемъ, замьтиль, что на одномъ листьь между строљъ шероховато, а когда поднесь юь огню, оказалось написанное и открылось, что Монтегю быль якобинецъ, и ему было поручено сжечь наш'ь черноморскій Флоть. Сего - Монтегю отправили за карауломъ въ С.-Петербургъ; въ носльдствіи на эшафоть изломали надъ нимъ IIпагу, и сосланъ онъ быль въ Сибирь въ работу.

Вь іюль' 1783 г., мать моя по бользни отправилась въ Нарву (и меня съ собою взнла) пользоваться тамъ оть главнаго доктора г. Сандерса; гдъ пробывт до сентября и не получа облегченія вь своей бользни, отправилась въ С.-Петербургъ. По прибытіи туда, явился я на службу въ Преображенскій полкъ; майоромъ тогда быль генераль-майорь Николай Алексъевичь Татищевъ, пріятель моего отца. 0тыскаль, что я написанъ въ спискь служащихь, и уже

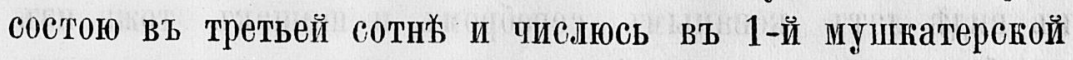
p0T午。

\section{III. Вступленіе мое въ служо̃у до открывшейся турецкой войны вҺ 1788 Году.}

Служба моя въ гвардіи ничтожна и кратковременна; нъкоторое время я быль при роте́ и раза два дежурил'ь, по- 
томъ записанъ быль въ уборные: такъ назывались сержанты, избираемые по высокому росту. Одьты они были въ обыкновенные тогдашніе мундиры; шишаки въ родь римскихь съ богатою серебряною арматурою и панашемъ изъ страусовыхъ перьевъ украшали ихъ головы; сума для патроновъ тожь съ серебряною арматурою. Сіи уборные сержанты стояли по два на часахъ передъ кавалергардскою залой, куда только впускались до капитана; но въ дворянскощь пундирь всякій имљль право туда входить. Я хаживаль, бывъ сержантомъ гвардіи, какъ и прочіе мои товарищи, не въ службъ, въ дворянскомъ мундирь, который во всякомъ чинъ дворянинъ имъљљъ право носить. За сею залою была тронная, у дверей которой стояли по два кавалергарда; не всъ генералъ-поручики и тайные совьтники имьли туда входъ, но ть только, которые имьли на то позволеніе. Кавалергарды были не то, что теперь; пхъ было всего шестьдесять челов'ьљь; выбирались по желанію каждаго, высокаго росту, изъ дворннъ; они всљ считались поручиками въ арміи; капралы были штабъ-офицеры, вахтмейстеръ-полковникъ, порнеть-генераль-майорь, поручикъ былъ свъ̌тльйшій князь Потеукинъ, ротмейстеръсама имшератрица. Должность ихъ была стоять подвое на часа́хъ у тронной, а когда императрица хаживала пњшкомь въ Александро-Невскій монастырь, 30 августа, въ день сего святаго, то они всж ходили по сторонамъ ея ${ }^{\text {s5 }}$ ); мундирь ихъ парадный быль синій бархатный, обложень въ видт лать кованымъ серебромъ и шишакь тожь изь серебра и очень тяжелый.

По пріъздъ свьттльйшаго князя изь Херсонской губерніи, опредъленъ я быль къ нему съ четырьмя другими сержантами на ординарцы; симь заключилась служба моя въ

(3з) Въ послъдній разъ сія процессія была въ 1782 году, а посль того уже она огмьнена. 
гвардіи. 1783 года въ декабръ его свтотлость взялъ меня къ себъ въ адъютанты; онъ тогда еще быль генералъ-аншефомъ и вице-президентомъ военной коллегіи ${ }^{36}$ ); по чину имъљъ одного генералъ-адъютанта преміеръ-майорскаго чина, двухъ Флигель-адъютантовъ капитанскаго чина, да такое же число адъютантовь по званію пефа екатеринославской конницы. Адьютанты его, какъ онъ быљъ вице-президентомь военной коллегіи, имълли право носить всъ армейскіе мундиры, кром' артиллерійскаго, и вообще у всего генералитета адъютанты носили мундиры тьххъ войскъ, какія у нихь были въ конандь; общій знакъ адъютантовъ быль аксельбанть на правомъ плече̌.

Ћнязь жиль во дворц苂; хотя особливый былъ горпусъ, но на аркахъ была сдъљлана галлерея для проходу во дворецъ черезъ церковь, мино самыхт покоевъ императрицы

Лишь только я вступиль въ свое лестное, по тогдашнему времени, званіе, какъ по разнымъ причинамь государыня оказала къ князю немилость, и уже онъ сб́ирался путепествовать въ чужіе краи, и экипажи уже приготовлялись. Князь пересталь ходить къ императриць и не показывался во дворцъ; почему, какъ изъ придворныхъ, такъ и прочихъ знатныхъ людей, никто у него не бывалъ; а сему сльдуя, и цругіе всякаго званія люди его оставили: близь его дома ни одной кареты не бывало; а до того вся Милліонная была заперта экипажами, такъ что трудно было и проьзжать. Княгиня Дашкова, бывшая въ милости и довъренности у императрицы, довела до свьдънія ея, черезъ сына своего, бывшаго при князъ дежур-

(36) Князь Потемкинъ за присоединеніе Крыма въ 1783 году пожалованъ генералъ-фельдмаршаломъ и назначенъ президентомъ военной коллегіи 2 февраля 1784 г. Въ то же вреия назначенъ онъ шефомъ кавалергардовъ и генералъ-губернаторомъ Екатеринославскимъ и Таврическимъ. $\boldsymbol{M}$. $\boldsymbol{J}$. 
нымъ полковникощъ, о разныхъ неустройствахъ въ войскъ: что слабымъ его управленіенъ вкралась чума в'ь Херсонскую губернію, что выписанные имъ Италіянцы и другіе иностранцы, для населенія тамъ пустопорожнихъ земель, за непріуготовленіемь имъ жилиць и всего нужнаго, почти всь померли, что раздача земель была безъ всякаго норядка, и окружающіе его дъљали много злоупотребленій и тому подобное; къ княгинь Дашковой присоединился фаворитъ А. Д. Јанской.

Императрица не совсьум пов'ьрија доносу на свъ̌тльйшаго князя, и черезъ особыхъ в`љрныхъ ей людей тайно узнала, что непріятели ложно обнесли уважаемаго ею свь̆тлййшаго князя, какъ человъка, способствовавшаго къ управленію государствомъ; лишила милости княгиню Даш-

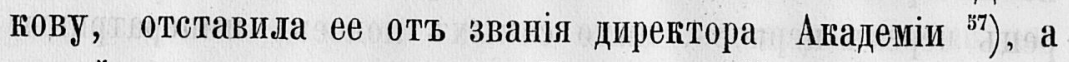

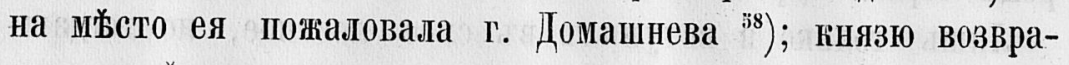
тила довъренность.

Свъьтльйшій князь, въь один'ь день проснувшись, на столь близь кровати видить пакеть, положенный его камердинеромь, изь Грековъ, Захаромь Константиновымь, и который прислань быль оть императрицы, сь тбимы чтобы для сего княвя не будить. Онъ, проснувшись и прочитавь оный, закричал'ь: “Попова!) (такь звали правителя его нанцеляріи). ${ }^{\text {з9}}$ ) $Я$, бывши тогда дежурнымь, повваль его;

57) Туть автор'ь тањже ошибоется: княгиня Екатерина Романовна Дашкова (род. 17 марта 1744, ум. 4 янв. 1810) нь̌сколько разъ подвергалась неудовольствію императрицы, но не въ әто время. Она оставила двор'ь въ 1794 году, сохранив' всъ свои должности, отъ которыхъ отставлена только въ ноябрж 1796 года императоромъ Павломъ I. $\boldsymbol{M}$. $\boldsymbol{I}$.

s8) Сергъй Герасимовичь Домашневъ, камергеръ, ум. 1796 г. Онъ быль директоромъ Академіи наукъ съ 1775 по 1782 годъ, сль̌̆овательно прежде, а не посль княгини Дашковой, ноторая на его мьсто и была назначена. $\boldsymbol{M}$. J.

39) Василій Степановичъ Поповъ роц. 1745 г. Служиль въ Москвъ 
князь подаль ему бумагу и сказаль: “Читай». То быль указъ о пожалованіи князя президентомъ военной коллегіи, то-есть фельдмаршалопъ. Василій Степановичь Поповъ, тогда бывшій подполковникомь, выбъжаль въ комнату передъ спальнею и съ восторгомъ сказаль: «Идите поздравлять князя фельдмаршаломъ). Я на тоть разъ одинъ только и быль; вошел'ь въ спальню, поздравиль его свьтлость. Онъ всталъ съ постели, надъзљ мундирную шинель, повязаль на шею шелковый розовый платокъ и пошелъ къ императриць (такь онъ хаживаль къ ней по утрамъ). Не прошло еще двухъ часовъ, какъ уже всъ комнаты его были наполнены, и Милліонная снова заперлась экипажами; ть самые, которые болье ему оказывали холодности, ть самые болье передъ нимъ пресмыкались; двое, однакожь, во время его невзгодья показали къ нему приверженность, а именно камергеры: Евграфь Александровичь Чертковъ и Александръ Өедоровичъ Талызинъ.

Штатъ по чину его увеличился двумя генеральсъ-адъютантами въ чинь подполковниковъ, и еще двумя Флигельадъютантами въ прежнихь чинахъ. Остался прежній его генеральсь-адьютанть Рибопьерь ${ }^{60}$ ), а другаго взяль меньшаго сына фельдмаршала графа Кирилла Григорьевича Разумовскаго ${ }^{61}$ ), по Екатеринославской конницъ изъ его Флигель-адьютантовъ въ генеральсъ-адъютанты Мамонова ${ }^{62}$ ), который въ посльљдствіи быль Фаворитомъ.

при главнокомандующемъ княз'ь В. М. Долгоруковъ-Крымскомь (17801782), а потомъ перешель къ Потемкину. Умеръ действительнымъ тайнымъ совь̆тником' и членомъ государственнаго совьта въ ноябрь 1822 года. $M$. . I.

6о) Иванъ Александровичь Рибошьер'ь, отецъ обер'ь-камергера графа

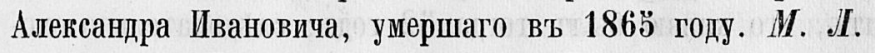

61) Графь Кирилль Григорьевичь Разумовскій, фельдмаршальь, роц. 18 марта 1728 г., ум 9 января 1803 . Сынъ его, 0 которомъ здъсь говорится, назывался графомъ Јьвомъ Кирилловичемъ. $M . d$.

62) Графь Александрь Матвъевичъ Дмитріевъ-Мамоновъ, генераль- 
Теперь почитаю приличнымъ сказать вкратцб 0 происхожденіи и исторіи моего генерала ${ }^{63}$ ), игравшґго роль, какую никто никогда въ Россіи не представляльь и такъ не былъ силенъ.

Родъ свъ̆тльйшаго князя Потемкина был' польскій. Съ завоеваніемъ Смоленска предки его остались въ Россіи; были дворяне, но ни одного не было, который бы занималъ высокія государственныя должности. Петръ Великій употребляљ одного Потемкина для посольства въ Англію ${ }^{64}$ ), но по воввращеніи ничёщъ его не почтилъ. Отецъ внаменитаго сего человъька, огонча службу въ гарнивонь капитаномъ, жилъ въ помьстьъ своемъ, не далеко отъ Смоленска. Князь Григорій Александровичь родился въ 1736 году ${ }^{65}$ ), въ деревнъ Чижевъ,, готорая досталась по праву насльздства оть сестры его, бывшей за Василіемъ

адъютантъ и генералъ-лейтенантъ, родился 19 сентября 1758, ум. 29 сентября 1803. Вліяніе его при цворь началось в'ь 1786 году;

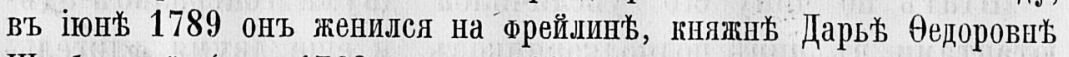
Щербатовой (род. 1762 г. ум. 1801 г.) и удалившись отъ двора, поселился в'ь Москвь̈. М. Л.

63) См. выше, примьч. 4-е.

64) Петръ Ивановичь Потемкинъ, окольничій, быль два раза посыланъ за границу: въ 1667 году въ Испанію и Францію для объявленія Андрусовскаго перемирія Россіи и Польши; въ 1680 году во Францію, Испанію и Англію для объявленія о смерти царя Алексъя Михайловича и постановленія торговаго договора съ Франціей. Онъ умеръ около 1690 года. $M$. I.

$\left.{ }^{65}\right)$ Извъстный знатокт нашей старины II. $\theta$. Карабановъ, бывшій въ родствъ съ Потемкинымъ, нашель, что время его рожденія не 1736 годъ, какъ обыкновенно полагають, а 1739 годъ. Автор'ь предлагаемыхъ Записог' говоря ниже о смерти Потемғина въ 1791 году, также говоритъ, что княвю быль тогда 52 годъ; сльдовательно сходится съ Карабановымъ. Надобно думать, что авторь былъ введент въ заблужденіе, наводя справки по ошибочнымъ указаніямъ. Теперь нельзя сомньваться, что Потемкинъ родился въ 1739 году, именно въ сентябръ мьсяцъ. $M$. $J$. 
Андреевичемъ Энгельгардтомъ, племяннику его Василію Васильевичу Энгельгардту ${ }^{66}$ ); другая сестра его была за Самойловымъ ${ }^{67}$ ), а третія за Высоцкишъ. До двънадцати ль্ьт онъ воспитывался при своихъ родителяхъ. За недостаткомъ учебныхъ заведеній отецъ записаль его въ Смоленскую семинарію, но замьтя въ нешъ пылкой умъ, отправиль въ гимназію Московскаго университета. Въ хараћтеръ Потемкина оказывалось въ то время много странности. “Хочу непремъннно быть архіереемъ или министромъ» часто твердиль онъ своншъ товарищамъ. Поэзія; философія, богословіе и язығи латинскій и греческій были его любимыми предметами; онъ чрезвычайно любиль состязаться, и сіе пристрастіе осталось у него навсегда; во время своей силы онъ держаль у себя ученыхъ раввиновъ, раскольниковъ и всякаго званія ученыхъ людей. Любимое его было упражненіе: гогда всъ разъъзжались, призывать ихъ къ себ̆ъ и стравливать ихъ, такъ сказать, а между тьмм самъ изощрял'ъ себя въ познаніяхъ.

Родители его почи, что военная служба будетъ ему выгоднъе; по ходатайству нъкоторыхъ господъ, записали его въ конную гвардію унтеръ-офицером'ъ и отправили на службу; по дошедшей до него очереди сдъљанъ онъ вахмистромъ. Въ семъ чин'ь быль онъ, когда въ 1762 году произошель перевороть, ръшившій судьбу императора Петpa III-го и вовведшій на престолъ Екатерину II-ю. Образъ его живни доставилъ ему знакомство съ важнъйшими осо-

66) Василій Васильевичъ Энгельгардтъ, любимецъ Потемгина; о нешъ часто будетъ говорено в' әтих' Записках'ь, авторъ которых' быль ему дальнимъ родственникопъ. Сестры В. В. Энгельгардта были: графиня Скавронская и Браницкая, княгиня Голицына, графиня Јитта и г-жа Шепелева. $\boldsymbol{M}$. $\boldsymbol{J}$.

67) Отецъ графа Александра Николаевича Самойлова, бывшаго генераль-прокуророщъ и. умершаго въ 1812 году. $M$. JI. 
бами $\left.{ }^{68}\right)$, участвовавшими въ сей государственной перемъ̌нъ. Во весь день 28 іюня, находился онъ вблизи государыни; былъ въ ея свитъ, когда она поъхала въ ПетергоФ' $\mathbf{b}$.

Екатерина II, вступивъ на престолъ, пожаловала Потемкина офицеромъ гвардіи и потощъ камеръ-юнкеромъ; онъ посланъ былъ въ Стокгольмъ курьеромъ къ находившемуся тамъ россійскому посланнику, графу 0стерману ${ }^{69}$ ) съ извъ̌стіеиъ 0 ея воцареніи.

Возвратившись изъ Швеціи, онъ умॐ้лъ войдти въ тььснъйшую связь съ особами, всегда окружавшими императрицу, и сдъълался болье извъьстнымъ Екатеринъ, принять бывъ въ ея общество, состоявшее ивъ небольшаго числа извъстныхъ людей. Потемкинъ быль прекрасный мущина; имб̆ль привлекательную наружность, пріятную и острую Физіономію, быль пылокъ и в'ъ обществъ любезенъ ${ }^{70}$ ).

Потемкинъ встрьтиль при дворь нъкоторыя непріятности; въ 1769 г. война съ Турціею подала ему случай удалиться на нъсколько времени изъ столицы; пожалованный камергеромъ, отправился онъ въ армію волонтерощъ гдъ участвовал' во многихъ военныхъ дййствіяхъ, въ продолженіи сей войны. Фельдмаршалъ Румянцовъ о славныхъ пойъдахъ послалъ его съ донесеніемъ къ государынъ. Гоеударыня пожаловала его генералъ-поручикомъ и генералъ-

68) Потемкинъ былъ тогда въ близкихъ связяхъ съ 0рловыми. $M$. . I.

${ }^{69)}$ Грабъ Иванъ Андреевичъ Остерманъ, въ посль'цствіи канцлер'ь, сынъ знаменитаго дипломата и любимца Петра I. Онъ род. 1723 г умеръ 18 апрйля 1811 г. $M$. .I.

70) Потемкину нужны были деньги; по преданію ихъ давалъ молодой князь Кантемиръ, владъьлецъ той Черной Грязи (нынъ̆ подмосковнаго Царицына) гдъ, по свидъттельству Записокъ Державина, Екатерина II-я жила съ Потемкинымъ въ уединеніи, льътопъ 1775 года. II. $\boldsymbol{B}$. 
адъютантомъ ${ }^{71}$ ), и онъ снова принятъ быљъ въ число приближенныхъ къ императрицъ. Черезъ ньсколько времени сдълался пасмурнымъ, задумчивымъ, наконецъ оставиль совсъмъ дворь; перегхаль въ монастырь Александра. Невскаго, объявиль, что желаетъ тащъ постричься, отростиль бороду и носиль монашеское платье ${ }^{72}$ ). Великая монархиня, видя въ немт отм'ннное дарованіе государственнаго человька ${ }^{73}$ ), вызвала его изъ сего уединенія, пожаловала генералъ-аншефомъ, подполковникомъ Преображенскаго полка, осыпала всъми щедротами и почестями, а при заключеніи мира съ Турками почтила графскимъ достоинствомъ, какъ непосредственно способствовавшаго своими совъ̌тами. Въ 1776 году римскій императоръ Іосифъ II прислальь ему дипломъ на императорско-княжеское достопнство съ титломъ свътльйшаго; имъљъ всъ россійскіе ордена, громь Св. Георгія (который получилъ посль), ордена всьхъ европейскихъ державъ, кромъ Золотаго Руна, Св. Духа и Подвязки. Въ посльдствіи и въ свое время сказана будеть окончательная его исторія.

Принць це-Линь ${ }^{74}$ ) такь его портретьь изобразиль: «Показывая видь льнивца, трудится безпрестанно; не имь̆-

71) Потемкинъ получиль чинъ генералъ-майора ва взятіе 2 іюля 1769 года укрьпленій подъ Хотинощьь. $\boldsymbol{M}$. $\boldsymbol{J}$.

72 ) Полагають, что люди ему преданные внушили императрицъ, что онъ по любви къ ней возненавидъ̌̈лъ свъьтъ. Самглюбію ея было лестно, и прекрасный, великаго ума человъ̌къ сдълался ея фаворитомъ.

73) Потемкину особенно погровительствовала, при началґ его придворнаго поприща, графиня Прасковья Александровна Брюсъ, сестра фельдмаршала Румянцова, пользовавшаяся неограниченнымъ довњріемъ императрицы. Честолюбіе Потемкина вскоръ получило почти полное удовлетвореніе, но онъ непремьнно хотьль имь̆ть Георгіевскую ленту, которую получиль только за штурмъ 0чакова, 6 декабря 1788 года. M. I.

74) Принцъ де-Линь, Фельцмаршалъ, род. 18 (29) мая 1735 года, ум. 1 декабря 1814 года. Онъ долгое время былъ австрійскимъ по- 
етъ стола, кромъ своихъ кольней; другаго гребня, кромъ своихъ ногтей; всегда лежитъ, но не предается сну ни днеиъ, ни ночью; безпокоится прежде наступленія опасности и веселится, когда она настала; унываетъ въ удовольствіяхъ; несчастенъ отъ того, что счастливъ; нетерпљливо желаетъ и скоро всжумъ наскучиваетъ; философъ глубокомысленный, искусный министръ, тонкій политикъ и вмъсть избалованный девятильстній ребенокъ; любить Бога, боится сатаны, котораго почитаетъ гораздо болье и сильные нежели самого себя; одною рукою крестится, а другою привъ̈тствуетъ тенщинъ; принимаетъ безчисленныя награжденія и тотчасъ ихъ раздаетъ; лучше любитъ давать, чь̆ъ платить долги; чрезвычайно богатъ, но никогда не имъетет денегъ; говоритъ о богословіи съ генералами, а о военныхъ дъълахъ съ архіереями; по очереди имъетъ видъ восточнаго сатрапа или любезнаго придворнаго вйка Лудовика XIV и виъсть погазываетъ изнъъженнаго спбарита. Какая же его магія? Геній, потомъ геній, и еще геній; природный умъ, превосходная память, возвышенность души, коварство безъ злобы, хитрость безъ лукавства, счастливая смъсь причудъ, великая щедрость вь раздаяніи наградъ, чрезвычайная тонкость, даръ угадывать то, чего онъ самъ не знаетъ, и величайшее познаніе людей; это настоящій портретъ Алкивіада.»

По моей молодости и неопытности почти вовсе не дох0дило до моего свъъдънія нитего касательно дворскихъ интригъ, но скажу: какичъ образощъ дворъ по наружности всъмъ былъ извъстенъ. Въ каждое воскресеніе и большой праздникъ быль выходъ ея величества въ придворную цер-

сломъ въ Петербургъ̌ и участвовалъ въ войнй съ Туркамй. Умъ его прославился повсгду, а императрица оказывала ему постоянно знаки уваженія и дружбы. Записки его получили давно общую извъстность. $M$. $\boldsymbol{I}$. 
ковь; всъ, какъ должностные, такъ и праздные, собирались

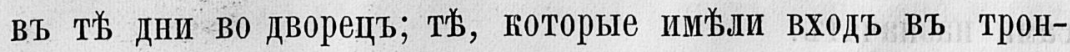
ную залу, ожидали ея величества тамъ; имйющіе входъ въ кавалергардскую залу, въ сей заль-и туть болће всьхъ толпились; а прочіе собирались вь заль, гдъ стояли на часахъ уборные гвардіи сержанты. Военные должны были быть въ мундирахъ и шарфахъ, статскіе во францувскихъ кафтанахъ или губернскихъ мундирахъ и башмакахъ; всь должны были быть причесаны съ буклями и съ пудрою; оберъгофмаршаль и гофмаршалы, заранъе до выхода императрицы, ходили по кавалергардской зальь и, ежели усматривали ґого неприлично одъ̌тымъ, то просили таковаго въъливо выйдти. За нб̌сколько времени насльљдикъ великій князь съ великою княгинею, изъ своей половины, проходили во внутреннія комнаты государыни, которая въ половинь্ одиннадцатаго часа выходила въ тронную, гдъ чужестранные министры, знатные чиновники и придворные ея ожидали. Тамъ представлялись пріжзжіе, или по инымъ какимъ причинамъ имьющіе входъ за кавалергардовъ; тамъ она удостоивала со многими разговаривать. Въ одиннадщать часовъ отворялись двери; первый выходиль оберъ-гофмаршаль съ жезломъ, за нимь пажи, камеръ-пажи, камерь-юнкеры, камергеры и кавалеры, по два въ рядъ; предъ самою императрицею св'ътльйшій князь. Государыня всегда имхула милый, привлекательный и веселый, небесный взглядъ. Ежели были пріьзжіе или отьъзжающіе, или благодарить за какую милость, но не имьющіе входа въ тронную, то представляемы были туть оберъ-камергеромъ, и государыня жаловала цьљловать имь ручку. За императрицею шель великій князь, рядомь съ великою княгинею; за ними статсь-дамы, гамерђ-Фрейлины и фрейлины, по дв въ рядъ. Тжнгъ же порядкомь государыня возвращалась во внутреннія комнаты. Императрица кушала въ чась. Ежели кто хотьль быть представленъ великому князю и великой княгине, то пред- 
ставлялся на ихъ половинъ̌ въ день, когда ихъ высочества сами назначать.

Каждое воскресенье быль при дворь баль или куртагъ. На баль императрица выходила въ такомъ же порядкъ; какъ и въ церковь; передъ залою представлялись дамы и цъылвали ея ручку. Баль всегда открывалъ великій князь съ великою княгинею иинуэтомъ; посль ихъ танцовали придворные и гвардіи офицеры; изъ армейскихт ниже полюовниковъ не имтли позволенія; танцы продолжались: минуэты, польскіе и контрдансы. Дамы долюны были быть въ русскихъ платьяхь, то-есть особливаго покроя парадныхъ платьяхъ, а для уменьшенія роскоши быль родъ женскихъ мундировъ по цвььтамъ, назначеннымъ для губерній. Кавалеры всъ должны быть въ башмакахъ. Все дворянство имъло право быть на оныхъ балахъ, не исключая унтеръофицеров'ь гвардіи,-только въ дворянскихъ мундирахъ.

Императрица игрывала въ ғарты съ чужестранными министрами или кому прикажеть, пля чего карты подавали ть̆ъ по назначенію камеръ-пажи; великій князь тоже играль за особливымь столикомь. Часа черезь два музыка переставала играть; государыня откланивалась и тььыъ же порядкомъ отходила во внутреннія ғомнаты. Посль' нея спьІІили всъ разъъзжаться.

Въ новый годъ и еще до великаго поста бывало нысколько придворныхъ маскарадовъ. Всякій имъль право получить билетъ для входа въ придворной конторъ. Купечество имьло свою залу, но объ валы имъли между собою сообщеніе, и не запрещалось переходить изъ одной въ другую. По желанію уогли быть въ маскахь, но всъ должны были быть въ маскарацныхъ платьяхъ: доминахъ, венеціянахъ, капуцинахъ и проч. Императрица сама выходила маскированная, одна, безъ свиты. Въ буфетахъ было всянаго рода прохладительное питье и чай; ужинь быль только по приглашенію оберь-гофмаршала, человъьь на сорокъ въ кавалерской 
залъ. Гвардіи оФицеръ наряжался для принятія билетовъ; ежели пт0 пріъзжаль въ маскъ, долженъ былъ предъ оФицеромъ маску снимать. Ћто первый пріъзжал'ь и кто посльъднй у'ззаль, подавали государынъ записку: она была любопытна знать весельчаковъ. Какъ балы, такъ и маскарады начинались въ шесть часовъ, а маскарадъ оканчивался за полночь.

Одинъ разъ въ недъъљю было собраніе въ эрмитажъ, гдъ иногда бываль и спектакль; туда приглашаемы были люди только извъстные; всякая церемонія была изгнана; императрица, забывъ, такъ сказать, свое величество, обходилась со всъми просто. Были сдъыланы правила противъ этикета; кто забываль ихъ, то долженъ былъ въ наказаніе прочесть нъ̆сколько стиховъ из'ь Телемахиды, поэмы стариннаго сочиненія Тредьяковскаго.

у великаго князя по понедъљльникамъ были балы, а по субботамъ на Каменномъ островъ, по особому его приглашенію, лично каждаго, чрезъ придворнаго его половины лакея; а сверхъ того наряжались по два гвардіи офицера отъ каждаго полка.

Въ Европь⿱⺊口 славилась тогда пъвица г-жа Тоди ${ }^{75}$ ) и пьъвецъ Маргези ${ }^{76}$ ); никогда они вмъстъ не съъзжались, но императрица убъдила ихъ обоихъ прибыть въ Петербургъ. Г. Сарти ${ }^{77}$ ), извъьстный сочинитель музыки, сочиниль оперу: Арлида и Рено; всъ аріи согласовались съ желаніемъ сихъ двухъ именитыхъ артистовъ. Во время представленія, один'ь надъ другимъ стараясь одержать поверхность, пҺніещъ своимъ они удивляли и восхищали знатоковъ и любителей музыки.

75) Пъвица Тоди ненавидъљла знаменитаго Сарти и успъла поврецить ему на ньъкоторое время при дворъ. $\boldsymbol{M}$. Л.

${ }^{76}$ ) Јуиджи Маркези, одинъ изъ славнъйшишхъ пҺвцовъ-кастратовъ, родощъ миланецъ, род. 1755 г., ум. 3 (15) декабря 1829 г. М. Л.

${ }^{77}$ ) Іосифъ Сарти, рощ. 1730, ум. 1802. Онъ пріъхаль въ Петербургъ въ 1785 г. Лучшею его оперой считается Армида. M. II. 
Образъ жизни вельможъ быль гостепріимный, ло мъръ богатства и званія занимаемаго; почти у всъхь были объденные столы для ихъ знакомыхъ и подчиненныхъ; люди праздные, ведущіе холостую жизнь, затруднялись только избраніемъ, у кого объдать или проводить съ пріятностію вечеръ. Въ семъ случаъ фельдмаршаль, графь Кирилла Григорьевичь Разумовскій ${ }^{78}$ ), отличался отъ прочихъ. У него ежедневно быль открытый столь для пятидесяти человъкь; много бывало у него за столомт такихт гостей, которыхъ онъ никогда не знавалъ. Разсказывали, что графъ любиль играть посль⿱ обьда въ шашки, безь денегь, а какъ оная игра мало приносила удовольствія, т0 мало было и охотниковъ. Случилось, чт0 какой-т0 штабъ-оФицеръ въ одинь день у него объдаль; по предложенію, кому угодно играть въ шашки съ его сіятельствомъ, сей штабъ-0Фищеръ радъ быль таковой чести, и уже всякій день, недъљль съ шесть, продолжаль сію игру. Вдругь сего майора не стало; по привычкъ графъ его спрапивалъ, но никто в'ь домь не зналъ, кто этоть быль господинъ майоръ, откуда онъ пріьхаль и гуда дьвался.

По воскресеніямъ у вище-канщлера графа Остермана ${ }^{79}$ ) бывали балы. Вообще много было открытыхъ домовъ, гдъ весело провожали время, а особливо у оберъ-гофъ-шталмейстера јьва Александровича Нарышкина ${ }^{80}$ ).

Публичныя увсселенія были: два театра, на которыхъ играли русскіё актеры трагедіи, комедіи и оперы; въ трагедіи отличался своимь неподражаемымъ талантомь $\mathbf{r}$ Дмитревскій ${ }^{81}$ ). Франщузская была прекрасная трупша для

$\left.{ }^{78}\right)$ Который никогда и ротой не командовалъ.

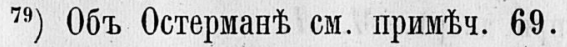

80) Левъ Александровичь Нарышкинъ, оберъ-шталмейстеръ, род. 23 февраля 1733 г., ум. 9 ноября 1799 г. 0нъ былъ извъстен'ь роскошною жизнію, остротой ума и неистощимою веселостію. $\boldsymbol{M}$. $\boldsymbol{I}$.

81) Иванъ Аөанасьевичъ Дмитревскій (Нарыковъ), род. 23 февраля 1736 , ум. 27 октября 1821 г. $M$. $\mathscr{I}$. 
трагедіи и комедіи, италіянская опера-буфа, которую императрица $\left.{ }^{82}\right)$ ивъ всъхъ театральныхъ позорищъ болье всего жалөвала. Въ балеть тогда отличался Роветти, какъ прыгунъ, а Пикъ для характеристическихъ танцевъ. Въ большомь каменномъ театрь каждый четвергь г. Морсаньи даваль маскарады; платили за входъ по одному рублю и посьщали оные какъ всъ знатные обоего пола, такъ и вся публика, маскированные и безъ масоюъ. Императрица не однократно инкогнито бывала замаскировавшиись съ фаворитомъ своимъ Јанскимъ, въ сопровожденіи статсь-дамы трафини Браницкой ${ }^{83}$ ) и камерь-фрейлины Протасовой ${ }^{84}$ ).

Былъ музыкальный клубъъ, гдъ̌ каждую недъљљю по понедъъльникамъ были концерты и многія другія вольныя для увеселенія заведенія. Игры азартныя хотя закономъ были запрещены, но правительство на то смотрьљло сквозь пальцы. Словомь, всъ, жившіе въ Петербургь, жили вольно и пріятно, безъ всякаго принужденія; однакожь благопристойность строго соблюдалась, ибо старались быть принятыми въ хорошемь обществъ, а для того надобно было имьтьь репутапію безъ мальй̆пгаго пятна и тонъ хоропаго воспитанія.

82) Увъ̆домилась она, что графъ Безбородко далъ 40,000 актрисъ Давіи, и какъ сіе знала вся публика, что государственный тоть человъь'ъ употребшль таковую знатную сумму, повельла актрису Давію выслать в'ь 24 часа за границу, а потощь и всю оную труппу выслать.

${ }^{83}$ ) Графиня Александра Васильевна Браницкая, урожденная Энгельгардтъ, роп. 1754 , ум. 1 ав авуста 1838 г. Она была за мужемъ за короннымъ великимъ гетманом' польскимъ, графомъ ћсаверіемъ Петровичемъ, бывшимъ потомь русскимъ генераломъ. Князь Потемкинъ любилъ ее, болье всъ̌хъ свопхъ племянницъ. $\boldsymbol{M}$. $\boldsymbol{I}$.

84) Анна Степановна Протасова, родственница 0рловыхъ, камеръфрейлина, получила графское достоинство въ 1801 году сентября 17, ум. 12 апръля 1826. Өна пользовалась особеннымь благоволеніемъ Екатерины II. $M$. $\boldsymbol{J}$. 
Образъ жизнй моего генерала быль елинообразенъ; всягое утро домь его наполнлея вешьмонам, особливо военными, но его ры́двіе кто видали. Онъ- веелда быль въ своей спальнь И вь шлафоркб; промь самовнатныхъ людей и короткихь его внағомыхь никто не входныт туда безъ доклада. Въ часъ онъ объдаль; его сөбственный столь быль на осьмнадцать приборовъ, да дын літата его, въ другой заль, на двадцать четыре прибора. Кағь столь, такъ и все прочее было на бчеть двора, равно и услуга. Јюбиль играть въ воирерческія игры, а иногда и въ бангъ. Любиль лағомиться самыми грубыми вещами, для чего старались ему доставлять по его вкусу, не только изъ Петербурга какт-то: хорошіе соленые огурцы, капусту и тому подобное, но пзь туберній; съ нарочныии курьерами доставляли: изъ Урала икру, изъ Астрахани рыбу, изъ Нижняг0-Новгорода нодновскіе огурцы, изъ Калуги-калужское тъьсто. Иногда князь выъзжаль на вечера и балы, а особливо ко Јьву Александровичу Нарышкину; об̆ъдать иногда ъзжаль къ Матвею Өедоровичу Башталинскому ${ }^{83}$ ), у котораго почитался самый лакомый столь, и собирались знатныйшіе гарточные игроки. На балы великаго князя и на Каменный Островъ ни одного раза не миновал'ъ. Јюбил'ь смотрьть на искусных й игроковъ въ билліярдъ, почему всъхъ лучшихь искусниковь отыскивали и къ нему привозили; тоже любиль смотрбть игру шахматъ, для чего изь Тулы выписали одного пупца, и онъ возиль его съ собою даже и въ армію. Многіе, чтобы быть извъстными его свътлости, старались имйть кь нему входь и его забавлять.

85) Матвей Өедоровичъ Кашталинскій былъ долгое время оберъцеремоніймейстером' при Екатеринъ̌ II. По свицьтельству С. Н. Глинки, Кашталинскій быль милостивщемъ всъхъ пріхзжавшихъ въ Петербургъ Смольянъ; можетьь быть, он'ь нъ̌когда покровительствоваль и Потещгину. II. $Б$. 


\section{$-51-$}

1784. Въ началь 1784 года свътльйшій князь преобразиль армію въ новую өлежду. Передъ симь гренадеры имъли стариныя тренӑдерскія шапк; мушкатеры, кавалерія и артиллерія носили шляшы; вся арпія причесана была сз оуклямй, длинными косами и пудрою, что́ особливо было тягостно для нињших чиновъ; зимою одъты были въ длиные пундиры; а льотомь въ красные камзоль сь ругавами. По введенной же свътітйшимь князеиъ рефоржъау всей арміи волосы были обетрижены в'ь кружоЋъ, как можно ниже; виъсто шлянь и гренадерскихъ шапогь даны легкія каски съ плюмажемь изъ шерсти; у гренадеровь и ћирасирт плюмажи бълые, спереди латуны съ вензеловымъ именемъ императрицы; у прочихъ войскъ плюмажи желтые съ простою полосою латуни. Вмб̌сто долгополыхь мундировъ сдъљаны были куртки; вмъсто короткихъ штановъ чикчиры сверхъ сапогь, внизу обшитые черною кожею и застегивавшіеся шестью мъ̌дными пуговицами; на льтто всљ нижніе чины имъли юителй изт Фламскаго полотна съ широкими шароварами. Слободскіе гусарскіе полки уничтожены, а вмъсто оныхъ сформировано десять легк0-гонныхъ польовъ, по шести эскадроновъ каждый. Гвардія сохранила прежніе свои мундиры И прическу. Генералитетъ, штабъ и оберъ-офицеры остались также въ прежнеиъ видъ. Когда его свътлость представиль на утвержденіе императрицъ дољладъ, то надписаль: “Солдатскій нарядъ долженъ быть таковъ: тто всталъ, т0 готовт).

Въ исходъ̌ зимы князь отправился въ свои туберніи, гакъ для осмотра оныхъ, такъ и для того, чтобъ увидъ̌ть преобразованіе арміи въ новой одеждъ̌ . Еще болъе ему нужно было быть тамъ, чтобы выманить хана Шагинъ-Гирея ${ }^{86}$ )

86) ШІагинъ-Гирей, ханъ грымскій, быщъ покорнымъ орудіемъ Русской политики въ Крыму, гдъ Россія подцерживала его права съ 1775 
изъ горъ, гдъ онъ съ приверженными себъ Крымскими Татарами укрывался, увидя, что быль обманутъ обыщаніями, данными ему за добровольное его подчиненіе Россійской державъ, не исполненными въ посльздствіи. Безъ того спогойствіе въ Крыму было непрочно. Но князь не хоть⿻ыљ прибъгнуть къ силъ. Внезапная смерть фаворита А. Д. Јанскаго, коего государыня жаловала болье прочихъ, заставила его безъ медленія отправиться въ Петербургъ. Начальство надъ войсками поручилъ онъ генералъ - поручику Игельстрому ${ }^{87}$ ), равно поручилъ ему и уговорить хана, а потомъ отправить его въ Воронежъ. Игельстромъ, въ отсутствіе князя, приступилъ къ исполненію сего такимъ образомъ.

До его командованія войска очень дурно обходились съ Крымцами, и несмотря на ихъ жалобы, никогда не давали имъ должнаго удовлетворенія; тожь неодногратно и просьбы хана, въ заступленіи обидъ и притъсненій его бывшихъ подданныхъ, оставались безъ вниманія. Игельстромъ сталт строго наказывать по просьбамъ Татаръ, праваго и неправаго; сталь имъ всячески поблажать. Ханъ вошель съ нимъ въ переписку, благодаря, что онъ его бывшихъ подданныхъ покровительствуетъ и защищаеть оть страшныхъ угнетеній. Наконецъ они сдъзлались по письмамъ друзьями, и ханъ такъ расположенъ былъ къ нему, что просиль его къ себъ пріћхать въ горы. Черезъ нъсколько времени Игельстромъ получиль курьера съ маловначущими бумагами. 0нъ сдъ̌лался задумчивъ, паспуренъ; запершись

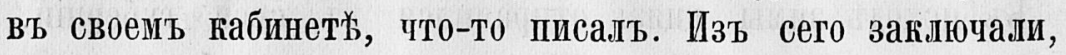

гөда, когда правившій тамъ братъ его Сагиб'ь-Гирей, покровительствуемый Турціей, былъ вынужденъ бћ̆жать ивъ Крыма въ Константинополь, и сильная партія избрала въ ханы Девлетъ-Гирея. $\boldsymbol{M}$. $\boldsymbol{J}$.

87) Графъ 0сипъ Андреевичъ Игельстромъ, генералъ отъ инфантеріи, умерь въ 1817 году; нравъ Игельстрома изображенъ въ Запискахъ \#. Б. Мертваго. ПI. Б. 
что върно получиль онъ какую-либо непріятность, и не приказано ли уже ему сдать войска старшему по себґ, а

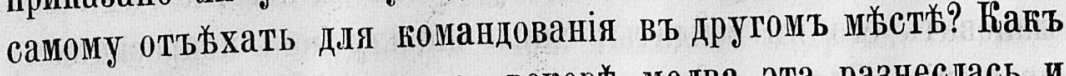
онъ былъ ненавидимъ, то вскорь молва эта разнеслась и дошла до хана.

Ханъ кан'ь скоро то услышалъ, то съ большимъ собользнованіешъ спрашиваль его письмомъ: справедлива ли эта молва? Игельстромъ отв Һчалъ, что ему вельно ьхать помандовать Ћавказскимъ корпусомъ, и онъ болье всего сожальетъ, что отъъзжаеть, съ нимъ не видавшись. Ханъ пишеть, что онъ въ отчаяніи, видя Крымщевъ своихъ лишенныхъ таковаго покровителя, и предлагаеть ему, что объъздъ на Кавказь очень далекъ, а ежели онъ поъдетъ чрезъ его станъ, въ горахъ находящійся, то ему несравненно будеть ближе и покойнье; что это есть средство лично запечатльть его сь нимъ цружбб. То было только и нужно Игельстрому. Онъ отвъчаль хану, что очень благодаренъ за таковое его приглашеніе, и что какъ скоро онъ сдасть команду, то, извъстя его заранье, воспользуется симъ случаещъ имьть давно-желанное съ нимъ свиданіе.

Игельстромъ нарядиль одинъ батальонъ съ четырыми пушками, выбраль къ тому способнаго штабъ-офицера, далъ ему маршруть какъ бы для безопаснаго его проьзда и особливое наставленіе, чтоб'ь онъ, показывая, будто сбился сь дороги, въ назначенное (до прівзда Игельстрома) число, очутился близь ханскаго стана и бросился бы къ хану просить его защиты въ ошибнь, имъ сдъљанной (ибо-де Игельстромъ безъ того сдълаеть его несчастнымъ); а потомъ выпросиль бы позволеніе для чести поставить въ карауль роту близь ханской ставкп: инако-де Игельстромь его не простить.

Игельстромъ, учредивъ сіе, съ большичъ конвоемъ кавалеріи, подь видомь провода, съ нькоторыми генералами и множествомъ штабъ и обееръ-офицеровъ, отправился въ 
станъ хана. По прибытіи же туда, какъ скоро увидъљљь того штабъ-офицера, то и напустился на него, хотьль разжаловать его въ солдаты; ханъ насилу могь испросить ему прощеніе. Посль̌ сей комедіи вошли они къ хану въ палатку. Туть Игельстромъ соросиль сь сео̆я личину, сталь уговаривать хана отдатьсл и предать себя справедливой монаршей милости. Хотя тогда ханъ и увидъљл себя обманутымъ, но уже нечего было дълать; окруженъ будучи батальономь съ пушками и больве нежели тысячью человёкъ россійской конницы, онъ долженъ былъ согласиться. Въ тоть же день хана вывевли, и вскоръ былт онъ отправленъ на житье въ Воронеж'ь.

1785. Императрица очень оорадована была пріґздомь князя; потерею любимца своего она огорчалась: на нйкоторое время при дворь остановлены были всъ увеселенія. Въ придворной церкви у об̆̌дни, сколько молодыхъ людей вытягивались, кто сколько нибудь собою быль недуренъ, помышляя сдъылать такъ шегко свою фортуну. Частая перемьна фаворитовь каждаго шьстила, видя, что не всь они были геніп, почти всъ изь мелкаго дворянства и неполучившіе тщательнаго воспитанія. Нанонецъ выборъ паль на гвардіи офицера Александра Петровича Ермолова $\left.{ }^{88}\right)$. Касательно его наружности, онъ не быль отлично хорошъ, особливо въ сравненіи съ прежними фаворитами, а еще болье съ посль'ынимъ Ланскимъ; тоть быль большаго роста, стань имьљљ прекрасный, мужественный, черты лица правильныя, цвътт лица погазываль здороваго и крьпкаго сложенія человъька, а Ермоловъ быль женоподобенъ, умомъ же не превосходиль посльдняго, котораго считали не слишкомъ дальновиднымъ.

88) Александръ Петровичь Ермоловъ, генералъ-поручикъ, род. $1754 \mathrm{r}$, ум. 1836 г. Вліяніе его при дворь начинаеть быть замьтено съ начала 1785 года. Въ іюнъъ 1786 года онъ удалился оть двора и долго путешествоваль по Европґ. $\boldsymbol{M}$. $\boldsymbol{J}$. 
Я недъ̌ли двъ̌ быль нездоровъ и не выъзжжаль изъ дому; получивши облегченіе, пріъхалъ къ князю и увъ̌домиля, что Мамоновъ пожалөванъ былъ капитанъ-поручикомъ гвардіи, а на иъсто его взять въ адъютанты Ермоловъ и живетъ во дворць, въ отдъзеніи его свъ̌тлости. Я тотчаст пошель къ нему знакомиться. У комнаты его стонль придворный камеръ-лакей; я хотй.тъ войдти прямо къ Ермолову, но камеръ-лакей остановиль меня и спросиль: «Какъ прикажете 0 сеоъ доложить?) Я быль столько простъ, тто не догадался, къ чему готовится мой товарицъ и сказалъ: “Что это за странность, что безъ доклада войдти не можно?» Однакожь даль время о себж доложить. Ермоловъ принял'ь меня очень вйтливо, но свысока; я простодушно рекомендовалт себя въ его знакомство. Онъ былъ знакомъ съ моею матерью въ Москвъь и считаль за милость, что она его хорошо принимала, почему обошелся со мною ласково и объщщаль при случаъ оказывать мнъ̆ свои услуги.

Свъัтутйшій князь приготовиль большой праздникъ въ Аничковскомъ своемъ домь или, лучше сказать, павильйонь. Въ день сего великоль̆наго маскарада, приказано было всему его свћтлости штату быть въ мундирахъ легкой конницы и въ шарфахъ. Собравшись еще до пріжзда князя, увидъ̌лъ я Ермолова въ драгунскомъ мундиръ и въ башмакахъ; по добродушію своему, подошедъ къ нему, сказал'ъ: «Александрь Петровичъ, развъ вы не знаете, что вельно всъиъ намъ быть въ мундирахъ легкой конницы, въ сапогахъ и въ шарфахъ?)—(Я знаю, отвъччалъ онъ мнъ̆, но думаю, что его свътлость на мнб̆ не взыщетъ.»- “Остерегитесь, лучше поьзтайте домой и переодъньтесь.»- “Не безпокойтесь, сказаль онъ, однакожь не менъе я вамъ благодаренъ за ваше ко мнъь доброе расположеніе.» Вскоръ его свььтлость пріжхаль, и представьте себъ мое удивленіе, когда онъ взялъ Ермолова подъ руку и сталь ходить съ нимъ по заль, чего онъъ и самыхъ знатныхъ бояръ не удостоивалъ. 
Когда всъ съъхались, прибыла императрица съ великими княвьями, и съла играть въ карты, а Ермолова поставили отъ нея шагахъ въ четырехъ впереди всъхъ вельможъ, стоявшихъ вокругъ государыни. Тогда только я догадался, къ чему сего адъютанта готовили.

Маскарадь былъ чрезвычайно великоль̆шен'ь; болье двухъ тысячъ человъьъъ было въ богатыхъ юостюмахъ и доминахъ. Болышая длинная овальная галлерея къ одной сторонъ огорожена была занавъ̌сомъ, а въ другомъ концъ сдъљанъ былъ оркестрь пирамидою, убранный съ великимъ вкусомъ; боль̌е было ста музыкантов'ь съ инструментальною, духовою, роговою и вокальною музыкою, управляемою майоромъ Росетти, всегда находившимся при князъ; на самомъ верху пирамиды былъ поставленъ въ богатой одеждъ литаврщикъ Арапъ. Вся галлерея освъ̌щена была висящими гирляндами вдоль и поперегь, на готорыхь поставлены были свъчи.

Двъ пары танцовали кадриль: князь Дашков'ь ${ }^{89}$ ) съ княжною Барятинскою, въ первый разъ показавшеюся въ публикь и Удивившею всъхъ своею красотою, а особливо ловкостью и гибкостью своего стана (которая посль была замужемъ за князем' В. В. Долгоруковым') ${ }^{90}$ ). Она оджта была просто в'ь бжломь платьљ, а кавалеръ ея сверхъ мундира вть бъбломь домино. Вторая пара была графиня Матюшкина (которая посль' была замужемь за графомъ Віельгорскимъ) ${ }^{91}$ ), кавалеръ ея быль граф'ь Г. И. Черны-

89) Князь Павелъ Михайловичъ Дашковъ - сынъ знаменитой Екатерины Романовны Дашковой, рожденной Воронцовой. Онъ род. 1761
года, умерь 1807
г. $M$. .

90) Кінягиня Екатерина Өедоровна Долгоругова, статс'ь-дама, супруга князя Василія Васильевича (сына Долгоругова Крымскаго) Она родилась 29 октября 1769 г., умерла 30 октября 1849 r. M. d.

91) Графиня Софья Дмитріевна Віельгорская, ум. 1796 г. Она была мать изв'ьстнаго композитора графа Михаила Юрьевича, недавно умершаго оберъ-шенком'ь высочайшаго двора. $\boldsymbol{N}$. $\boldsymbol{d}$. 
шевъ ${ }^{92}$ ), 0бъ пары танцовали такъ, что я въ жизни моей лучшихъ танцовщиковъ не видалъ.

Ћогда настало время ужина, хозяинъ доложиль 0 томъ императриць; лишь только она подошла къ занавъсь, какь она была поднята, и явился столь богато-убранный, каюъ бы нъкоторымъ волшебствомъ. Императрица кушала за особымъ круглымъ столомъ съ великими князьями, статсъ-дамами, камеръ-фрейлинами, чужестранными министрами и нъ̌которыми самыхъ первыхъ степеней кавалерами; вокругъ сего былъ поставленъ в'ъ полцркуля другой болышой столъ, такъ что сидящіе за онымъ обращены были къ ней лицомъ; въ то же время, въ одно мгновеніе, внесено было до сорока малыхъ столовъ, каждый о двъннадцати кувертахъ, убранныхъ и освещщенныхъ. Передъ тьмъ, какъ императрицъ встать изъ-за стола, всъ они были вынесены и въ одинъ мигъ исчезли, равно и завъса опустилась. По нъкоторомъ времени, императрица съ великими князьями изволила отбыть. Маскарадъ продолжался до трех'ь часовъ.

На другой день новый фаворить заняль во дворцжо обыкновенныя комнаты, гдъ они пребывали; пожалованъ быль Флигель-адъютантомъ ея величества ${ }^{93}$ ) п станиславскимъ

92) Из'ь вс'ъхъ четырехъ графов'ь Чернышевыхъ, Петра, Григорія, Захара и Ивана Григорьевичей, только у посль̆дняго былъ одинъ сынъ, графъ Григорій Ивановичъ, о которомъ здъ̌сь говорится. Онъ умеръ въ 1830 году в'ъ званіи оберъ-шенка; фамилія и титулъ его были переданы мужу его дочери, Ивану Гавриловичу Кругликову, виъ̌с⿰氵 съ извъ̌стнымъ Чернышевскимъ майоратомъ, учрежденнымъ въ 1774 году графомъ Захаромъ Григорьевичемъ Черныпевымъ. $\boldsymbol{M}$. $\boldsymbol{I}$.

93) Флитель-адъютанты ея величества были полковники, но они сохраняли свое званіе, даже быв'ь въ генералъ-майорскомъ чинъ. У нихъ былъ особливый мундиръ съ шитьемъ и аксельбантомъ, съ вензеловымъ именемъ императрицы; впрочемъ они могли носить мундиры всей арміи. Чтобы быть Флигель-адъютантомъ, надобно было имьть великій фаверъ; право ихъ было по желанію оставлять свои полки 
кавалеромъ, чрезъ нъ̌сколько дней генераль-майоромь и кавалеромъ Бълаго Орла. Таковъ быль ходъ всъхъ фаворитовъ.

Въ исходь́ сего года мать моя скончалась, а сестра моя Александра Николаевна выпущена была изъ Смольнаго монастыря; мн поручено было ее принять и привезть къ отцу моему въ Могилевъ, для чего князь отпустилъ меня безсрочно въ отпускъ, Посль уже я по должности въ Петербургъ̌ не бывалъ; ибо въ 1785 году пожалованъ я быль секундъ-майоромъ къ иррегулярнымъ войскамъ ${ }^{94}$ ).

или бригады, во всякое время, даже и въ военное, объявя только начальнику, командующему тою частію войскъ, въ которой состоятъ подъ командою, чтоо б̆дутъ къ своей должности ко двору. По службъ это было большое злоупотребленіе: при мальйшемъ неудовольствіи всегда сіи флигель-адъютанты пользовались сего несправедливою привилегіею.

94) Въ теченіи сего времени случилось сльљующее происшествіе: фрейлина Эльмтъ, г-жа Дивова, братъ ея, флигель-адъютантъ ннязя Потемкина, графъ Бутурлинъ и нь̌оторые другіе сдъ̆лали на многихъ знатныхъ людей сатиру въ рисункахъ, съ острыми язвительными и оскорбительными надписями для многихъ лищъ, въ которой не пощажена и сама императрица. Долго не находили сочинителей сего пасквиля, а въ удовлетвореніе болье потерпьвшихъ безславія оный сожженъ былъ на әпафоть্ палачомъ. Но по ны̆которомъ времени паригмахерт, убирая фрейлину Эльмть и имя надобность въ бумагахъ на папильйоты, взглянуль въ уголь и видя разорванные лоскутки бумаги, хоть্лъ оные употребить, но взявши ихъ увидйль рисунки лицъ, подобралъ всъ и представиль обер'ь-гофмаршалу, который узналь ту сатиру, надписаннуг рукою фрейлины Эльмть, донесъ императриць, почему и открылись всъ авторы. Фрейлину Эльмть, какь говорили, оберъ-гофмейстерина высъьла розгами, и отправлена она была къ ея отпу въ Лифляндію. Дивова съ мужем'ь удалена изъ столицы; графъ Бутурлинъ отставленъ съ запрещеніемъ въъзжать въ мьстопребываніе государыни. Всъхь остръе изображенъ быль Безбородко, недавно пожалованный графощъ: онъ держаль книгу съ надписью: Le comte nouveau relié en vean. Еслибы подобныя сему были всъ насмьшки и не гасались обруганныхъ въ нравственности лицъ, то конечно поступлено бы было болье нежели снисходительно. 
1786. Въ іюнъ 1786 года Ермоловъ вышелъ изъ фавёра; дано ему было въ Могилевской губерніи шесть тысячъ душъ. А на мъсто его поступиль Александръ Матвеевичъ Мамоновъ, бывшій мой товарищъ.

Въ 1786 году С. К. Вязмитиновъ ${ }^{95}$ ), бывшій тогда бригадиромъ въ Вологодскощъ пъхотномъ полку и квартировавшій въ Могилевъ, женился на моей сестру Александрб Нпколаевнъ; зять мой представиль мнъ, какое несчастіе быть майоромъ и не знать служоб, тто, когда я буду опредъленъ въ польъ, т0 начальниками не буду уваженъ, а еще того хуже, подчиненными презираень, почему предложијъ мнъ̌ учитьсп у него въ полку службъ, на что́ я съ большимъ удовольствіемъ согласился. Въ мирное время полки входили въ лагерь 15 мая, а въ квартиры выходили 15 августа. Я перешель жить въ лагерь и въ первой роть́ считался за прапорщика сверхъ ғомлекта; несъ всю службу простаго офицера, ходиль въ караулы, дежуриль, и капитанъ Дрейеръ, командовавшій первою ротою, въ угодность зятя моего, поступаль со мною таґъ строго въ ученіи, что я вскоръ узналь фронтовую службу; подъ исходъ лагеря, я при полку исправляль майорскую должность и

(Фрейлина Эльмтъ - дочь граба Ивана Карповича Эльщтъ, умершаго въ 1802 году. 0на оставила посльъ себя Записки. - Елисавета Петровна Дивова, жена тайнаго совъ̌тника Андріяна Ивановича. - Грабъ Дмитрій Петровичъ Бутурлипъ, сенаторъ, род. 1763 , ум. 19 ноября 1829 года. 0нъ собралъ знаменитую библіотеку, сгоръвшую въ московскомъ по-

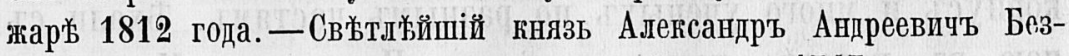
бородко, государственный канцлеръ, род. 8 марта 1747 года, умер'ь 6 апрь̆ля 1796. Онъ былъ пожалованъ графомъ Римской имперіи въ 1784 году. $M$. . Л.).

$\left.{ }^{93}\right)$ Сергъй Козмичъ Вязмитиновъ былъ при Александръ I с.-петербургскимъ генералъ-губернаторощъ и въ 1818 году получиль граФское достоинство. Умерт 15 октября 1819 года. Девизъ его герба былъ: путемъ правды и усердія. М. II. 0 супругъ его см. въ Запискахъ Д. Б. Мертваго. 
могъ уже безъ стыда быть опредълленъ въ полкъ и съ честію удержать свое званіе.

Въ 1786 году отобраны были отъ малороссійскихъ монастырей деревни; изъ оныхъ набраны были рекруты и сформированы десять гренадерскихъ полковъ четырехъбатальонныхъ. Сибирскій гренадерскій порученъ былъ зятю моему, и я въ оный былъ опреджљленъ. Въ Бблоруссіи полки были подъ начальствоиъ князя В. В. Долгорукаго ${ }^{96}$ ), котораго команда была очень для молодыхъ людей пріятна, ибо вмъсто строгихъ сщотровъ, онъ желаль только въ лагерь праздников'ь, забавляя тьй свою жену, на которой тогда только-что женился. Всегда заранье извъщалъ, когда который полкъ будетъ смотрбть, и для того полковники приготовляли праздники, иллюминаціи и фейерверки: одинъ другаго хотьли перещеголять. Но болье всъхъ въ томъ успьљљ Кинбурнскаго драгунскаго полка полковникъ Юшковъ: онь построиль галлерею, въ которой было около четырехъ тысячъ восковыхъ шкаликовъ. Ћаковъ же полкь быль въ ученіи, унолчу, пбо, употребя лагерное время на устроеніе такой галыереи, мало оставалось на ученіе.

1787. Въ 1787 году императрица предприняла путешествіе въ новопріобрґтенныя свои области, въ которыхъ начальствовалъ князь Г. А. Потемкинъ. Государыня отправилась ивъ Петербурга въ 1 день января. Свиту ея величества составляли: часть ея двора, ея канщелярія, дипломатическій корпусъ и много ученыхъ по разнымъ частямъ. Фхали съ нею въ кареть: камеръ-фрейлина Протасова, Мамоновъ, австрійскій посланникь графъ Кобенцель ${ }^{97}$ ), Л. А. Нарыш-

96) Князь Василій Васильевичъ Долгорукой род. 1752 года, умеръ 1812, дъйствительнымъ тайным'ь совйтникомъ. Онъ былъ сынъ князя Долгорукова Крымскаго. 0 женъ̌ его смотри прим. 90. М. .І.

97) Графъ Лудвигъ Кобенцель род. $21 / 10$ ноября 17э3, ум. $22 / 10$ Февраля 1809. Онъ былъ посломъ въ Россіи съ 1779 по 1797 годъ. $M . \mathcal{I}$. 


\section{$-61-$}

кинъ, оберъ-юамергерь Шуваловъ $\left.{ }^{98}\right)$; въ посльвдуюей за нею кареть были: англійскій министрь Фицъ-Гербертъ, французскій графь Сегюрь $\left.{ }^{99}\right)$, генераль-адъютанть графъ Ангальть ${ }^{100}$ ) и графъ И. Г. Чернышевь. Потомь чрезъ день мънялись въ карету императрицы: Фицъ-Герберть и графь Сегюрь съ Нарышкинымъ и Шуваловым'ь.

Путешествіе ея было чрезь губерніи Новгородскую, Смоленскую, Могилевскую, Черниговскую до Кіева. Генералъгубернаторы, губернаторы съ предводителями и почетными дворянами на границь каждой губерніи встржчали и провожали до сльдующей. Въ Мстиславьы могилевскій преосвященный Георгій привьтствоваль ее ржчьо, по превосходству которой здысь поставляю ее въ подлинникь ${ }^{101}$ ).

98 Иванъ Ивановичъ Шуваловъ, основатель Московскаго университета, род. 1727 г., ум. 1797 г. $M$. ..

99) Графъ Јудвигъ Филипгъ Сегюръ, извъстный писатель, род. 11 декабря (30 ноября) 1753 г., ум. ${ }^{27} / 1$ августа 1830 г. $M$. I.

100 ) Графъ Өедоръ Евстафьевичъ Ангальть, генеральь-горучикт, род. 10 мая 1732 г., ум. 2 мая 1794 года. Онъ встуниль въ русскую службу въ 1783 году, прослуживши до того въ Пруссіи и Саксоніи. Онъ извъстенъ особенно отличнымъ управленіемъ съ 1786 года сухопутнаго шляхетскаго кадетскаго корпуса. $M . . I$.

101) Пресвйтль̌̆йая императрица! Оставимъ астрономамъ доказывать, что земля вкругъ солнца обращается или солнце обращается вокругъ земли. Наше солнце вкругъ насъ ходитъ и ходитъ для того, да мы въ благополучіи почиваемъ.

Исходиши, нилосердная монархиня, яко женихъ отъ чертога своего, радуешися, яко исполинъ, тещи путь. Оть края моря Балтійскаго до края Евксинскаго шествіе твое: да тако ни единъ изъ подданныхъ твоихъ укрыется благодътельныя теплоты твоея, хотя же мы и покоимся твоимъ безпокойствіемъ, и негорькими хожденіями твоими сидимъ сладко всякъ подъ виноградомъ своимъ и подъ смоковницею своею, яко же Израиль во время Соломона: однако солнечному цвъ̆ту подобясь, туда и очи и сердца наши обрашаемъ, амо же теченіе твое.

Тецы убо0, о солнце наше! спьшно тецы исполинскими стопами во всъхъ твоцхъ благонамьреніяхъ; къ западу только жизни твоея не 
Я былъ наряженъ отвести роту въ Кричевъ для гараула ея величества; какъ скоро государыня изволила прибыть ${ }^{102}$ ), я явился пъ генералъ-адъютанту, генерал'ь-поручику графу Ангальту. Нельзя умолчать о семъ оригиналъ. Думая, по моему провванію, что я ны̆мецъ, сталъ онъ-было говорить со мною по-нъмецви, но узнавъ, что я не говєрю, то спросиль по-французски, гдњ караульная, и приғазалъ, ттобы я его въ оную проводиль. Пришедъ туда, началь онъ съ каждымъ гренадеромъ здороваться; самымъ смьљшнымъ нъ̆мецкимъ выговоромъ затвердиль онъ наизусть нъ̈сколько вопросовъ по порядку, какъ-то: «Здорово, мои други, кақъ вы называетесь? кой городъ? женаты ли вы? им'еете ли дъти? много ли сыновей? много ли дочерей?» и несмотря на отвътъ, что холостъ, все продолжалъ отъ начала до конца свои разспросы; потошъ браль каждаго руку; одинь гренадеръ, думая, что хочеть пробовать его силу, такъ ему сжаль его руку, что бъдный графъ почти со слезами съ трудомъ отняль у него.

Ввечеру приғазаль мнъ спросить отца поего: есть ли туть пожарныя трубы и прочія пожарныя орудія? Я, по приказанію его, спросилъ батюшку, на что́ онъ мнґ̌ отвъ̌чалъ: “Доложи графу, тто это партикулярное мъстечко, и никакой полиціи нйть; но я приказалъ ғапитану-исправнику изготовить ны̆сколько бочекъ съ водою, собрать народъ и поставить близь кухни». Что̀ я его сіятельству и донесь.— ВВедите меня туда». Я, зная гдљ кухня, повель его въ сопровожденіи караульнаго капитана Роштейна. Каюь у кухни всего того не был0, то я побъжаль отыскивать;

спьшши. Въ семъ 60 случаґ, яко же Іисусъ Навинъ, и руки и сердца наши простирая къ небу, возопіемъ: стой солнце, и не движись, дондезе вся великим'ъ твоимъ намъреніям' противныя торжественно побъдиши.

102) Кричевъ принадлежалъ князю Потемгину. Государыня прибыла туда 19 января. 
Јишь только я нь̆сколько щаговъ отойду, оेъ тотчасъ посылаль за мною Роштейна; лишь только я кь нему появлялся, онъ спрашиваль: “Où sont les pompes? $\left.{ }^{103}\right) »-($ Toтчасъ, ваше сіятельств 0 ». Наконець, по многомь тщетномь бъьганіи, принужденъ былъ сказать, что ничего не нашель. Туть онъ мнъ сдъ̌лаль добрый окрикь, для чего я въ точности не исполниль его приказаніе, и взяль меня за руку. “Пойдемъ, сказаль онъ,-я васъ поведу къ императрищ' и покажу ей, какихъ она исправныхъ имъетъ въ своей арміи штабъ-офицеровъ». Я насилу могъ его упросить, чтобъ онъ меня простиль. Туть новая бъда: онъ потребоваль мою записную книжку, и своею рукою хоть্ّљ вписать мою неисправность для урока; но какъ у меня на тотъ разъ книжки не случилось, то снова обременилъ меня выговорами; наконецъ, приказаль мнъ, чтобъ я не прежде легъ спать, пока не приведу все въ порядоюь.

Однакожь я въ тощъ не почитаю себя виновнымъ; мнь приказано было спросить, гдњ пожарные инструменты, что́ я и исполнил'ь. Увидя, что бывшій прусской службы графъ шутокъ не любиль, отыскаль я собранныхъ исправникомь людей и множество бочекъ съ водою; все то было готово, только не въ назначенномъ мъ̌сть. Часа за три до свьта, его сіятельство просиль меня къ себь, и я съ большимъ торжествомъ повель его и показаль мою исправность.

Посль чего онъ быль ко мнъ милостивъ и, по моей просьбъ, выпросиль у оберь-камергера И. И. Шувалова, чтобы меня съ караульными офицерами представиль государынге прежде другихь, дабы офицеры усштыли выйдти къ ружью, вогда императрица отправится: ибо многіе, квартировавшіе въ Могилевской губерніи военные чиновники прибыли въ Кричевъ представиться ея величеству. Между прочими былъ туть Рижскаго карабинернаго полка бригадир' Хомутовъ

$\left.{ }^{103}\right)$ Т. е. гд⿱⺊口 бочки? 
съ его полка штабъ-офицерами. Оберъ-камергеръ поставиль меня съ моими офицерами у самыхъ дверей, въ поторыя государынь надобно было выйдти, такь чтобъ я первый могь быть ей представленъ. Но бригадирь Хомутовъ, какъ скоро двери отворились, выступиль передо мною; государыня, по названіи его оберъ-камергеромъ, подала ему ручку, и отворотнсь оть него, довольно громко спросила: «Не тоть ли это Хомутовъ, который, бывши еще унтеръ-офицеромъ конной гвардіи, провозиль потаенно товары мимо таможни?» Дьйствительно онъ быль самый. Тњщъ моя суетность была вознаграждена, что онь перебиль меня быть первымь представленнымъ.

Воть гдъ пое самолюбіе претерпьло униженіе: въ день пріъзда государыни увидъљъ меня камердинеръ ея, Захаръ Ћонстантиновичъ Зотовъ, ћоторый быль уже въ полковничьемъ чиньь; а когда я былъ адъютантомъ у свьтльйшаго князя, тогда онъ был'ь камердинеромъ при немъ. Онъ спросиль меня, быль ли я у Мамонова, бывшаго моего товарища? Но какъ я сказаль, что не быль, то совйтоваль мнж къ нему явиться. Я посльдоваль его доброжелательству; ежели пользы никакой не получу, то по крайней мърж при многолюдствљ покажу, что я знакомъ фавориту. A выступиль съ гордымъ и самонадъяннымъ видомъ впередъь и поклонился ему; но виьсто того, чтобъ обратить на меня благосклонное вниманіе, онъ взглянулъ на меня съ презрьніешь и отвратился. Әто было низкое мщеніе за мою съ нимь бывшую ссору; но признаться, очень мнъь было больно предо всъми быть такъ унижену ${ }^{104}$ ).

Ииператрица продолжала путь до Кіева, гдґ пребывала до вскрытія отъ льда Днбепра. Когда наступила весна и свободное по Днъ̆пру открышось плаваніе, ея величество

104) Ћъь сожальнію авторьь ничего не сообщаеть въ своихъ запискахь о причинахъ и обстоятельствахъ ссоры своей съ Мамоновымъ. $M$. $\boldsymbol{I}$. 
отправилась водою, на построенной для сего Флотиліи, до Днъпровскихъ пороговъ, со всъчъ дворомъ и министрами. Путемъ симъ управляль свътлтйшій князь Григорій Александровичь. Король польскій Станиславъ Августь ${ }^{103}$ ) имъัль съ императрицею, доставившей ему горону, свиданіе въ

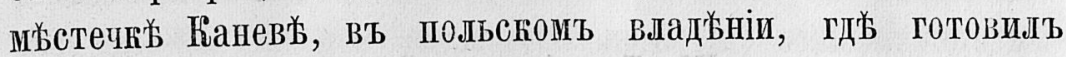
большой праздникъ. Императрица не разсудила съъзжать на берегъ съ своей яхты, но дворъ ея быль великольнно угощаепъ.

У порога Кайдағи императорь Іоситъ II встрботиль императрицу и, вмъсту съ нею, сухимъ путемъ отправился на полуостровъ Крымъ. Въ Севастополь былъ построенъ великоль̆ыный дворецъ, изъ оконъ котораго была видна вся гавань; по прибытіи ея, сожженъ былъ огромный фейервергъ, и весь большой Флотъ быль иллюминованъ. Императрица наименовала свйтльйшаго князя Таврическимъ.

На возвратнонъ пути, въ Полтавъ собранъ былъ корпусъ войскъ, гдъ производились маневры, түь самые, которыми въьчно достойный памяти потошства император' Петрь Великій побъдилъ Карла XII и возвель Россію на ту степень величія, на каковой она нынъ. Іосифъ II получилъ извъстіе o возмущеніи Нидерландцевъ, почему и огпавился восвоясп, а императрица продолжала путь свой чрезь Носкву ${ }^{106}$ ).

105) Станиславъ Августъ Понятовскій, посльъдній король польскій, род. 7 января 1732 г., избранъ королемъ въ сентябрж 1764, отрекся отъ престола въ Гроднъ, въ ноябрь 179 года, умеръ въ Петербургъ̌ 31 января 1798. При имгератрицъ Елисаветь онъ быль въ Россіи въ 1750 годахъ сперва кавалеромъ англійскаго посодьства, а потомъ посланникомъ польскимъ и съ тб̌хъ порь пользовался особымъ благоволеніемъ Екатерины, которой обнзанъ быль потомь престоломъ. $M$. $\boldsymbol{I}$.

${ }^{106}$ ) Государыня не очень жаловала Москву, навывая ее нъ себт недоброжелательною, потому что всъ вельможи и знатное дворянство, получа по службъ какое неудовольствіе и взяв'ь отставку, основывали 
Важнъйшая польза отъ путешествія Екатерины II въ южныя области Россіи состояла въ зағлюченномъ съ императоромъ Іосифомъ II наступательномъ союзъ противъ Турокъ, посльддствіе котораго прославило Россійское оружіе, изнурило Австрію и пагубно было для Турецкой имперіи.

\section{IV. Турецкая война.}

Булгакову ${ }^{107}$ ), нашему министру при 0ттоманской Порть, пригазано было подать ноту, в'ь готорой между прочимь требовано: чтобы Турція позволила имбъть консула въ Варнъ; чтобы признала Ирағлія русскимъ вассаломъ; чтобъ обуздала Татаръ закубанскихъ, безпокоившихъ набжгами гра-

жительство свое въ древней столицй, и случалось между ними пересуживать дворъ, политическія пропсшествія, негодовать на фаворитовъ и вольно говорить о самой императрицй. Какъ Москва старинный город'ь, то улицы ея не прямы, строеніе старое, не по новому вкусу архитегтуры; близь огромнаго дома бывали хижины. Государыня спросила, на другой день своего прибытія, англійскаго министра ФицъГерберта съ насмъшливымъ видомъ:-Comment avez vous trouvé ma bonne ville de Moscou? - Votre Majesté, отвъчалъ тотъ, il n’y a pas une seule ville au monde, qui puisse être comparée à Moscon en beauté.-C'est une ironie?-Non, V. M., c'est la pure vérité, il n'y a nulle part ce que j'ai vu a Moscou: j’ai vu des palais, qui n'ecrasent pas des chaumières auprès d'eux. T. е. «Какъ Вамъ гажется мой добрый городъ Москва?» - «Нъть въ мірь города, Ваше Величество, который быль бы прекраснье Москвы.»-(Вы шутите?)- “Нътъ, Ваше Величество, сущая правда; я нигцъ не видаль того что̀ въ Москвъ:: дворцы въ ней не давятъ собою близь находящихся хижинъ).

Принщъ де-Линь спросиль имгератрицу: «Отчего, В. В., въ прожздъ мы видъ̌ли, что нб̌которыми губернаторами вы были довольны, а потому изъявляли имъ ваше благоволеніе, а нькоторыми были недовольны, и вы имъ ничего оскорбительнаго не скавали?»- «Потому что,

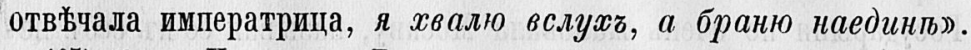

107) Яковъ Ивановичъ Булгаковъ, дъйствительный тайный совьтникъ, ум. 7 іюля 1809. Онъ извъьстенъ гакъ дипломать и писатель. $M . \mathcal{I}$. 
ницы Россійской имперіи, чтобъ объяснила 0 военныхъ св0ихъ приготовленіяхъ, и чтобъ отвътъ на все это данъ быль безъ замедленія ${ }^{108}$ ).

Диванъ виъсто отвъта объявилъ войну Россіи, 5 августа, и заключиль нашего посланника Булгакова въ Семибашенный замокъ. По полученіи сего извъстія, императрица вы-

108) Векоръ, по прибытіи двора въ Петербургъ, по случаю войны было сдъзано распоряженіе всену генералитету, кому въ которой арміи быть и какими частями командовать. Сей списогъ, сочиненный свڤ̆тлҺйтимъ нняземъ, императрица утвердила. А. В. Суворовъ не былъ внесенъ въ него, ибо свб̆тльйшій ннязь, по странностямъ его, почиталъ его человькомъ ничтожнымъ, а по чину его должно было дать ему преимущество передъ многими, по службъ считавшимися ниже. Суворовъ, узнавъ . томъ, пріъхаль въ Петербургъ, прямо явился иъ императрицъ, и съ плачевнымъ видомъ сказалъ: «Государыня, я прописной). - Какъ это? спросила императрица. «Меня нигдљ не помъстили съ прочими генералами и ни одного капральства не дали мнг въ команду». Императрица оскорбилась на князя Потемкина и тотчасъ послала за нимъ. Посланный разсказалъ князю, по какому случаю за нимъ былъ посланъ, почему, бывъ предваренъ, онъ съ готовымъ отвћтощъ пошелъ. Какъ скоро онъ вошелъ, государыня недоводьнымъ голосомь сказала: «Такъ, князь, вы извъ̌стнаго, отличнаго, заслуженнаго генерала въ поднесеннощъ вами мнъ̆ спискъ пропустили?»-Отъ того-то, отвъьчалъ князь, что вашену величеству онъ такъ извъ̌стенъ, я и не вписалъ его съ прочими, чтобы вы сами изволили назначить, гдъ и канъ вамъ будетъ угодно. - Въ сіе же время и М. $\theta$. Каменскій пріъхалъ. Государыня черезъ нъ̆скольго дней по его прибытіи послала ему $\breve{5,000}$ руб̆лей золотомъ; онъ счелъ то за маловажный подарокъ, и въ Лътннемъ Саду каждодневно дъ̆лалъ завтрагъ, ловя встрбъчнаго и поперечнаго, пока не истратилъ всъ жалованныя деньги и уб̆халъ. А Суворовъ поступилъ иначе: когда памерълагей привезъ ему такой же подарокъ, онъ вынуль одинъ имперіялъ и отдавъ его ғамеръ-лакег, сказалъ: “Доложи государынъ, что Суворовъ по ея милости очень богатъ, и на что мнґ такая груда золота, а осмълился одинъ имперіялъ вынуть, чтобы дать тебъ). Посльь того поъхаль изъ Петербурга. Императрища вслььцц за нимъ послала ему 30,000 р.; эту сумму онъ приняљ безотговорочно. 


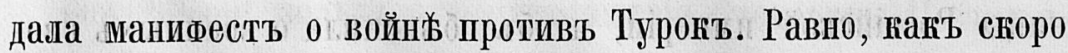
дошло иввьстіе до императора Іосифа, такь и онъ объявилъ войну Оттоманской Порть.

Составлены были двъ̌ арміи: Украинская, подъ командою фельдмаршала графа Петра Александровича Румянцова-Задунайскаго, которая должна была вступить въ Польшу и приблизиться къ Днъсстру; правый Фланг'ь оной арміи составляль корпусъ подь командою генераль-аншефа, графа Ивана Петровича Салтыкова ${ }^{109}$ ), центрь арміи составляль корпусь генераль-аншефа Эльшта, львый флангь составляль корпусь генераль аншефа Михапла Өедотовича Каменскаго $\left.{ }^{110}\right)$. Вторая армія Екатеринославская, состояла подъ командою фельдмаршала свъттлйшаго князя Григорія Александровича Потемьина-Таврическаго, которому назначено было съ наступаюею кампаніею атаковать Очаков'ь. Генераль-аншефъ Александръ Васильевичъ Суворовъ тогда командовалъ въ Ћинбурнь.

Зять мой С. Ћ. Вязуитиновъ пожалованъ быль генералъмайоромъ, приказано ему было принять Бълорусскій егерскій корпусъ, изъ четырехъ батальоновъ состоящій, на мйсто заболььвшаго шефа того юорпуса генералъ-майора Фаминцына; Сибирскій полкт вельно было принять полковнику князю П. М. Дашкову, который предъ симъ командоваль Днъпровскимъ мушкатерскимъ полкомъ; но большею частію люди сего полка посажены были на флотилію для путешествія императрищы къ Херсону, и тамь размьшщены по другимъ полкамъ. Князь Дашковъ приняль полкъ на походь въ Кіевъ̌, откуда польъ пошель въ Польшу, въ корпусь графа Салтыкова, котораго квартира была въ мъ̌стечк'ь Янов.

109) Графъ Иванъ Петровичъ Салтыковъ, фельдмаршалъ и тлавнокомандующій въ Москвъ, род. 1730 , ум. 14 ноября 1805 г. $M$. JI.

110) Графъ Михаиль Өедотовичъ Тіаменскій, фельдмаршалъ, род. 1738, уо̆шть в'ь своей деревн'ь 12 августа 1809 года. M. II. 
Ћогда полкъ получилъ повельніе идти въ походъ, почтенный мой отецт, благословя меня, сказаль: “Увъренъ, что ты не обезчестишь родъ нашъ своимъ недостойнымъ поступкомь, и лучше я хочу услышать, чтобы ты быль убить, нежели бы себя осрамиль, а притомь приказываю тебъ: ни на что не напрашиваться, а чего требовать будеть долгь службы, исполняй ревностно, усердно, точно и храброљ. Туть мы оба прослезились; пощъловавъ его руку, съ восхищеніепь съль я на коня и съ полкомъ выступиль, Дълая планы отличиться геройски и строплт воздушные зашки.

1-го октября Турки атаковали Кинбурнъ. Суворовъ не приказаль противиться высадкь, далъ имъ время сдьлать ньскольк0 ложементовъ, и какъ уже увидъљ'ь ихъ приблизившихся шаговь на двъсти, для штурма крбъпости, тогда напаль онъ. на нихъ съ своими войсками. Турки безпрестанно съ Флота получали новыя подкрьпленія, положеніе нашихъ войскъ было весьма опасно; сраженіе сдъ̌лалось общее, и такъ объ стороны перемьшались, что артиллерія принуждена была остановить свое дйиствіе; храбрость нашихъ поколебалась; уже было начали отступать; наконець пришло къ Русскипь подкрьпленіе около трехъ соть человъкъ, и сіе малое число рьшшило сраженіе. Турки прогнаны, въ 10 часовь ночи побжда была одержана. Большая часть Турокь убита, а еще больье потонуло; палое только число спаслось на суда.

Еще въ сумерки Суворовъ быль раненъ въ львое плечо; онъ потеряль много крови, и не было лекаря перевязать рану. Ћовачій старшина Кутейнпковъ привель его къ морю, вымыль рану морскою водою и, снявъ свой платокъ съ пеи, перевязаль ииъ рану. Суворовъ съль на коня и опять возвратился командовать. Тогда же генераль-майорь Рекъ быль раненъ; наша потеря была очень значительна.

Эта первая побъда въ сію войну ть̌ы была важнъее, что оною уничтожены намъренія Турокъ - взять Кинбурнъ, привесть себя въ состояніе напасть выгодно на Херсонъ и 


\section{$-70-$}

Крымъ и истребить нашу флотилію. За сію побъду Суворовъ награжденъ былъ андреевскимъ орденомъ.

Свъ̆тлййшій князь, опасаясь вторичнаго нападенія на несобравшуюся еще его армію, просиль императрицу, чтобы на случай могъ онъ употребить одинъ корпуеъ Украпнской арміи. Государыня приказала фельдмаршалу графу Румянцову, чтобы, по способности одинъ корпусъ его арміи состоялъ подъ ордеромъ св'ътльйшаго князя до открытія кампаніи, почему фельдмаршалъ и приказаль генералу Каменскому явиться Къ князю.

Каменскій повхалъ въ Елисаветградъ, гдъ тогда была главная квартира его свътлости; но гаґъ онъ предвидъљљ, чт0 больше будетъ выгодъ въ арміи свйтльйшаго князя, чъ̆ыт подъ командою устаръылаго фельдмаршала, то и просилъ князя, чтобъ онъ его корпусъ взяль совежнъ въ свою армію, сказавъ: “ибо съ тьхъ поръ, какъ я состою подъ ордеромъ вашей свътлости, корпусь мой претерпьваетъ во всеиъ недостатки, какъ-то: въ свое время не получаю ни аммуниціи, ни жалованья, ни провіянта». Князь отвйчалъ: «очень хорошо; отправьтесь въ свой корпусь (который расположенъ быль въ Уманъ), гдъ узнаете 0 вашемъ желаніи ). Ћакъ скоро Каменскій отправился, князь всльдь за нимъ отправиль курьера, требуя оть него изъясненія письменнаго 0 томъ, чтоे онъ докладываль ему о претерпґъваніи нуждъ его корпуса. Каменскій, нехотя, долженъ быль сіе исполнить, хотя съ нжкоторыми увертками. Князь, получа отъ него требуемое, отправиль къ фельдмаршалу рапорть Каменскаго, въ предосторожность отъ сего коварнаго человйка. Князь не любилъ подлыхъ людей, и съ тйхъ поръ онъ никогда его не употребляль, да и графъ Петръ Александровичъ поступалъ съ нимъ не лучше. Вотъ что̀ выиграль Каменскій своею интригою $\left.{ }^{111}\right)$.

111) Еще быль случай, въ которомъ ннявь Г. А. Потемгинъ показалъ, 
До открытія кампаніи, войска въ занимаемыхъ квартирахъ были погойны; туть я увиды̆лъ разницу между бывшииъ и новымъ моими начальниками. Зять мой вел'ь служ-

что не любилъ льстеповъ и подлецовъ. Извъстный по сочиненіямъ своимъ, Денисъ Ивановичъ Фонъ-Визинъ былъ облагодытельствованъ Иваномъ Ивановичемъ Шуваловымъ; но, увидя свои пользы быть въ милости у свъ̌тльйшаго, не взирая на давнюю его большую непріязнь съ Шуваловымъ, перегинулся къ княвю, и въ удовольствіе его много остраго и смъшнаго говариваль насчеть бывшаго своего благодъ̌теля. Въ одно время, князь былъ въ досадъ и сказалъ насчетъ нъ̆которыхъ лицъ: «какъ мнъ надоб̆ли эти подлые люди). «Да на что же вы ихъ къ себъ пускаете, отвйчалъ Фонъ-Вивинъ, велите имъ отказывать».- - Правда, сказалъ князь, завтра же я это сдъълаю». - На другой день Фонъ-Визинъ пріъззжаетъ къ князю; шпейцаръ ему докладываетъ, что князь не приказалъ его принимать. «Ты върно ошибся, сказалъ Фонъ-Визинъ, ты меня принялъ за другаго».- - «Нътъ, отвъ̌чалъ тотъ, я васъ знаю и, именно, его свътлость приказаль одного васъ только не пускать, по вашему же вчера совьтуу). Л. Э.

Примли. Н. В. Путаты. Княвь Вявемскій, въ сочиненіи своемъ (Фонъ-Визинъ), упоминаетъ объ этомъ случаъ, какъ о преданіи, сохраненномт злорьчивою молвою, съ тою толью разницею, что у него говорится 0 передражниваніи не ПІувалова, а графа Н. И. Панина, который былъ, какъ извъ̌стно, начальникомъ и благодътелемъ ФонъВизина. Князь Вяземскій старается оправдать Фонъ-Визина и, вотъ его слова: аСношенія Фонъ-Визина съ графомъ Петромъ Ивановичемъ продолжались и посль смерти графа Никиты Ивановича Панина. Въ семъ обстоятельствъ ваключается, по нашепу мньнію, оправданіе ФонъВизина въ нареканіи, которымь тяготится память его. Объяснимся..... Разсказываютъ, что Фонъ-Визинъ, искавъ милости въ князъ Потемкинъ̌, быль готовъ предать ему любовь и благодарность свою къ графу Никить Ивановичу Панину, котораго кн. Потемкинъ не любилъ; чт0, забавляя вельможу, передражнивалъ онъ передъ нимъ своего начальника и покровителя; но что Потемкинъ, по своенравію и непостоянству прпхотей своихъ, скоро наскучиль искательствами новаго поклонника и выжидаль только случая проводить его оть себя съ оскорбленіемъ. Случай сей скоро подоспьль: однажцы жаловался онъ предъ Фонъ-Визинымъ на толпу докучников'ъ и льстецовъ, которые безъ 
бу, какъ должно бы наблюдать каждому; вопервыхъ, военная дисциплина строго хранилась, чинъ чина почиталъ, но благородная связь была между порпусомъ оФицеровъ; порядокъ канцеляріи въ отчетахт суммъ, жалованья, аммуниціи, провіянта и фуража приведенъ был'ъ въ точность, обозъ былъ псправный; полковыя лошади были добрыя, полк' учился превосходно, въ эволюціяхъ опицеры были наметаны, солдаты безъ изнуренія выправлены, одъъты безъ излишней вытяжки, хорошо. Во время похода въ Россіи и

отбою өсаждаютъ его. Фонъ-Визинъ совь̆товалъ ему въ семъ случағ сльъдовать примъру государственныхъ людей въ другихъ земляхъ, которые въ кабинетахъ своихъ недоступны для праздношатающихся искателей. Потемгинъ объщалъ воспольвоваться совйтощь его, и туть же далъ приказаніе впредь не впускать къ себъ Фонъ-Визина. Ciе оскорбленіе не могло-бы не сдълаться гласнымъ и двуличность ФонъВизина обнаружилась бы скоро. Положимъ, что начальникъ его и не провъдалъ бы 0 томъ, потому что отношенія начальниковъ къ подчиненнымъ часто походять на отношенія мужей къ женамъ: ть' и другіе узнагтъ изъ посль̌днихъ въ городъ, что они обмануты; но какъ могь бы брать министра не узнать стороног о случившемся? а узнавъ, какъ могъ человъъъ, подобный графу Петру. Ивановичу Панину, оставаться въ пріявни съ предателемъ лукавым и неблагодарнымь? Изь всего әтого разсказа можно допустить только два обстоятельства. Немудрено, чт0 Фопъ-Вивинъ, который имеัљъ даръ передражниванія, представиль въ лицахъ и начальника своего-шутка невинная! Ещце сбыточно и то, что князь Потемкинъ, извъстный неровностію нрава своего, то обходительный, то неприступный, т0 ласковый до обольщенія, то высокомърный до обиды, сперва приласкалъ Фонъ-Визина, уважая умъ его, а посль⿱宀 охладъ̌зъ къ нему и даже радъ быль оскорбить въ немъ человьъа, преданнаго сановнику, коему онъ не доброжелательствовалъ. Сіи предположенія, покрайней мърь, основаны на въ̌роятности; но все прочее, предосуцительное для чести Фонъ-Визина, оспоривается приведенными здъ̌сь свидььтельствами и должно быть приписано къ выдумкамъ клеветыр.-С.м. Фонг-Визинб, сочиненіе киязя Петра Вяземскаго. Спб. 1848 थ., стр. 111, 112 и 113.

(Денисъ Ивановичъ Фонъ-Визинъ род. 3 ащрљля 1745 г., ум. 1 декабря 1792 г. M. Л.). 
Польшь ни одной подводы ни подъ накишъ видомъ ниғто не смъљљ взять, солдаты несли на себъ всъ тягости и даже шанцевый инструментъ ${ }^{112}$ ). Словомъ, полюъ могъ быть во всъхъ частяхъ образцовымъ въ армік. При гомандованіи же полкомъ княземъ Дашковымъ, солдаты во многомь претерпъвали нужды, для продовольствія провіянта и фуража онъ принималь деньгами и задерживаль ихъ; то же случалось и съ жалованьемъ; хотя чрезъ ныъкоторое время оно и отдавалось, но не въ свое врешя; лошади были худо нақормлены, отчего въ переходахъ въ Польшъ бралось множество подводъ, почему безпрестанно на полюъ были жалобы, а во время кампаніи гъ полковому обозу наряжались солдаты, чтобы въ трудныхъ мъстахъ пособлять взв0зить на горы. Чтобы нижніе чины не роптали, князь далъ пополвновеніе къ воровству, чъичъ по времени Сибирскій полкъ получиль дурную молву; полковникъ пмъљљ пристрастіе къ нь⿻上丨торымъ опицерамъ, за то другіе были въ загонь и претерпьвали разныя несправедливости.

1788. Въ 1788 году, въ апръль, зять мой Вязиитиновъ съ 4 батальонами, 4 әскадронами и двумя стами козаковъ посыланъ былъ въ соединеніе съ Австрійцами для закрытія Буковины, угрожаемой Турками; но вскоръ возвратился, не ииъвъ никакого дъзла.

Украинская армія образовалась такимъ образомъ: корпусъ состоящій изъ 12 батальоновъ, 12 әскадроновъ, 30 орудій полевой артиллеріи и одного козачьяго Донскаго полға, подъ

112) Многіе полки, проходя по Россіи и Польшь, брали подводы для облегченія солдатъ, тагъ что громъ ружья они ничего не носили. Мы всъ роптали, для чего бы газалось и намъ изнурять своихъ; но пользу уже я увидъљљь во время пампапіи, гогда должно было носить на себъ всъ тягости; не привығшіе гъъ тому уставали до того, что, пришедъ въ лагерь, въ другихъ полкахъ сотнями отставали, а въ Сибирскомъ полку по навыку къ трудамъ ни одного отсталаго не случалось. 
командою генерала графа Салтыкова, въ соединеніи съ австрійскимъ корпусомъ, подъ командою принца Ћобургскаго, долженъ былъ осадить Хотинъ.

Главному корпусу назначено было рандеву Подольской губерніи при мхстечкё Мурахвъ (въ сей корпус'ь Сибирскій полкъ быль назначенъ). Оный горпусъ состонлъ изъ 17 батальоновъ, 10 әскадроновъ кирасиръ, 18 карабинеръ, одного Донскаго казачьяго полка и 30 орудій полевой артиллеріи.

Корпусь генерала Өльмта, состоявшій изъ 12 батальоновъ, 12 эскадроновъ, двухъ Донскихъ казачьихъ полковъ и 30 орудій полевой артиллеріи, долженъ быль перейдти черезь Днъстръ и дъ̌лать поиски надъ непріятелемъ.

Резервный корпусъ, подъ командою генерала Каменскаго, состонлъ изъ 12 батальоновъ, 12 эскадроновъ, одного полка Донскихъ казаковъ и 20 орудій полевой артиллеріи.

Вся армія, ежели была бы въ комплекть, состояла бы изъ 50,$000 ;$ но на лицо, конечно, не превосходила 30.000 человььь.

Какъ въ Украинской арміи не было регулярныхъ легкихъ войскъ, то фельдмаршалъ испросиль повволеніе у императрицы преобразовать четыре полка карабинеръ и назваль ихъ легкоъздными. $\mathrm{y}$ Фельдмаршала съ княземъ Потемкинымъ былъ споръ въ наименованіи войскъ: сперва именовали ихъ легкою кавалеріею, а свътлъйшій князь назваль легкою конницею; графъ назвалъ своихъ легкобздными. Ћогда свъттлйшій князь въ послъдствіи принялъ въ командованіе объ арміи; назвалъ ихъ конными егерями, хотя лошади и вооруженіе оставались т苂 же самыя.

Екатеринославская армія числомъ гораздо была превосходнъе и двинулась къ Очакову. Притомъ подъ непосредственнымъ распоряженіемъ свъьтыйшаго князя состоңль Черноморскій Флотъ и гребная Флотилія. Всъми морскими 
силами управлялъ вице-адмиралъ Н. С. Мордвиновъ ${ }^{113}$ ), флотомъ начальствовалъ контръ-адмиралъ Ушаков'ь ${ }^{1: 4}$ ), имъя подъ собою извъьстнаго Поль-Джонса ${ }^{115}$ ), прославившагося въ американской войнъ. Флотиліею вомандоваль принцъ Haccay ${ }^{116}$ ).

Собравшейся Украинской арміи главный корпусъ полу-

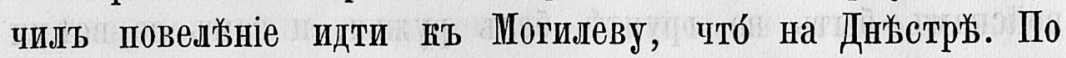
прибытіп туда, на другой день и фельдмаршаль прибыль съ главною квартирою. Генералъ-поручикъ кн. Г. С. Волґонскій ${ }^{117}$ ) вступилъ въ командованіе корпусомъ. Всею артиллеріею арміи командовалъ артиллеріи генералъ-майоръ И. М.'Толстой $\left.{ }^{118}\right)$; инженерами оригадиръ Б. $\theta$. Кнорингъ ${ }^{119}$ ). Генералъ-квартермистромъ былъ Н. М. Бердяевъ, при неиъ генераль-квартемистры -лейтенанты: бригадиръ Медеръ и

113) Грабъ Николай Семеновичъ Мордвиновъ, адмиралъ, род. 17 ашръля 1754 г., ум. 30 марта 1845 года. Онъ прославился умомъ и непоколебимою твердостію характера. $M$.

114) Өедоръ Өедоровичъ Ушаговъ, адмиралъ, родился 1743 г., умеръ 1817. Онъ особенно прославился взятіемъ Корфу въ 1799 г. M. J.

115) Поль-Джонсъ, гонтръ-адмирал'ь, род. въ Шотландіи 6 іюля 1747 г., ум. въ Парижь 18 іюля 1792. 0нъ быль въ русской службъ только одинъ годъ, прославившись до того въ войнъ за ащериканскую независимость. М. II.

116) Принцъ-Нассау-Зигенъ, адмираль, родился 174ٌ, ум. 10 апръля 1808 г. Онъ вступиль в'ь русскую службу въ 1788 году, служивши прежде Франціи. $M$. I.

117) Княิвь Григорій Семеновичъ Волконскій, генералъ отъ кавалеріи, род. 30 января 1742 года, умеръ 17 іюля 1824 г. 0нъ былъ женатъ на дочери посльљдняго князя Репнина (извъ̌стнаго фельдмаршала Николая Васильевича), почелу сынъ ихъ кн. Николай Григорьевичъ Волконскій вазванъ въ 1801 году княвешъ Репнинымъ-Волконскимъ. М. J.

118) Иванъ Матвеевичъ Толстой, генералъ-поручикъ, род. 1746 г., умеръ 15 іюля 1808 г. Сынъ его быль знаменитый генераль, графъ остерманъ-Толстой, недавно умершій. $M$. II.

119) Богданъ Өедоровичъ Кнорингъ, генералъ отъ инфантеріи, род. 1741 умеръ 1836 года. $M . J$. 
полковникъ Филиппи. Дежурнымъ генераломъ фельдмаршгалъ избралъ генералъ-пайора А. Я. Јеонидова. Въ корпусь командовали: кавалеріею генералъ-майоръ В. В. Энгельгардтъ; пьхотою генералъ-майоры гр. Мелинъ и Мельгуновъ; авангардомъ генералъ-майоръ Јасси ${ }^{120}$ ).

На другой день по прибытіи, пельдамаршаль приказаль войскамъ быть во фрунте безъ ружья, и самъ со всыми генералами прибыль къ корпусу; всъ были при появленіи его въ восхищеніи; ни одного не оставилъ онъ штабъоФицера, готорону бы не сказаль чт0-нибудь пріятное. Какъ скоро сказаль солдатамъ: «Здравствуйте ребята!) всъ почти въ голосъ закричали: “Здравствуй нашъ батюшга, графъ Петръ Александровичъ!» Старые солдаты говорили: «Насилу мы теб̆я, нашего отца, увидъъли». Посъдынлый унтеръ-офицеръ, обвъшанный медалями, сказалъ фельдмаршалу: «Вотъ уже, батюшка, въ третью войну иду съ тобою».— «Ну, другъ мой, отвъчалъ графъ, въ четвертый разъ мы виъстьъ съ тобой уже воевать не будемъ».-0бъьхавъ всъ полки, исполненные радостію его присутствіемь, отьжхалъ онъ въ главную свою гвартиру, въ Могилевъ.

Авангардъ ${ }^{121}$ ), состоящій изъ пяти баталь0новъ , шести эскадроновъ и Донскаго полка Грекова, переправился чрезъ Днъстръ, а въ то врешя наводили понтонный мостъ.

Какъ скоро пость быль готовъ, весь корпусъ переправился и заняль высоты: пъхота въ двъ линіи, кавалерія въ третьей, а главная квартира за оною. Гренадерскіе полки, какъ-т0: Сибирскій на правомъ флангъ, 1-й и 2-й батальоны въ первой линіи, а $\mathbf{3}$ и 4 -й во второй; на льъ-

120) Морицъ Іетровичъ Јасси, генералъ отъ инфантеріи, ум. 1820 года. $M$. JI.

121) Не пишу чиселт, гогда что происходило, потому что не помню. 
вомъ Флангъ⿱⺊口 былъ Малороссійскій гренадерскій, въ кот0ромъ фельдмаршаль быль шефомъ. Первыми двумя батальонами въ лагеръ начальствоваль самъ полковникъ, а какь подполковникъ откомандировань быль для командованія своднымъ гренадерскимъ батальономъ въ авангардъ, т0, какъ старшій по нешъ въ лагеръ, 3-мъ и 4-иъ батальонами полка командовалъ я; ғањъ же скоро горпусъ двигался, т0 полюъ соединялся вмъ̌сть.

На другой день выступиль горпусъ в'ь походъ. Предъ выступленіешъ, когда лагерь быль снятъ, полки выстроились, знамена были развернуты. Фельдмаршаль проъзжаль мимо планга командуемыхь мною батальоновъ; я сдъљлаль ему на карауль и поспакаль пь нему на встръчу. Но представьте мой ужасъ! Фельдмарпаль на меня кричаль самымъ страшныиъ голосомъ; видъ его представляль, чего вообразить невозможно: ноздри раздувались, глаза яростно сверкали. Какь скоро я услышаль этоть голосъ и увидъыль страшный его видъ, то такъ оробъль, что не слыхаль ни одного его слова. Дежурный генераль', подскакавъ ко мнъ, приказалъ кошандовать: на плечо! Я едва могъ выговорить. Посль чего опять подъъхаль онъ ко мнъ и спрашиваль оть имени фельдмаршала: «Кағъ я осмъзлился отдать ещу честь!” Я отвъчалъ, что считаль то долгомъ. Но онъ мнъ сказалъ: «Вчера быль отданъ пригазъ, что гогда фельдмаршаль будеть прожзжать мимо полковъ или карауловъ, никогда бы не отдавали еюг чести».отвъччаль, что приказа сего не слыхаль. Когда дежурный генераль донесъ о сказанномъ мною, фельдмаршаль по-

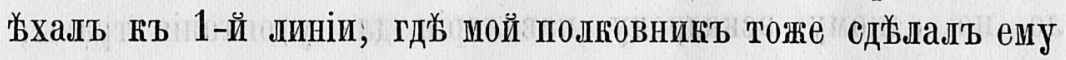
на нараулъ. Фельдмаршаль дъылаль таковое же взысканіе; но каюь полковникъ отвъчаль, что приназа того не слыхалъ, то фельдмаршаль, обратясь къ ннязю Волконскому, сказалъ: “Князь Григорій Семеновичь, я вамъ приказаль?» На что тоть отвъчаль, что и онъ приказаль. Но полков- 
ниґъ утвердительно донесъ графу, что въ Сибирскомъ полку сей приказъ не объявленъ. Фельдмаршалъ приказаль дежурному генералу об́ъ̌хать всъ полки и спросить, въ которыхъ полкахъ объявлено сіе приказаніе? Между ть̆мъ весь корпусъ стоялъ въ ружьљ. Дежурный генералъ, справясь, донесъ, что ни въ одном' полку не было того объявлено. Тогда фельдмаршаль съ великищъ гнйвомъ сказаль Волконскому: «Господинъ генералъ! ежели вы впередъ забудете исполнить мое приказаніе, я васъ поставлю передъ взводъ гренадеръ съ заряженными ружьями, а теперь поॐзжайте Ћъ господину майору Энгельгардту и скажите ему, что онъ исполнилъ свою должность, что я его благодарю, и что выговоръ, сдй.ланный ему, къ вамъ относится». Х0тя его сіятельство и подъъзжалъ по мнъ, но приказанное фельдмаршаломъ мнъ сказать не объявилъ; однакожь пое удовлетвореніе всь̌мъ стало извъстно, ибо главнокомандующій былъ огруженъ всъии генералами и всъмъ штабомъ, къ главной квартирґ принадлежащимъ.

Порядокъ марша каждаго перехода быль таковъ: за авангардомъ шли всегда наряженные на завтрашній день въ караулъ, т. е. всъ пъхотные пикеты съ шанцовымъ инструментомъ; всъ отъъзжіе пикеты гавалерійскіе съ дежурными штабъ-офицерами, съ генѐралъ-квартермистромъ и квартермистрами отправлялись занимать лагерь, и когда корпусъ вступалъ въ оный, то всъ уже караулы были на своихъ мьсстахъ, и цйпь разставлена. Во время похода артиллерія составляла среднюю голонну, по сторонамъ ея двъ пъхотныя колонны; передъ каждой гомандировано было по одному эскадрону кавалеріи для утоптанія травы; по сторонамъ пьхотныхъ колоннъ были двъ кавалерійскія, съ фланговъ которыхъ шла ғавалерійская цьйь. 0бовъ тянулся въ двъ веревки, а иногда и въ четыре, ежели позволяло мъсто; за онымъ вагенбургъ.

Бывшіе того дня полевые пьхотные пикеты съ отъъз- 
жими караулами оставались на своихъ месстахъ по выступленіи корпуса; дежурные штабъ-офицеры формировали оные въ батальоны и эскадроны, и составляли аріергардъ.

Ћогда вступали въ лагерь, то каждый батальонъ подходиль къ львому флангу своего лагеря, а кавалерійскіе полки къ лььвому флангу своихъ полковъ; тогда вдругъ дъланъ быль отбой, и пьхота церемоніальнымъ маршемъ повзводно, а кавалерія поэскадронно, входили въ линію.

Въ походь наряжалось два әскадрона въ конвой къ Фельдмаршалу, и онъ, несмотря ни на какую погоду, верхомъ, въ однощъ мундиръ, до половины марша ьхаль при ґорпусъ. На половинъ̌ приказываль дъ̆лать отбой на часъ времени, а самъ съ главнымъ штабомъ уюзжаль впередъ осмотрџть занятіе лагеря; иногда приказывалъ, по положенію мьста, перемьнить лагерь, п்отомь Һздиль въ авангардъ, осматриваль отъъзжіе пикеты и приказываль, куда посылать партіи. Случалось, что мы, пришедь въ лагерь, уже отдохнули, а онъ только что пріхзжалъ.

Во время марша, фельдмаршаль подъьзжаль къ полкамъ и не дозволяль, чтобъ офицеры сходили съ лопадей; ибо по тогдашнему обряду службы, когда выходили войска въ походъ, то, кромь⿱夂口 дежурныхъ при полку одного капитана и при каждомъ батальонь по одному офицеру, всъ прочіе офицеры могли ьхать верхомъ подль' своего взвода. Солдаты, по желанію, пьли пьсни, и когда графь подъъз-

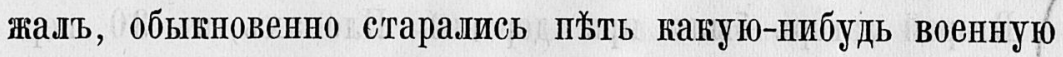
въ честь ему, какъ то: «Ахъ ты нашъ батюшка, графъ Румянцовъ генералъ» и проч. Иногда даваль онъ симъ пьсельникамъ червонца по два, говориль имъ нысколько ласковыхъ словъ, тоже удостоиваль разговаривать съ нькоторыми штабъ и оберъ-обицерами; словомъ, привътливостію своею привлекаль къ себъ всъхъ души и сердца.

Лагерь всегда быль въ двъ линіи: на флангахъ кавалерія, артиллерія батареями между полками, а главная квар- 
тира между двухъ линій. Карауль фельдмаршала состояль пзъ 24 человъкъ при одномъ опицеръ, съ хоромъ музыки и коннвойной команды съ литаврами, съ двумя трубачами; для сигналовъ была въ̌стовая пушка, изъ которой струљляли гъ вечерней зоръ.

с. Пароль и приғазъ отдаваль дежурный генералъ, для принятія котораго должны были быть: дежурный по корпусу полковникъ, подполковникъ и секундъ-майоръ, отъ каждаг0 полка штабъъ-0фицеръ и генеральскіе адъютанты.

къ разводу фельдмаршалъ никогда не выходилъ.

Когда корпусъ не былъ въ походъ, обыкновенно графь выходил'ъ изъ своей ставки или домика, въ большой еринной наметъ, гдъ уже столь быль накрыть, и гдъ̌ генералы и штабъ-обицеры и нъготорые изъ оберъ-оФицеровъ были. Всегда выходилъ онъ въ мундиръ, съ тростью и шляною въ рукъ. 0бходилъ всъхъ туть бывшихъ, и ежели съ

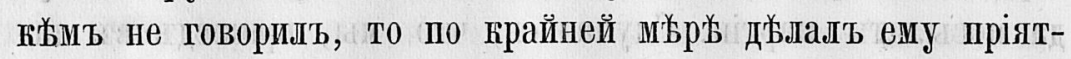
ную нину. Наконецъ пиль водку и закусывалъ, и всъ пто туть были-тоже. Въ первощь часу онъ объдаль; столь накрываемъ былъ на 40 гувертовъ; другой столь въ особливощъ нашеть' для штата его и ординарцовъ, оть каждаго полка наряжаемыхъ по одному оФицеру.

Посль стола фельдмаршаль тотчасъ откланивался; по вечерамъ собирались къ нему генералы и полговники, иногда играли въ коммерческія игры.

Второй лагерь быль при деревнг̆ Плопахъ, въ 30 верстахъ оть Днъстра; тутъ пробыли болье месяца, въ ожиданіи дъйствія осады Очакова и Хотина. Корпусъ генерала Эльмта дошель до Яссъ, не встрџчая нигдъ непріятеля. Фельдмаршаль быль не доволенъ медленнымъ и тактическимъ нъмецкиъ движеніемъ сего порпуса, почему сей генералъ, юогда главный горпусъ подошель къ Цыцоръ (на Прутъ̌, въ 20 верстахъ отъ Яссъ), отправился въ отпускъ и болъе уже въ армію не прібъжаль. 
Iо долгомъ пребываніи въ лагеръ при Плопахъ, отпросилея я къ Хотину на короткое время, посмотрбть осаду и видьтться съ моичъ зятеиъ С. К. Вявмитиновымъ, тогда . ывшимъ въ томъ корпусъ. Онъ съ позволенія графа Салтыкова даль мнге своего адъютанта, чтобъ осмотрбъль я всъ батареи и траншеи, которыя только вели Цесарцы, а наши, пользуясь рвами около Хотина, закрывались оными оть ганонады.

Тогда я увидӝљъ, какъ недостаточно знать одну только Фрунтовую служобу; чтобы значить болье, надобно знать фортификацію и артилерію; и тогда же приняль намюреніе въ зимовыя квартиры заняться сими науками, необходимыми для генерала, а какъ я держался правила, что худой тотъ солдатъ, который не надъется быть фельдмаршаломъ, то и думалъ, что необходимо нужно имътьь познанія, сопряженныя съ сичъ званіемъ. Быль я въ лагеръ у Ав-

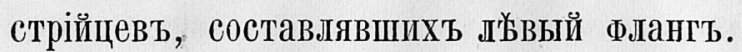

Ни у Австрійцевъ, ни у Русскихъ осадной артиллеріи не было; батареи были въ такомъ отдалепіи, что едва двънадцати-фунтовыя ядра доносило до бруствера, а гранаты ивъ полумортирныхъ единогоровъ никакого дъйствія не проивводили; ночью подвигали батареи безъ всягаго закрытія,

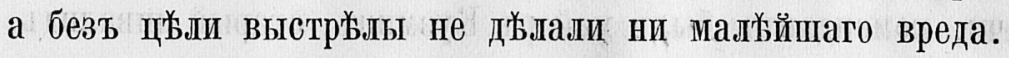

Я чуть было не попался въ пльны и особливымъ чудныпъ образомъ изоавился. У Днъстра былъ во рву егерскій постъ, не допускавшій Турокъ пользоваться хорошею ключевою водою. Осмотрьвь оный, адъютантъ Сергы̆ Кузмича узналь, что ночью, перейдя ровъ, заложена была батарея, которая и была намъ видна, но не зналъ, что пробздъ къ оной по сю сторону рва шелъ очень близко непріятельскаго ретраншамента, а ровъ былъ такъ грутъ, что едва съ тру-

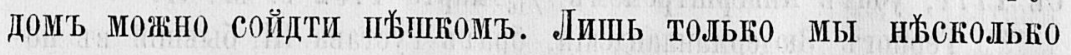
проъхали, какъ егеря стали намъ кричать: сОстерегитесь, Турки васъ видять и намъреваются выйдти изт ретранша- 
мента, чтобы васъ схватить, -а мы уже такъ затхали, ч'то возвратиться кь егерскому посту значило быть еще ближе кь ретраншаменту, а до батареи еще было далеко; отдаться въ нльнъ охоты не было, а равно даромъ и убиту быть; потому я р'ышиля, не смотря на крутизну рва, спуститься и рвомь добраться до егерскаго поста, что́, благодареніе Богу, удалось. Можно сқазать, у страха глаза велики: в'ь обыкновенное время конечно никто не осмълытся спуститься на лошади въ сей буераюъ. Долженъ я еще признаться въ моей храбрости: съ польской стороны, по правой сторонь Днбстра, заложена была сею же ночью батарея, которую я желалъ виджтьь; Турки, для воспрепятствованія работы, стрьляли ядрами; первое, которое я услышаль, заставило меня съ такою торопливостію нагнуться, чт0 об̆ шлифныя пряжки у меня лопнули.

Пробывъ при Хотинъ дня два, возвратился я въ главный корпусъ.

В0 время пребыванія моего при главномъ корпусъ, получено извъстіе, что шведскій король Густавъ III ${ }^{122}$ ) внезапно объявиль войну и вступиль въ россійскую Финляндію, а Ф.тоть его, подъ командою герцога Зюдерманландскаго ${ }^{123}$ ), атаковаль Балтійскій Порть и требоваль отъ коменданта сдачи; вомендантъ былъ майорь Кузминъ, старый инвалидъ, у котораго въ прежнюю войну была оторвана рука; онъ отвъчаль: «Я радь бы отворить ворота, но у меня одна рука, да и та занята шпагою». По ньсколько-дневной храброй оборонъ, герцогь принужденъ быль отойдти насупротив' русскаго Флота, вышедшаго изъ Кронштата подь

122) Густавъ III корошь шведскій, род. ${ }^{13} / 24$ января 1746 , царствовал'ь съ 1771, убитъ Анкерштремомъ \%/16 марта 1792 г. $M$. I.

123) Герцогъ Зюдерманландскій, братъ Густава III, бывшій въ посльдствіи королемъ шведскимъ $(1809-1818)$ подъ именемъ Карла ХІІІ; род. 1748 , ум. 1818 г. M. I. 
командою вице-адмирала Грейга $\left.{ }^{124}\right)$. Произошла у Ћрасной Горки морская баталія; всъ выстржыы въ Петербурге были слышны; дворъ готовился выъзжать ${ }^{125}$ ). Но Грейгъ одержаль славную побъду и взяль вице-адмиральскій корабль съ начальникомъ онаго гр. Вахмейстеромъ ${ }^{126}$ ). Вътеръ способствоваль пведскому Флоту укрыться въ своихъ гаваняхъ, но Грейгь быль опасно раненъ и вскоръ оть раны унеръ ${ }^{127}$ ).

Въ Финляндіи собрана наскоро армія, которая поручена была в'ь команду генераль-аншефу графу Валентину Платоновичу Пушщину ${ }^{128}$ ).

124) Самуиль Карловичъ Грейгъ, адмиралъ, род. 1736, перешель ивъ англійской службы въ русскую въ 1764 году, умеръ 15 октября 1788 г. $M . \Omega$.

125) Грейгъ сражался съ ІІведскимь Флотомь въ 1788 г. не у Красной Горки, а близь острова Хохланда. Въ 1790 г. адмираль Крузъ отразил' флоть герцога Зюдерманландскаго у острова Сескара и въ этомъ дъљь сражающіеся могли подходить къ Красной Горкъ. Бой продолжался оть зари до поздней ночи и канонада была слышна въ Петербургъ. Авторъ, гажется, смбшиваеть въ отношеніи мьстностей и времени әти цва сраженія. Впрочемь онь упоминаеть и о второмь ниже. $H$. $I$.

126) Пльнный Вахтмейстерь быль отправленъ въ Москву, гдъ присутствіе его вовбуждало самое нескромное любопытство на гуляньях и проч.; за ними бъгали толпами, особенно женщины, на что́ и была написана сатирическая пाъссня. $\boldsymbol{M}$. JI.

127) Туть авторъ ошибиется: Грейгъ умер'ъ не оть ранъ, а оть кратковременной, но тяжкой бользни, которой, какъ говорять, не мало способствовала горесть, причиненная ему еще въ іюль, посль' сраженія при Готландъ, взятіемь въ пльнь нашего норабля ІІведами. Горесть эту не могли утьшить ни дальньйшіе успьхи, ни благоволеніе императрицы, ножаловавпей Грейгу андреевскую ленту. $\boldsymbol{M}$. $\boldsymbol{I}$.

$\left.{ }^{128}\right)$ Графэ Валентинъ Платоновичь Мусинъ-Пушкинъ, фельдмаршаль, род. 6 декабря 1735, ум. 8 іюля 1804 г. Отецъ его, графъ Платонь Ивановичъ, сосланъ по дёлу Волынскаго, а сынъ, графь Василій Валентиновичь, оберь-шенкъ (род. 1775, ум, з̆ апрьля 1836) женился на дочери посльдняго графа Брюса (Яюова Александровича) ц 
Тамъ же получено извъсстіе отъ свъ̆тльйшаго князя, что посланъ быль флота капитанъ Сакень на дубль-плюбкь, для развъдыванія о непріятельскомъ флоть и содержанія брандвахты близь Кинбурнсгій косы. Онъ, усмотръвъ передовыя суда капитанъ-паши, идущія на всъхт парусахъ, почель за благоразуміе идти на Глубокую Пристань, для извыщенія принца Нассау-Зигена о появленіи непріятеля, или присоединиться къ русской эскадръ, стоявшей выше устья ръъки Буга предъ Станиславовою косою. Турки устремились за дубль-шлюбкою. Сакенъ, чувствуя несоразмъ̌рность силь, поспъшаль удалиться, но четыре турецкія галеры, очень легкія на ходу, настигали его и кричали, чтобъ онъ сдался. Сагенъ, войдя въ устье Буга, высадиль всыхъ бывшихъ людей и чтобы не дать завладъъть судномъ Туркамъ, самъ съ зажженнымъ фителеиъ спустился вт грюйтъ-камеру. Вскорж дубль-Ішлюбка была окружена пресльвдовавшими ее галерами; экипажъ ихъ, видя русское судно оставленное, смъло присталь къ борту и толпы взошли на палубу, какъ вдругъ съ трескомъ дубль-шлюбка поднялась на воздухъ и вмъстё съ нею турецкія галеры со всъми на нихъ бывшиими людьми. Такимъ геройским' подвигомъ капитанъ Сакенъ кончиль жизнь свою, увъ̌ковъччиъъ ее въъчною славою.

0чаковская осада продолжалась медленно, которую называль фельдмаршаль осадою Трои; однағожь были успьхи на водахъ, какъ то: напа флотилія одержала побъду надъ

въ 1796 году къ фамиліи его присоединена фамилія Брюса, съ нимъ угасшая. Въ царствованіе Алегсандра I, графъ Мусинъ-ПушкинъБрюсъ былъ великимъ мастеромъ великой масонской ложи Астрея, существовавшей въ Петербургй и бывшей центральною для 18 соединенныхъ ложъ, изъ которыхт семь было въ Петербургъ, двъ въ Ревелъ, а остальныя: въ Кронштадтъ, въ Өеодосіи, въ Житомирћ, Москвъ, Митавъ̌, Симбирскъ, Полтавъ, Кіевъ и Мобёжъ (во Франціи) при главной квартиръ нашихъ войскъ, остававшихся во Франціи до 1818 года. $M$. ЛI. 
Флотиліею турецкою, равно и большой нашьь флоть заставилъ турецкій оставить Очаковъ.

Вь теченіи очаковской осады, Александрь Васильевичь Суворовъь въь одинъ день при вылазгъ̌ завязалъ бо:тьшое дъъл0, посылая безпрестанно по нъ̌скольку батальонов'ь занять сады, прилежавшіе къь грйпости, такь что весь львый Фланг'ь вступиль в'ь сраженіе, и наши войска много претерпёвали, отъ усилившихся подкржпленій Турокъ въ выгодной для нихъ позиціи. Кажетсп, намъреніе его было, видя медленную осаду, заставить свъттльйшаго князя симъ средствощъ ржшиться на штурмъ или самому съ своимъ корпусомъ на плечахъ Турокь ворваться въ крв̈пость; и ежели бы князь Репнинъ ${ }^{129}$ ) не выручиль съ своимь корпусомъ, то наши бы войска претерпъли значительный уронъ. Александръ Васильевичъ раненъ быль въ руку легко. Свъ̌тль̆ы̆шій ннязь послаль его спросить дежурнаго генерала: «Какъ онъ оспьллися безъ повельнія завязать столь важное дъ̌ло?» Суворовъ отвъччальь: «На гамушкъ сижу и на Очаковъ гляжу⿰ .

Фельдмаршаль' получиль донесеніе от'ь графа Салтыгова, что Хотинъ Турки сдають на капитуляцію, но требовали сроку на три дня; Фельдмаршајъ к'ъ тому времени приказаль, чтобы на батареяхъ были пушки заряжены стрбылть викторію о сдачъ Хотина, когда курьеръ прівдеть; но онъ прібхаль сь тьйъ, что отстрочено еще Туркамь на три дня, и готомъ еще на три дня ${ }^{130}$ ); фельдмаршаль быль очень

129) Князь Николай Васильевичъ (посльдній князь Репнинъ), фельљмаршалъ, род. 11 марта 1734 г., умеръ 12 мая $1801 \mathrm{r}$. Онъ былъ однимъ из' главнъйшихъ мартинпстов'ъ. Новиковъ, Лопухинъ и другіе были его искренними друзьями. $\boldsymbol{M}$. JI.

${ }^{130}$ ) Сказывали, что медленной осадъ Хотина и еще болъе деватидневной отсрочгъъ была причиною жена Каменец'ъ-подольскаго польскаго комедданта Витта (которая посльь была за графомъ Потоцкимъ), въ которую грабъ Салтыковъ быль влюбленъ, и которая часто прібзжала 
недоволенъ и, не ожидая уже въятія Хотина, выступиль съ главнымъ корпусомъ впередъ. Веъ мы, молодые служивые, обрадовались, что наконець увидииь непріятеля, и ревностно хотьели съ нищь сразиться; но дошедъ въ ньсколько маршей, сстановились до окончанія кампаніи при урочищъ Цицорахъ, на лъвой сторонт⿱宀 Прута, въ 20 верстахт өтъ Яссь.

Ћорпусъ генерала Әльмта заняль Яссы и поступиль, по отпуске его, въ ґомандованіе генераль-поручика князя Бориса Григорьевича Шаховскаго ${ }^{131}$ ); черезъ день резервный

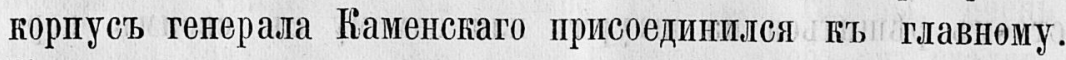
На маршь получено донесеніе графа Салтықова 0 занятіи Хотина и сдачґ онаго Цесарцамь. Графу Салтыкову поручено занять Кишеневъ и наблюдать Бенцеры.

Непріятельскій лагерь открытъ быль, въ сорона верстахъ на львой сторонъ Прута, противь Рябой Могилы, въ большиихъ силахъ.

«а малоимжніем' легкихь войскь, фельдмаршаль приказаль отставному полковнику Сиверсу, бывшему волонтеромъ, набрать три тысячи Арнаутовъ ${ }^{132}$ ); епу поручены отъ трехъ корпусовъ Донскаго войска казачьи полки и повелььно быть въ десяти верстахъ отъ арміи, имьть свой станъ, охранять оную и посылать партіи для развъдыванія. Ръдко очень

въ лагерь; она была Гречанка, сестра ел оыла замужемь за Хотинскимъ пашею, почему графъ, по просьбъ ея, посылываль парламентера съ письмами отъ г-жи Витть къ сестрॐ, а отъ той получала она на оныя отвъты.

131) Князь Борисъ Григорьевичь Шаховской, генералъ-лейтенантъ, умеръ 1813 года. $M$. II.

132) Арнаутами звались туть Молдаване или Волохи, добровольно вступавшіе въ службу на своемъ конй и вооруженіи, ва что́ получали по червонцу въ мъсяць жалованья, провьянть и фураж'ь; они хуцо

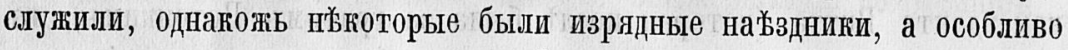
славился ихъ начальникъ майорь Іордаки. 
казаки встр'ъчались сь Турками, а еще ненъе было небольпихъ схватокъ; Турки такь боялись Русскихъ, а еще болье имени Румянцова, что каюъ скоро завидятъ казака, то бывал0 и бжгутъ; однакожь во все то время нахватали человъ̆ъ до пятидесяти пльнныхъ.

Армія имьља всегда съ собою провіянтъ, люди на себъ в’ ранцахъ на четыре дня, въ фурахъ полговыхъ на шесть, да въ каждый полкъ даны были возы на волахъ, и на оныхъ было провіянта на 22 „ня. Транспорты сь провіянтомь еженедъъљьо приходили изъ Польши; заготовленіе онаго поручено было генераль-майору Шамшеву и генераль провіянтмейстеру, бригадиру Новицкому. Для прикрытія магазиновъ въ Польшъ, подъ командою сказаннаго Шамшева, оставался Днъпровскій мушкетерскій полкъ, отъ ньъоторыхъ мушке-

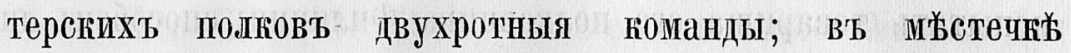
Сорокъ, Молдавскаго княжества, построенъ быль ретраншаментъ, въ қоторый свозили покупаемый въ Польпь провіянтъ и фуражь.

Въ Польшъ сдылалась революція, и 3 мая сеймъ утвердиль новую конституцію; Поляки оказывали непріязненное къ намъ расположеніе; посоль нашъ гр. ІІтагельбергъ ${ }^{{ }^{133}}$ ) лишился прежняго своего вліянія, а довъренность Поляковъ получиль прусскій министръ Јуккезини ${ }^{134}$ ).

Цесарскія войска непрестанно, хотя и не было генеральной баталіи, но во многихъ сраженіяхъ Турками были поражаемы. Ииператорь неоднократно просиль фельдмаршала сдйлать движеніе для диверсіи въ пользу Австрійцевъ, но графъ и сь мыста не тронулся, подъ видомъ, чтобы при

133) Графь 0тго Магнуеь Стакельбергъ, роц. 7 певраля 1736 года, умерь 1799. M. II.

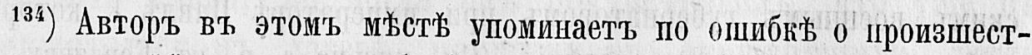
віяхъ повднъйшихъ; эти событія относятся къ 1791 году, въ которомъ состоялась конституція 3 мая. Съ сльдующей за тыммъ фразы начинается опять связный разсказъ. $M$. J. 
его движеніи не открыть мьста, чрезъ которое Турки могли подать сегурсъ 0чагову ${ }^{133}$ ). Неодногратно для сего прівзжали въ лагерь австрійскіе генералы: Іордышъ, Сплени и Карачай; а сверхъ того, для наблюденія нашихъ дъйствій, при нашей арміи быль полковникъ Гербертъ; подъ исходъ уже кампаніи, изъ-подъ 0чаюова пріъзжаль въ Яссы принць де-линь, опкуда часто пріжзживаль для сего же въ лагерь. Несмотря однакожь на его красноръчивыя убъюденія, Фельдмаршаль и шагу не дъ̌ы

Главнокомандую́щій быль очень недоволень генераль-гвартермистромъ Бердяевымъ, готорый дъйствительно не имъљь особливыхъ дарованій, ни прнродныхь, ни пріобрғттенныхъ свъдъніями. Кь генералъ-квартермистру лейтенанту Медеру онъ по особливымъ причинамъ не благоволиль и хотьљљ испытать товарища его полковника Филиппи: способенъ ли онъ, еслибы нужда потребовалась, на какое важное предпріятіе. Фельдмаршаль даль ему повельніе сь сотнею казаковъ ьхать по правую сторону Прута и рекогносцировать: ножно ли, поставя батарею на Рябой Могиль, анфилировать непріятельскій лагерь? Пруп'ь въ т0 время былъ такъ мелокъ, что было только лошади по кольно; фельдмаршаль, давъ ену приказъ, не объявиль, что полговнику Сиверсу дано уже повельніе,一что Филиппи поъдеть регогносцировать; а потому чтобы Сиверсъ заранъе со всъии своими легвими войсками отправился впередъ и его бы прикрываль, и ежели не только опасно будеть Филиппи, но даже можно опасаться потери одного человъьа его команды, то чтобы самъ воз-

133) 0 причинах'ь әтого бездъйствія Румянцова, въ отношеніи Австрійцевъ, авторъ уже говориль въ I главъ своихъ Записокъ. Квартермистрь Бердяевъ, о коень говорится ниже, быль екатеринославскимъ военнымъ губернаторомъ при императорь Павль' I, который имъљљ къ нему большое довъріе. (Сп. письма е. в. къ Бердяеву, въ Чтеніяхб Императ. Оби. Исторіи и Ареен. Росс. 1858 г., кн. І. отд. วँ, стр. 10ذ). M. $I$. 
вратился и далъ бы Филиппи запечатанное повельнніе, въ которомъ ему приказано было возвратиться безъ исполненія порученнаго. Филиппи, получивъ приказаніе оть Фельдмаршала, думалъ, что посылается на неизбъжную смерть. 0тъжхавъ верстъ десять, спросиль онъ Молдаванъ: есть ли Турки на той сторонъ? И какъ они ему сказали, что много, то онъ и отправился назадъ. Вошедъ къ фельдмаршалу в' ставку, когда уже было большое собраніе, и какъ на тоть разъ хотинскій гарнизонъ не в'ь дальнещъ разстояніи отъ лагеря проходиль подъ прикрытіем'ь австрійскихь войскъ, то командующій онымъ конвоемъ генералъ и многіе австрійскіе штабъ-0фицеры тутъ были. Фельдмаршалъ, какъ скоро увидъль вошедшаго Филипши, подошель к’ь нему и спросиль на ух0: Sind Sie da gewesen? Были ли вы тамъ?Nein, Ihre Erlaucht. Нъть, ваше сіятельств0.-Warum? Для чего?-Ich fürchtete. Я побоялся.-Тогда вдругъь вскричаль фельдмаршаль громко: «Счастливъ ты, что сказаль не порусски, а ихъ языномъ (показавъ на Австрійцевъ), а т0 бы тотчась вельыль тебя разстрьлять.)-И посль сего не только никогда его не употребляљ, но даже съ нимъ никогда уже не говорилть

Тогда фельдмаршаль вздумал'ь испытать дививіоннаго квартермистра Јена. Когда хотинскій гарнизонъ вышелъ въ турецкій лагерь, то сераскиръ присылалъ парламентера благодарить за исполненіе въ точности капитуляціи. Фельдмаршаль воспользовался сим'ь, послаль Јена съ пустымъ комплиментомъ, н0, отправляя его, сказаль ему: “Непременно привези ты мнъ планъ позиціи непріятельскаго лагеря». Ленъ вотъ каґъ исполнил'ъ сіе порученіе: каґъ скоро пріъхаль къ аванпостамъ съ трубачемъ, то далъ себъ по обыкновенію завявать глаза, но когда онъ почувствовал'ь, что уже в' непріятельскошъ лагеръ, по шуму его окружавшихъ, тогда вдругъ сдернулъ повязгу; нъвоторые Турки было оросились на него, но онъ, выхвативъ пистолетъ, угрожаль выстрь- 
ломъ. Онъ приведень быль въ палатку, обгороженную тростникомъ, но уже успйлъ увидъ̌ть все положеніе турещкаго лагеря. При воввращеніи своенъ, натертиль планъ и представиль его фельдмаршалу, готорый спросилъ: «Какъ, батюшка, вы это сдъълали?) И когда онт ему отв'ъчалт, то графъ его обняль и сказаль: будель друзьями, господинъ Ленъ.

Скажу вамъ, что впаль оыло я въ гнусный порокъ, но, благодареніе Богу, добрый мой пріятель от"ь того меня

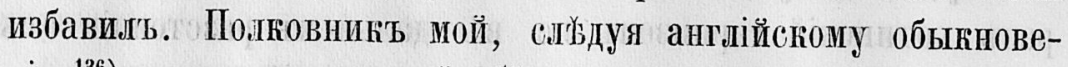
нію ${ }^{136}$ ), подпивалъ; посльь объдда ставили чашу пунша. Пріятели его, а мои товарищи стали на мой счеть подшучивать, что похожъ ли я на гренадерскаго оФицера: водки и пунша не пью и трубюи не курю. желая быть въ числь короткихъ пріялелей своего полковника и быть настоящимъ гренадерскимъ офицерош'ь, сперва пильь я въ угожденіе, потомъ это вошло въ привычку и наконець не только у полковника, но уже я искалъ въ другихъ мйстахъ, гдъ бы подпить; словомъ сказать, ни одного дня не проходило, чтобъ я не быль пьянъ. Роштейнъ произведенъ быль недавно сенундъмайоромъ, онъ не успъль еще завестись своею палаткой и жилъ у меня. Въ одинъ день посль объда, соснувъ, я

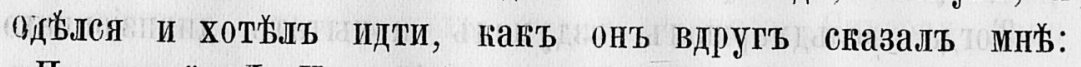
«Послушай, Ј. Н., ва благосклонность твоего ко мнъ зятя, бывшаго нашего командира, и по дружбб моей къ тебъъ, я долженъ сказать, что уже наконець я выхожу изъ терпьннія,

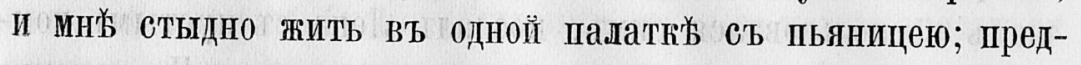
ставь, тто вотъ уже оюоло мьсяца, какь ты всякій день пьян'ь и теперь, я вижу, спъшишь искать пуншъ; ежели не исправишься, я тотчасъ съ тобой разстанусь». Чувствительна инё была такая укоризна; снатала я было на него разсердился, но накъ скоро одумался, то дъйствительно увидъ̆лъ, что страсть сія во мнґ сильно укоренилась. Я

136) Княвь Дашюовъь былъ воспитанъ въ Англіи. M. $\boldsymbol{\Perp}$. 
даль себь слово больве не пить, и могу сказать, что съ тььхъ поръ во всю мою жизнь быль трезвой и воздержной жизни; счастливая минута, въ которую другь мой свопмъ словомъ излььчиль меня!

Въ началь ноября сдъ̌злались большіе морозы, выпаль снь̌з, и стала зима, какой въ Молдавіи никто не помнилъ; ръки замервли и даже Јимань подъ Очаковымь.

1丂-го числа полковникь Сиверсъ цонесь, что Турки лагерь свой оставили; генераль Каменскій получиль повел'нніе пресль'довать непріятеля, а по другой сторонь Прута генералъ-поручику князіо ІІаховскому приказано идти впередь до Васлуи и начальствовать передовымъ корпусомь.

Войска 22 числа вошли в'ь зпмовын квартиры; въ Щыщо-

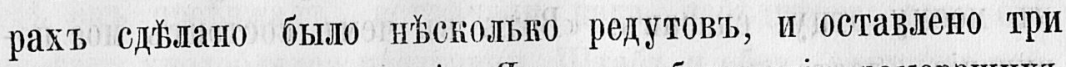
батальона для прикрытія Яссь и сбереженія замерзшихъ понтонныхъ постовъ. Корпусь кишеневскій порученъ быль генералу Ћаменскому, на мъсто графа Салтыкова, который отпросился въ Петербургъ. Главная квартира заняла Яссы.

При выходь̌ изъ лагеря, накануне того дня, говориль я полковнику, что инъ хочется побывать ґъ батюшюь; онъ мнжь' сказаль, что о томь скажеть фельдмаршалу, который, какъ скоро о томь услышаль, сь гнбвошъ сказаль: «Мы еше не вошли въ зимовыя квартиры, а молодые люди уже скучають службой». Хотя всь знали, что уже и приказъ написанъ, только еще не быль объявленъ, но чрезъ ньсколько часовъ оный и отданъ быль при пароль.

Штабы већхъ полковъ, составлявшихъ главный корпусъ, остались въ Яссахъ, а полки были расположены въ окружностяхъ. Я уже лишился было надежды быть въ отпуску, а проситься боялся и подумать.

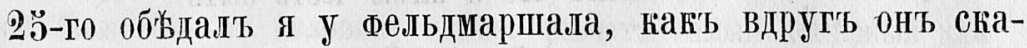
заль мнт: “Какъ, господинъ майорь, я слышаль, что вы хотите въ отпускь?»- М ему отвьчаль: “Если ваше сіятель-

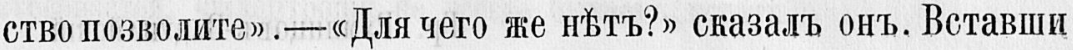


изъ-за стола и подошедъ ко мнб, онъ спросиль: «Сюоро ли вы хотите вхать?»- - Какъ вашему сіятельству угодно».“Однакожь, еслибьь от” васъ зависил0?»- (Я бы уьхаль сего же дня».- «Вы очень скоры, однакожь я васъ пропу остаться только до шести часовь утра завтрашняго дня, а притомъ я вась буду просить взять на себя нбкоторыя порученія, и завтра вь шесть тасов' прошу ко мнжљ). Я думал'ь, что

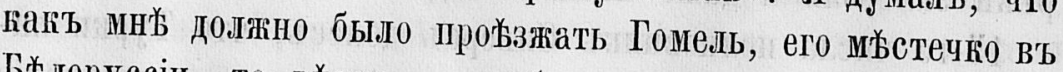
Бьшгорссіи, то вьрно чт0-нибудь прикажеть къ его тамъ управляющему. Не успъль' я въ шесть часовъ поутру явиться, какъ уже дежурный генераль сказаль, что фельдмаршаль меня ожидаеть. Я вошель въ кабинеть. Грать даль мнеь паспорть на двадцать девять дней, подорожную и письмо къ моему отщу, сказавъ: “Воть вь чемь состоить мое порученіе, доставьте удовольствіе вашему батюшкъ видетть добраго сынам ${ }^{137}$ ).

Лестное сіе письмо я почитаю лучшимь себъ атестатомъ В’b мою службу. Съ какою деликатностію сей великій чело-

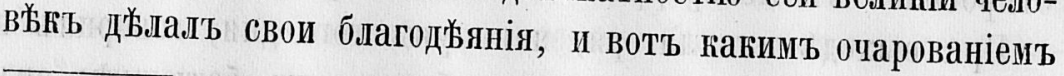

137) Воть содержаніе сего письма:

\section{«Милостивый Государь мой Николай Богдановичъ!}

Податель сего будеть вамъ лучшимъ свидъ̌ттелемъ моего къ вамъ усерція, но я не могу однакожь отказать себж того удовольствія, чтобы не представить его тоже съ моей стороны, свидйтельствовать 0 его лучшемь поведеніи и прилежности къ службю и вамь не пожелать всяғаго самомысленнъйшаго добра, и что я въ особливое себъ удовольствіе вмънняо всякій случай, который мнжъ подаетъ способы вамъ и вашему достойному сыну мои услуги оказать. И съ сими чувствами и искреннъйшимъ почтеніещь что я имњю честь быть

Вашего ІІревосходительства всепогорнъйшій и всегдашнъййій слуга

Гр. Румянцовъ-Задунайскій. 
привявываль кь себъ! Хотя чины и кресты во время его командованія трудно доставались, но за то они были имь раздаваемы справедливо и за настоящее дъљло, кто чего заслуживалъ; за то всякая награда принималась съ величайшимъ уваженіемъ.

Можете себъ представить, съ каґимь удовольствіемъ отець мой меня увидъль съ графскою рекомендаціею. Уже въ бытность мою въ Могилевъ, узналь я 0 взятіи штурмомъ 0чакова шгестаго декабря ${ }^{138}$ ).

Свътльйшій княвь награжденъ орденомъ Св. Георгія 1-го класса; но его рекомендаціи всъ щедро награждены орденами и крестами; по нъкоторомъ времени отправился онъ въ С.-Петербургъ, гдъ его съ тріумфомъ встрьтили, и по пути, гдъ онъ прожзжалъ, встръчали какъ побъдителя; весь его проъздъ уподоблялся празднигу. ІІтабъ и оберь-офицеры всь получили золотые кресты на георгіевской ленть́ съ надписью: «За службу и храбрость», а на другой сторонъ: “Очаковь взять 6 декабря 1788 года». Нижничь чинамъ даны серебряныя медали.

1789. Въ 1789 году явился я изъ отпуска къ фельдмаршалу, нбесколько дней просрочивъ, и боялся его выговора; но вмьсто того, увидя меня, онъ сказалъ: “Какъ, вы уже возвратились?»- - $Я$ и такъ, ваше сіятельство, про-

138 ) Взятіе 0чакова стоило очень дорого; потеря людей чрезвычайно значительна, не убитыми, но отъ продолжительной кампаніи; зима, наставшая въ томъ краю ранъе и холоднъ̌е обыкновеннаго, изнурила людей до того, что едва четвертая часть осталась оть многочисленной арніи, а гавалерія потеряла всъхъ почти лошадей. Свътль̆йшій князь, жалья людей, ръшшлся на штурмъ по необходимости поздно; еслибы штурмъ данъ былъ тотчасъ по отбытіи турецкаго Флота, то потеря была бы въ половину менъе; разчеть самый невърный для сбереженія людей-поздняя гампанія, а особливо въ мъ̌стахъ, гдъ продовольствіе такъ затруднительно, и есть лишеніе всъхъ нужныхъ потребностей. Филантропія не всегда бываетъ кстати. 
срочилъ; причиною тому больпія метели», отвъчаль я. И дъйствительно, подъъзжая къ Могилеву, подводчикъ мой потеряль дорогу, всю ночь проплуталь и почти къ свьту, заъхавъ въ сторону, наткнулся на одну деревню, гдь дождался свъту; въ ту крутую зиму многіе оть вьюгь пострадали. «Напрасно вы спґшнил, дъ̌ла теперь нжть, вы бы могли еще пробыть столько же у вашего батюшки; однакожь это не худо: впередт будете имъть кредитъ».

Во время моего отсутствія, генералу Каменскому повельно было выгнать Татаръ изъ занимаемыхъ ими квартирь, селеній Гангурь и Салуцъ, къ сторонъ Бендеръ. Каменскій, напавъ на нихъ нечаннно, почти всъхъ ихъ истребилъ; въ томъ числьь быль убить сынъ хана, командовавшаго оными; малое число изь нихт спаслось. Этимь вимовыя наши квартиры стали безопасны и во всю зиму не были непріятелями обезпогоиваемы; почему три батальона, подъ командою полковника Владычина, оставленные при Цыцорахъ въ землянкахъ, для прикрытія укрь̆ленія, отпущены, а на мъсто ихъ для караула понтонныхъ мостовъ оставлено двъ роты.

Князь Г. С. Волконскій, на другой же день моего прибытія, командироваль меня къ онымъ двумъ ротамъ. Фельдмаршаль того же дня спросиљь нашего полка премьерь-майора Клугина: “гдь же вашъ пріжзжій майорь Әнгельгардть?»а какъ тотъ отвиччаль, что командированъ въ Цыцоры для караула мостовь князешь Волконскимь, туть бывшимь, фельдмаршаль съ гнъвомъ сказаль ему: “Для чего штабъофицера нарядили въ карауль? Тотчась пошлите ордерь господину майору, чтобы сдаль онт команду старшему по сео̄ъ капитану, и завтра явился бы ко мнъ. Господинъ генераль, примолвиль онъ, молодыхъ, хорошихь офицеровъ надобно поощрять, а не унижать»:' Получа сіе повельнніе, я очень обрадовался, тьмь болье когда узналь о пріятномь отзыв' обо мнг фельдмаршала. 
По прибытіи въ Яссы, занялся я, какъ прежде уже себъ шредположиль. Досталь я внигу Le parfait ingénieur Français, гдъ всъ до того времени извъстныя системы всъхт авторовъ 0 врбиостяхъ подробно описаны, и могу сказать, что прилежаніеиъ своипъ всъ три манера укржшленій Вобана и регулярныя кр'ппсти его и Когорна твердо самь собою выучиль, равно гағъ атагу, такь и защиту; тағже къ оному присовокупилъ: De l'attaque el de la défense des places, par Blondel. Изъ библіотеки князя Дашкова много читаль тактическихъ книгъ; словомъ, зимовыя квартиры провель я съ пользою, а въ сльдующій годъ прошель я и курсъ артиллеріи, готовясь служить съ замъччаніемъ и быть годнымъ кь употребленію, когда какой случай предстанетъ.

0бразъ жизни фельдшаршала въ Яссахъ быль тавовъ: онъ вставалъ всегда въ пять часовъ; в'ь шесть приходиль къ нему съ рапортонъ дежурный генераль, потомь секретари его разныхъ экспедицій по очереди подносили ды̆ла, поторыя онъ приказываль къ тому дню приготовить; въ десять въ кабинетъ были допускаемы генералы и нъкоторые полковники; въ одиннадцать выходиль онъ въ пріенную комнату и изъ бывшихъ тутъ съ каждымъ почти говоријъ. Наконецъ отворялись двери, и допускаемы были къ нему люди всякаго званія съ просьбами: солдаты, Молдаване, Жиды, словомъ кто только имъљљ до него дыны0; словесныя просьбы выслушиваль онъ съ терпьніемь и тогда же дълаль удовлетвореніе, отсылая ихъ пуда сльдуетъ, или чрезъ своихъ адъютантовъ или ординарцевъ; писанныя же просьбы принималь и клалъ въ карманъ. 0бъдалъ въ первомъ часу въ половинь; столь его, такъ же какъ и въ лагерь, быль на сорокъ приборовъ; посль об̆ъда чрезъ полчаса откланивался и уходиль въ кабинеть; тамъ ньсколько отдыхаль, а проснувшись разсматриваль просьбы, на всякой своею рукой надписываль резолюцію и къ которому числу долженъ ее секретарь исполнить, записывая у себя въ особливую 
тетрадь и въ сльдующее утро справлялся ст нею: какія дыла и который секретарь должень быль ему доложить. Въ шесть часовъ вечера приходили секретари, и гаждому изъ нихъ по экспедиціи онъ отдаваль тү্் просьбы; ежели какая поступала просьба недъльная, то онъ наддираль у оной уголокъ: то было внакомъ, чтобы просителю отказать. Потомъ выходиль въ пріемную, гдъ собирались генералы и штабъ-оФицеры и дъълали партіи, а въ девять часовъ онъ откланивался, и всъ̌ разъъ̌зжались. Во все время той зимы въ Яссахъ было тихо; у ныкоторыхъ боярь бывали балы, какъ-то у князя Кантакузена, у Стурдзы и нъкоторыхъ другихъ. На оныхъ балахъ танцовали Молдаване свой танецъ, называемый жоко: становились вт кружокъ мущины и женщины, держась рука за руку, и, важно подвигая ноги то въ сторону, то впередъ, обходили кругомъ по ихъ музык`љ, составляющейся изъ Цыганъ (инструменты: кобза, родъ гитары, свиржль и двъ скрипки), съ приптваніепь гнусящихъ сихъ самыхъ музыкантовъ. Сіи же танцы и въ простомъ народъ употребляются. На сихъ балахъ въ другихъ комнатахъ игрывали въ карты, и многіе бояре страстно играли болышею частію въ рокамболь и азартныя игры. Между ть্ьмъ разносили варенье, фрукты, шербетъ, и желающіе курили трубки.

Въ март卣 князь ПІаховской донесъ, что онъ атакованъ превосходными силами, и требоваль скораго подкрњпленія. На зиму веъ почти полковники отправились въ отпускъ, одни птабъ-офицеры командовали полками. Фельдмаршалъ приказаль нарядить два батальона Сибирскаго и два батальона Малороссійскаго полковъ съ ихъ полковыми орудіями и отъ каждаго полка штабъ-офицера; старшему изь нихъ приказаль поручить всъ четыре батальйона. Старшимь случилось быть мнъ, и на другой день должень я быль явиться къ фельдмаршалу для полученія приказанія и тотчасъ выступить. Я быль въ восхищеніи, всю ночь занять былъ 
распоряженіями, быль у генералъ-квартермистра для полутенія наршрута, скөпироваль карту окружности Васлуп. Мечталась в'ь монхъ пыслюх слава, которую пріобрбту я моими дарованіями и храбростію, но мечта сія на другой же день рано исчезла.

Һнязь Паховской донесъ, что вмъ九сто большихь непріятельскихъ силь, которыхъ онъ самъ не видалъ, тольюо передовые посты его были атағованы сильною партіею, ко-

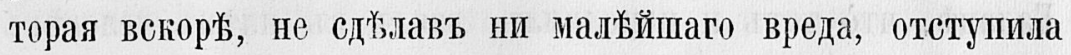
къ свопмъ квартирамъ къ Галацу. При тощъ схваченные Турки сказывали, что тамъ дызлаютъ нъсколько отдыльныхь укрњпленій, полагать должно редутовт.

Въ исходж же марта, главнокомандующій сдъвлаль производства на вакансіи; мнбе досталось преміеръ-майоромъ въ Дн'ъпровскій полкт, пребывавшій для прикрытія магазинов' въ Польшъ.

Фельдмаршальь, вскор посль взятія 0чакова, просилъ у императрицы, по преклоннымъ л'ьтамъ и болхзинят, увольненія оть командованія арміею, на что государыня соизволила указать при милостивошъ рескриптъ. Посль того объ арміи соединштись подъ воманду свйтльйшаго князя Потемғина, но до прівзда его назначено принять оную генералъ-аншефу князю Николаго Васильевичу Репнину; авангардный корпусъ-генералъ-аншефу Александру Васильевичу Суворову. Фельдмарпаль не хотъьль дожидаться князя Репнина, который тогда еще быль в' Россіи, и до прибытія его сдаль армію генералу Каменскому.

Суворовъ скоро прибыль и явился къъ фельдиаршалу в'ь курткж и каске, когда быль тамь и Каменскій, который всегда былъ по недугу своему в'ъ длинномъ мундирномъ сюртукъ, бълою портупеей подвязанномъ. Суворовт до выхода еще фельдмарпала изъ кабинета сказаль Каменскому: «Признаться, мы сь тобой велигіе оригиналы: оба мы у Фельдмаршала, котораго чтимь душею, только ты очень 
долго, а я очень коротком. Не замедлиль прибыть и князь Николай Васильевичъ Репнинъ и вступиль въ командованіе арміею. Тогда фельдмаршалъ переселился на рьъчк Жижу, въ деревню одного молдаванскаго боярина, въ десяти. верстахъ отъ Яссъ, гдъ и пробылъ почти до заключенія мира.

Въ апрьљ施 князь Репнинъ приказалъ генералъ-поручику Дерфельдену атаковать непріятеля въ укрљпленіяхъ его при

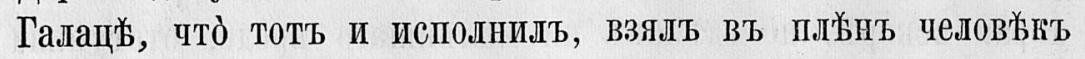
шестьсоть и двадцать пушегъ; прочія непріятельскія войска прогнаны за Серетъ юъ Браитову, а самъ Дерфельденъ возвратился въ Берлатъ, гдъ Суворовъ учредиль авангардный свой постъ.

Прибылъ я въ полюъ Дны̆повскій, расположенный въ Ямполь. Полковникъ сего полка Гавріплъ Нихайловичъ Рахмановъ былъ мнг очень радъ, пбо полкъ быль очень разстроенъ и снабженъ оФицерами новыми и неопытными; нижнихъ чиновъ почти не было, и всъ солдаты были изъ рекрутъ. И такъ, занялся я по своену званію новою своею должностію. По тогдашней службъ на преміеръ-майоръ почти, такъ сказать, лежаль весь поль: онъ настоящій быль хозяинъ; полковникъ занииался пріятнымъ начальствомъ, а все трудное и непріятное по службъ было участью премьеръ-майора; за то скоро могъ исправный найоръ сдълать свою репутацію и быть на замьтаніи у главнаго начальства.

Во время пребыванія полка въ Ямполь, генераль Каменскій, ‘хавшій въ отпускъ, пробыль вт Сорокъ недъ̆ли съ двъь; а какъ разстояніе отъ Ямполя по львой сторонъ Днъьстра не болье трехъ версть, то все то время мы пробыли съ нимъ вмьисть. Какъ скоро не касалось Московскаго полка, въ которомъ онъ быль шееъ, и гдъ офицерамъ по чрезвычайной его строгости почти служить было невовможно, какъ корпусный командиръ былъ онъ любимъ, а не по 


\section{$-99-$}

службъ былъ очень любезенъ. Онъ ожидаль скотъ и табуновъ своихъ, отогнанныхъ имъ во время экспедиціи на Гангуру и Салнакуцъ.

Нагонецъ Поляки настояли, чтобы наши войска выведены были изъ Польши, а сами сфюрмировали свои войска и обучали на прусскій нанеръ, почему полкъ Днъировскій получиль повел'ьніе идти въ Кишеневскій корпусъ, подъ ю0манду генерала Кречетникова. Главный корпусъ бывшей Украинской арміи быль въ Гинчештяхъ; передовой подъ непосредственнымъ начальствощъ генерала Суворова въ Берлат为.

Въ іюнъ Суворовъ, соединясь съ принцеиъ Кобургскимъ, разбиль непріятеля при Фокшанахъ и прислалъ релящію князю Н. В. Репнину, сльдующаго содержанія: “Ръ̌чка Путна оть дождей широка. Турокь тысячь пять-шесть спорили, мы ее перешли, при Фокшанахъ разбили непріятеля; на возвратномъ пути въ монастыръ засьли пятьдесять Турокъ съ байрактаромъ; я ими учтивствоваль принцу Кобургскому, который послаль команду съ пушками, и они сдались».

Всгорљ посл䒓 того полюъ нашъ былъ гомандированъ для обезпеченія переправы на Днъстръ идущену бывшей Екатериноставской арміи передовому корпусу, подь командою генералъ-поручика Павла Сергъевича Потемкина ${ }^{139}$ ), состоящему изь четырехь батальоновъ Бугскаго егерскаго корпуса, котораго шефомь быль незабвенный Михаиль Ларіоновичъ Кутузовъ $\left.{ }^{140}\right)$, и изъ четырехъ батальоновъ Екатеринославскаго егерскаго корпуса, котораго быль шефъ

139) Графъ Павель Сергъевичъ Потемгинъ, генералъ-аншефъ, ум.

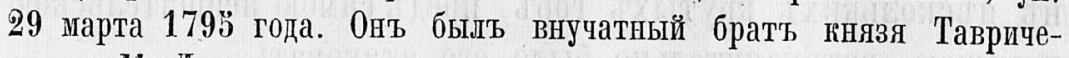
скаго. M. JI.

140) Свъ̌тльйшій князь Михаиль Ларіоновичъ Кутузовъ-Смоленскій

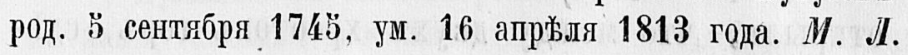




\section{$-100-$}

зять мой Сергей Козьмичъ Вязмитиновъ, а также изт двухъ гусарскихъ полюовъ. За онымъ и вся Екатеринославская армія сльддовала (которая потонъ заняла повицію подъ Фоншанами, до блокады Бендеръ). Какъ скоро переправился тотъ авангардный корпусъ, полкъ наптъ возвратился въ лагерь подъ Кишиневъ.

Свъьтлљйшій князь прибыль къ арміи; осмотржвъ нашт корпусъ, вздилъ для осмотра главнаго горпуса бывшей Украинской арміи, при Гинчештяхъ; потонъ отправился уже къ собравшейся при Фокшанахъ арміи.

По полученнымъ извъстіямъ, что визирь съ большою арміею идетъ на австрійскій корпусъ принца Кобургскаго, расположенный отъ Берлата болье ста версть, Суворову предписано соединиться съ принцем'ь и разбить визиря; а князю Репнину, присоединивъ къ себ※ корпусъ генерала Кречетникова, разбить Гассанъ-Пашу, расположеннаго въ Таба́ьъ. Гассанъ-Паша въ прошлую кампанію былъ капитанъ-пашею и въ нагазаніе, что не способствоваль защитъ 0чақова, былъ разжалованъ, сдъљанъ комендантомъ Измаила, и приказано было ему оть султана сь сильнымь корпусомъ занять Табакъ и препятствовать нашей арміи подать помощь Австрійцамъ.

Соединенные наши два корпуса составляли болъе двадцати тысячъ регулярнаго войска и три тысячи казаковъ.

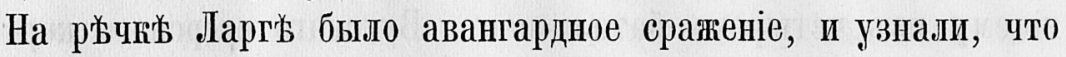
Гассанъ-Паша занимаеть крьпную позицію в’ь укрьплен-

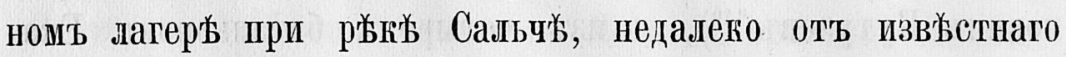
урочища Кагуль, славнаго по побъдъ, одержанной Фельдмаршаломь графомъ Петрощь Александровичемъ Румянцовымъ-Задунайскимъ въ прошлую войну; и что, по причинъъ ньсколькихъ крутыхъ горъ, предъ самою непріятельскою позиціею, затруднительно было его атаковать.

Генералъ-квартермистръ-лейтенантъь Медеръ рекогносцировалъ и открылъ, что между двухъ хребтовъ горъ, сдъ̌- 


\section{$-101-$}

лавъ двадцать верстъ лишнихъ, скрытно можно было обойдти сіи горы и придти во Флангъ, гдъ̌ непріятель не инъ̆ль никакого укрьнленія и никағъ насъ съ той стороны не ожидалъ. Почему съ вечера выступили боковымь маршемъ лощиною между тьххъ горъ; авангардъ составленъ быль подъ гомандою генераль-майора Ласси изъ полковъ п安отныхъ: Днъ̆провскаго, Угличскаго и Витебскаго, Кіевскаго карабинернаго, трехъ эскадронов'ь кирасирь и трехъ тысяч' Донскаго войска казаковъ, подъ гомандою наказнаго атамгана В. ПІ. Орлова ${ }^{111}$ ).

Дъйствительно, непріятель быль изумленъ нечаиннымъ нашимъ появленіенъ, когда онъ думалъ, что мы еще изъ занимаемаго нами наканунъ лагеря не тронулись. Авангардъ въ двухъ кареяхъ заняль два оканчивающихся хребта горь, между которыхъ мы прошли верстахъ въ десяти оть турецкаго лагеря; между сихъ двухъ кареевъ въ лощинъ поставлены были три эскадрона кирасиръ, за ними Кіевскій карабинерный полкъ, а впереди ихъ въ полувер-

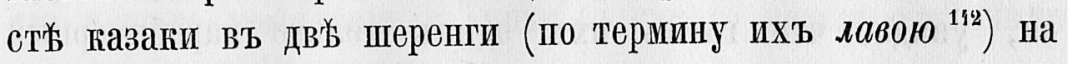
равнинъ, простирающейся не только до турецкаго лагеря, но и до самаго Табағу версть на сорокъ. Весь корпусъ за авангардомъ расположился въ двухъ верстахъ, въ двухъ линіяхъ.

Непріятель выслалъ свою конницу противъ насъ, а прочія его войска стали приготовляться къ отступленію. Картина представилась намь превосходная: Турки разсыпались по полю въ разнообразномъ цвътномъ своепъ одъяніи, на-

141) Василій Петровичъ Орловъ, атамань войска Донскаго, быль женать на дочери наказнаго же атамана Донскаго, графа Өедора Петровича Денисова. У нихь быль сынъ Василій Васильевичь Орловъ, гъ фамиліи котораго присоединены въ 1801 гоцу имя Денисова и графскій титуль. $\boldsymbol{M}$. $\boldsymbol{I}$.

142) Пушиин'ь въ стихотвореніи Делибашв: “Делибашъ, не суйся къ лавъ, пожал范 свие житье). II. $\quad$. 


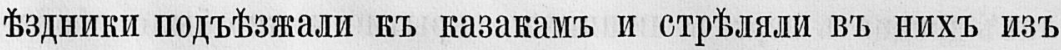
пистолетовъ, наконещь собравшись въ одну толпу, бросились съ обыкновеннымъ ихь крикомь алла, при приближеніи которой, атаманъ, приподнявшись на стременахъ, сняль шапку, перекрестился, что́ и всъ̌ казаки сдь̌⿱宀али. Они встржтили непріятеля на дротикахъ и гикнули съ такимъ стремленіемь, что обратили его въ бжгство; крикь сиьшавшихся казаковъ и Турокь пропввешь ужасную гармонію. Ћіевскій карабинерный полкъ посланъ генералъ-поручикомъ княземъ Г. С. Волконскимъ для подкрьпленія казаковъ. Вдругь убитые Турки раздътыл были донага, и у нась въ пъхотномъ авангардт сдтлалась ярнарка: оружіе разнаго рода, юонскіе богатые уборы и лошади продавались за ничто. Казаки гнали Турогь версты три. Кіевскій полкь, подъ гомандою секундь-майора Гельвига, за отсутствіемь полковника и прочихъ старшихь штабъ-офицеровь, проскакавъ мимо казаковъ и оставя ихъ за собою, поражаль непріятелей, не добзжая версты за двъ до ихъ лагеря. Турки, увидя, что гналь ихъ один'ъ только карабинерный польъ, остановились, и вь свою очередь атаковали нашихъ; храбрый сегундъ-майорь Гельвигъ, видя, что казаки далеко оть него отстали, принуждень быль ретироваться, по временамъ останавливаясь, когда. Турки спльно на него напирали, и такимь образомь соединился съ казаками сь небольшою потерею. Турки отступили въ свой лагерь, и нашей авангардной ґонницй тоже приказано отступить. Еслибы всльъдъ сей нашей кавалеріи весь корпусь двинулся, то вся бы артиллерія; весь лагерь достались бы намъ, и корпусь непріятельскій вовсе быль бы уничтоженъ. Но юнязь Репнинъ, человъћъ надъ-мъру осторожный, думаль, чт0 войска утомились, тогда каюъ всь жадничали сраженія и одушевлены были духомъ храбрости, безотлучной у русскихъ воиновъ. Поле укрыто было убитыми Турками, готорыхъ, конечно, было болье тысячи, а князь Репнинъ по- 
казаль въ реляціи только пятьсоть. Секундъ-майоръ Гельвигь, узнавъ, что въ донесеніи свйтльйшему князю сказано: “Что Ћіевскій полкь только подкрушляль казаковъ», сказаль князю Репнину: «Ваше сіятельство, вы не отдали должной справедливости Кіевскому полку, ибо я гналъ непріятеля до сапаго его лагеря, а казаки оть меня отстали около четырехъ версть, въ чемъ они сами сознаются, и подвигъ мой быль въ виду всего авангарда». Князь съ досадою выговариваль ешу за дерзость и сказалъ, что онъ хогь⿱宀⿰㇇ь было представить его къ повышенію чиномъ. Гельвигъ отвъччаль, что не себя считаль обиженнымъ, но полк'ь, и увърень, что главнокомандующій не откажетъ сдыллать дъъло сіе гласнымъ въ арміи; что касается до него, то онъ при отставкь безъ всякой рекомендаціи получитъ чинъ $\left.{ }^{143}\right)$.

Ћорпусъ оставался въ тотъ день на занятой имъ позиціи. Въ 10 часовъ вечера мы слушали еще обыкновенные турецкіе сигналы, три пушечные выстрбла; но то было только для нашего усыпленія, а Турки съ самаго вечера отступили поспьшно - къ Измаилу.

Сдъљлана была диспюзиція атаковать непріятеля на разсвътть, но уже и сльъдъ его іростыль; послана была кавалерія для преслґдованія, и отнято было ньсколько обозовъ.

Въ два марша достигли мы Јимана въ двънадцати верстахъ оть Измаила. Князь Репнинъ думаль, что крњпость была въ такомь положеніи, какь въ прошлую войну, и хоть⿻ыь взять оную штурмопь; но увидъьљь, что Измаиль быль уже чрезвычайно угртьлень по правиламъ новьйшей Фортификаціи съ каменною одеждою, почему безь формальной осады штурмовать его невозможно; однакожь мечталь, что устрашенный Гассанъ-Паша сдастся, какъ скоро мы

143) За сіе дъљло Гельвигъ получилъ орденъ св. Георгія 4 нласса по представленію свъ̌тльйшаго князя. 
къ Измаилу подступимъ. На другой день по утру подошли щы къ крбепости и ганонировали до трехъ часовь пополудни, въ тақомъ разстояніи, что наши полевыя орудія не могли сдъ̌лать ни мальйшаго вреда; выпустили до двухъ тысячъ ядеръ и гранатъ, на что и намъ изъ гръпости безвредно отвъчали. Посль чего мы отступили сорок'ь верст'ь назадъ, съ такою поспьшностію, как'ь будто непріятель нась гналь превосходными силами.

Свъ̌тлйшій ннязь такт быль недоволенъ сею экспедиціею, что киязя Репнина послаль гомандовать въ 0чаковъ. При Фальч's ${ }^{144}$ ) оставлень быль корпусь подь гомандою генераль-поручика Михельсона изь трехъ полковъ пжхоты, двухъ полковъ кавалеріи, одного полка Донскихъ гозаковъ и десяти орудій артиллеріи. Прочія войска пошли присоединиться къ главному корпусу подь Бендеры.

Въ то время, какь мы дъзали сію пустую экепедицію, Суворовъ однимъ переходомь соединился сь принцешь Кобургенинь и принудиль его тотчас'ь идти атаковать визиря съ своимъ корпусомь, и стать въ авангардь. Корпусъ принца Ћобургекаго быль около 15.000 , Суворова оволо 6.000 , а непріятеля полагали в'ь 80.000. Подъ Рымникомъ союзники одержали совершенную побъду; непріятель потеряль иного убитыми, а еще болье утонувшими въ рььк Рымник', также и пль̌нными; взята вся артиллерія и лагерь. За сію славную побъду Суворовь быль пожалованъ графомь Рымникскимъ.

Въ теченіи сей кампаніи, взята крйпость Аккерманъ на устьћ Днъсстра, а въ исходъ оной Бендеры сдались на капитуляцію.

Войска вступили въ зимовыя квартиры; главная квартира расположилась въ Ассахь, корпусъ графа А. В. Суворова-Рымникскаго въ Фокшанахъ, корпусъ Михельсона въ городъ Фальчё и окружности онаго.

144) Днъ̆провскій полкъ поступилъ въ сей корпусъ. 
Главная квартира пышностію отличалась противъ бывшей подъ омандою графа Петра Александровича. Множество пріьхало женъ русскихъ генераловъ и полковниковъ. Ивъ числа знатнбйшихь были: П. А. Потемкина ${ }^{113}$ ), которой его свъттлость велигое огазываль вничаніе, гр. Самойлова ${ }^{146}$ ), кн. Долгорукая ${ }^{147}$ ), гр. Головина ${ }^{148}$ ), кн. Гагарина $\left.{ }^{149}\right)$; польскаго генерала жена, славившаяся красотою де-Витъ, потомъ бывшая замужемь за графомь Потоцнимъ $\left.{ }^{130}\right)$. Безпрестанно были праздники, балы, театръ, балеты. Хоръ нузыки инструнентальной, роговой и вональной быль до трехсотъ человъ̌къ; извъстный сочинитель музыки г. Сарти всегда оылъ при князъ. Онъь положиль на музыку побъдную пъснь: Тебе Бола хвалимб, и къ оной музыюь прилажена была батарея изъ десяти пушекъ, которая по знанамъ стржляла въ такть; когда же пълли: «свять! свитъ!), тогда производилась изъ оныхъ орудій скорострбыльная пальба.

145) Прасковья Андреевна, супруга Павла Сергъ̌евича, рожденная Загревская. М. Л.

${ }^{146}$ ) Супруга племянника нявя Потемкина. $M$. J.

147) Княгиня Екатерина Өедоровна, рожденная Барятинская. М. Л.

148) Если не ошибаемся, здъсьь говорится 0 графинъ̆ Варварљ Николаевнъ Головиной, рожденной княжнъ Голицыной, супругъ̆ оберъ-шенга графа Николая Николаевича Головина, которому принадлежало славное имъніе Воротынецъ, разыгранное посль его смерти въ лотерего въ 1823 году. $M$. $Л$.

149) Княгиня Прасковья Юрьевна Гагарина, рожденная княжна Трубецкая, жена генералъ-майора князя Өедора Сергъевича. Она родилась 1762 г., ум. 1848; она вышла замужъ по смерти перваго мужа за Петра Александровича Кологривова. Извъстный нашъ писатель князь Петръ Андреевичъ Вяземскій женатъ на ея дочери, кн. Въръ Өедоровнъ̆. $M . Л$.

150) Грашъ Феликсъ Францовичъ Потоцкій, генералъ отъ инфантеріи, ум. $180 \Xi$ г. Эта вторая жена его носила имя СоФіи и была Гречанка. M. J. 
Его свб̌тлость оды̆вался нерьъдко въ гетманское платье, которое спито было щегольски и фасона, который онъ выдумалъ, бывъ пожалованъ гетшаномъ Екатеринославскихъ и Черноморскихъ гозаговъ. Въ самое то время, когда онъ такь щегольски одьввался и такъ нарядощъ своимъ ванимался,

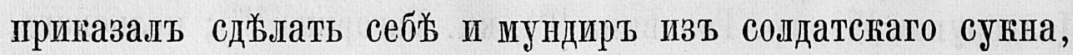
дабы своимъ прииърощъ подать недостаточнымъ ошицерамъ средства не издерживать изъ малаго своего жалованья на покупку тонкаго сукна, которое за отдаленіеиъ торгующихъ купцовъ онымъ товарощъ было дорого. Почему въ угожденіе его всъ генералы сдъзыали тағовые мундиры. И такъ, хотя приказа и не было, но почти всъ штабъ- и оберъ-офицеры съ удовольствіемъ во всю войну одъъвались въ куртки толстаго сукна какъ солдаты; но однакожь не запрещалось по желанію носить мундиры изъ тонкаго сукна.

ПІо прибытіи свьтыљйшаго гнявя въ Яссы, одинъ разъ онъ только быль у фельдмарпала графа Румянцова въ Жижь и изрьдға посылалт дежурнаго генерала, племянника своего B. В. Энгельгардта, съ привйтствіенъ. Остальные генералы изъ подлости и рабольипства рьљдю посъщали графа, да и то самое малое число. Одинъ только графъ Алекс. Вас. Суворовъ оказываль ему уваженіе; посль всякаго своего дъъла и движенія, посылая пурьера съ донесеніемъ главнокомандующему, особеннаго курьера посылаль съ донесеніемь и къ престаржлому фельдмаршалу, такъ какъ бы онъ еще командовалъ арміей.

Въ теченіе зимы Бендерская прйпость взорвана.

1790. Въ 1790 году императоръ Іосифъ II умеръ; императорь Леопольдъ ${ }^{151}$ ), вступая на престоль, заключиль миръ,

151) Императоръ Леопольдъ II, братъ ІосиФа II, род. $ّ$ мая 1747 г.; съ 1765 былт великим герцогомь тосканскимт, а императоромь римскимъ с'ъ 1790 года. Въ августь 1790 года онъ заключилъ съ Тургами перемиріе, а черезъ годъ миръ въ Чистовъ. Онъ умеръ 1 марта 1792 года. $M$. JI. 
для Австріи вовсе невыгодный. Французская революція тогда была въ самой ужасной анархіи.

ІІведскій флоть, на готоромь быль самъ король, и который состояль въ 26 корабляхь и фрегатахъ, атаковаль ревельскій нашъ флоть, въ которомъ не болье было десяти кораблей при самомь ревельскомъ рейдъ, подъ командою адмирала Чичагова ${ }^{132}$ ); онъ не только быль отраженъ, но потеряль одинь фрегатъ. Оставя оный, корошь пошелъ противъ Кронштадта, подъ командою адмирала Крузе ${ }^{133}$ ), имбыль большую поверхность, но гогда оба наши флота соединились, то шведскій флотъ и съ гребною флотиліею загнанъ былъ нежду острововъ и былъ въ таконъ положеніи, что ожидали, или что Флоть должень быль сдаться, или быть сожженъ. Въ тагошъ положеніи онъ быль болье двухъ недъљь; наконецъ въттеръ сильный епу поблагопріятствовал'ь; пустивь передъ собою брандерь, онъ открыль себъ выходъ, но хотя онъ и вышель, но собственный его брандеръ стегъ у него два корабля, и отъ нашего флота повреждено еще два; множество изъ гребнаго его Фцота потеряно судовъ и людей. За тймъ принцъ Нассау съ нашею Флотиліег одержаль большую побъду надъ флотиліею шведскою. Сухопутная наша армія дъйствовала неудачно, почену оть командованія ариіею въ Финляндіи генералъ Пушкинъ отозванъ, а виъсто его поручено главное начальство генералу барону Игельстрому.

Ћогда шведскій фшоть быль запертъ, генераль Кречетников'ь ${ }^{154}$ ), управлявшій тогда малороссійскими губерніями,

152) Василій Яковлевичъ Чичаговъ, адмиралъ, род. 28 октября 1726, ум. 4 апрьљля 1809. Сынь его Василій Васильевичъ былъ морским' министрощъ. $M$. JI.

133) Александръ Ивановичъ Крузе, адмиралъ, род. 26 огтября 1727 ,

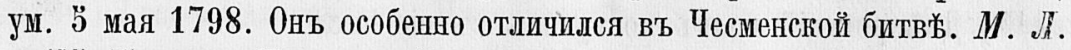

151) Михаиль Никитичъ Кречетниковъ, генералъ-аншефъ, ущ. 9 мая 1793 г. M. II. 
услышаль отъ какого-то шроъзжаго изъ Петербурга, что будто шведскій флоть сдался. Съ симъ пріятнымь извъсті-

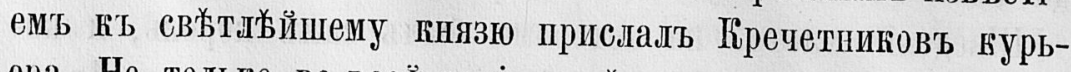
ера. Не только во всей арміи стрбуляли викторію, но свъьтльйшій князь о сей мнимой побъдь отправиль курьера кь австрійскопу императору. Чрезъ ньсколько дней Кречетниговъ прислаль извиненіе, что по слухамь донесь о том' ложно. Курьеръ съ симъ извъсстіенъ прибыль во вреия объда; князю чрезвычайно было прискорбно, что долженъ быль послать курьера къ императору о таковой скоро-поспъ̌шной неосмотрительности. Князь сталь бранить Кречет-

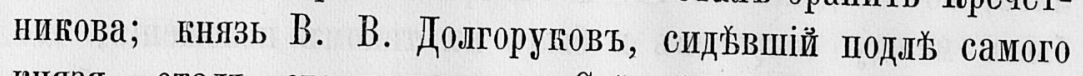
князя, сталь его защищать. Свътьлйшій князь до того разсердился, что вышель изь себя, схватилъ Д. за георгіевскій крестъ, сталь его дергать и сказаль: «Кақь ты смкешь защищать его, ты, которому я изъ милости даль сей орденъ, гогда ты во время пгтурма 0чаковскаго струсиль»? Вставши изъ-за стола, подошель князь къ австрійскимъ генераламъ, на тоть разъ туть бывшимь и сказалъ: "Pardon, messieurs, je me suis oublié; je connois ma nation et je l'ai traité comme il mérites $\left.{ }^{13:}\right)$. Cie случилось въ Яcсахъ при самомъ отбытіи в'ъ Бендеры.

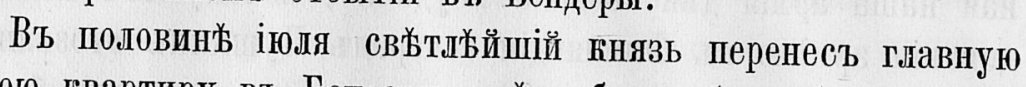
свою квартиру въ Бендеры, гдъ собрано было болышое число войскъ $\left.{ }^{156}\right)$. Графъ Суворовъ занималъ Фокшаны; генералъ-поручикъ Потемкинъ получиль въ командованіе корпусъ, состоявшій при Фальчй, который значительно быль усиленъ.

Во время сихъ происшествій фаворитъ Мамоновъ женился ${ }^{137}$ ),

$\left.{ }^{133}\right)$ Т. е.: Извините, господа, я забылся; я знаго нашъ народъ, и съ нимъ обошелся такъ какъ онъ заслуживаетъ.

136) Днъ̆цровскій полкъ поступиль въ сіе число.

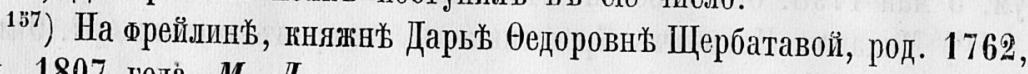
ум. 1807 года̇. $M$. .I. 
а его мъсто заняль П. А. Зубовт ${ }^{138}$ ), который потонь пожалованъ быль свьтльйшигь княземъ, а братья его графами. По кончине князя Г. А. Потенгина, былъ онъ столько же, кағъ онъ, силенъ, не имъвъ его генія.

Въ псходъ сентября посланъ быль большой горпусъ подъ гомандою артиллеріи генералъ-аншефа И. И. Меллера-Зақомельскаго ${ }^{159}$ ) къ Киліи. Какъ Днъпровскій полкъ получиль въ укомпектованіе рекруть, заразивпихся гровавымъ поносомь, а потому въ походъ идти былт не въ состояніи, т0 перешель я во вновь сфориированный изъ Санкпетербургскаго полка Свят0-Николаевскій полюъ, поступившій въ горпусъ генерала Меллера.

Корпусъ, не доходя упомянутой гржиости версть за десять, имъль роздыхъ. Въ ночь командированъ быль генеральъ-поручиц'ь Самойлов'ь ${ }^{160}$ ) для занятія ретраншамента, оголо сей грьиостн расположеннаго. Самойловъ раздъљлиль свои войска на три колонны: правою голонною командоваль бригадирь (конно-грепадерскаго полка, что́ былъ Молороссійскій гренадерскій, но еще не снабженный лопағьми) Василій Сергъевичъ Шереметевъ. Среднюю юолонну вель самъ Самойловъ. Лжвою гомандоваль храбрый генералъмайоръ Мекнобъ. Передъ выступленіемъ, Самойловъ созвалъ голонныхъ гомандиров'ъ и полковниковъ и объявиль имъ, чт0 какъ по върнымъ пзвъсстіямъ весь гарнизонъ и сь жителями въ Киліи не болье быль пяти тысячъ Туроґъ, то ежели они выгнаны будутъ изъ ретраншамента, нужно стараться на плечахь Турокь войдти въ крњпость; это

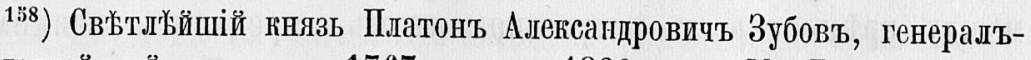
Фельдейхмейстерь, род. 1767 г., ум. 1820 года. $M$.

${ }^{139}$ ) Баронъ Иванъ Ивановичь Меллеръ-Закомельскій, генераль оть артиллеріи, ущ. 10 октября 1790 года.

160) Графъ Александръ Николаевичъ Самойловъ, въ посльдствіи генераль-прокурорт, быль по своей матери роднымъ племянникомъ князя Потемкина. $\boldsymbol{M}$. $\boldsymbol{d}$. 
легко могл0 бы быть, еслибы Турки и занимали ретраншаментъ.

Ве’, будучи заняты тақовою мыслію и таковым' предпріятіемъ, шли съ рьшительною бодростію. Ночь была самая темная; къ несчастію, ретраншаментъ быль очень обпиренъ для малочисленнаго гарнизона, а потому гакъ оный, такъ и форштать Турками были оставлены.

Средняя голонна прежде другихъ дошла къ ретраншаменту, и какъ Самойловъ не нашель туть непріятеля, то и приказалъ войску, голову голонны составлявшему, загричать: «ура»! Прочіе, бывшіе въ хвость, принявъ сигналъ “ура», думали, что непріятель побжжаль, опрокинули голову колонны и бросились къ грбпости, не слушая ни генерала, ни прочихъ свопхъ командировъ. Правал колонна, услыша “ура» средней, бросилась также кь крњпости. Јъвая колонна одна удержала порядокъ, заняла ретраншаментъ и расположилась въ ономъ.

Килія построена на клине Дуная, и сія великая ръка гакъ бы составляла ея Фланги, готорые прикрыты были по об̆ииғь сторонаиъ флотиліею. Наше войск0, бывшее въ разстройствљ, встрьчено было изъ круьпости пушечными картечными выстржылаи и ружейнымъ огнекъ, а съ флотиліи ядрами. Въ такомь несчастномъ отпорб, претерпььвая спльныя пораженія, бросились наши войска къ лйвой части ретраншанента, занятаго колонною генераль-майора Мекноба, которая шриняла своихъ за Турокъ и открыла по нимъ ружейный огонь. Тогда безпорядокь сдъълался общій; солдаты вышли изъ повиновенія, разбрелись по форштату, бывшему между крьиостью и ретраншаментомь, предались всяким'ь неистовствамъ, перегололи всъхъ Армянъ и Грековъ и ворвались въ армянскій монастырь, истребляя и опустошая все, что́ ни попадалось.

Между тънъ весь корпусь подошель іп заняль лагерь верстахъ въ четырехъ отъ крьпости. 
Ћомандующій генералъ съ прочими генералами взошли на случившійся передъ лагеремь гурганъ, възтеръ былъ ужасно сильный со стороны лагеря; ни одного выстрь⿻ыла не было слышно, но мельканія огня на подобіе фейерверка представляли видъ удивительный. Генералъ бевпрестанно посылаль къ Самойлову узнать о причин'ъ вид'вннаго, но Самойловъ, думая привести въ порядокъ войска, посланныхъ удерживаль при себъ. Наконець начало свъттать; полковниюь принцъ Филипштальскій ${ }^{161}$ ) прибыль отъ Самойлова съ донесеніенъ 0 случившемся и 0 томъ, что онъ не можетъ привести въ порядоґъ разстроенныя войска.

Иванъ Ивановичъ Меллеръ отправился самъ, приказавъ нарядить свъжія войска. Когда онъ прибыль въ форштать, встрйтилп его солдаты въ разбродъ: “Батюшка, вели поставить пушки, выломить ворота, мы тотчась крґпостію овладъенъ .- «Хорошо ребята, говориль онъ, подите назадъ въ ретраншаментъ, а то вы мьшаете стрьлять изъ пушекъ». И такъ мал0-по-малу войска приходили в' должное повиновеніе; но лишь только генераль покавался на площадь противъ крь̆пости, какъ роковая пуля попала ену въ звъ̌зду и прошла на вылеть наискось черезъ весь его корпусъ; отнесли его въ лагерь, где́ чревъ нёсколько часовъ онъ и умеръ.

Новыя войска заняли ретраншаментъ, а прежнія выведены въ лагерь. Много было убито и ранено офицеровъ; нижнихъ чиновъ убйо слишкомъ пятьсотъ человъьъ, а ранено еще болте; въ числь' раненыхъ быль бригадиръ Шереметевь легко въ ногу, однакожь во все время осады Киліи не могъ служить. Начальство надъ горпусомь принялъ генералъ-поручикъ И. В. Гудовичъ ${ }^{162}$ ).

161. Тоть самый, который столь славно защищалъ прӗпость Гаэту въ Неаполитанскомъ горолевств' оть Французовъ.

162) Графъ Иванъ Васильевичь Гудовичъ, фельдмаршаль и главно- 


\section{$-112-$}

На другой день занять былъ отчасти выжженный форштатъ, гды во вреня канонады укрывались оть ядеръ. Сдъланы были батареи, одна для отдаленія флотиліи отъ крњпости, а другая противъ самой кръпости и кегель-батарея. Канонады были ужасно сильныя съ крљ̆ости и съ об̆ъихъ Флотилій, такъ чт0, признаюсь, съ первой мною вытерплььнной канонадой, я только и думаль, какъ бы сказаться больнымъ, a посльъ выйдти в'ь отставку. Однако стыдно было показать себя трусомъ: я ржшился продолжать ходить въ Форштатъ, но объ отставкь все еще не отлагаль намъренія; въ третью канонаду уже и то отдумалъ, и тагь привыкъ къ свисту ядеръ и бомбъ, канъ бы бывалъ на простомъ артиллерійскомъ ученьи. Ко всешу можно привыкнуть, и храбрость также опытомь пріобржтается, какь и всъ другія добродьттели.

Чрезъ шесть дней сджылана была брешъ-батарея въ 60 саженяхъ оть грьпости, на которой поставлено было десять 24-хъ-фунтовыхъ пушекъ, два картаульные единорога, пять мортиръ разныхъ галибровъ и 48 кугорновыхъ. Для откерытія сей батареи ожидали прибытія свттытыйшаго внязя, но чрезъ пять дней, накъ онъ отказался самъ быть, проивведена была изъ оной пальба залпами. Командоваль оно10 батареею артиллеріи-капитанъ Секеринъ. Въ двое сутокъ брешъ была сдхълана; цълая башня до фундамента была опровергнута; паденіемь оной ровъ совершенно быль засыпанъ; уже́ назначень быль штурмъ, гаћъ въ ту же ночь Турки выслали парламентера, и крљипость сдалась на капитуляцію. Гарнизону позволено на своей Флотиліи отобыть къ Измаилу, также и всъиъ жителянь Турғамъ сь ихъ женами, семействами и имуществомь, но веъхъ невольни-

гоманцующій въ Москвъ (1809-1812), род. 1741, ум. 1820 г.; сынъ его графь Андрей Ивановичъ оберъ-егермейстерт, столь извъ̌стный Москвъ, уМ. 1867 г. М. Л. 
гов'ь-христіянъ должны они были оставить. Поутру четыре баталь0на встунили въ връпость; комендантомь сдъљанъ былъ генералъ-майор'ь Мекнобъ; и тагъ, чрезъ двъ̆ недъ̆ли отъ несчастнаго занятія ретраншамента, Килія взята 18 октября. По занятіи ея, наша Чернонорская флотилія прибыла съ Запорожцами ${ }^{163}$ ); ею командоваль походный войсковой кошевой Головатый, котораго Запорожцы не любили за то, что онъ зналь грамоть' и называли его письменнныль.

По занятіи Киліи, полкамъ: Екатеринославскому, потораго свъัтлйшій князь быль шефомъ, конно-гренадерскому и

163) Запорожскіе казаки именовались такъ потому, что жили за Днйпровскими порогами. С's давнихъ временъ они зависьли отъ малороссійскихъ гетмановъ, но по отдаленности часто передавались въ покровительство Польши, иногда крымскимъ Татарамь, а иногда Туркамъ. Во время измъны Мазепы съ нимъ многіе ушли въ Турцію. Въ посльднее время они принадлежали Россіи. Съчь ихъ была при устьъ Самары, впадающей въ Днь̆рь. Съчь пропсходить оть слова заспка, ибо они всегда оною укрьнлялись. Всякой націи люди и всякаго званія ими принимались; управлялись они своимъ кошевымъ (оть слова кошъ), письменныхъ законовъ они не имъли, но по преданію порядокь учрежденный твердо хранили; подобно мальтійскимъ кавалерамъ, всъ были холосты; хотя многіе изъ нихъ были женаты, но жены ихъ были въ отдаленіи отъ Съччи, и не смьлли ихъ туда привозить; сіи поселенія внъ Съчи назывались зимовьемъ. Въра ихь была ГрекоРоссійская. Церкви ихъ были богато уграшены; жили они промысломъ рыбнымъ, а болье грабежомъ въ Польской Украйньь, а потому ивъ польскихъ господъ въ томъ праю мало живали. Но когда посль турецкой войны 1773 года Днъпръ до самаго устья сталъ принадлежать Россіи, то СЪ̆qь уничтожена. Запорожцы употреблялись на службу наравнъ̌ съ малороссійскими казаками, но ихъ флотиліи много сдълали пользы, а сухопутные Запорожцы были самое худое войско, безъ мальйшей дисциплины. Императрица пожаловала имъ по огончаніи сей войны на Черномь морь островь Тамань; названы они уже Черноморскими казаками и иричислены къ Таврической области, но управляются своимъ кошевымъ, состоя подъ вйдомствомъ военнаго министерства. Главный городъ назвали они Екатеринодаромъ. 
Свято-Ниқолаевскому съ осадною артиллеріею, вельнно было идти къ Бендерамъ, а прочимъ войскамъ къ Измаилу, подъ начальство графа Суворова, шедшаго къ оному съ большимь корпусомь ${ }^{164}$ ).

Его свйтлость большія тогда дйлалъ угожденія кн. К. $\theta$. Долгоругой. Между прочими увеселеніями сдъ̌лана была землянка противу Бендерь за Днъстромъ. Внутренность сей землянки поддерживаена была ньсколькими колоннами и убрана была бархатными диванами и всъмъ тъ̌мъ, что́ только роскошь мотеть выдумать. Изъ великоль̈пной сей подземельной залы, особый быль будуаръ, въ который только входили тъ, кого князь самъ приглашалъ. Вокругъ землянки кареемъ поставлены были полки: Екатеринославскій й конногренадерскій, имъя ружья, заряженныя холостыми патронами, и въ сумахъ по 40 патроновъ на каждаго человйка; близь онаго карея поставлена была батарея иво ста пу-

164) Туда же свьътлъйшій князь отправилъ трехъ гвардіп офицеровъ Ч., Ц., Т., присланныхъ императрицего въ армію, чтобъ они васлужили и омыли своею гровіг огазанную ими трусость во время сраженія нашей флотиліи противъ ШШведовъ подъ начальствомъ принца Нассау. 0ни, командуя однимъ судномъ, въ самое жаргое сраженіе вышли на островъ; а сержантъ гвардіи Руничъ, бывшій на ономъ, оказаль большуго храбрость. Принщъ Нассау, замьтя оное, спросиль: кто начальнигъ сего судна, и не мало удивился, что то былъ сержантъ. Спросилъ: гдъ же офицеры? и когда узналъ 0 ихъ подломъ поступкъ, донесь государынъ. Посль штурма они всъ трое получили георгіевскіе
кресты. Л. $尹$.

Въ Запискахъ Храшовицгаго, подъ 22-иъ числонъ августа 1789 г. читаемъ: «Терскій несчастный отецъ! одинъ сынъ убить, другой.... будетъ наказанъ за то, что оставя команду, ушель съ галеры Пусталчи. Преображенскіе гапитанъ Чертковъ съ прапорщикомъ Терскимъ и подпоручигомъ Цезырскимъ ушли на берегъ при началь сраженія. Tрое сержантовъ: Тюнинъ, Руничъ и кн. Елымовъ командовали галерог во время сраженія. Они пожалованы гвардіи въ поручики». Терскій быль генералъ-рекетмейстеромъ при государынъ. П. Б. 


\section{$-115-$}

шећъ; обоихъ полковъ барабанщини собраны были къ землянкъ. Однажды, князь вышелъ изъ землянки съ кубқомъ вина и приказаль ударить тревогу по знаку, по которому, какъ полками, тагъ и изъ батареи произведенъ былъ батальный огонь; тьимъ и гончился праздникъ въ землянкъ. 0днажды княгиня сказала, что любитъ цыганскую пляску. Князь Григорій Александровичъ узналъ, что бывшіе въ Ћонногвардіи вахмистры два брата Ћузмины, выпущенные ротмистрами въ кавказскій корпусь, мастера плясать по-цыгански, приказаль за ними послать, и когда ихъ привезли, одъъли одного изъ нихъ цыганкою, а другаго цыганомъ. На одном'ь баль' сдъљанъ быль для княгини сюпризъ, и должно отдать справедливость мастерству гг. Кузминыхъ: я лучшей пляски в' жизнь мою не видывалъ. Такъ поплясали они недъ̌зи съ двъ̌ и отпущены были въ свои полки на Кавкавъ, съ т0ю только для нихъ пользою, чт0 продиздъ ищъ ничего не стоиль ${ }^{165}$ ).

165) Много таковаго своенравнаго его обычая случалось въ его жизии: такъ напримъ̌ръ, бывши въ Петербург'ъ, узналъ онъ, что въ Херсонъ какой-то чиновникъ хорошо передразнивалъ нйкоторыхъ извьсстныхъ лицъ; тотчасъ отправилъ онъ за нимъ курьера; какъ скоро тотъ

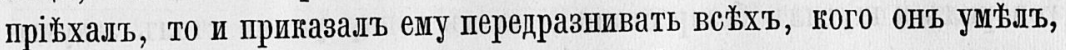
потомъ и самого себя. Его свътлость, позабавившись таковымъ дарованіемъ, пригазаль елу отправиться въ свое мйсто. Бывши подъ 0чаковымъ, услышалъ онъ, чт0 нъ̆кто г. Спечинскій, жившій въ Москвъ̌ въ отставкъ, знаетъ наизусть всъ святцы, т0-есть какого святаго каждаго мъсяца и числа. Тотчасъ онъ послаль за нимъ; тотъ, получивши отъ свйтльйишаго князя приглашеніе, пумалъ, что какъ безъ Ахиллеса не могла взята быть Троя, такъ и безъ него не можетъ быть взять 0чаковъ. Съ восторгомъ принялъ онъ тотъ зовъ,

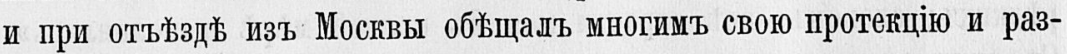
ныя милости. Когда онъ явился къ его свъ̌тлости, то ннязь его спросилъ: правда ли, что вы знаете наивусть всъ святцы? И по утвер-

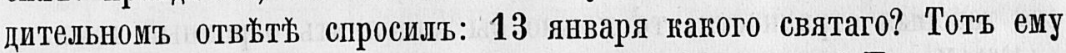
отвъ̆чал'ъ. Князь справился съ святцами. А 10 Февраля? Потомъ спро- 
Въ то время, когда в' Бендерахъ занимались разными праздниками и веселостями, графъ Суворовъ атаковаль Измаилъ, требоваль сдачи, а по отказъ на третій день взяль его штурмомъ $\left.{ }^{166}\right)$. Крьпость важная обороняема была тридцати-тысячнымъ гарнизономъ; русснихъ же воиновъ, гонечно, было менъе сего числа. Съ нашей стороны потеря была велика: убитыхъ было около 10,000 человьькь, въ числ'ь которыхъ былъ генералъ-майоръ Мекнобъь, много штабъ- и оберъ-опицеровъ. При штурмь отличиль себя Полоцкаго полка священникъ; подполковниюъ Яцунскій, командиръ сего полка, быль убить, полкъ поббжалт; тогда

силь по одному числу въ каждомъ мъсяцћ̆. «Какая счастливая у васъ память! Благодарю, что вы потрудились прівхать; можете отправиться въ Москву, когда вамъ угодно».

Въ бытность мою у него адъютантомь, въ одинъ день спросилъ онъ коФею; ивъ бывшихъ туть одинъ вышель приказать; вскорь спросиль опять гофею, и еще одинъ поспьшилъ выйдти приказать 0 томъ; наконецъ безпрестанно просиль кофею; почти всъ по одному спьшили приказать по его нетерпъливому желанію; но какъ скоро принесли кофей, то князь сказалъ: «Не надобно, я только хотбъль чего-нибудь ожидать, но и туть лишили меня сего удовольствія).

Въ одинъ день князь сълъ за ужинъ, былъ очень весель, любезенъ, говорилъ и шутиль безпрестанно, но кь конщу ужина сталь задумываться, началъ грызть ногти, что̀ всегда было знакомъ неудовольствія, и наконецъ сказаль: «Можетъ ли человькъ быть счастливъе меня? Все, чего я ни желаль, всъ прихоти мои исполнялись, какь оудтто какимъ очарованіемъ: хотьљъ чиновъ-имь̆ю, орденовъ-имьью; любиль играть-проигрываль суммы несчетныя; любиль давать праздники - давалъ великольпные; любиль покупать им'ннія - им'юю; любиль строить дома-построил'ь дворцы; любиль дорогія вещи - им'ью стольго, что ни одинъ частный человъ̌къ не имъетъ такъ много и такихъ

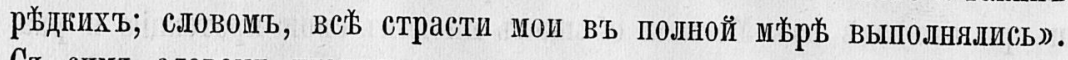
Съ симъ словощъ удариль фарфоровою тарелкою объ поль, разбиль ее въ дребезги, ушель въ спальню и заперся. Если записывать всъ его таковыя странности, т0 можно бы наполнить огромный томъ.

166) Измаиль взять 11 декабря 1790 года. M. II. 
тоть попъ съ крестомъ въ рукахъ закричалъ: “Стой, ребята! Воть вашъ командиръ) (указывая на кресть), и самъ бросился передъ полкомъ къ крьпости; полкь пошель за нимъ, и священникъ, изъ числа первыхъ, взошелъ на стьнну, за что́ награжденъ быль наперстнымъ золотымъ крестомъ на георгіевской ленть. Ћомендантомъ Измаила сдъљланъ былъ Михаиль Ларіоновичъ Кутузовъ, пожалованъ былъ генералъпоручикомь, и поручены были ему всъ войска, занимавшія местость оть Киліи до Берлата. Графъ А. В. Суворовъ отправился въ Петербургъ, по желанію императрицы видёть сего героя.

По взятіи Измаила, войска введены были въ зимовыя квартиры уже 23 декабря. Время было прекрасное. Сль̈дуя съ полкомъ въ Ботушаны 24-го, при захожденіи солнца, сидь̌лъ я на дворь въ одномъ мундиръ, распахнувпи камзолъ.

Подъ исходъ кампаніи, принцъ Нассау быль разбить шведскою флотиліею; на сухомъ пути тоже не было удачи, и, къ общему сожальнію, быль убить отличныхъ дарованій генераль-поручикъ принць Ангальть-Бернбургъ, родственникъ императрицы. Въ теченіи зимы со Шведами заключенъ миръ; объ воющщія державы остались въ границахъ своихъ государствъ въ такомъ положеніи, въ какомъ были до начатія войны.

Въ началь' кампаніи, кавказскій корпусъ, подъ командою генералъ-поручика Биоикова ${ }^{167}$ ), безъ повел'нія и не имгоя побудительной причины, сдылалъ экспедицію подъ Анапу и съ большищъ уронощъ возвратился. Начальство отъ Бибикова отнято, а корпусь порученъ генераль-щайору Герману ${ }^{168}$ ), который разбилъ Баталь-пашу, вредившаго намъ,

167; Юрій Богдановичъ Бибиковъ генералъ-поручикъ. М. J.

168) Баронъ Иванъ Ивановичъ Германъ, генераль оть инфантеріи. 0нъ былъ разбитъ и взять въ пль̌нъ Французами въ Голландіи въ. 1799 году. $M . ~ Л$. 
склоняя Черкесъ къ нападенію на наши границы. Посль взятія Киліи, посланъ туда главнымъ командиромъ И. В. Гудовичь.

1791. Въ наступившій 1791 годъ, въ исходљь января, его свътлость отправился въ С.-Петербургъ, поруча армію за отсутствіемъ своимъ князю Николаю Васильевичу Репнину.

Въ начал'ъ весны дъланы были двъ экспедиціи за Дунай: генералъ-поручикъ II. Л. Кутузовъ подъ Исакчу и Бабадай, а генераль-поручикъ князь С. $\theta$. Голицынь ${ }^{169}$ ) подъ Мачинь; оба возвратились, имгьъ всюду поверхность надъ непріятелемь.

Командующій арміею князь Репнинъ стянуль всь войска къ Дунаю и расположиль въ лагеряхъ по Серету. Главный корпусь стояль при Галащ'; оть онаго въ 10 верстахъ корпусъ князя Голицына; отъ онаго большой отрядъ генераль-майора Милашевича, тоже въ 10 верстахъ; отъ онаго въ такошъ же разстояніи при Сербаняптяхъ корпусь генеральь-поручика князя Г. С. Волконскаго.

Визирь сабраль большую армію и расположился въ крьпкой позиціи и укрьпленномъ лагерь при Мачинё:

Ћнязь Репнинъ рбшшился атаковать его; въ ночь 23 іюня, главный корпусъ сталь переправляться чрезь Дунай, не снимая лагеря и оставя въ ономъ всъ тягости; по переправъ главнаго корпуса, переправился корпусъ князя Голицына, потомъ отрядъ Милашевича, а 26-го корпусъ князя Волконскаго. Переправа всегда была дълана ночью на Флотиліи, которою начальствоваль генералъ-майоръ 0 . М. де-Рибась ${ }^{170}$ ).

169) Князь Сергъй Өедоровичъ Голицинъ, ген. оть инфантеріи, род. 20 августа 1748, ум. 20 января 1810. 0нъ быль женатъ на Варваръ Васильевнъ Энгельгардтъ, родной племянницъ князя Потемкина. Ћъ ней написана Державинымъ знаменитая ода: Осень во время осады Оиакова. M. I.

170) Осипь Михайловичъ де-Рибасъ, адмиралъ, ум. 1800 г. Онъ поступиль в'ь русскую службу въ 1772 году, повнакомившись тогда 
Днемъ за Дунаемъ войска скрывались въ камышахъ, и во все время нашего пребыванія не позволено было имъ̌ть огня, чтобъ оставить Турокъ въ невъдъніи 0 нашей переправъ. Јагери оставались неснятыми на своихъ мъстахъ, съ своими тягостями, небольшимъ числомъ оФицеровъ и слабыми людьми, қоторые не могли сльдовать за арміею; тақже оставлено было нъъготорое число барабанщиковъ и въ каждощъ лагеръ по одной пушкё для выстрбловт къ вечерней зоръ.

Переправившаяся армія состояла изъ 33,000 человъььь, кромъ иррегулярныхъ войскъ, съ шести-дневнымъ провіянтомъ; таковаго числа войскъ виъсть̌, во время турецкой войны, никогда не бывало.

27 числа, генералъ-қвартершистръ лейтенантъ Медеръ, съ легкими войсками посыланъ былъ рекогносцировать непріятельскій лагерь. По открытіи имъ непріятельской позиціи, положено было атаговать турецкую армію сльвдующею диспозиціею. Того же дня, въ 7 часовъ по-полудни, генералъпоручику Кутузову съ 13,000 , составлявшими лъвый Флангъ, должно было выступить и обойдти ц炈 горъ, простирающихся версть на пять параллельно по Дунаю и примыгающихъ къ непріятельскому лагерю съ л'ввой его стороны. Въ 9 часовъ приказано было выступить двумя колоннами: правая голонна, подь командою генерала гнязя С. $\theta$. Голицына, должна была идти близь Дуная; средняя колонна, подъ командою генералъ-поручика князя Волконскаго, взять львьъе. Сльъдовало выдти на равнину объимъ голоннамъ между Дунаемь и сказанною цъыню горъ и выстроиться въ двъ линіи кареями, но не прежде показаться изъ-за камышей, какь когда уже корпусъ Кутузова покажется на горь и на фланге турецгаго лагеря.

Ночь была чрезвычайно теиная, что́ способствовало на-

съ графомъ Алегсъенъ Григорьевичемъ 0рловымъ въ Јиворно. Рибасъ покорилъ городъ Хаджибей и построиль на его пъсть одессу. М. Л. 
IIему скрытному маршу; разстояніе отъ переправы до Мачина было оголо 30 версть ${ }^{171}$ ).

Только лишь начало разсвътать, мы приблизились къ

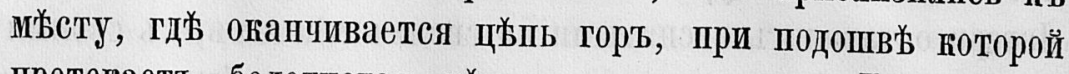
протекаетъ болотистая ръччга, впадающая въ Дунай; брошшены были по оной портативные мосты, по готорымъ безпрепятственно переправились. Камыши этой рйчки такь часты и высоки, что человь̌къ человъьға едва могь видъть.

Ћорпусъ князя Голицына едва показался изъ камышей, какъ былъ атакованъ большичь числомъ янычаръ, съ ихъ обыкновеннымъ страшныщъ крикомъ: алла! алла! Bó время открытою картечною пальбою были они отражены; тогда они бросились на гору и заняли оную, такъ что мы отъ корпуса Һутузова были отдъљлены, а онъ на горахъ не показывался. Наш'ь корпусъ выстроился версты за три отъ непріятельскаго лагеря, откуда изъ большихъ орудій стрђляли въ насъ ядрами; съ горы анфилированы были наши войска, а съ правой стороны была турецкая флотилія; въ тақомъ непріятномь положеніи мы были три часа.

За горою слышна была сильная канонада. Князь Репнинъ послаль своего адыотанта юь Кутузову узнать, что тамь происходитъ, и для чего онъ не всходитъ на гору? Должно было объъхать всю эту цйьь горъ, на что требовалөсь иного времени; а каюъ вьтеръ усилился и дуль отъ насъ, то ғазалось, что ганонада отдалялась. Князь Репнинь былъ въ большомь безпокойствъ, ть̌мь болье что перешель Дунай вопреки желанію свътылйшаго князя, взявъ на свою собственную отвътственность. Многіе генералы, зная т0, желали сды.лать ему угодное; одинъ изъ нихъ говориль князю, что ежели Кутувовъ принужденъ будеть отступить и будетъ разбитъ, тогда могутъ отръъать насъ отъ нашихт

171) Во время нашего марша на флотиліи сдйланъ былъ мость отъ Галаца на островъ Конщефану, а отъ онаго на противолежащій берегъ. 


\section{$-121-$}

щостовъ, и ииъя съ собою провіянта только на три дня, армія будетъ въ худшемъ положеніи, нежели Петръ Великій быль при Рябой Могиль. Уже князь и самъ 0 тощъ помышлялъ; онъ, который быль всегда болье нежели ост0роженъ.

Наконецъ возвратился посланный отъ Кутузова, который приказалъ сказать, что онъ имҺетъ предъ собою великія силы, препятствующія ему взойдти на гору. Князь хоть̈ль было уже ретироваться, каґъ князь Г. С. Волконскій, его зять, уговориј'ь его, чтобы намъ самимъ взойдти на гору. Счастливая была минута сего совъ̌та. Генералъ подьъххалъ къ Свято-Николаевскому полку, бывшему у самой горы: «Господинъ польовникъ! сказаль онъ, прикажите своимъ резерванъ атаковать гору». Я подскакальь и сказалъ: «Ваше сіятельство, Удостойте приказать мнь сію честь исполнить.» - «Съ Богощъ, другъ мой», сказаль онъ мнъ. Тогда я вывелъ изь каре резервы нашего полка, спьшился и закричаль: «Ребята на штыки! ура!) Съ большою храбростію за мной они бросились; всльъдъ за мною Свято-Николаевскій полюъ, а за нимъ Малороссійскій гренадерскій. Гора очень была крутая, обросшая терновникомъ, однакожь ничто насъ не остановило. Взошедъ на гору, взли туть брошенную непріятелями пушку. Непріятели, увидя, что наши войска

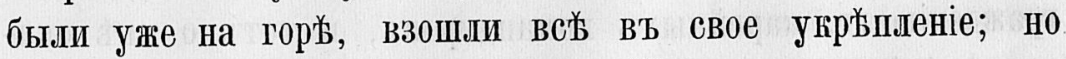
артиллерію трудно было взвести. Меня командировали за пушками, и кое-какъ людьши втащиль я нессколько, пока нашли удобное мьсто взвести батарейную артиллерію. Тогда и Кутузовъ со всъиъ своимъ корпусомъ къ намъ присоединился ${ }^{172}$ ). Учредя батарею, стали стрёлять въ турецкій

172) М. Л. Кутузовъ могъ взойдти на гору безъ труда и показалъ ложно; что противъ его большія были силы; даже генералъ квартермистрь Пистеръ, бывшій вт его корпусъ, при многихъ дерзко его въ томъ уличалъ. Думать надобно, что Кутузовъ зналь коротко свойство 
ретраншаментъ. Ћъ счастію, гранатою зажженъ былъ большой пороховой на непріятельскихъ батареяхъ магазинъ, котораго взрывъ такъ устрашилъ Турокъ, что они поббжжали: тъмъ и баталія сія выигрына. Князь Волконскій послаль меня къ князю Репнину поздравить съ побъдою.

Мы взяли весь лагерь, сорокъ пушекъ, множество съљстныхъ припасовъ, даже находили во многихъ мйстахъ варившееся кушанье и кофей. На другой день принесенъ былъ благодарственный молебенъ на мйсть побъды, и мы возвратились за Дунай, въ прежніе свои лагери.

Веъ знакомые мои меня поздравляли, что мнё удалось въ виду всей арміи показать готовность пь службъ, и увъ̌рены были, что такъ какъ я первый, такъ сказать, способствоваль гъь одержанію побъды, то и буду отлично награжденъ. По обыкновенію, всъ ходили въ канцелярію князя Репнина къ управляющему оною подполковнику Панкратьеву ${ }^{173}$ ) справляться и искать помощію его быть хорошо рекомендовану; я никогда не любиль таскаться по канцеляріямъ и находить себъ покровительство отъ управляющихъ оными. Зналъ, что главнокомандующій былъ очевиднымъ свидъ̌телемъ, зналъ, что командующій центромъ, рекомендуя своего дежуръ-майора и при немъ находящихся, свидбетельствоваль въ справедливомъ представленіи юъ награжденію гг. карейныхъ командировъ, и тоть о мнъ сказалъ, что́ и какъ я поступалъ; потому я и не хоть̆ль болье 0 сем' заботиться, думая, что ежели мнъ̆ что слььдуетъ, то и безъ того получу, а просить о себъ почиталь низостью.

ғнязя Репнина, что онъ безъ него по извйстной его осторожнности въ крбъпкой непріятельской позиціи атаковать не осмъллится, и что въроятно сталь бы ретпроваться; тогда Кутузовъ взошель бы на гору, ударилъ бы непріятелю во Флангъ и одинъ разбиль о̆ визиря.

${ }^{173}$ ) Петръ Прогофьевичъ Панкратьевъ, тайный совътникъ и гіевскій губернаторъ, род. 1757 , ум. 19 марта 1810 года. $M . J I$. 
По возвращеніи нашещъ за Дунай, прибыль принцъ Виртембергскій, пеньшой брать тогда бывшей великой княгини Маріи Өедоровны; отъ того ли, что спьшиль и очень обезпокоился, или отъ того, что не успьль пріњхать къ баталіи, онъ огорчился, опасно занешогъ и вскорь умеръ ${ }^{174}$ ).

Визирь, узнавши, что мы опять перешли за Дунай, во3вратился въ прежній свой лагерь подъ Мачинъ. Турецкая Флотилія приблизилась было къ нашей. Де-Рибасъ послалъ къ начальнику оной сказать, чтобъ онъ тотъ же часъ отошелъ назадъ, или онъ его къ тому принудитъ. Паша виъсто отвъта прислаль къ нему нъсколько арбузовъ и кусоћъ льду. Де-Рибасъ тотчасъ подаль сигналъ сняться съ якоря, построиться въ боевой порядокъ и выступить. Однакожь паша, не взирая на гордый, затъйливый отвътъ, не дождался приближенія нашей флотиліи и отплыль къ Браилову. Вскорж визирь прислаль къ князю Репнину, съ предложеніемь открыть переговоры 0 мирь. Князь быль уполномоченъ оть императрицы, почему, ни мало не медля, повъренные съ объихъ сторонъ въ Галацахъ съъхались, сдйыаны были предварительныя условія и подписаны визиремъ и княземъ Репнинымъ; для утвержденія ихъ назначенъ конгрессъ въ Яссахъ.

Свъьтыйишій князь прівхалъ посль сего черезъ три дня, и очень ему было досадно, что князь Репнинъ поспьшилъ заключить миръ; онъ выговариваль ему при многихъ, сказавъ: «Вамъ должно было бы узнать, въ гақомъ положеніи напъ Черноморскій флотъ, и о экспедиціи генерала Гудовича; дождавшись донесенія ихъ, и узнавъ отъ оныхь, что вице-адмираль Ушаковъ равбиль непріятельскій флотъ, и

174) Въ сіе время извйстились, что нашъ посолт Я. И. Булгаковъ освобожденъ изъ Семи-башеннаго замка, по просьбъ французскаго министра; но Булгаковъ не иначе хоть̆лъ своего освобожденія, какъ по уваженію къ Россійскому двору, на что Порта принуждена была согласиться. 
уже его выстрбыл были слышны въ самомъ Константинополь, а генераль Гудовичъ взль Апапу, тогда бы вы могли сдъ̌лать несравненно выгоднъййя условія ). Это дъйствительно было справедливо. Хотя князь Репнинъ слыль за государственнаго человъ̌ка и любящаго свое отечество, но въ семъ случағ предпочель личное свое любочестіе пользъ государственной, не имъъъ иной побудительной причины поспёшить ваключить миръ, кронь того, чтобъ его

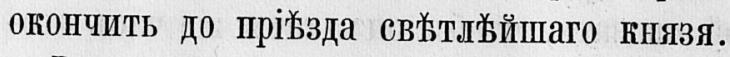

Въ то время принщъ Виртембергскій умеръ; свъ̌тльйшій князь былъ на похоронахъ, п, какъ по огончаніи отпхьванія князь вышелъ изъ церкви, и приказано было подать его карету, вщъстто того подвезли гробовыя дроги; князь съ ужасомъ отступилъ: онъ былъ чрезвычайно мнителенъ. Послт̈ сего онъ вскоръ занемогъ, и повезли его больнаго въ Яссы.

Армія для лучшаго продовольствія раздъ̌ыена была на небольшіе лагери; нашему полку назначено было стоять вмьст宂 съ Екатеринославскищъ и Московскимь гренадерскиюъ при Рябой Могиль. Тамъ получили повельнніе, что всъ сіи три полюа составляютъ одинъ 10-й баталііонный полкъ подъ названіеиъ Екатеринославскаго; четыре кирасирскіе полка составляютъ одинъ полюъ подъ названіемъ тейбъ-кирасирскаго; изъ 3000 казаковъ Донскаго войска составленъ одинъ полкъ подъ названіемъ Великой Гетманской Булавы. По тогдашнешу положенію, въ каждомъ батальонь было по два орудія артиллеріи, въ мушкетерскихъ полкахъ трехъФунтовыя пушки, въ гренадерскихъ осьми-фунтовые единороги; въ бывшемъ же Екатеринославскомъ полку были двънадцати-фунтовые единороги. Итаюъ, полюъ сей, будучи въ комплекть, состоядъ изъ 11,000 человььь и 20 орудій артиллеріи; присоединя къ оному кирасирскій 24-хъ эскадронный полкъ и полкъ Великой Булавы, все вмъстьъ составляло значительный корпусъ. На сей счетъ разныя дызлали 
догадки; прямой цъљли никто не постигалъ, ибо не возшожно был0, чтобъ одинъ тодько капризъ князя Потемкина былъ тому причиною. Одни полагали, что онъ хоть̌ль быть господарещъ Молдавіи и Валахіи; другіе-что онъ хотьыль себя объявить независимымъ гетманомъ; иные думали, что онъ хотьыъ быть королемъ Польскимъ; а болье всего полагать должно было, что по окончаніи войны онъ потребуетъ отъ Польши пройдти чрезъ оную только тремъ полкамъ, готорые бы составляли авангардъ арміи, дабы разрушить сдъзланную въ Полышъ конституцію, наказать ее за сдъъланное неудовольствіе русскому послу, господину Штакельбергу, и за т0, что принудили изъ Полыши вывести наши магазины и охраняющія оные войска. Поводомъ къ оному мнгьнію служить, что свъ̌тљьйшій князь послал'ь подполюовника Бакунина въ Венну къ удалившимся туда польскимъ вельможаиъ, недоводьнымъ тою конституціею; по приглашенію его прибыли въ Ассы знатнъйшіе паны, кағъ-т0: гетманъ Браницкій (съ его супругою, племянницею князя Потемкина), Ржевускій и многіе другіе; тамъ сдълано было положеніе Тарговицкой конфедераціи подъ погровительствомъ Россіи.

Боль̌знь свъ̌тыъйшаго князя стала усиливаться, но онъ не хотьљь прининать никакихъ лькарств'ь, вопреги медиковъ Тимона и Массота; и, будучи въ жару, мочиль себъ голову холодною водою ${ }^{175}$ ).

173) Св Һัтлњйшій князь, будучи въ Петербургъ, далъ въ присутствіи императрицы великольпный праздникъ въ Таврическомъ своемъ домь, который послго его смерти взятъ въ казну и названъ Таврическимъ цворцомъ. Очаровательный сей праздникъ описанъ нашимъ славнымъ поэтомь Гавріиломь Романовичемъ Державинымъ. Наконецъ ивдерживаемыя имь суммы и роскошная его жизнь привели императрицу в'ь неудовольствіе; къ тому же Зубовъ такъ усилился, что началь съ нимъ совмьсстничать; наконецъ государыня потребовала, чтобы князь ьхаль въ армію, чего онъ такъ скоро исполнить не желаль; приближеннымъ 
Генераль М. $\theta$. Каменскій, видя, что его на службу не требуютъ, прізххавъ въ Петербургъ, просилъ императрицу 0 повволеніи ьхать въ армію, для свиданія съ своимъ сынощъ, служившимъ тогда подполковникомъ въ Московскомъ полгу, котораго самъ онъ быль шефомъ. Государыня ему сказала: «Это отъ васъ зависитъъ. К Каменскій, пріихавъ въ Яссы, чрезъ нёскольго дней, просиль свб̈тл'ъйшаго князя позволить ему ъхать спотрйть свой полкъ; гнязь его удержаль одинъ день, но въ самое то время, не сказавъ ему ни слова, послаль курьера, съ приказаніемъ́ о спормированіи большаго Екатеринославскаго полка, гағъ было сказано. Каменскій прівзтаетъ въ Јагерь подъ Рябую-Могилу, но полкъ его Московскій не существуетъ. Все сіе служить доказательствомъ, чтө служба его императрицъ была не угодна, и какое неуваженіе имь̆ыъ къ нему свйтльййій князь.

Въ исходъ́ августа армія встушила въ зимовыя ввартиры. 4-хъ батальоннаго стараго Екатеринославскаго полға штабесъ-квартира расположена была въ Яссахъ, а вновь присоединенныхъ 6 батальоновъ-въ Ботушанахъ. Отъ новаго моего полковника Булгағова, при оныхъ батальонахъ опредъиленъ я быль преміеръ-майорощъ и для продовольствія своего полка артилерійскихъ и подъемныхъ лошадей, которыхъ было больве тысячи; хотя и были при оныхъ батальонахъ два подполговника Мягкой и С. М. Каменскій ${ }^{176}$ ),

своимъ тогда онъ говаривалъ: «Зубъ болитъ; надобно его сперва выдернуть). Думать надобно, что сіе была истинная причина его болґзни, и напрасно думали, что ему былъ данъ ядъ: для честолгобиваго человъка и то настоящая отрава. Замьттли, что въ пути своенъ въ армію сталъ онъ задумчивъ и временами жаловался на боль головы.

(Праздникъ этоть быль данъ 28 апрьля 1791).

176) Графь Сергйй Михайловичь Каменскій, генераль отъ инфантеріи, род. 3 іюня 1772, ум. 8 декабря 1834 г.; онъ родоначальникъ нынъ̆шнихъ графов'ь Каменскихъ. Меньшой брать его, графъ Николай 
но они въ командованіе полка и мои распоряженія не вмъшивались.

Въ сентябрь прибыли полномочные турецкіе министры трактовать о мирь; но открытіе конгресса отложено было до октября. Нашими министрами назначены были: генеральпоручикъ Самойловъ, генераль-майоръ де-Рибасъ и бригадиръ Лашкаревъ.

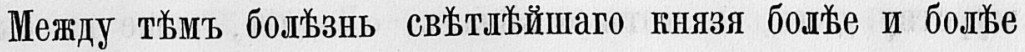
усиливалась; чувствуя изнуреніе своихъ силъ, онъ послалъ курьера съ повельніемъ къ командующему войсками въ Крыму, генералу Каховскому ${ }^{177}$ ), чтобъ онъ прибылъ принять въ завьдываніе его армію, во время его отлучки, намъреваясь отъьхать въ Николаевъ. Пятаго октября, въ сопровожденіи графини Браницкой, отправился онъ въ путь. Пробхавъ отъ Яссъ 30 версть, князь почувствовалъ приближеніе смерти, вельль остановиться и вынесть себя изъ кареты; легъ на разостланный на дорогъ плащъ и въ объятіяхъ своей любимой племянницы графини Браницгой испустиль духъ. Тъло его перевезли въ Херсонъ.

Ћабинетъ-сегретарь императрицы генераль-майорь Василій Степеновичъ Поповъ, управлявшій всьми дъълами при свьтллйшемъ князь, пріххавъ въ Яссы, явился у Каменскаго, объявиль ему о смерти главнокомандующаго, какъ старшему, или лучше сказать одному и бывшему тогда генералъ-аншефу, и требовалъ, отъ него приказанія. Каменскій, Удивясь скорой кончинь свьттљйшаго князя, потребоваль тотчасъ отъ Попова отчета въ дълахъ и эюстраординарныхъ суммахъ. Тоть отвъ̌чалъ, что онъ кабинетъсекретарь ея величества и быль не при арміи, а един-

Михайловичъ, знаменитый полководецъ, ум. 4 мая 1811 г. генераломъ отъ инфантеріи и гавалеромъ св. Андрея и св. Георгія 2 класса, имья не болье 34 лььть отъ роду. Онъ род. 27 декабря 1776 года. М. Л.

177) Графъ Михаиль Васильевичъ Каховскій, генералъ отъ инфантеріи, род. 1734 , ум. 1800 года. М. Л. 
ственно при особъ свъ̆тльйшаго внязя, почему отчета никакого и дать не можеть.

Каменскій вышель изъ себя, побъжаль къ дежурному генералу В. В. Энгельгардту, страдавшему тогда злою лихорадкою, и смертью дяди и благодъ̆теля своего сраженному. Въ той же гощнатъ̌ лежала въ бевпамятствъ сестра его графиня Браницкая. Каменскій требоваль отъ него по дежурству дҺъљ, но тоть отвъัчалъ: «Видите, ваше высокопревосходительство, въ кағомъ я положеніи, и прикажите явиться къ себॐ при дежурствъ находящимся штабъ-оФицерамъ: я не въ силахъ головы поднять». Каменскій бросился въ дежурство, билъ всякаго, ћто съ нимъ только встржчался: солдатъ, Молдаванъ и Жидовъ, какъ будто сумасшедшій. Онъ отдаль приказъ по арміи, что вступаетъ въ гомандованіе оною, и тотчасъ отправилъ въ Ботушаны курьера за сыномъ, чтобъ послать его къ императрицъ съ извъстіемъ о смерти свьтлььйшаго княвя. Но Поповъ отправидъ о томъ того же дня отъ себя донесеніе ${ }^{173}$ ).

Какъ всъ генералы тогда были въ Яссахъ, не имъя никакого начальства, а полкапи распоряжалось главное дежурство, то Каменскій потребоваль, чтобы генералы дали 0

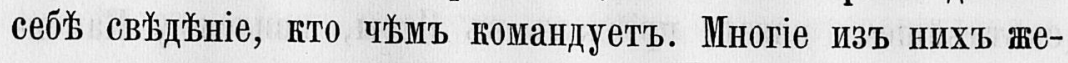
лали имьть его начальникомъ, полагая, что Каховскій не имьль большихъ дарованій, и т年 другіе, зная его нравъ, предпочитали болье Каховскаго; ть отозвались подъ разными предлогами, что не состоять при арміи; какъ-то Самойловъ и де-Рибасъ объявили, что они при конгрессъ, а многіе нашли другія отговорки.

Посль смерти свътлыьйшаго князя, чрезъ два дня пріьхалъ и Каховскій, и отдаль приказъ, что по ордеру покой-

178) Каменскаго сынъ чрезъ сутки явился къ отцу; за медленное его прибытіе онъ при всьхх даль сыну двадцать ударовъ арапникомъ и съ таковымъ пашпортомь его отправиль. 
наго главнокомандующаго вступаетъ въ командованіе арміей. Тутъ началась у нихъ съ Каменскимъ брань: оба дълали приказанія и распоряженія, противныя одно другому.

Каменскій, видя, что большею частію склонялись болье къ Ћаховскому, созваль на совътть всъхъ генераловъ и предложилъ имъ: кому изъ нихъ двухъ командовать арміею? Артиллеріи генералъ-майоръ И. М. Толстой ${ }^{179}$ ) сказалъ: «Ежели бы они знали, что они созваны для избранія себъ гомандира, то конечно бы изъ нихъ никто не прізхалъ; ибо при самодержавномъ правительствъ должно повиноваться властямъ, поставленнымъ отъ императрицы, а не выбирать себъ начальника». Князь Г. С. Волғонскій сказалъ:

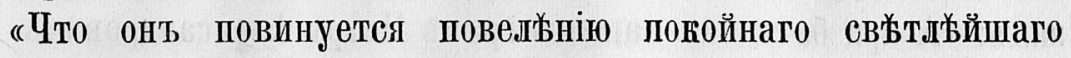
князя, Ћоторому извъстна была воля государыни, ибо какъ ваше высокопревосходительство были лично въ Яссахъ, то князь и могъ бы поручить вамъ гомандованіе арміею, и не было надобности для того посылать за М. В. Каховскимъ». Веґ почти приняли сторону Волконскаго. «И такъ, сказаль Ћаменскій, вы отрекаетесь мнъ повиноваться,быть піо семуу.

Посль сего Каховскій уже безспорно сдъзался главнокомандующимъ. Ежели бы Каменскій обошелся хорошо съ Поповымъ, то навърно бы остался гомандиромъ арміи.

Между тьъъ приготовляли похороны свътлыйшему князю. Я. потребованъ быль для оной церемоніи. Проъзжая квартиры стараго Екатеринославскаго полка, за'ьхаль на квартиру унтеръ-офицера, чтобъ онъ нарядиль мнъ двъ перемъны лошадей. $\mathscr{A}$ нашель у него нъсколььо старыхъ гренадеръ, готорые хотьли-было выйдти; я ихъ остановилъ и началъ съ ними разговаривать. Между прочииъ я спросилъ: “Скажите, ребята, вы были 3-го гренадерскаго полка, всегда были при главной квартирґ славнаго нашего фельдмаршала

179) См. выше, примъчq. 118-е́. 
Румянцова и были его любимынъ полкомъ; потомъ также быль полкъ сей всегда при погойнонъ свйтльйшешь князъ и также его любимымъ полкомъ, въ которомъ онъ быль и шефъ; одинъ изъ нихъ уже умеръ, а другой такъ старъ, что конечно никогда уже не будеть командовать арміею; гого изъ нихъ вы болье любили?» Одинъ гренадеръ отвъччалъ: “Покойный его свйтлсть былъ намъ отецъ, облегчиль нашу службу, довольствоваль насъ всъии потребностями; словомъ сказать, иы были избалованныя его дььти; не будемъ уже мы имъ̌ть подобнаго ему командира; дай Богъ ему въчную память!» Тутъ онъ прослевился и отеръ свои глаза; но вдругъ глаза его оживились, онъ пріосамился и ска-

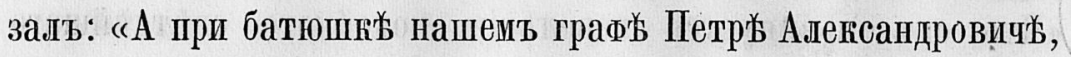
хотя и жутко намъ было, но служба веселая; молодецъ онъ былъ, и какъ онъ бывало взглянетъ, то какъ рублеиъ подарить, и оживляль насъ особымъ духонъ храбрости».

Погребеніе тъ̌ла князя происходило 13 октября сльвдующимъ порядкомъ. По совершеніи духовныхъ обрядовъ, приготовлена была пространная зала, гдъ долженствовало быть поставлено тъ̌̆ло усопшаго, вся обитая чернымъ крепомъ съ Флеровыми перевязями по бортаиъ.

Влереди для ғатафалка сдъ̌лано отдызленіе шелковою черною занавъьсою, обложенною по бортамъ серебрянымъ позументомъ, съ большими по срединъ висящими серебряными кистями и подтянутою серебрянымъ шннркомъ; нъъсколько подалъе поставлена была балюстрада, обитая черныщъ сукномъ и обложенная сверху по краямъ широкимъ серебрянымъ позументомъ.

Потологъ сего отдъъленія одъъть былъ наподобіе павильона - чернышъ сукномъ и увить крестообразно по краямъ бълыми и креповыми перевязями.

По срединъ отдъзленія поставленъ былъ амвонъ, обитый краснымъ сукномъ, съ тремя ступенями, обложенными по краямь серебрянымъ позументомъ. 


\section{$-131-$}

На срединь амвона сдъълано было возвышеніе, покрытое богатою парчею, на коемъ поставленъ быль гробъ, обитый розовымъ бархатомъ, выложенный богатымъ золотымъ позументом'ь, съ серебряными скобами на серебряныхъ подножіяхъ и покрытый богатымъ парчевымъ покрываломъ.

Надъ гробомь сдъзланъ быль великольвпый балдахинъ изъ рововаго бархата, обложенный по краямъ чернымъ бархатомъ, съ богатымъ золотымъ позументомъ. Спуски онаго были изъ розоваго бархата, обложенные золотымъ позументомъ съ бахрамою и поднятые шнурами съ небольшими золотыми кистями. Балдахинъ поставленъ былъ на 10 древкахъ, обтянутыхъ розовымъ бархатомъ и перевитыхъ серебрянымъ позументомъ, и укрйленъ къ землъ восемью золотыми шнурами, на коихъ повйшены большія золотыя кисти. На верху балдахина, по углащъ и по срединъ, укрььплены страусовыя черныя и былыя перь; внутри оный былъ обложенъ бълымъ атласомъ.

Въ головахъ, на сдйланномъ воввышеніи, положена была на парчевой вољотой подушкъ княжеская юорона, обведенная лаврами.

На первыхъ отъ гроба ступеняхъ, у головы съ объихъ сторонъ стояли табуреты, покрытые граснымъ сукнонъ съ золотымъ по краямъ позументомъ, на коихъ положены были подушки изъ малиноваго бархата, обложенные золотымъ позументомъ съ бахрамою и съ золотыми по угламъ висящими кистями; на оныхъ съ правой стороны положенъ Фельдмаршальскій жезлъ, а съ льъвой въннецъ лавровый ${ }^{180}$ ); съ сей же стороны, пониже, лежала крышка отъ гроба, на коей находились шпага, шляпа и шарфъ. На посльъдней ступени расположены были на таковыхъ же бархатныхъ

${ }^{180}$ ) Екатерина пожаловала этотъ въ̌нокъ Потемкину по окончаніи гампаніи 1789 г. ВЪ̈нокъ этоть былъ золотой и усыпанный изумрудами и брилліантами и стоилъ 150,000 рублей. $M$. $I$. 
подушкахъ всъ ордена покойника по старшинству ихъ, всь знаки власти, полученные имъ въ награжденіе заслугъ оть милостей монаршихъ.

По сторонамъ катафалка поставлены были двъь пирамиды изъ бълаго атласа, увъшанныя чернаго и бълаго крепа перевязями. На пирамидъ, стоявшей съ правой стороны, виденъ быль гербъ его свътлости, по сторонамъ поставлены два знамени великаго гетмана, а на черной доске́ изображена была бълыми буквами сльдующая надпись:

«Въ Бозь почивающій свьттльйшій князь Григорій Александровичъ Потемкинъ-Таврическій и проч. и проч., усердньйшій сынъ отечества, присоединитель къ Россійской имперіи Һрыма, Тамани, Ћубани, основатель и соорудитель побъдоносныхъ Флотовъ на южныхъ моряхъ; побъдитель силь турецкихь на сушь и поръ, завоеватель Бессарабіи, 0чакова, Бендерь, Аккермана, Ћиліи, Измаила, Анапы, Сучукъ-Кале, Сунніи, Тульчи, Исакчи, острова Березанскаго, Хаджибея ${ }^{181}$ ) и Паланки; прославившій оружіе Россійской имперіи въ Европь и Авіи, приведшій въ трепеть столицу и потрясшій сердце Оттоманской имперіи побьдами на моряхъ и положившій основаніе къ преславному миру съ оною; основатель и соорудитель многихъ градовъ; покровитель наукъ, художествъ и торговли; мужъ, украшенный всьми добродътелями общественными и благочестіемъ. Скончаль преславное теченіе жизни своей въ княжествь Молдавскомь, въ 34 верстахъ оть столичнаго города Яссь, 1791 года октября въ 丂̆-й день, на 丂2 году оть рожденія, повергнувъ въ бездну горести не только облагодьтельствованныхъ, но и едва в'цдающихъ его».

На пирамидъ, съ льъой стороны стоявшей, виденъ быль гербъ во всемь подобный первому, а по сторонам'ь поставлены были: справа-кейзеръ-флагъ, а сльва - гетманское знамя.

181) Одесса. 
Девятнадцать большихъ свъ̌чъ, въ высокихъ подсвъัчникахъ, обложенныхъ золотою парчею, и множество меньшиихъ свъът, поставленныхъ кругощъ гроба, освъъщая гатафалгъ, представляли весьма важное и великольпное зрълище, внушающее благоговъніе и горесть. 11-го числа, по совершеніи всъхх вышеписанныхъ приготовленій, тйло поставлено было на катафалкъ и учреждено при гробъ дежурство изъ одного генералъ-майора, двухъ полковниковъ, четырехъ штабъ-ошицеровъ, и восьми оберъ-опицеров'ъ, одного генеральсъ-адьютанта и одного флигель-адъютанта. Тогда объявлено было въ городъ, что хотящіе отдать посльдній долгъ погойному фельдмаршалу допускаемы будуть къ тому безъ ивъятія.

Народъ стекался толпами; горесть написана была на всйхх лицах'ь, наипаче воины и Молдавскіе бояре проливали слезы o потеръ своего благодьт теля и друга; въ сіе время поставленный у дверей офицеръ раздаваль убогииъ мелгія серебряныя деньги. Поклоненіе тйлу происходило сего числа пополудни отъ 3 до 6 часовъ. Въ часы прихода для покло-

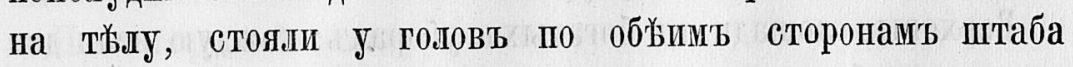
покойнаго фельдиаршала два генеральсь-адъютанта, у средины гроба по два гвардіи офицера, два флигель-адъютанта, а нъсколько подалье по два офицера Екатеринославскаго гренадерскаго полка; внутри съ правой стороны лейбъгвардіи отъ бомбандирской роты, съ ль̌вой кирасирскаго полка княвя Потемкина, а у балюстрада того же полка по два офицера въ супервестахъ.

12-го числа двери отворены были отъ 10 часовъ пополуночи до 2-хъ часовъ пополудни, потомъ отъ 3 -хъ до 8 часовъ вечера, въ поторое вреия по прежнему была раздача убогимъ серебряныхъ мелкихъ денегъ. Между тъим одинъ генеральсъ-адыютантъ, два флигель-адъютанта на лошадях'ь, въ сопровожденіи одного эскадрона полка княвя Потемкина, въ траурномъ вид官 съ литаврами, покрытыми чернымъ 
сукномъ, возвъстили городу о времени выноса тьљла, которое имйло быть на другой день въ 8 часовъ пополуночи.

13-го числа полки Екатеринославскій и Малороссійскій гренадерскіе и Днжпровскій мушкатерскій стали по обжимъ сторонамъ улицт, гдъ долженствовало пропсходить шествіе. Ћогда духовенство собралось, и все было готово, время выноса возвъъено было 11-ю пушечными выстрблами и унылымъ колокольнымъ звономъ; пальба продолжалась чрезъ каждую минуту до сапаго внесенія тыла въ монастырь Голлій, назначенный къ совершенію сего печальнаго обряда.

Тъљло выносили изъ особливаго усердія генералы, тағже шाтать его свътлости и назначенные къ тому штабъ-опицеры; балдахинъ несли гвардейскіе офицеры, кисти поддерживали полюовники.

ІІІествіе происходило сль̈дующимъ порядкомъ:

Открывалъ оное эскадронъ конвойныхъ гусаръ покойнаго пельдмаршала.

Ва нимъ кирасирскій полкъ князя Потемкина.

Домъ покойнаго въ трауръ.

Верховыя лошади въ богатыхъ уборахъ; каждую вели два конюха въ богатой ливреъ, въ черныхъ эпанчахъ и шляпахъ.

120 человъъъ солдатъ съ факелами, въ черныхъ эпанчахъ

и въ распущенныхъ пляпахъ, съ чернымъ флеронъ.

24 оберъ-офицера въ траурномъ видъ̌ со свйчами.

12 штабъ-оФицеровъ въ траурном ь видъ̌ со свйчами.

Бояре княжества Молдавскаго, князья и посланники Черкесскіе.

За симъ долженъ быль сльъдовать генералитеть; но генералы, какъ выше сказано, выносили гробъ и шли подль онаго до самой церкви.

Духовенство.

Знаки отличія, изъ которыхъ каждый несли штабъ-0Фицеры, имъя двухъ оберъ-офицеровъ ассистентами:

1. Орденъ Св. Андрея. 2. Орденъ Св. Александра Нев- 
скаго. 3. Орденъ Св. Георгія 1-го класса. 4. Орденъ Св. Владиміра 1-го класса. ๖. Орденъ Бълаго Орла. 6. Орденъ Св. Станислава. 7. Орденъ Прусскаго Чернаго Орла. 8. 0pденъ Датскаго Слона. 9. Орденъ Шведскаго Серафима. 10. Орденъ Св. Анны. 11. Камергерскій ключъ. 12. Гетманская булава. 13. Гетманская сабля. 14. Ж⿱㇒ллованная шпага. 15. ВЪнецъ. 16. Бантъ отъ портрета императрицы. 17. Фельдмаршальскій жезлъ. 18. Гетманское знамя. 19. Кейзеръ-флагъ. 20. Другое знамя. 21. Княжеская корона.

Гробъ на черныхъ дрогахъ, запряженныхъ 8-ю лошадьми въ черныхъ попонахъ, изъ которыхъ каждую вель одинъ конюхъ въ черной эпанчъ и шляпґъ.

Парадная карета, полрытая чернымъ сукночъ, запряженная 8-г лошадьии, подъ черными покрывалами; при ней конюхи въ парадной ливреъ и черныхъ эпанчахъ.

За гробомъ шли родственники князя.

Шествіе замыкали: эскадронъ конвойныхъ гусаръ, казачій полкъ Булавы великаго гетиана, Донской казачій полкъ князя Потемкина.

По соверпеніи литургіи преосвященный епископъ Херсонскій Амвросій ${ }^{182}$ ) вышель было сказать надгробное слово, но за рыданіемъ не могъ выговорить ни слова и вошель обратно в' алтарь. По окончаніи отпъванія, когда запъыли въччіую память, сдљ̌лано был0 11 пушечныхъ выстръъловъ, а войско произвело троекратно ружейный беггый огонь. Рыданіе родственниковъ, ближнихъ и воиновъ раздалось со вељхъ сторонъ.

Тьыло омыто горячими слезами облагодъттельствованныхъ покойниюомъ $\left.{ }^{183}\right)$.

182) Апвросій Серебренниковъ, архіепископъ Екатеринославскій и мъ̌стоблюститель эгзархіи Молдо-влахійской, ум. 13 сентября 1792 г. Надгробное слово его Потешкину, о которомт здъ̌сь говорится, было напечатано въ 1791 въ Яссахъ й въ 1792 въ Мосввъ. M. JI.

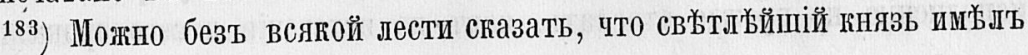


По окончаніи всего, опредъълены были при гробъ къ дежурству одинъ адъютантъ, четыре офицера и караулъ.

Сиерть свйтыъйшаго княвя дала новый ходъ политическимъ сношеніямь между Петербургошь и Константинополемъ. Графь Безбородко прибыль способствовать къ скоруйшему окончанію мирныхъ переговоровь. Долго турецкіе министры не соглашались на требованіе Россіи о вознагражденіи 24 милліоновъ піастровъ; но когда объявили имъ, что ежели они на сію статью не согласятся, то и ғ0нгрессь разрушень, то они и подписали. Въ ту иинуту Безбородко вошель и сіе положеніе разорваль, сказавъ: «Государыня императрица не имъеть нужды в'ь турецкихь деньгахъ». Таковой поступокъ изумиль Мусульнанъ. “Cie великодушіе, воскликнуль рейсъ-эфенди, спасаеть жизнь верховнаго вивиря.» Мирь нежду Россіею и Портою под-

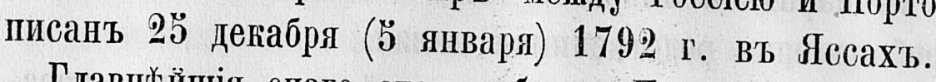

Главнъйшія онаго статьи были: Порта признаеть острова Крымъ и Тамань россійскимь стяжаніемь; ръка Днъстрь составляетъ границу между об̆ъими пмперіями; флоты россійскій парусный и гребной должны оставить владънія турецкія, каґъ скоро получать повельніе, и не позже трехь недызыь посль подписанія мира. Войска сухопутныя оставятъ занятыя владжнія турецкія въ маъ, возвратя завоеванныя крьпости въ такомъ подоженіи, въ кақовомъ оныя при подписаніи мира состоять.

исполненную доброты душу. Во все время его безпримъ̆рнаго могущества ни одного человььа не сдъ̌лаль несчастнымъ. Много было примъировъ, гдъ онъ огазалъ сострадательное сердце, напримъръ: поручикъ артиллеріи баронъ Плото посланъ быль въ Воронежъ дла покупки подъ артиллерію лошадей; онъ всю сумму, данную ему для сей казенной надобности, проигралъ, почеему военнымъ судомъ приговоренъ былъ къ разжалованію навсегда въ солдаты. Когда же поднесена была князю на подписаніе конфирмація, онъ написалъ: «разжаловать въ солдаты на три м⿻есяца со дня подписанія), но Попову приғазалъ къ исполненіго не прежде отослать, как'ь по истеченіи и сего срока. 


\section{v. ШІольская Война.}

1792. Вскорж по об̆ъявленіи и торжествъ мира взяль я отпускъ и отправился въ Ногилевскую губернію къ отцу моему, получившену отставғу, прп чещъ пожаловано было ему по смерть восеньсоть душъ въ Бљлоруссіи, куда онъ на житье и перевхаль.

0тецъ мой меня встрътиль нъготорымъ для меня прискоронымъ выговоромъ: “Хорошо ты пишешь реляціи (ибо я ему писалъ 0 пронсшедшемъ со иною въ Мачинсгой баталіи). Но въ реляціи, припечатанной въ газетахъ, того нь̌тъ; каждый кт0 отличился, всяғій именованъ, но ты съ прочими помыщенъ въ списпь, что быль прищърощъ храбрости и мужества; рекомендованные награждены орденами, золотыми шшагами съ надписью: за храбрость, а тебь съ прочими назначенъ одобрительный листь за подписаніемъ князя Н. В. Репнина.) Больно мнъ было услышать так0-

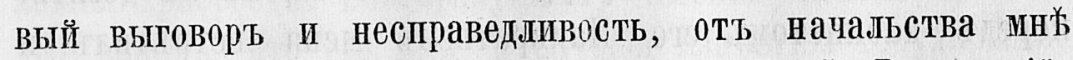
оказанную; но къ счастію поену, князь Г. С. Волконскій, лрп отъъздъъ моемъ въ отпускъ, какъ онъ быль корпусный мой командиръ, далъ мнъ аттестатъ, съ прописаніемъ всего, до меня касающаго во время Мачинской баталіи. Показавъ оный отцу моему, я достаточно его удостовъуриль, что писаль я неложно и не быль самохваль.

Полкъ десяти-батальонный Екатеринославскій былъ раскасированъ и остался по прежнену изъ четырехъ батальоновъ, какь и всь прочіе гренадерскіе полки; офицеров' и нижнихъ чиновъ размьсстили по другичь полкамъ, а штабъофицерамъ вельнно прислать въ военную коллегію прошенія 0 томъ, кт0 в'ь каюой полкъ пожелаетъ быть пом'ъщенъ. Для чего я и отправился въ С.-Петербургъ, и такъ какъ князь Репнинъ былъ тамъ, то и хоть⿻ы'ъ просить его утвердить своимъ подписомъ аттестатъ, данный мнъ кня- 


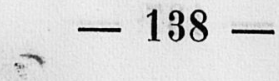

вемъ Волконскимъ, по которому могъ бы я требовать награжденія.

Прибывъ въ С.-Петербургъ, увидъълся я съ служившимъ тогда при банкъ И. С. Захаровымь ${ }^{184}$ ), по сосъдству деревень отца моего сдёлавшимся ему короткимъ знакомымъ. Когда сказаль я ему о причинё моего прізъзда, то онъ говориль мнъ, что онъ хорошій пріятель Панғратьеву, управлявпему ганцеляріею гнязя Репнина, и просиль ввърить ему мой аттестать для показанія и требованія отъ него совьта, какъ съ нимъ поступить. Я не разчель, что Пангратьевъ, писавъ реляцію, не захочетъ признать свою ошибку, и аттестать Захарову отдалъ.

На другой день пріњхалъ я къ Захарову, готорый мнъ сказаль, что Панкратьевъ удивляется аттестату, данному мнъ̌ княземъ Волконскимъ, ибо-де онъ меня не рекомендовалъ. Несмотря на то, ръишился я бехать къ князю Репнину и съ самимъ имъ объясниться, что́ на другой день и исполниль. Прівхалъ я поутру къ князю часовъ в'ь десять; передъ кабинетомъ его Панкратьевъ меня встрбтиль и спросиль, что мнъь угодно. Я сказаль ему о моей претенціи; но онъ, каюь и Захарову, говориль мнъ, что княземъ Волюонскимъ я не регомендованъ, и просилъ идти съ нимъ въ канцелярію. Пришедъ туда, показываетъ онь инь рапортъ князя Волконскаго, въ которомъ онъ рекомендоваль лично только при нешъ бывшихъ, но что онъ утверждаеть въ донесеніи справедливую рекомендацію карейныхъ командировъ. Тогда я сказаль: “Посиотрите рапортъ карейнаго моего командира». Въ немъ Пангратьевъ увидъъль, что рекомендація моя во всемъ согласна съ полученнымъ мною аттестатомь. На это Панкратьевъ сказаль, что дызлали представленія къ награжденію только ть̆хъ, кого корпусные

181) Иванъ Семеновичъ Захаровъ, сенаторъ, занимавпійся литературой и членъ Шишковской «Бесъпды люойтелей русскаго слова). М. Л. 


\section{- $139-$}

командиры рекомендовали лично ${ }^{185}$ ). «А затьумь вы получить не можете болье ничего», прибавиль онъ. “Каґъ бы то ни бы.т, сказалъ я, прошу о мнь доложить его сіятельству; по извъстной его справедливости, онъ не откажеть удовлетворить въ моенъ требованіи.)

Піанкратьевъ вошель в'ь кабинеть къ гнязю и, пробывъ тамъ съ четверть часа, позваль меня къ нему. Каґъ скоро я вошель, то князь, не давъ мнъ вымолвить ни слова, сказалъ: «Здравствуйте, мой другъ; это вы, который мною въ Мачинской баталіи посыланы были атаковать гору? Вы то исполнили какъ храбрый оФицерь и добрый слуга ея величества (и выхваляль меня минуть съ пять). Да вы, другъ мой, и награждены». - Ваше сіятельство, я видйль себя въ спискь награжденныхъ одобрительнымъ листомъ. «Какъ, другъ мой, вы этимь недовольны? развъ не все равно, ордена, шпаги?-все то не что иное, какь благоволеніе монаршее, то же что и листы, а вы хотите быть вывъскою вашей храбрости. Благоразумному человьку довольно, когда уже знаетъ, что его пмя и служба извьстны государынь; вамъ болье ничего не надобно, и нбть надобности ни въ какомь аттестать. Простите, мой другъ, я не имтюю болье времени быть съ вами; спьшгу во дворещъ; а когда случай приведеть насъ быть вмьсть্ на ратнощъ польь, зная вашу

18з ) Между неъкоторыми я зам'ьтилъ, что отлично рекомендованъ ротмистръ Хорватъ и награжденъ орденомъ св. Георгія 4-го класса, кот0раго съ двумя әскадронами гнали Турокъ съ двадцать, и что̀ самъ князь Репнинъ видя, сказаль, что ихъ надобно одъть въ съ̌рые кафтаны. Показавъ ему сіе, я сказаль: «Не натурально, чтобы корпусный командирь, будучи занятъ распоряженіемъ, могъ видтть дъйствія всъхъ, а въ п'ххоть невозможно никому особливо отличиться, ибо ивъ фронта выскочить невовможно, разв告 только въ такомь случаб̆,

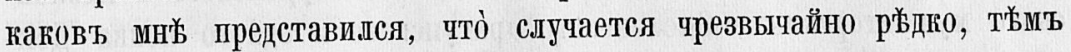
болье, что то было въ глазахъ самого главнокомандующаго». 
способность, мужество и ревность нъ службъ, не премину васъ употребить какъ отличнаго штабъ-оФицера».

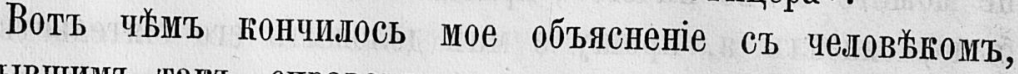
слывшимъ таґъ справедливымъ, какъ древній Аристидъ.

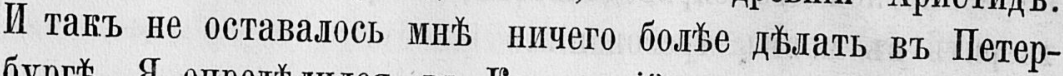

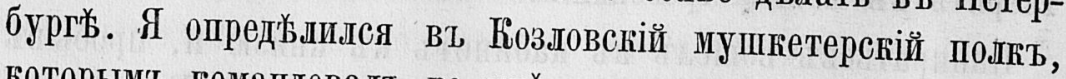
которым'ъ командоваль ко мнъ хоропо расположенный полковникъ И. Н. Рокасовскій, давно просивпій неня перейдти

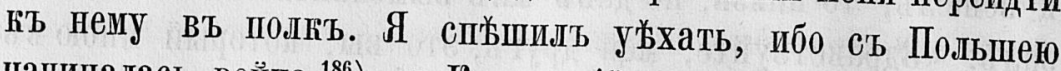
начиналась война ${ }^{186}$ ), и Козловскій полкь уже пошель къ границб въ отрядъ генералъ-поручика графа Мелина.

Возвратясь къ отщу моему, снабдившему меня всъัмъ потребнымъ, отправился я въ полкъ, который уже нашелъ въ Новогрудке Виленской губерніи, и, къ сожальннію моему,

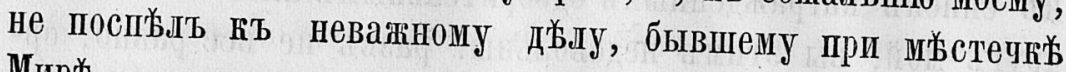
Миръ.

Войска вступили въ Польшу разными отрядами: генералъ-поручикъ Ферзенъ со стороны Рогачева, генералъ-поручикь графъ Мелинъ со стороны Толочина ${ }^{187}$ ). Со стороны Лифляндіи и Полоцкой губерніи вступили два отряда; всъ они были подъ главнымъ начальствомъ М. Н. Кречетникова.

Вся молдавская армія, подъ главнымъ начальствомъ генералъ-аншеса М. В. Каховскаго, переправнсь черезъ Днйстръ въ Могилевъ, вступила въ Польшу; авангардоиъ оной коман-

186) Претекстъ сей войны подали нькоторые польскіе вельможи, недовольные новою конституціей, просившіе императрицу уничтожпть оную, ибо она противна ихъ вольности и прежнимь уставамъ, и потому-что малая только часть ихъ участвовала въ утвержденіи оной. Почему и составили они конФедераціо въ Тарговицахъ.

187) Деташементъ его состояль ивъ полковъ Муропскаго и Козловскаго мушкетерскихъ, Смоленскаго драгунскаго и одного полка Донскихъ козаковъ съ десятыо орудіями артиллеріи. 


\section{$-141-$}

довалъ графъ Ираклій Ив. Марковъ $\left.{ }^{188}\right)$, а подъ нимъ Флигель-адъютантъ императрицы, графъ Валеріанъ Александровичъ Зубовъ $\left.{ }^{189}\right)$. Такимъ образощъ со. всь̌хъ сторонъ ть̌́снили Поляковъ.

Авангардъ молдавской арміи отдъљлился на большое разстояніе отъ главнаго корпуса. Какъ Поляковъ презирали, то сразиться съ ними было единодушное веъхъ рвеніе, ибо думали, чт0 при появленіи нашихъ войскъ они тотчасъ поб̆ъгутъ. Но извъстный польскій генераль Костюшко ${ }^{190}$ ), служшвшій волонтеромъ въ Соединенныхъ Штатахъ Америги, когда они отложились отъ Англіи, былъ мужественъ и опытомъ наученъ въ военномъ пскусствъ. Узнавъ, что русскій авангардъ далеко отдъълился отъ арміи, съ значительными силами остановилея

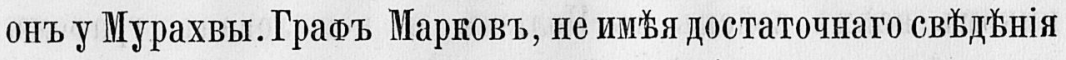
o силь непріятеля, атаковаль его; сраженіе сдъзыалось упорно, и уже наши стали ослабъвать, потеряли много людей и были въ опасности быть разбитыми, какъ, къ счастію, обозъ авангарда сталъ погазываться изъ за горы въ пыли. Костюшко, думая, что то идетъ вся армія, и не бывъ въ силахъ съ оною сразиться, отступилъ. За сію мнимую побъду граФъ Марковъ и всъ съ нимъ бывшіе осыпаны награжденіями, вшъсто того чтобы за самовольное отдаленіе на большое разстояніе отъ арміи (чъмъ подвергали весь авангардъ опасности истребленія) быть отданными подъ военный судъ. Но туть быль братъ фаворита, молодой человъћъ съ пылкииь желаніемъ отличиться: воть и вся побъда! Посль̈днее было

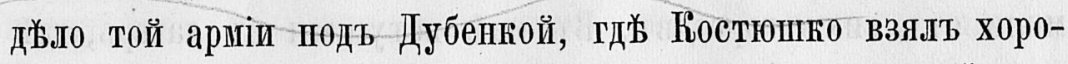
шую позищію между болотистыми дефилеями, укрйпивъ

188) Графъ Ираклій Ивановичъ Марковъ, генералъ отъ инфантеріи, родился 2 нонбря 1753 года, умеръ 26 марта 1829 года. $M$. J.

${ }^{189}$ ) Графъ Валеріанъ Алегсандровичъ Зубовъ, генералъ отъ иншантеріи, род. 28 ноября 1771 г., ум. 21 іюня 1804 г. M. J.

${ }^{190}$ ) Тадеушъ Костюшко, род. 1753 г., ум. $3 / 15$ окт. 1817 г. M. Л. 
оныя Флешами. Поляки защищались храбро; рйшиль дъ̌ыл полковникъ Паленбахъ съ Елисаветградскимъ конно-егерскимъ полкомъ: онъ овладъљъ сими укржнленіями, но самъ быль убитъ. Посльъ сего вся армія безостановочно шла къ Варшавъ. Съ другой стороны графы Мелинъ и Ферзенъ, имъ̌въ небольшое дйыло подъ Мстивовомъ, дошли до Буга, гдъ̌ получили извъстіе отъ Каховскаго, что съ Поляғами война кончилась, и чтобы Кречетниковъ съ своими отрядами остановился. Вскоръ наши войска заняли Варшаву, и гонституція уничтожена.

Дъйствительный статскій совъ̌тникъ Яковъ Ефимовичъ Сиверсъ ${ }^{191}$ ) сдъ̆ланъ чрезвычайнымъ посломъ въ Польшъ на мисто Штапельберга. Каховскій быль оставленъ начальникомъ всбъхъ войскъ въ Польшь и пожалованъ графомъ за успьшное окончаніе сей кампаніи.

Войска заняли всю Польшу и расположились по квартирамъ. Козловскій польь поступиль въ виленскій отрядъ, подъ начальствомъ генералъ-майора Н. Д. Арсеньева ${ }^{192}$ ); зима протекла покойно, хотя Поляки и показывали намь свое недоброжелательство.

1793. Въ 1793 году въ январъ прибыль командовать войсками генераль-аншефъ баронъ Игельстромъ, на мъсто графа Ћаховскаго. Новый нашъ командиръ не оставилъ насъ ни одного мъъсяца на однъхъ квартирахъ: всъ войска ивбили Польшу въ шахматы. Въ апрьыль взяты были контониръквартиры около Варшавы, Гронды и Вильны, не далъе одной мили отъ сихъ городовъ. Въ маъ вступили въ лагерь, гдъ и простояли до іюля, во время потораго близь Варшавы производились маневры.

191) ГраФъ Яковъ Ефимовичъ Сиверсъ, цъйствительный тайный совъттник, род. 1730 г., ум. 1808 г. Любопытныя Записки его изданы теперь в' Германіи. М. Л.

$\left.{ }^{192}\right)$ Никол. Дмитріев. Арсеньевъ, генералъ-майоръ, ум. 1796 г. М. Л. 
На одни изъ маневровъ Игельстромъ пригласиль всьхх дворовъ министровъ, всъхъ знатныхъ чужестранцевъ и польскихъ матнатовъ. Маневры состояли въ сль'дующемъ: артилеріи генералъ-иайоръ Тищевъ съ артилеріею поставленъ быль на горъ, готорую самъ главнокомандующій атаковал'ь съ остальными войсками; Тищевъ по нъкоторомъ времени ретировался; тогда войска заняли его позицію, на которой поставлены были палатки и приготовленъ быль объденный столъ, которымъ Игельстрощь угощаль всъхъ, имъ приглашенныхъ, генераловъ и штабъъ-офицеровъ. Подъ гувертомъ самого хозяина и у многихъ другихъ нашлись стихи сльъдующаго содержанія: «Знаете ли, отчего генераль Игельстронь тағъ весель? 0ттого, что онъ въ своей жизни первую выиграль баталію). (И въ самомъ дйыъ̌, онъ не имъљъ никогда случая не только дать баталію, но и никакого сраженія подъ личнымъ своимъ предводительствомъ). Kaаре онъ ни прилагаль стараніе отыскать сочинителя сего пасквиля, но не могь; сіе показываеть, каґъ онъ всегда быль нелюбимь войскомъ.

При Гроднъ лагерь быль усиленъ, куда и Козловскій полгт быль потребованъ.

Въ Гроднг открыть быль сеймъ. Сиверсъ потребовалъ за понесенные Россіею убытки въ уничтоженіи конституціи, за разрушепіе анархіи, подобной французскимъ якобинамъ, губерніи: Минскую, Подольскую и Волынскую. Долго Поляки сопротивлялись, но когда увидъљли, что ревностнъйшіе изъ ихъ патріотовъ изъ Гродны пропадали, т0 по продолжительномъ преніи согласились сказанный грай уступить императрицъ. Но такъ каґъ въ Гроднъ былъ и прусскій министръ Бухголыъ и дворы наши были въ тъ̌сной связи, то Поляки справедливо опасались, чтобы король Прусскій не сталь требовать нйюоторыхъ областей, смежныхъ съ его кородевствомъ: потому что его министрь Лукезини способствоваль сдъ̌љать имъ конституцію 3-го 
мая ${ }^{\text {993 }}$. По утвержденіи на сеймь, ғакь сказано, уступить край Россіи, тогда же сдъ̌ълали постановленіе, что ежели кт0 предложитъ трактовать съ Пруссіею въ уступкъ земель отъ Польши, того туть же на сеймь изрубить.

Обрядъ сейма такъ происходилъ. Близъ трона, на кот0рощъ король всякое собраніе бываль, вкругъ его сидъли министры, по сторонамъ сенаторы. Вдоль стъны сдъљљаны были мисста амфитеатромь для депутатовь, или, кањъ они

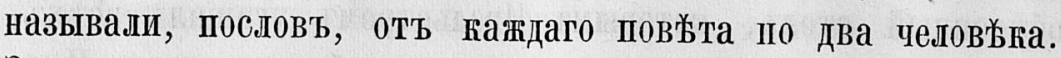
За ними находились зрители, какъ Поляки, такъ и иностранцы, но посльвднимъ не дозволялось быть въ мундирахъ и съ оружіемъ. Избираепь быль сеймовый маршаль, оть котораго зависъуло, если многіе требовали голоса, говорить кому онъ позволитъ. На сей сеймъ былъ выбранъ маршаломъ графъ Бълинскій; собраніе сейма всегда начиналось въ 3 часа по полудни; какъ скоро король садился на тронъ, то сеймовый маршалт объявляль: сесіл залосна, то-есть засьданіе открыто. На что депутаты отвйчали: залосна. Ежели сего не скажутъ, то засъданіе не почиталось открытымъ. Посль сего маршалъ предлагалъ что́ въ прошлошъ сеймъ заслушано и не окончено, или о чемъ сльвдуеть трактовать. Тогда депутаты требовали голоса; сеймовый маршаль говорилъ: ма ллосz по́соль, напримъ̌ръ Слонимскій. Получа позволеніе, тотъ начиналь предлагать въ чешъ имьль нужду. Ежели его голосъ быль принятъ собраніемъ, то всъ закричатъ: слода. И уже то почитано утвержденнымъ и не могло ничъить быть нарушено; если предлагаемое противно, то закричатъ: не позволяль. Ежели же иные кричать: сюда, а другіе: не позволялъ, то собирали голоса подписаніенъ депутатовъ на листь̈ бумаги, который носпли для сего

193) 0динъ монархъ имъ̌лъ требованіе за то, что сдъзлаль конституцію, а другой за то, что разрушилъ ее; п оба правы, по праву сильнаго. 
особо избранные, и тогда ръшалось дъ̌ло по большинству голосовъ. Иногда случалось, что дълали возраженія на произнесенную ръъчь, по дозволенію сеймоваго маршала, и должно сказать, что ораторы объяснялись съ большигъ красноръчіемъ; иные говорили противъ короля въ самыхъ сильныхъ выраженіяхъ, на которыя и король отв'зчалъ всегда съ особливымъ снисхожденіем' и краснортчивымъ убжжденіемъ. Когда же король хотъль говорить, то канцлеръ произносилъ: лснгйиій панъ кроль мовть. Король Станиславь Августь былъ прекрасный мущина, высокаго роста и важной осанки; на сеймж онъ всегда быль въ мундир' народ́́вой навалеріи.

Графъ Бйлинскій быль близорукъ; когда многіе депутаты требовали повволенія говорить, то онъ долго разсиатриваль въ лорнетъ, дабы позволить говорить тому, который согласовался съ интересами дворовъ россійскаго и прусскаго. Случалось, что ошибюою повволял'ь говорить противнымъ псльзамъ оныхъ, и оңи тогда же были выводимы бывшими тутъ русскими оФицерами во Фракахъ, для сего нарочно наряжаемыми. Одинъ закупленный депутатъ Сухуржевскій хотьљљ было предложить трактовать съ прусскимъ министромъ; тогда многіе депутаты, обнаживъ сабли, бросились на него и нанесли ему нъ̌скольљо ударовъ такъ, 'что упомянутые офицеры насилу могли его спасти и вывесть изъ сеймовой залы; а слуги, бывшіе въ съняхъ, кричали: здрайиа (измънникъ), и забросали его шапками.

В0 все время пумливаго сего сейма безпрестанные были праздники, балы, фейерверки; каґъ нашъ посолъ, такъ и прусскій, угощали и веселили Поляковъ, а равно и они угощали Русскихъ. Множество было польскихъ самознатнъйшихъ дамъ, грасотою и любезностію одушевлявшихъ сіи праздники; но грасотою затмъвала всљхъ прочихъ четырнадцатильътняя княжна Четвертинская ${ }^{194}$ ).

194) Которая была посдъ замужемъ за Д. Л. Нарышкинымъ и была 
Нвсколько было засъданій, но трактовать съ прусскимъ министромъ никто болье предлагать не осм'̌⿻丷木ивался. Наґонецъ въ одно таговое засъданіе сеймъ быль окруженъ 4 батальонами съ пушками. Генералъ-майоръ Раутенфельдъ въ мундиръ введенъ былъ въ сеймовую залу; близь трона поставлены ему кресла; сорогъ человььљ офицеровъ въ мундирахъ также введены были въ залу и размжщены въ разныхъ мисстахъ, чтобъ исполнять повель̈нія его превосходительства.

Когда король вошель и съъль на тронъ, то сеймовый маршаль объявиль по обыкновенію: сессія загосна. Не загосна, не загосна, со всъхъ сторонъ раздался грикъ. И сколько разъ маршаль ни начиналь объявлять, то таковымъ же крикомъ отвъ̆тствовали, что̀ происходило до трехъ часовъ утра. Кь дверямъ залы поставленъ быль карауль, чтобы никого не выпускать; кородь изнешогь, и ему приносили ньсколько разъ бульйону и вина. Въ теченіе того времени одинъ изъ депутатовъ сказалъ: “Императрица именуетъ патріотовъ якобинцами; я думаю, что якобинцы противятся законному монархическому правленію и власти королевской, а мы напротивъ защищаеиъ тронъ и права нашего отечества. Но воть ягобинъ (угазавъ на генерала Раутенфельда), который только что не сидитъ на тронт; вотъ якобины, готорые вопреки нашимъ законамъ съ оружіешъ введены въ сеймовую залу для угнґттенія нашихъ правъ; вотъ Якобины, которые стоятъ съ примкнутыми штыками около сейма и поставили пушки, готовыя разрушить тронъ и нашу вольность». По произношеніи сей смълой ръчи, онъ тотчасъ былъ выведенъ. Другой сказалъ: « думаю, что насъ называютъ якобинами потому, что у насъ Россійскій посолъ Якубъ Сиверсъ ). И того вывели.

въ баворъ у императора Александра. JI. Э. Марья Антоновна Нарышкина, ум. 1854 г. 0на была супруга оберъ-егермейстера Дмитрія Јьвовича Нарышвина. $\boldsymbol{M}$. J. 
Наконецъ въ три часа утра, безъ обыкновеннаго предложе̣нія, что сессія заяосна, Бълинскій, подошедъ къ трону, доложиль, что получена оть россійскаго посла нота. Король приказаль ее прочесть. Въ ноть требовӑлось сдъзлать легацію или отдылить нъсколько депутатовъ трактовать съ прусскимъ министромъ. Когда требовалось, чтобы каждый подписаль, согласенъ на то, или нътъ, то никто не осмьливался подать противный голосъ, страшась быть отправленнымъ въ Сибирь. Почему выбраны были уполномоченными тъ̌, готорые уже были напередъ назначены и готовы подписать все, что́ будеть имъ приказано. ТАмт гончилось сіе насильственное засъданіе $\left.{ }^{195}\right)$.

Уполномоченные устушили Пруссіи великое герцогство Повнаньское, что́ утверждено сеймомъ, и сеймъ въ сентяборъ распущенъ. Король и всъ министры возвратились въ Варшаву, а полки вступили въ квартиры. Козловскій полкъ расположилея въ Слоним'ъ.

Іоляки, которые были забираемы на сеймъ, какъ было сказано, и 0 которыхъ думали, что отправлены въ Сибирь, на другой же день по окончаніи сейма явились въ Гродну, гдж они содержались хорошо; но тайно.

1794. Тањь кањъ я сдъълаль нькоторый долгъ, о которомъ нужно мнъ было объяснилься лично съ моимъ отцомъ, т0 ІІ хоть⿻上丨 проситься въ отпускъ; но полковникъ упросил'ь меня остаться до его возвращенія - ибо д'ъла требовали его самаго въ Лифляндію - объщавъ мнъ непремъ̆нно пріъхать въ январъ. Вмъсто того онъ воввратился уже в’ь марть, гогда получено было повельніе ни въ отставку, ни в'ь отпускь не принимать прошеній. Чтобы меня удовлетворить, полковникъ позволиль мнъ сказаться больнымъ и ¿хать въ Могилевскую губернію подъ именемъ капрала Семенова, готораго далъ мнъ въ сопровожденіе, съ тььмъ,

193) Засъданіе это происходило 22 сентября 1793 г. М. Л. 
чтобы я прігхаль передъ выступленіепь въ лагерь, то-есть въ первыхъ числахъ мая.

Во время зимнихъ квартирь видно было броженіе польскихъ Умовъ. Я, будучи въ короткомъ обхожденіи со многими слонимскими жителями и въ окружности города, гдњ квартироваль полкь, видъъъь, что между ними происходили какіе-то непріязненные къ намь замыслы, но не имъъьъ никакого предписанія, оставиль безъ большаго вниманія всь ихъ рбчи, поторыхъ я быль свидътель, почитая ихъ пустымъ самохвальствомъ и думая: ежели бы что между ними затъвалось, то конечно генераль Игельстромъ, сдъљлавшись на мъсто Сиверса чрезвычайнымъ посломъ, былъ бы 0 ихъ расположеніи иввьстенъ и сдйыаль бы по сему случаю начальникамъ войскъ предписаніе. Н0 онъ былъ усыпленъ новою Далилою, его любовницею $\left.{ }^{196}\right)$, графинею Залуцкою, какъ и многіе генералы, подражавшіе въ этомъ главному начальнику. Онъ пренебрегь тогдашнія обстоятельства; а иначе заговорь, Поляками сдъљланный, заранъ̌е быль бы открыть военными чиновниками,, квартировавшими въ Польшь.

Пробывъ у отца моего до 20-то апрьыя, я отправился въь полюь на своихъ лошадяхъ, не имьъя ни мал'йшаго понятія 0 происходившемь въ Польшьљ. Пріжхавъ въ Минскъ и остановясь въ корчщг, пошел'ь я къ вице-губернатору Михайлову, который быль женать на сестръ сверхъ-комплектнаго майора Козловскаго полка Арсеньева. Я увидйль хозяйку и всъхъ, съ нею живущихъ, въ слезахъ; оть нихъ узналь я, что въ Польш`' сдетлалась революція ${ }^{197}$; что въ Вильнъ генералъ-майорь Арсеньевъ захваченъ Поляками въ полонь, чт0 войска наши истреблены, и что Поляки въ большихъ

196) Этою слабою стороною Игельстрома пользовались и въ 0ренбургскомъ краю, гдъ онъ быль намъьстникомъ. См. Записки Д. Б. Мертваго, стр. 39. П. Б.

197) Здъвсь говорится о революціи 6 апрьля 1794 г., подробности поторой разсказываются ниже. $M$. I. 
силахъ идутъ къ Минску. Притощъ я узналъ, что полюовникъ Рокасовскій подалъ просьбу въ отставку, отпущенъ въ отпускъ и проьхалъ уже чрезъ Минскъ, а что польъ Козловскій выступилъ изъ Слонима къ Бресту-Литовскому, п что мнъь въ польъ прожхать никаюъ невозможно: ибо всъхх Русскихъ Поляки на пути рьъжутъ. Чрезвычайное увъ̌домленіе сіе меня изумило и привело въ большое затрудненіе: не бывъ отпущен̆ъ начальствощъ, а только партикулярно полковнигошъ, подвергалъ я себя военному суду, или объявя, тто получилъ отъ полюовника позволеніе, подвергалъ его той же отвъ̌тственности, чҺ̌мъ оказалъ бы ему неблагодарность; почену я ржшился, не смотря ни на какую опасность, Һхать въ полкъ. Едва только возвратилея я въ корчму, гды оставилъ свой экипажъ, кағъ отъ губернатора Н. И. Неплюева ${ }^{198}$ ) ординарецъ пришелъ требовать щеня къ нему, ибо онъ былъ извъ̌щенъ о моемъ пріжздъ̆ отъ г. Михайлова. Нечего было дъълать; я долженъ былъ надызт иундиръ и къ нему явиться. Посль очень въжливаго пріема, Неплюевъ сказалъ: «Я очень радъ вашему прибытію; мое здъъсь самое критическое положеніе: увъдомился я, что Поляки съ нъссколькими войсками и больпимь числомъ посполитаго рушенья идуть къ Минску; здъшніе жители также не надежны. Здъсь оставлено: двъ роты Споленскаго пъхотнаго полка, нъскольюо выздоровъвшихъ изъ гошпиталя, двъ полковыя пушки и пришедшихь три партіи рекруть, каждая по сту человъ̌ьь, но ни одного нуътъ штабъ-обицера; почему извольте принять все то въ свою команду, сдълать свое распоряженіе и изготовиться дъзуать отпоръ). Я ему представилъ мое положеніе, что я не подъ своимъ пменемъ, что подвергаю себя военному суду, и стодьљо убъ-

198) Здъсь должно-быть говорится о Никола' Ивановичъ Неплюевъ, сынъ̆ извъстнаго Ивана Ивановича, служившаго еще при Петръ Великомъ и умершаго въ 1773 году. $M$. II. 


\section{$-150-$}

дилъ его моими резонами и просьбою, что онъ согласился меня отпустить, но съ тьиь, чтобы я не въ Слөнимъ ьхаль (ибо проъзду никакого туть не было) но в'ь Несвижъ, гдъ находятся генералъ-губернаторъ новозабраннаго оть Польши края, Тимоөей Ивановичь Тутолминъ ${ }^{199}$ ), и военный начальникъ той части, генераль-щайоръ Б. $\theta$. Кноррингъ $\left.{ }^{200}\right)$, прибавивпи, что имъ извьстно, гдъ Козловскій полњъ, и тамъ я узнаю, гдеъ безопаснеуе къ нему проьхать.

Получа сіе позволеніе, я безь мальйшаго медленія отправился, и на другой день подъ вечеръ пріґхаль въ Несвижъ. Оставя свой экипажъ въ корчнг, пошель я къ артиллеріи майору Н. И. Богданову; онъ удивился, меня увиджвъ, и спросиль: какъ я сюда попаль? Какь я разсказаль ему о моихъ обстоятельствахъ: «Братецъ), сказалъ онъ мнге, “ућзжай какъ можно скорьй отсюда; нашъ генералъ Кноррингъ самый грубый человъьь; онъ тебъ сдљлаетъ тму непріятностей; поъзжай въ Пинскъ: эта дорога безопасна, потому что по ней идеть сюда три батальона егерей, а въ Пинск' начальникомъ Н. С. Ланской; ты знаешь, онъ самый добродушный человьљъ; Бресть оттуда не далеқо, и тебъ можно будетъ свободно доъхать въ польъ).

Я, простясь съ нимъ, тотчасъ пошель въ корчму, чтобы въ ту же минуту убхать; но капраль мой, встрътивъ меня съ печальнымъ видомь, сказалъ, что онъ только что пришгель отъ генерала, который, потребовавъ его къ себъ, спросилъ: съ кемъ онъ ьдетъ? А какъ онъ донесъ, что съ экипажещъ и людыми Ковловскаго полка майора Энгельгардта, то и приказаль ему пожитки и повозки отдать подь сохра-

199) Тимоөей Ивановичъ Тутолминъ, генералъ отъ инфантеріи, род. 3 января 1740 г., ум. 1 ноября 1809 г. Онъ былъ въ 1806-1809 годахъ главнокомандующимт въ Москвъ. $M$. $\mathscr{I}$.

200 ) Богданъ Өедоровичъ Кноррингь, генераль оть инфантеріи, род. 1741 г., ум. 1826 г. M. JI. 


\section{$-151-$}

неніе въ комиссаріатскій цейхгаузъ, лошадей въ қозачій табунъ, а самому съ людьми явиться къ подполковнику Сакену ${ }^{201}$ ) что́ нынге фельдмаршалъ, принять на всъхъ солдатскую аммуницію и ружья и состоять у него въ командъ. Услышавъ сіе огорчительное повъствованіе, пошель я опять къ Богданову, который, погоревавъ со мною, сказаль, чтобы я къ ґноррингу на другой цень не прежде явился, пока онъ съ нимъ обо мнъ не переговорить, ибо-де онъ съ нимъ только однимъ по-пріятельски обходится; въ противномъ случау онъ мнъ наговорить столько грубостей, что я потеряю терпьнніе.

На другой день, пока не иввъстилъ меня Богдановъ, ви-

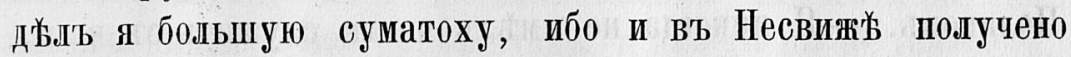
извъ̌стіе, что Поляки идуть атаковать городъ. Въ замкъ иоправляли брустверы, ставили пушки. Тамъ было тогда три роты артиллеріи, три әскадрона Украинскаго легкоконнаго полка, двъ сотни козаковъ; кромь того пришло пять партій рекруть, и изъ Пинска шло три батальона егерей. Генераль долго занимался отправленіемь курьеровъ и партій въ разныя направленія; уже около полудня Богдановъ могъ переговорить съ нимъ обо мнъ. «Ну, сказаль онъ мнь, ступай теперь; я упредиль его 0 теб̆ь, и хотя нъсколько умягчиль его угрюмость, но не вовсе уломаль сего медвъдя).

Я явился къ генералу въ кабинеть, и воть нашъ разговоръ. Онъ спросиль меня самымъ худымъ выговоромъ порусски: “Кто вы таковъ?) - Козловскаго полка преміеръмайорь Әнгельгардть. “Когда пріъхаль?»- Вчера. "Неправда, я не имъ̌љь о васъ записка, а прівхаль съ экипажемъ майора Әнгельгардта капраль Семеновъ».—Әто я, ваше превосходительство; я отпущенъ былъ оть полковника партикулярно. “А, это другой д'ъљъ, явитесь въ команду

201) Графъ Фабіань Вильгельмовичъ 0стенъ-Сакенъ, генераль-фельдмаршалъ, роґ. 20 октября 17 ге2 г., ум. 7 апрьля 1837 г. M. JI. 


\section{$-152-$}

къ подполковнику Сакену; я велю ему вамъ дать сотни двъ рекрутъ, и мы будемъ вмйст'ы драться съ Пөляками.»Ваше превосходительство, я бы за честь поставиль себњ во всякое другое врешя быть въ вапей юомандъ, но судите 0 моихъ обстоятельствахъ: я долженъ отвйтствовать передъ военнымъ судомъ за самовольную отлучку, или показать себя неблагодарнымъ моему полюовнику, сдъълавпему мнъ одолженіе; а притомъ его въ полку нйтъ, и я не знаю, какъ 0 мнг̆ полкъ показываетъ. “А, вы не кочите быть 30 мной; вашъ въ вашъ польъ не можно доихать.»-Я рьшусь на всякую опасность, только чтобы быть въ полюу. “Н̆ъть, г. жайоръ, вы не кочите зъ нами. умиралъ и вы боитесь Поляковъ.»-Я никогда не имъъль чести служить съ в. п., и вы меня не знаете; но ото всъхъ моихъ командировъ я имьљь счастіе заслужить лучшее о себъ мнъніе, а бывъ такъ дурно предупрежденъ вашимъ превосходительствомъ, почту за несчастіе остаться здъсьь, почепу сдъзлайте нилость, отпустите меня. «Вы туналъ, что безъ васъ обойтисъ не можно, изволь вхать хоть къ шорту.» Я не ожидаль ничего болье, будучи очень доволенъ любезнымъ его пріемомъ, а еще болье милостивыпь его отпускомъ; вышель, запрягъ лошадей и, погоняя не оглядываясь, прибылъ благополучно въ Пинскъ.

Николай Сергъевичъ Јанской принялъ меня самымъ добродушнышъ образощъ, увъдомилъ меня, что Козловскій полкъ давно выступиль изъ Бреста и пошель за Вислу въ Сендомирское воеводство присоединиться къ войскамъ, вышедшимъ ивъ Варшавы, и что къ полку мне пробхать невозможно. Онъ совььтовалъ мнґ,, чтобъ я свой экипажъ оставилъ у него, а самъ бы отправился въ Јабунь курьерощъ къ трафу И. П. Салтыкову, командующему всъми войсками въ новозабранномъ краю, откуда уже можно будетъ чрељъ австрійскую Галицію пробраться въ Сендомирское воеводство, гдъ расположены наши войска; но чтобъ я дождался отряда 


\section{$-153-$}

полковнига Чесменскаго ${ }^{202}$ ) изъ Бреста и узналь отъ него про тогдашнія обстоятельства. 0ный отрядъ посланъ былъ въ Брестъ останавливать идущія разныя малыя къ полқанъ гошанды остававшихся за бользнію въ зимовыхъ квартирахъ и препровождать ихъ въ Пинскъ. Почему и я имъ̌ль случай показывать себя за бользнію остававшимся въ Слонимъ. И такъ, дождавшись черезъ день того деташемента, отправился я Волынской губерніи въ мъстечко Јабунь, съ нъ̌сколькими тысячами червонцевъь, которые долженъ быль Јанской переслать къ графу Солтыкову.

При прізздљъ въ Јабунь, у въъзда заставили меня подписать реверсъ, чтобы ни подъ какимъ видомъ я не сказываль никому, откуда прізхалъ, и ничего бы не говорилъ, что̀ мнй извъ̌стно о польскихъ обстоятельствахъ.

Явясь къ его сіятельству и отдавъ казначею привезенную мною сумму, исправно лгаль я 0 моемъ прићлюченіи. Графъ еще повториль мнъ строгое приказаніе, объявленное мне при въъздъ, и объщаль по просьбъ моей при случаһ отправить меня къ полку.

Смбшшно был0, что на вопросъ многихъ моихъ знакомыхъ: “откуда?» я отвъчаль: «не знаю.»- (Зачьмь пріьхалъ?» “Не знаю.) Тиетнал предосторожность тогда, когда уже всъ̌⿱ знали о случившейся въ Польшґ революціи! Поляки распустили 0 ней слухи, съ прибавленіеиъ 0 своихъ геройскихъ подвигахъ.

Черезъ нъсколько дней прибылъ изъ корпуса генералъпоручика Ферзена (получившаго начальство виьсто барона Игельстрома) Углицкаго полка поручикъ Трейденъ, съ которымъ я былъ знаконъ и зналъ, что Углицкій полкъ былъ въ томъ корпусъ. Я атаковаль его, но и ему вельно было говорить: ане знаю». Однакожъ онъ объявиль мнъь, что

202) Александръ Алексъевичъ Чесменскій, сынъ графа Алексъ̆я Григорьевича Орлова-Чесменскаго. М. Л. 


\section{$-154-$}

корпусь въ Сендомирскомь воеводствъ, и тто веъ бывшія наши войска тамъ собрались и ожидають соединенія прусскаго корпуса, подъ личнымъ начальствомъ самого короля Фридриха-Вильгельма, для наступательнаго дъйствія противъ Поляковъ. Я далъ ему слово говорить, что онъ мнб̆ ничего не разсказываль. Но зная и Трейдена лично и то, чт0 он'ь служитъ въ Углицкомъ полку, который быль въ томь корпусж, я просиль графа Солтыюова съ нимь меня отправить. Его сіятельство разгнёвался и сказаль мнь: чтобъ я впередь не осмъљллся проситься, дабы тенмь не подать поводь отгадать о происшедшемъ в' Польшь' ${ }^{203}$ ).

Нькогда его сіятельство сказалъ при всъхъ, что генеральпоручикъ Загряжскій съ корпусомъ двинулся къ Владиміру, Волынской губерніи. Я, вопреки запрещенія, просиль графа, чтобъ отправилъ меня въ оный корпусъ, что̀ онъ мнъ̆ и позволиль, предписавъ тому генералу употребпть меня на службу до соединенія моего съ Козловскимъ полкомъ.

Я уже напель корпусь генералъ-поручика Загряжскаго при Бугъ; авангардъ его, подь командою полковника Рарока, находился у самаго м'ьстечка Дубенки. Его превосходительство приняль меня благосклонно, оставя при себь, а по нбкоторомъ времени я быль имь употребленъ за оберъквартермистра. Полковникъ Рарокъ, какъ Смольянинъ, снабдилъ меня для рыцарскихъ подвиговъ подъемною лошадью изъ-подъ казеннаго ящика и даль мнељ въ услуги одного солдата.

До начатія описанія военныхъ дъйствій, увьддомю $0 \cdot$ революціи, въ Польшь воспосл'ьдовавшей.

х Генераль бароньь Игельстром'ь, видя буйство вь Польшљ,

203) Такими скрытными мелочами познается человьькъ, и служить сему доказательствомь, что когда нужно было благоразумное распоряженіе, то онъ отозванъ, а на мьсто его поступиль кн. Н. В. Репнинъ. 
требоваль приведенія в' то положеніе польскихъ войскт, которое должно быть по силь посль'дняго сейма. Полкъ Дзелинскаго, расположенный въ Варшавґ, прислалъ только 16 человъьъ для опреджыленія въ русскіе полки, представя, тт0 затьйъ осталось у него въ полку помплектное тисло. Бригада Мадалинскаго, расположенная между Бугомъ и Наревомъ, собравъ свои эскадроны у Остроденки, явно отреклась распустить свои войска.

Баронь Игельстромъ послалъ противъ сихъ мятежниюовъ, съ полюощъ карабинеръ, бригадира Багрґева, при приближеніи котораго Мадалинскій пошелъ къ прусской границ'ь', а оттуда въ Сендомирское воеводство, сь такою поспљшшностію, что Багръевъ не могъ его настичь.

Игельстропь собраль въ Варшаву весь корпусъ, расположенный по квартирамь около оной, полки: Сибирскій и Кіевскій гренадерскіе, Харьковскій и Ахтырскій легкоконные, полкъ Донскихт гозаковъ и 20 орудій полевой артиллеріи.

0нъ приказалъ изъ Бреста отрядить генераль-майора Хрущова, съ 6-ю батальонами, 10-ю эскадронами, 6-ю орудіями полевой артиллеріи, однимт полкошь гозаковъ; генералъ-майору Рахманову, изъ Дублина, съ отрядомъ 3 -х' батальоновъ, Һ-хъ эскадроновъ, полком' Донскихт козаковъ и 10-ю орудіями, перейдти Вислу противъ Пулавы. Присоединиться же къ синъ отрядамъ велг̌но тенераль-майору Денисову ${ }^{204}$ ) съ 10-ю эскадронами, 2-мя ротами пьхоты, полкомъ Донскихт козаковъ и леріи. Тоже присоединиться гъ онымъ приказано изъ Кракова изъ разныхъ полковъ небольшимъ отрядамъ, коихъ было около тысячи человйкъ пъхоты и конницы.

201) Графъ Өедоръ Петровичъ Денисовъ, Донской атаманъ, ум. въ 1811 г. Титуль и фамилія его были переданы внуғу его по дочери Василію Васильевичу 0рлову, отцу теперешнихъ графовъ 0рлгвыхъДенисовыхъ. М. Л. 


\section{$-156-$}

Генералъ-майору Тормасову Игельстромъ приказаль съ однимъ батальономъ, двумя ротами егерей, 6-ю эскадронами, полкомъ Донскихъ казаковъ и 4-мя орудіями полевой артиллеріи пресльздовать Мадалинскаго.

Ћакъ скоро Мадалинскій вошелъ въ Сендомирское воеводств0, все польскія войска, расположенныя тамъ, съ нимъ соединились.

18 марта, перепедшіе Вислу отряды соединились у Апотова, и приняль надъ всъми сими войсками команду, какъ старшій, генералъ-майоръ Денисовъ.

Денисовъ продолжаль путь къ Кракову и прибыль 22 марта въ Скальмирцъ, гдъ Тормасовъ, пресльздуя Мадалинскаго, остановился.

Костюшко тогда уже прибыль въ Краковъ, подписалъ актъ возстанія и издалъ свою прокламацію, учредивъ революціонное правительство, и выступиль противъ корпуса генералъ-майора Денисова. Къ войскамъ, собраннымъ имъ въ Ћраковъ и бывшичъ въ Сендомирскомъ воеводствъ, присоединились Мадалинскій съ Ц-ю (или до 6-ти) тысячами регулярныхь войскъ и н危кольго горныхъ крестьянъ (называемыхъ Гарабсъ) и Мазуровъ.

Денисовъ, увъъдомившись 23 марта, что непріятель шел'ь къ Сломнику, въ 3-хъ миляхъ отъ Скальмирца, отрядильъ туда того же вечера Тормасова съ двумя батальонами, двумя ротами, 6-го эскадронами, однимъ полкощъ казаковъ и 8-ю полевыми орудіями.

Въ ночи съ 23-го на 24-е число Денисовъ узналъ, что непріятельская ґолонна тянется вдоль Вислы къ Костюшњъ,

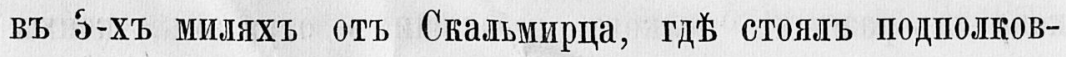
никъ Фризель съ ц-мя эскадронами гусаръ, почему и отрядилъ туда подполковника Јыкошина съ однимъ батальономъ.

На другой день генералъ-майоръ Тормасовъ встрб̆тиль непріятеля при деревнге Раславичи, въ двухь миляхъ отъ Скальмирца. Ћрутой иุ глубогій оврагъ раздйъяль нашихъ 
отъ непріятеля. Тормасовъ донесъ тотчасъ о томъ Денисову, который даль ему знать, что вскоръ съ нимъ соединится, и тотчасъ отправиль своихъ казаковъ, но самъ остался прохлаждаться. Генералъ-майоры Рахмановъ и Хрущовъ не очень охотно повиновались Донскому генералу, уговаривали его пообъдать, потомъ напиться кофею, и такь проволочили время, что уже почти прибыли къ Тормасову Ћъ вечеру; но тогда уже было повдно.

Тормасовъ, увидя изъ-за ль九су казаковъ, думалъ, что весь корпусъ за оными сльъдуетъ, почему ръшшися, не дождавшись, атаковать непріятеля въ превосходныхъ силахъ и попель вдоль буерака искать иьста для удобньйпаго перехода черезъ оный. Непріятель тоже пошель по другой сторонъь оврага. Какт скоро можно было перейдти оный, Тормасовъ атаковаль Костюшку. Начало объщало успьхъ: кавалерія непріятельская не могла выдержать дъйствія нашей артиллеріи и отступила за пъххоту. Тормасовъ бросился на оную, но, по превосходству силь непріятеля и крьпкой его позиціи, Тормасовъ совершенно быль разбитъ, потерялъ всъ пушки, и съ малымъ числомъ едва сауъ спасся.

Денисовъ, видя, что посль̈ разбитія Тариасова весь его отрядъ сталь уже слабъе непріятельскаго, ретировался къ Ћазимиру. На другой день, то-есть 26, прибылъ къ Денисову полковникъ Чичеринъ съ егерей, однимъ казачьимъ полюомъ и ц̌-ю орудіями. Получивъ сіе подкрьиленіе, Денисовъ пошель опять къ Скальмирцу.

Какъ скоро Поляки въ Варшавъ узнали о одержанной Ћостюшкою побъдљ, и объявлена была его прогламація, т0 оная въ ту же ночь прибита была ко всъмъ домамъ, и революція вспыхнула.

Съ давняго времени въ варшавскомъ арсеналь работали день и ночь, заготовляли снаряды и патроны. Барону Игель- 
строму не приходило и на мысль узнать, что́ тамъ дъълается. Поляғи увърилш генерала, что войска польскія готовы вмъсть' съ русскими защищать городъ оть револющіи; Игельстромъ сльњпо имъ повъ̌рилъ. Польскія войска въ Варшавъ̌ были сльъдующія: 2 батальона горонной гвардіи, 2 батальона полка Дзелинскаго, рота венгерской гвардіи, 3 роты канонеровъ, 2 роты артиллерійскихъ фузилеровъ, 80 человъкъ минеровъ и саперовъ, 3 роты охранной газны, 4 эскадрона ґонной гвардіи, 2 эскадрона народо́вой кавалеріи, 3 эскадрона королевскихъ уланъ.

Расположеніе польскихъ войскъ, сдъланное ихъ генераломъ Чиховскииъ, по согласію генералъ-майора Апрагсина ${ }^{205}$ ), занимавшаго должность дежурнаго генерала, было таково: въ арсеналь 1 батальонъ гвардіи, 2 роты артиллерійскихъ фузилеровъ и одна рота канонеръ; у пороховаго магазина 1 батальонъ гвардіи, 2 роты ганонеръ, полюъ королевскихъ уланъ. Прочія польскія войска должны были оставаться въ своихъ газармахъ. Сіе расположеніе было изиънническое, подъ видомъ, чтобы сіи пункты защищать оть черни народной, но настоящая была цъљь, чтобъ удобнъе противу насъ дййствовать.

За откомандированіенъ вт разныя мъсста русскихъ войскъ, въ самомъ городъ было ихъ 9 батальоновъ, 6 эскадроновъ, 300 газаковъ и 18 орудій полевой артиллеріи, кром̌ полковыхъ пушекъ. Расположеніе войскъ было таково: кропґы караула при главной квартирж, двъ роты расположены на квартирахъ близь оной; прочія войска поставлены были на квартирахъ, въ разныхъ частяхъ города по одному батальону съ 2 орудіями; между ними, небольшими частями, кавалерія, для совокупнаго сношенія и поданія помощи одной части войск'ь съ другою. Поляки, чтобъ узнать сіе располо-

$\left.{ }^{205}\right)$ Степанъ Степановичъ Апраксинъ, генераль отъ гавалеріи, род. 1756 г., ум. 1827 г. M. JI. 
женіе, неодногратно дъулали фальшивыя тревоги, а потому взяли свои мъры, чтобы прервать сіе сцжпленіе. Егерскій батальонъ Клугена поставлень быль на мйсть, называемомъ Трє кроля, чтобы не пропускать Дзелинскаго изь казармъ. Бригада генералъ-майора Милашевича расположена была близь онаго.

Баронъ Игельстромъ созвалъ военный совътъ и требоваль мнӝнія: остаться ли въ Варшавь, или со всъмми войсками идти разбить Костюшку и тёмь при самомь начал'ь задупіить революцію?

Причины не оставлять Варшаву были слььдующія:

1) Единственно изъ варшавскаго арсенала могуть польскія войска быть снабжаемы, безь чего Костюшко, не имья потребныхъ снарядовъ, долженъ вскорь разными русскими и прусскими отрядами быть истребленъ. 2) Ежели оставить Варшаву, всъ польскія войска, соединясь, присовокупя ю'ь тому вольницу варшавской буйной черни, составять

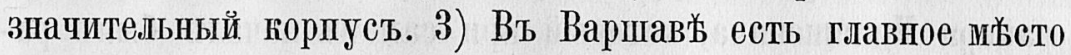
непреп宂ннаго правленія, преклоннаго къ нащъ, которое, какъ и всъ приверженные къ Россіи, подвергнутся опасности, преданные въ руки непріязненной партік. 4) Король не можеть остаться безъ насъ въь Варшав'ь, а пожелаеть ли онъ выъхать съ нашими войсками? Если же онъ поъдеть, то какая будеть тягость за собою возить и оберегать его?

Совъть, внявь сіи обстоятельства, ржшительно положиль: остаться въ Варшавњ。.

За нъссколько дней до 6 апрьеля, казалось, все успокоплось. Однакожь была молва, что, накануньь вечеромъ, изъ арсенала въ окошгки выброшено было для черни до 丂̆0,000 патроновъ.

6-го апръля 1794 г., вт четыре часа утра, небольшой отрядь конной польской гвардіи выступиль изъ казармъ и напаль на нашъ карауль, поставленный между сими казармами и желъззными воротами Саксонскаго сада. Карауль 
выстрблиль два рава изъ пушекъ, принужденъ оставить ихт и отступить, а польскій тоть отрядъ, подрубивъ у лафетовъ колеса, возвратился въ казармы. Послгы сего вся конная гвардія выступила; часть отправилась къ арсеналу, а другая къ пороховому магазину. Сею атакою началось непріятельское дъйствіе. Вскорь сигнальными пушечными выстрълами изъ арсенала дали знать: польскимъ войска̀мъ быть на назначенныхъ местахъ, а черни собираться.

Изъ арсенала выдавали черни ружья и сабли; во всешъ городё было слышно: до брани! рамуїте отиизну!

Народъ заняль дома, близь которыхъ расположены были наши войска; изъ окошекъ стали по нищъ стрьлять, бросать каменья и все чьымъ ни попало. Многіе офицеры не могли прибыть къ своимъ командамъ; сношеніе нашихъ войскъ было прервано; рьддкія генеральскія приказанія доходили къ кому посланы. Полкъ Дзелинскаго обошель пость батальона Ћлугена другою улищей и атаковаль генеральмайора Милашевича, который при самомь началь' быль раненъ. Полковникъ князь Гагаринь быль раненъ и потомь народощъ убить. Войска напи не скоро собрались на назначенныя м'ьста, и разстройство сдъ̌блалось общее. Квартира барона Игельстрома была атақована со всъхъ сторонъ. Хотя неоднократно возмутители были отражаемы, но число ихъ безпрестанно умножалось. Одинъ только батальонъ майора Вимпфена прибыль къ генералу, да подъ вечеръ пробился съ батальономъ майоръ Титовъ. При главной ґвартирґ находились: генералъ-поручикъ Апраксинъ, генералъ-майорь гр. Н. Зубовъ $\left.{ }^{206}\right)$, генераль-квартирмейстеръ Пистерь.

${ }^{206}$ ) Графъ Николай Александровичъ Зубовъ, оберъ-шталмейстер'ь, роц. 24 апрґля 1763 г., ум. 9 августа 1805 г. Онъ быль женать на дочери Суворова Натальљ Александровнъ, род. 1775 г., ум. 30 марта 1844 г. $M$. II. 


\section{$-161-$}

Въ началь' сражепіе происходило на Сенаторсгой улиц и у дома, занимаемаго главнокомашцующимъ; по меочимъ атакамъ и отраженіямъ, наши войска занлли дома гоммиссіи. Отъ горолт присланъ былт генераль Бишевскій съ

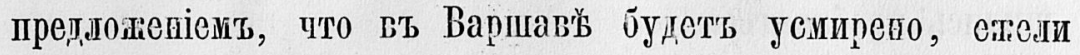

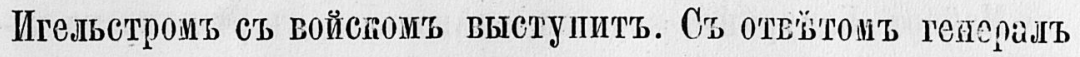
посталь своего племлниига, подполюовнига Игельстрома, ко-

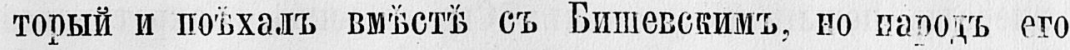

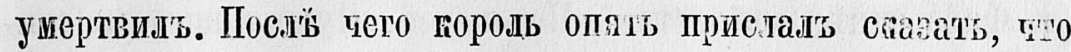
ежели Игельстрой жедает" выстулить ивъ Верішасы, то онъ бељъ оружія могеть выйдтк. и навпачено ену будетъ по кақимъ улицамъ проходить; на сіе предыотеніе ве дано было отвйта. Весь тотть день сраженіе продолталось.

На другой день поутру сраженіе оплть воюојнозиось, но

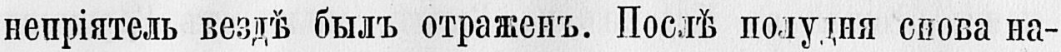
чались нападенія. Безпрепятственно, съ псбольпо по потерей, можно было бы, оставя Варшаву, соединитьст со всы̆ми войсками; но Ительстромь ниғагъ не хотйыъ оставить ни города, ни дома, въ готоронт онъ жијь. Прочія паши войска въ разных' частлхъ гореда, не получал ниғатого приказанія, претерпььвали поратеніе. Гснералт-майорь Новиџкій вывелъ нйвоторые батальоны въ Іерусалимскіе ворота ғъ парту нашей артиллеріи, стоявшей у Воли; многіе батальоны сами собою $\mathrm{Fт} \mathrm{оной} \mathrm{присоединились,} \mathrm{оставя} \mathrm{генерала}$ въ самомь гритическомь положеніи. Тенераль-артилдеріи Тищевъ былъ убить. Прусстій генераль Волки́, пачальствовавшій войскани близь Варшавы, прббыль тьь опой, имйя съ собою не больве тысячи человььь и располотилея у кладбища, по правуго сторону пороховаго магавина.

Въ ночи на 8-е число сожгли всьь бунаги, находивтіяся въ канцеляріяхъ генерала. Јишь толью стало разсвьтать, Поляки начали атаку. По сему наши принуждены были, оставя домъ генерала, занять дворъ комииссіи. Ве'ь огруяныя улицы наполнены были непріятельскою артиллеріей, 
войсками и чернію. Макрановскій прислалъ парламентера и требовалъ, чтобы генералъ, положа оружіе, сдался на дискрецію. Оставалось нашихъ войскъ не болье четырехъ сотъ человъ̌къ, и при оныхъ четыре полковыя пушки. И тақъ ръшились пробиваться.

Майоръ Батуринъ, видя еще ны̆которое въ ръишимости колебаніе, сказалъ: “Извольте идти за мной». Пустя двъ̆ пушки впередъ, пошли по улицамъ: Свентоярской, Сакротинской и Фавориткь, к' заставъ̆ Повонской. Пушки впереди очищали нашимъ путь, а заднія двъ пушки прикрывали отступленіе, но на всяғомъ шагу должны были выдерживать сильный пушечный и ружейный огонь, особливо изъ домовъ; и такъ нағонецъ соединились съ прусскими войсками. Отдохнувъ въ деревнъ Бабичъ̆ до четырехъ часовъ пополудни, наши отошли въ Модзинъ къ Вислґ, милю отъ Варшавы, гдё и ночевали. Сабурову, пригрывавшему госпиталь, приказано было идти къ Новигроду, на устье Наревы, гдь̌ ему и переправиться. Туда прибыли еще три роты Петербургскаго полка. 9-го числа наши прибыли въ деревню Счерскъ; тамъ только Игельстромъ узналъ, что съ Новицкимъ вышедшія войска чрезъ Карчевъ въ Ловичахъ (Сендомирскаго воеводства) присоединились къ прочимъ нашимъ войскамъ.

Баронъ Игельстромъ получиль повел'ьніе ьхать въ свои деревни въ ЛиФляндію, а войска поручены въ командованіе генералъ-поручику Ивану Астаөьевичу Ферзену.

Въ самый день рев̀олюціи въ Варшавъ̌, Поляки отиравили прокламацію Костюшки во всю Полышу и Литву, а равно увйдомленіе о пропсшедшихъ обстоятельствахъ.

Въ Вильнъ заранъе гетманъ Косаковскій предувъ̆домлялъ генералъ-майора Арсеньева, что готовится революція, чтобъ онъ былъ остороженъ и взяль свои мьры; но тотъ былъ въ интригё съ паньею Володковичевою: какъ къ ней, такъ

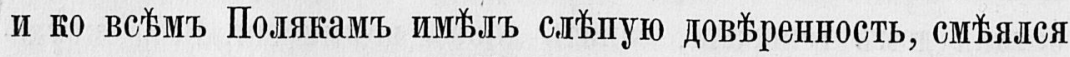
со всъии ими о страхъ Косаковскаго, который наконецъ 
писалъ къ нему: «что Ц̆-й и 7-й Литовскіе полки идутъ въ Вильну, и что онъ насилу могъ отъ нихъ убхать и будетъ самъ съ приверженными въ Вильну часа черезъ два». Случилось сіе вечеромъ, когда у Арсеньева были всь мнимые его друзья Поляки. Онъ показаль имъ записку Косаковскаго; ть' увьрили его, что то была совершенная ложь; но когда разъ'ххались, Ћосаговскій пріххаль ночью въ Вильну и тотчасъ послалъ за Арсеньевымъ, но уже было поздно. Ударили въ набать; Поляки бросились на гауптвахту и на сонныя квартировавшія наши войска. Полки Нарвскій и Псковскій большею частію были захвачены въ пльнъ, а сопротивлявшихся умерщвляли безъ всякой пощады. Самого генерала Арсеньева взяли на чердак', спрятавшагося за трубу; въ числь пльнныхъ взять былъ и полковникъ Языковъ. Косаковскаго взяли на квартир'ь, но онъ защищался храбро до тъхъ порь, пока выстрблиль всь бывшіе съ нимъ заряженные пистолеты и многихъ нападавшихъ на него убиль и раниль. На другой день его повъсили ${ }^{207}$ ).

Артиллеріи капитань Сергъй Алексъевичъ Тучковъ, къ счастію, по первопу удару въ набать, вскорь ушель къ своимъ двумъ ротамъ артиллеріи, стоявшимъ на Погулянк先, и нашель всю свою команду готовую у орудій. мал0-по-палу стали прибъгать оть сказанныхъ полковъ нбкоторые офицеры и нижніе чины, и собралось ихъ до 700 человыьъ. Онъ подступиль къ городу и сталь оный канонировать; Поляки хотьли было его атаковать, но видя устройство его войскь, опасались. Поляки потребовали оть Ар-

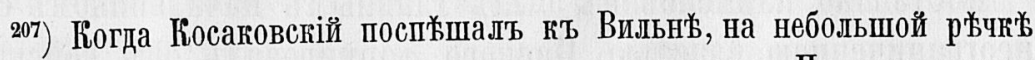
подломился подъ нимъ ледъ, и онъ едва не утонулъ. По сему случаю надписали на висилиць его: Co ma wisiec ne utonie, т0-есть: «டому быть повъшену, тотъ не утонетъ». Должно сказать, что Поляки имьљли справедливую причину его ненавидъ̌ъть; дййствительно, онъ быльь измьнникъ своему отечеству, а при томъ ни одинъ человьћкъ из'ь Русскихъ не сдълалъ столь много озлобленія Полякамъ, какъ онъ. 


\section{$-164-$}

сеньева, чтоб̈ъ онъ приказаль Тучкову остановить канонаду, но тотъ отказался, а приғудили полюовика Языкова, чтобъ онъ оть имени генерала послалъ таповое притазаніе. Тучковь, получа сіе предписаніе, отвйчаль, что пока генерала лично не увидитъ, то приказа не послушаетъ, и требоваль, чтобы его ему выдали. Но кағъ начало разсвътать, и онъ увидёьљ, что польскіе полки собрались и вывезли изь своего арсенала артиллерію, то, по малому числу своихъ войскъ, ретировался онъ къ Гроднь̌ и прибыль туда благополучно безъ мал'ьйшей потери, хотя при начальь жарко быль пресльйдемг.

Въ Гроднге гомандовалъ генералъ-майорь княвь Пав. Пмитр. Циціяновъ $\left.{ }^{208}\right)$. Ћакъ человйь разумный и съ воинскими особливыми дарованіями, онъ быль остороженъ и содержаль войска въ должномъ порядкй, и потому то'часъ по дошедшей молвй принялъ свои мйры: дождавшись Тучкова, взлль съ Гродны гонтрибуцію, заняљъ грьипую позицію и оставалсл там до времени.

Между тймъ Поляљи предались совершенно духу Французской револиціи. Многіе знатные Поляки были перевъшаны, въ числ'ь которыхъ: князь Масальскій, бискупъ Виленскій, Ожаровскій и Четвертинскій. Ћолонтай играль роль Робеспьера: хоть̆ль было всь̆хъ Русскихъ перергъзать, но Костюшко, заврешенно прибывъ въ Варшаву, до злоды̌йства сего не допустиль. Посльь, гогда уже Прага, предмъстіе Варшавы, Русскими была взята и передъ занятіемъ самой Варшавы, Колонтай ушель съ большою сумиой денегъ.

Ћостюшко наименованъ былъ главнымъ начальникомъ съ неограниченною властью. Наскоро формироваль онъ войска,

208) Князь Павелъ Дмитріевичъ Циціяновъ, генералъ отъ инФантеріи и главнокомандующій въ Грузіи, род. 1734 г. Әтотъ внаменитый полководецъ былъ измьннически убитъ старшинами города Баку, 8 Февраля 1806 г. M. J. 
умноживъ регулпрные полки вольницею, такъ что въ каждомъ полћу былъ тройной комплектъ. Кавалерію паны снабдили хорошими лошадьми, отщали всь̌хъ своихь охотниковъ, поторые были ислусные стр'љли; войска усилили «посполитымъ рушеніемъ), т0-есть: всь шляхтич, жиеущіе на-

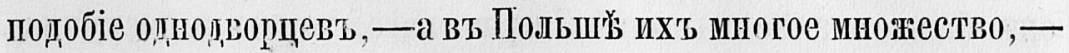
должны были вооружиться; сверхъ того набраны были крестьлне: не имьвшіе досгаточнаго оружія, они ворружены были госами наподобіс пинь. Сь гтавнуьйшими силами

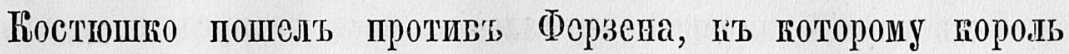
Прусскій присоединился съ вначительнымъ корпусомь. 乌айончегт навначснб былт противитьст со сторожы Прасеой

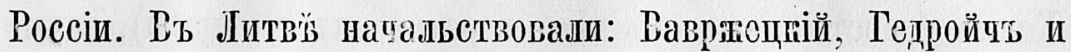

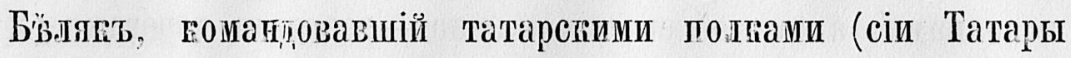
поселены были въ Виленскопъ воеволств"ь и отчасти въ Гродненстомь, и сиабтили 16 әстадрошовг). Но есьь сіи гольскіе генералы, ни тсоретичесғой, ии прагтической войны не внали; ностӥ Ћостошии сшитался у нихь пучшимъ Домбровсгій, служившій в'ь сапсонской слупй'ь полюовнигомъ.

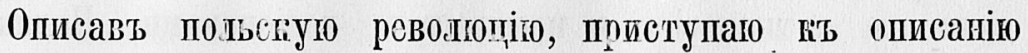
военныхт ды'̆йствій.

Полговниюь Рарогъ, помандующій авангардомъ отряда г. II. Загрғжскаго, донесь, что Полжии појтру вг 4 часа, въ числь' тысячь восьми и бол'sе, заняли, оть Дуӧенки верстахт въ двухъ, ту самуго позицію, поторую занималь Ћ0стюшко противъ арміи Ћаховсіаго, и что уже сь его каваюами начали перестрйлу. Весь нашт отрядъ состояль изъ 10 батальоновь, 12-ти әскадроновъ, 1 полка Донскихъ казаговъ и 10-ти опудій полевой артиллеріи.

Не сниная лагеря, весь отрядь выступиль къ Дубенкъ; пога оный приближалст, Поляки выслали эскадрона четыре на шармицель, но гагь скоро усмотрьли, что два батальона 00х0дять ихъ позицію, а отрядь шелъ прямо къ нимъ въ шицо, то они и ретировались гь льсу, а потомь и совсь⿻ы 
ушли къ Хелму. Пльннные показали, что то была рекогносцировка, но польскія войска у Хелма были въ большомъ числь̌ подъ командою генерала Зайончека.

Черезъ день посль незначащаго сего дъъла, прибыль съ корпусопъ генералъ-поручикъ Дерфельденъ ${ }^{209}$ ). Такъ какъ онъ былъ старъе въ чинъ Загряжскаго, то онъ и поступилъ къ нему въ команду. Авангардъ порученъ генералъ-майору гр. Валеріяну Зубову; онъ составленъ быль изъ 4-хъ батальоновъ, 6-ти эскадроновъ, 1 полка Донскихъ козаковъ и 4-хъ орудій полевой артиллеріи; весь корпусъ состояль болье ч九̆мъ изъ 15 тысячъ человььк.

На другой день пошли атаковать Зайончека, бывшаго при Хелиґ (разстояніеиъ отъ насъ верстахъ въ тридцати), двумя колоннами, а для облегченія марша - разными дорогами. Я юомандовалъ авангардомъ колонны генерала Загряжскаго; дорога черезъ льзсъ была чрезвычайно дурна и разстояніемъ дал为е той, по поторой пошель Дерфельденъ. Мы пришли спустя часъ, когда началось дъъљо. Лишь только вступили мы въ линію и открыли канонаду противъ построеннаго редута съ артиллеріею и прикрытаго косіонерами, Поляки, оставя редутъ, побъжали, но орудія успъли увезти; одно только увязло въ болоть, юоторое взяль нечаянно Низовскаго полка адъютантъ Гололобовъ. Стоящимъ на правомъ Флангъ легкоконнымъ двумъ полкамъ вельно было атаковать народо́вую кавалерію, прикрывавпую бжжавшихъ косіонеровъ. Положеніе мъ̌ста было болотистое, къ намъ клиномъ сузившееся, а къ непріятелямъ шире; за симъ болотомъ былъ ложементъ, въ которомъ помьщенъ былъ непріятельскій батальонъ. Лишь только полки наши пошли въ атаку, какъ болото заставило ихъ ть̌сниться къ Флангамъ,

${ }^{209)}$ Вильгельмъ Христофоровичъ Дерфельденъ, генераль оть кавалеріи, родомъ әстляндецъ; род. 173ٌ г., ум. 3 сентября 1819 г. Онъ быль любимецъ Суворова. $M$. 
почему и разстроились; изъ ложемента открыть быль по нихъ ружейный огонь; народо́вая кавалерія ударила на оба Фланга и обратила нашихъ въ бћгств0; Дерфельденъ вельль сдь̆лать ньсколько выстрььловъ ядрами по непріятелямь и своимъ, что́ заставило нашихъ остановиться, а непріятелей ретироваться. Тъмъ и дъъло кончилось, съ небольшою нашею потерей. У непріятеля убито было болье трехъ соть чело-

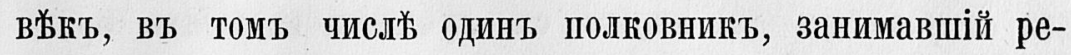
дУтъ; много взято въ пльнъ косіонеровъ, которые, какъ неохотно сражавшіеся, отпущены по домамъ.

Случилось мнь съ подполковникомъ Мейеромъ пробзжать мимо базиліянскаго монастыря въ Хелм̌, оть мъста сраженія верстахъ въ трехъ. У сего монастыря поставлены были маленькія чугунныя 4 пушки, ивъ которыхъ стрбляли во время церковныхъ праздниковъ и каковыя у встхх шочти польскихъ костеловъ бываютъ, и которыя посль положены были на мужицкую тельгу и съ лафетами. Мейеръ сказаль мнъ: «поъдемъ поскоръе, чтобы не подумали, что мы хотимъ присвоить себњ честь взятія сей страшной батареи». Но представьте мое удивленіе, когда я увидъљљъ въ реляціи, что сію батарею взялъ майоръ Шепелевъ, за что̀ данъ ему былъ георгіевскій кресть. Какъ поносно начальству дйлать таковое злоупотребленіе и безчестить сей почтенный орденъ! Но къ несчастію, не одинъ сей быль таковой примьрь: люди достойные и дъйствительно заслужившіе бывали безъ всякаго награжденія, потому что не хотьлли подличать, а самохвалы и подлые льстецы были осыпаемы почестями.

На другой день пошли всльдъ Зайончека въ Красный Ставъ; но онъ такъ скоро бъжалъ, что не могли его настичь, и онъ переправился черезъ Вислу при Пулавъ, имъніи князя Чарторижскаго, который много способствовалъ къ поощренію революціи, снаб̆жая Костюшку деньгами. Не доходя до оной десять версть, корпусь остановился. Дерфельденьь имъль повел务ніе имъній Чарторижскихь не щадить, 


\section{$-168-$}

для чего Пулава была разграблена до основанія. Сады и парки не уступали располотеніем'ь и красотою Царскому Cелу; богато уграшенный огромный домъ разоренъ, картины ияорьаны, библіотека, состолвшая ивъ 40 тыслчъ в0люмов' нымъ сочиненіемъ не воспользовалея, кромь̆ подполғовника С. Н. Щербачева, готорому удалось приготовлепные, видно, дыя отправленія два ящина с'ь лучшими ивданіями французспихь книг' себъ присвоитьь. На'уральный кабинеть весь былъ разбитъ, а превосходное собраніе окаменъ̆лостей все раздробтено.

'уу'ть голучили оть Прусскаго көроля увъдомленіе, что онъ, соедипиеъ свого арімію, состольшуг ивъ 30 тысячъ

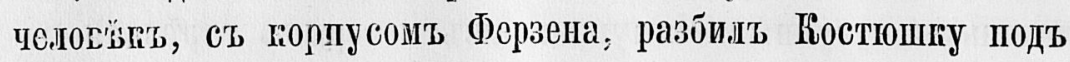

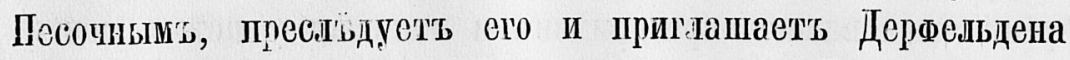
перейдти Вислу и преградить отступленіе Костюшй къ Вапшавъ. Мы сь восхищеніемы были уже тоговы сіе исполнить, пағъ получили повелйніе о'ь пнтвл Репнина, поему

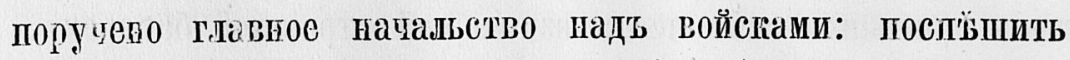
къ Несвияу, несмотря ни на гакія обстолтсльства, ибо грашица Россіи угроғастсл сильными млтежными войсгами. Поуену Дербельревъ, по всеобщему огоршенік, принуждеаг иылъ, во испіолненіе того ордера, на другой день выстулить.

Не доходя до мъстечка Брестовичъ, узнали, что генералъ Маграновспій расположенъ быль съ горпусонь въ 10-ти

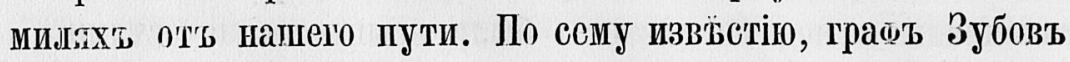
выпросіль' позволеніе съ сеоим'ь авангардом'ь атағовать его; но приблитась къ нему мили ва тетырс, узшаль, что онъ нарочито силенъ, и просиль подгрёншенія, - для чего Загрлжскій съ своимъ отрядомъ быль посланъ. Кагъ графъ Зубовъ быль генераль-майоръ, то и хоть̆ыъ, чтобы Загряжскій приняль начальств 0 , а тотъ отъ того оттоваривался ть̌Мъ, что посланъ только его подкрйпить. И таґъ не согла- 
сясь между собою, оба возвратились въ норпусъ и продолжали маршъ до Слонима.

Пробывъ тамъ нйсгільгіо дней, гнязь Репнинъ приказаль оставить для прикрысія россійских'ь грапицт генераль-майора Јассія съ 4 -мя батальонами и $\overrightarrow{\mathbf{6}}$-10 эскадронами, а всему корпусу идти нъ Вильны: ибо генералъ-майор'ь Кноррингъ безуспйшно атаговаль онуг, и Поляки сильно ему проти-

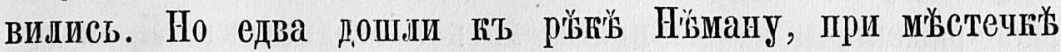
Бйлицй, получили допесеніе оть Јассія, тто онъ атаєованъ Сираговскимъ съ ғороннымъ войскомь, татарскими полғами Бйылка и посполитымъ рушеніемъ, всего до 18 т. человйкь. Почену генераль-поручиғъ Загряжскій гомандированъ съ своимъ отрядонъ идти форсированным' маршемъ на сикурсъ. Оть Бжыицъ до Слонина оголо 12 нймецгихъ миль; мы шли почти бељь ровдыху и череэъ 22 часа ппод Слонимомэ соединились съ Јассіемг. Поляки хотйыли переправиться черегљ рюьку Щару по плотинъ, простирагощейся на версту и на которой устроена была болышая мельница, нашими тогда сожтенная. Не воирая на несоразмърныл силы и храбрый папорь Поляковт въ продолженіе 8-ми часовъ, храбрая вапита плотины полковнигомб Коновницынымъ ${ }^{210}$ ) съ его Старооскольскимт полгомь сдъљала покушенія ихъ тщетными. Съ другой стороны Щары, непріятельскою батареей, устроенною изт 20 орудій, много убито у насъ людей: однихъ ганонеровъ въ Старооскодьскомъ полку уо̆ито три комплекта. Непріятель, видя безуспґшпе усиліе переправиться, къ вечеру уже прегратиль канонаду и отступилъ версты на двй о'тъ р'̌ки. Лассій тоже отступиль' на недальнее разстояніе къ опушкъ льсса и посылаль своихъ людей небольшими частями показываться въ разныхъ мь-

210) Который былъ потомъ генералощъ отъ инбантеріи и дежурнымъ генералощъ главнаго штаба императора и въ томъ званіи јмеръ. 


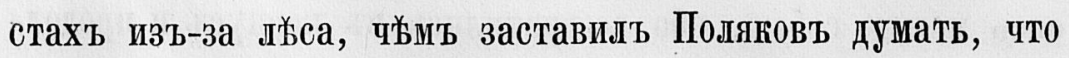
онъ получилъ подкржыленіе.

По соединеніи корпуса, положено было въ совъ̌ть̌, чтобы въ ту же ночь перейдти Щару у Жировицваго Базиліянскаго монастыря, вверхъ отъ Слонима въ Ц̆-ти верстахъ, и зайдти непріятелю въ тыль; для чего, какъ я былъ за оберъ-квартирмистра, позвали меня для сдйыанія должнаго распоряженія и чтобы приготовить проводниковъ. Я, квартируя въ Слонимъ зиму и будучи псовый охотникъ, всъ мистоположенія зналъ; зналь и т0, что отъ Слонима по правой сторонь⿻ къ Жировицамъ были непроходимыя зыби, и, чтобъ оныя обойдти, надобно было окружить по крайней

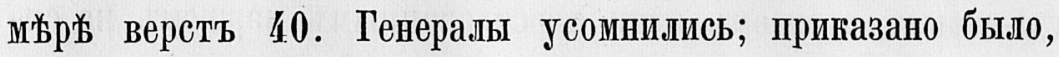
по обыкновенію, представить Жидовъ, чтобъ отъ нихъ 0 томъ развъъдать. Жиды мое показаніе утвердили, почему планъ сей былъ оставленъ. Мнъ̌ приказано было построить портативный мостъ; Щара ' тутъ была шириною саженей четырнадцать, глубиною аршинъ около трехъ, а въ нъ̌кторыхъ мъстахъ и глубже. Черезъ два дня мостъ бынъ готовъ, положенъ на воловыя фуры, и опредйленъ къ оному Херсонскаго полға корнетъ, казалось, человьькъ исправный.

Дерфельденъ и самъ съ корпусомъ возвратился и увъ̌домилъ, чт0 онъ намъренъ сдълать обходъ, зайдти непріятелю съ тыла, и что когда дасть знать, тогда Загряжскій, переправясь по приготовленному мосту, атаковаль бы его въ лицо, въ ожиданіи же того предупредительнаго повельннія корпусъ быль бы въ ежеминутной готовности.

Вмъсто того чтобы зайдти съ тылу и заранъе дать намъ знать, Дерфельденъ шель по другой сторонъ Щары отъ Деретчина, и мы, не бывъ извъщены, увидйыи уже его аванпостъ казаковъ, вступившихъ съ непріятелемъ въ перестрьлку. Корпусъ выстроился, но мостъ замедлилъ двинуться къ назначенному мъсту переправы. Я приказаль сказанному опредъъленному къ мосту офицеру, чтобы повозчиковъ ни- 
куда не отпускаль и воловъ кормиль бы у самыхъ фуръ, но онъ въ точности того не исполнилъ, въ чемъ, безъ всякаго оправданія, была моя оплошность: ибо, положась на подчиненнаго, я самъ надъ нимъ не надспатривалъ. 0днакожъ наконецъ мость быль поставленъ; я первый съ двумя гренадерскими ротами и двумя орудіями по оному переправился, а за мной и весь отрядъ; но Дерфельдена корпусъ насъ опередиль. Впрочемъ, ежели бы моею оплошностію мы и не промь̆шкали, все бы не успьли атаговать непріятеля прежде Дерфельдена и помишать ретирадъ Сираковскаго, который, видя превосходящія его силы, наступающія на его флангъ, ретировался за дифелеи къ Кобрину.

Дерфельденъ жаловался князю Репнину на Загряжскаго, чт0 онъ причиною того, что непріятеля упустили, а пакъ тотъ расположенъ быль лучше къ Дерфельдену, нежели къ Загряжскому, т0, не разобравъ обстоятельства, дб̌лалъ посльдднему строгіе и несправедливые выговоры, почему Загряжскій отпросился и побхаль въ Россію. По короткому обхожденію бывшаго моего командира съ графомъ Зубовынъ, онъ упросилъ его, чтобы позволиль мнъ быть при неуъ волонтеромъ, на что̀ онъ съ большою ко мнё благосклонностію согласился. И такъ я сталъ волонтеръ противъ воли.

При графъ Зубовъ было насъ волонтеровъ однихъ штабъофицеровъ человъ̌ъ съ сорокъ; мнг было тогда двадцать семь ль̈ть, а льтами я быль всъхъ старъе. Въ числь оныхъ былъ графъ П. Х. Витгенштейнъ ${ }^{211}$ ) и А. П. Ермоловъ ${ }^{212}$ ). Мнъ было пріятно то, что я жилъ во все продолженіе кампаніи у полковника Рарока, бывшаго съ полкомъ въ авангардъ у графа. Такъ какъ я не имъљљ своего эқи-

211) Князь Петръ Христіановичъ Витгенштейнъ, генералъ-фельдмаршалъ, род. 25 дегабря 1768 г., ум. 30 мая 1843 г. M. JI. 212) Знаменитый Алексъй Петровичъ Ермоловъ. $M$. J. 
пажа, то до сего во всемъ нуждался, а тогда я уже быль какъ бы у себя и во всемъ имгыл изобиліе.

Ћнязь Репнинъ предписалъ Дерфельтену, чтобъ онъ осталсл въ Слонимь и нахопящагося за дефилеями, расположеннаго при Ћобрпнй, Сираковскаго атаговать не осмгљливаля. Туть предсталь случай, чрезъ который князь Багратіонь пріобрқыль славу, искавъ смерти. Каюь заслуги его были столь вслики и столь извйстны, то я 0 семъ умолчу; но въ посль̌ыствіи кампаніи онъ съ эскадрономь бросался въ пресль̆дованіе Гедройча и Вавржсциаго сь таңого отчалнною храбростію, что одинъ равьь еъ преслйыованіи непрілтельскаго арьергарда подь всыерь зазххаль вь непріятельскій лагерь и навель ужаст; нйсколько рай бросалсп на п'ьхотныя юотонны, за тто́ вт одну сію пампанію справедливо получиль владимірскій оппень и чинь ${ }^{213}$ ).

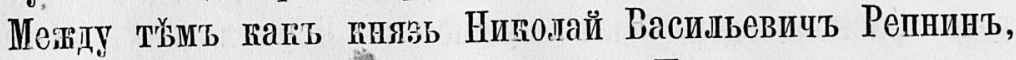
будучи въ Несвижь, боллст, ттобы Поляки не вторглись въ россійскія границы, Грабовскій съ небошьшото партіей прпгрался чрезъ Минскую губерніко къ Б'ьлоруссіи. думая, что тамь недовольные россійскимь правительствомь воз-

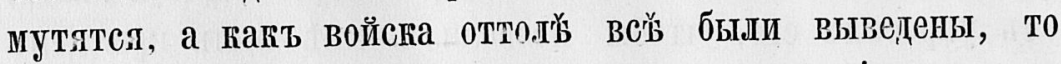
симг отважнымь предпріятіемъ отвлечеть русскія сины изъ Польши, въ чемъ онъ очень ошибст. Княвь Циціяновъ, свьудавъ о томъ, съ своимъ небодьшимъ отрядомъ истребилт его, не допустивъ до Рогачева.

Графъ Суворовъ, по порученію фельдмаршала граба Петра Александровича Румянщева, увидъвшаго худые успьхи Русскихъ въ Польшъ̌, собравъ корпусъ тысячъ въ дв"'надцать близь Варковичъ, внезапно при Ћобринг' разбиль Сираковскаго, который отступиль къ Ћрупчицамъ на крйпкую по-

213) Князь Петръ Ивановичъ Багратіонъ, генераль оть инфантеріи, род. 1765 г., ум. 7 сентября 1812 г. отъ раны, полученной подъ Бородинымъ. M. I. 
зицію и получиль сильное подкрӝленіе, но и тамъ вторительно быль истребленъ. Посльь сего, не давая ни мало отдыха, Суворовъ истребиль сильный горпусъ, бывшій у Брестъ-Јитовскаго подъ командою Макрановсгаго. Во всъ̌хъ оныхъ дйлахъ 2与 тысячъ человйьъ Поляковъ съ ихъ артиллеріего какъ будто не бывало $\left.{ }^{214}\right)$. 0нъ прошель въ три недъ̌ли оголо пяти сотъ версть.

0 вс"ъ̌х' сихъ дъ̆йствіяхъ мы узнали вдругъ. Костюшко, увъ̆домившись о сильнощъ пораженіи его войскъ графомъ Суворовымъ, предписалъ всь̌мъ оывшимъ польскимъ войскамъ въ Јитвж, оставя оную, соединиться съ нимъ. Князь Николай Васильвичь рересталь страшиться и приказаль Дерфельдену тйснить отступаюція литовскія войска. Съоро мы настигли оныл, и до самаго Бйылостока ежедневно происходили арьергардныя дъ̌ла, подавшія случай къ счастію, какъ я выше сказалъ, князя Багратіона.

Въ продолженіи нашихъ дъйствій, король Прусскій съ соединенною арміей, безуспгьшно державъ Варшаву въ блокадь̌, отступиль къ своичъ границащъ. Польскій генераль Домбровскій пресль̆довал'ь ІІрусссія войсна ст постоянными выгодами. Ферзенъ ${ }^{213}$ ) потянулся вверхъ по Висль.

Князь Репнинъ хотб̆лъ тыъъ оғончить кампанію, и мы получили отъ него повельніе вступить въ квартиры. Но вдругъ граФь Суворовъ прислаль ордерь къ Дербельдену, извъщая, что Ферзенъ, переправясь черезъ Вислу, подъ Мацеевичами, разбиль Костюшку и взяль его самого въ пль̌нъ, и что хотя ДерФельденъ с’ь корпусомъ и не состоить

214) При Брестй польскія войска стояли за рйкою и городомъ, ожидая непріятеля съ большой дороги; но Суворовъ, оставя пьхоту съ артиллеріею въ виду Поляковъ, самъ съ конницею ночью переправившись черевъ Бугъ, обошелъ и ударилъ на непріятеля въ тылъ; Поляки, изумленные, всъ̌ были истреблены.

215) Графъ Иванъ Евстаөьевичъ Фервенъ, генералъ отъ инфантеріи, ум. 1799 г. M. I. 
у него въ командъ, но чтобы симъ воспольвоваться и одним'ъ ударомъ поразить гидру мятежа, Суворовъ именемъ ея величества повельваетъ форсированнымъ маршемъ гнать ретирующіяся литовскія войска и съ нимъ соединиться, а князю Репнину о томъ сообщить. Дерфельденъ колебался въ томъ повиноваться, но графъ Зубовъ настоялъ, и мы тотчасъ выступили. На пути прибыли в' корпусъ 700 казаковъ Черноморцевъ, которые поступили въ авангардъ; кошевой Чапега съ своимъ полковникомъ, обвьшаннымъ крестами, явился въ команду къ граФу и, проходя одно мъстечко, увидьвьъ поросять, сказаль своему полковнику: “Алексъй Семеновичъ, видишь, какіе гладкіе поросята, чего глядишь?» Тотъ сейчасъ соскочиль съ лошади, нъ̌сколько ихъ поймалъ, закололь и положилъ къ себъ. въ торбу. Воть какія войска!

Мы уже настигли арьергардъ Гедройча при переправъ его черезъ Бугъ, бливь деревни Поповки, какъ Черноморцы донесли, что Поляки, переправившись, ломають мостъ, а по той сторонь' в’ь льсу засьли ихъ егери съ пушкою и не допускають Черноморцевъ тому воспрепятствовать. Графь Валеріанъ Александровичъ быль съ Софійскимъ карабинернымъ полкомъ и всъми, при немь бывшими, волонтерами; полюовниюъ Рарокъ, посадивъ своего полка гренадеръ на лошадей изъ фрунтоваго обоза, прискакалъ къ графу. ПодъҺхавъ къ берегу, чтобъ узнать, въ которомъ мъсть быль тотъ мость, Рарогъ сказаль: “Господа, разъъзжайтесь: непріятель, увидя генерала, окруженнаго столь многочисленною свитой, будетъ по немъ стрљлять". Мы только-что отъ него отъьхали, и я быль отъ графа шагахъ въ десяти, какъ вдругъ роговое ядро, фунта въ полтора, оторвало у графа льъвую ногу, а у Рарока правую, и то былъ отъ нихъ посльвдій выстрьљљ. Графа отнесли въ лощину; со всъхъ сторонъ собрались медики и занялись отнятіемъ его ноги, а Рарокъ оставался безъ мальйшей помощи. Я вельъљ его 
полка гренадеращъ положить его на плащъ и отнесъ его въ Поповку, въ господскій домъ, тутъ находившійся, куда посль операпіи и графа перенесли. Такъ какъ не скоро сдълана была операція и много вытекло крови, то Рарокъ на другой день и ущеръ.

При графь оставленъ быль батальонъ егерей, а войска и всь волонтеры выступили, и на другой же день подъ Ћобылюою присоединились къ арміи графа Суворова, въ соединеніи и бывшаго корпуса Ферзена, гдъ я имъль чрезвычайное удовольствіе прибыть къ своему полку, который былъ подъ начальствомъ прикомандированнаго подполковника Бибикова ${ }^{216}$ ).

Нельвя умолчать случая, который послужить можетъ прим'љромъ не бояться смерти, и что она находитъ свою жертву не тамъ, гдь ея ожидають. Одинъ литляндскій 4-й егерскій батальонъ командуемъ быль подполковникомъ Шпарманомъ, человъьомъ пожилымъ, небогатымъ, женатымъ и обремененнымъ большою семьей. Во время нашего похода онъ говорилъ, что такъ какъ онъ пойдетъ посль кампаніи въ отставку, то и не желаеть рисковать своею жизнію, что ежели бы кто захоть⿻ыь принять его батальонъ снисходительно, то онь радъ бы его быль сдать, чтобы самому выпроситься въ отпускъ, впредь до отставки. Графъ Зубовъ былъ ко мнь благосклоненъ и объщаль мнг доставить тотъ батальонъ, и у насъ съ Шпарманомъ почти сдъ̌лано было условіе. Но такъ гакъ онъ съ симъ батальономъ оставался при графь и не подвергался опасности, то онъ пнъ и отказаль въ сдачъ. Я быль на прагскомъ штурмъ, остался здоровъ, а онъ занемогъ горячкою и черезъ ньсколько дней умеръ.

(216) Александръ Александровичъ Бибиковъ, сенаторъ, род. 1765 г., ум. 1829 г., второй сынъ знаменитаго дййствіями противъ Пугачева Алегсандра Ильича Бибикова, командовавшій въ 1812 году с.-петербургскимъ онолченіещъ. $\boldsymbol{M}$. JI. 
22-го огтября подошли мы къ предмъъетію Праги, угръпленному крйыкимъ ретраншаментомъ, запятымъ 30 тыстчами человйгт польскаго войсба; но онъ былъ тағъ обширенъ, тто, чтобы хоропо ошый защитгить, по крайней мйръ надобно было быть сильнһ̆е втрье. Бъ ту же ночь валожено было нйскольғо батарей, и длл прикрытія оныхъ дожементъ. 23-го числа канонировали ретраншанешт'ъ, на что́ нам'ъ отвйчали, -без̆ъ большаго вреп̆а съ об̆ыихт сторонт.

Слабая сторона ретраншамепта праваго фланга была со стороны Вислы, для чего между сего рйюой и болотомъ,

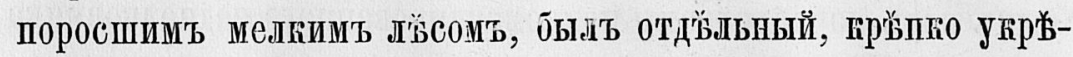
пленный ретраншамегтъ, верстахъ въ двухъ отъ главнаго, подъ начальствоиъ полговника Лблоновскаго. $\mathfrak{K}_{6}$ ветеру того дня, генералъ-щгйоръ Пенисовъ съ 7-іо колонной, назначенгою дыл штурма, подучиль повелььніе обойдти то болот0 и остановитьсп далъе пушечнаго выстрйыа, и чтобъ онъ, по общимъ сигналамъ для прочихъ 6-ти колоннъ,

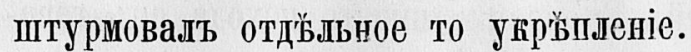

Мы подошли въ сумерки и остановились въ колоннъ. Во время нашего марша, съ другой стороны Вислы, по насъ стрйляли ивъ пушекъ без'ъ малйййшаго вреда.

Со мною былъ странный случай, подавшій поводъ к'ъ разнымъ догадкамъ. Ночь была холодная и небольшой морозъ; легли мы нъссколько соснуть и прикрылись соломою, которую нашли въ близь-находившемсп хуторь. Поляви, усмотря насъ, во всю ночь стрйынли свь̆тлыми ядрами, чтобы не быть въ расплохъ атағованными. Јишьь тольго я задремал'ъ, какъ вдругъ почувствовалт, что кто-то меня ударилъ по ляшाв; я думалъ, что со мною хотйлъ пошутить майоръ Арсеньевъ, и я ему сказалъ: “Полно, братъ, шалить, я был0 заснулъ.» Онъ говоритъ: «Јежи смирно, возльъ теб̆я упала бомбоа.» А какъ нйсколько времени прошґо, бомба не разразилась и отъ трубки солома не загоржылась, то я къ ляшкъ̌ протянулъ руку и ощушаль карғасъ. Надобно 
было думать, что уже онъ, вовсе потерявъ силу, подғатился к0 мнб и остановился; но въроятнъе, что глыба земли, въ которую онъ ударился, отбрызгнула и ударила меня.

По сдъъланной диспозиціи, по первой сигнальной ракеть войска должны были сформироваться въ колонны, по второй идти къ назначеннымъ пунктамъ и остановиться на пушечный выстрьљљ, по третьей штурмовать. Первый сигналъ, видно, мы просмотрълл; по второму встали, а по третьему тронулись, но уже услышали крикъ штурма и открывшійся огонь; почему въ ретраншаментъз противу насъ Поляки, будучи предупреждены, встрьтили насъ изъ всъхъ дефензій сильнымъ картечнымъ и ружейнымъ огнемъ, такъ что голова ґолонны остановилась на нъскколько минутъ. Но Денисовъ вель̌лъ принять вльво по болоту, и пы по поясъ въ водъ вошли въ ретраншаментъ, поражая бъгущихъ къ Прагъ, куда мы вошли уже въ порядкъ. Тамъ мы нашли всъхъ въ разбродъ̌ и на грабеж苂. Вскор๘ поставлены были батареи по берегу Вислы и открыли канонаду по Варшавґ; мостъ Поляки успьљли разобрать.

Чтобы вообразить картину ужаса штурма по окончаніи онаго, надобно быть очевиднымъ свидъ̌телемъ. До самой Вислы на всякощъ шагу видны были всякаго званія умерщвленные, а на берегу оной навалены были груды тылль, убитыхъ и умирающихъ: воиновъ, жителей, Жидовъ, монаховъ, женщинъ и ребятъ. При видъ всего того сердце человь̌ка замираеть, а взоры мерзятся таковымъ позорищемъ. Во время сраженія, человъ̌къ не только не приходитъ въ сожал出ніе, но остервеняется; а посль убійство дъ̆лается отвратительно.

Ввечеру, оставя часть войска охранять Прагу, мы возвратились въ лагерь. Поляюи потеряли на валахъ 13 тысячъ уеловЊкъ, ихъ которыхъ третья часть была цвъ̆ть юношества варшавскаго; болье двухъ тысячъ утонуло въ Висль; оголо 800 человъьк ивъ гарнизона уцйльљ, перешедши 


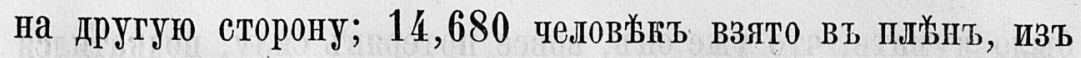
числа которыхъ восемь тысячь на другой день отпущены въ домы; умерщвленныхъ жителей было несчетно. Русскіе потеряли 580 человъьь убитыми и 960 раненыхъ; пушекь и мортирь взято въ ретраншамент'ъ 104.

2つ-го октября присланы были изъ Варшавы'депутаты съ письмомъ оть короля, которые представлены были графу Суворову. Побъдитель сидъљљ въ палаткъ, разбитой на

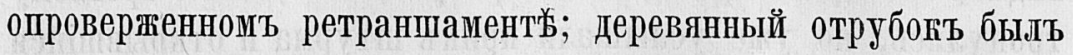
вмбесто стула, а другой, повыше, виъсто стола. Графъ, какъ скоро увидъљљ ихъ, бросиль свою саблю и сказаль: «иръ, тишина и спокойствіе». Обняль пословъ, послы обнимали его кольна и спрашивали: на какихъ угодно будеть пунктахъ графу предписать капитуляцію польской столицй, повергающейся юъ освященнымь стопамъ Россійской монархини? Побьдитель отвъчаль: «Жизнь, собственность, забвеніе прошедшаго, и моя государыня даруеть мирь и спокойствіе». Послы, изумившись, возвратились въ Варшаву, ожидавшую ихъ съ трепетощъ. Они, еще не доъзжая берега, кричали: «Повой! Покой»! Народъ въ восхищеніи бросился въ воду и вынесъ ихъ на рукахь; въ радостныхъ крикахъ провожали ихъ въ Раду. “Виватъ императрица, виватъ Суворовъ)! - по всей Варшавьь слышны были такіе клики.

Въ сію ночь въ Варшавж произошло волненіе; мятежники намъревались всльдъ выступивпимъ войскамъ насильно увезти короля и всъхъ россійскихъ военно-пльнныхъ; но народъ до того не допустиль. Колонтай, похитя казну, въ ту же ночь скрылся.

Графъ Суворовъ, извьстясь, что польскія войска не х0тьели сдаться и выступили къ Кракову, вельљьь Денисову съ его колонною идти вверхъ по Висль, переправиться черезъ оную у Гуры въ бродъ и пресльдовать оныя. 0 походъь ономь сказано будеть посль, а теперь скажу о вступленіи напихъ войскъ въ Варшаву. 
Генералъ-майору Буксгевдену ${ }^{217}$ ) приказано починить мость.

27-го октября прибыль польскій подшолковникъ ГоФшанъ, съ прошеніемъ осьмидневнаго срока на размышленіе. Суворовъ отвъчалъ: “Ни минуты»! Черезъ часъ присланы Потоцкій и графь Мостовскій съ письмомъ отъ короля, уполномочивавшаго начать переговоры 0 миръ. Побъдитель сказаль: «Съ Польшею у насъ войны ньтт, я не министръ, но военачальникъ: сөкрушаю толшы мятежниковъ». Того же дня съ донесеніемъ императрицъ о взятіи Варшавы посланъ былъ подполковникъ Бибиковъ.

29-г0, въ девять часовъ утра, войска наши вступили въ Варшаву съ распущенными знаменами, барабаннымъ боемъ и музыкою; графъ Суворовь ьхаль въ простомъ мундиръ. Какъ скоро побъдитель съъхаль сь мосту, на самомъ берегу встръченъ быль магистратощъ, гупечествомъ и мъњанами, съ хльбонь и солью, и ему поднесли городскіе ключи. Графъ Суворовъ приняль ихъ, поцвооваль и сказаль: «Хорошо, что они дешевле достались, нежели тьь», погазавъ на Прагу. Улицы, по которынъ проходили поб̆ддители, усыпаны были народомъ, восклицавшичъ: «Виватъ Екатерина!) Вивать Суворовъ!

У назначенной для графа Суворова қвартиры ожидали его россійскіе пльнные, генераль-майорь Милашевичь и генералъ-майоръ Арсеньевъ (потораго потомъ наименоваль онъ дежурнымъ генераломъ), 1376 человъ̌к нижнихъ чиновъ, 500 Прусаковъ и 80 Австрійцевъ.

На другой день графъ Суворовъ посььтијъ короля, а черезь два дня польское величество назначил'ь, что пріњдетъ кь нему. Графь приказалъ дежурному генералу написать церемоніяль, каґъ принимать короля, въ которощъ сказано

217) Грабъ Өедоръ Өедоровичъ Буксгевценъ, генералъ отъ инФантеріи, род. 3 сентября 1750 г., уг. 11 августа 1811 г. M. JI. 
был0: «Графскіе адъютанты встрьтятъ его у гареты, дежурный генераль у ли̌стницы, а графу должно встрьтить его передъ пріемною комнатой). Но лишь только сказали, что король вдеть, граФъ Суворовъ безь шпаги и шляпы оросился встрбчать къ кареть্ и сталь было гороля принимать подъ руки; но, остановясь, сказаль: «Погодите, погодите; въ̆дь, Николай Дмитричь, по церемоніялу не туть я долженъ принять его величеств0; простите меня: я такъ почитаю освященную особу вашего величества, что и забылся». Оставя короля, онъ побъъжаль въ домъ и приняль его уже передъ пріемною.

Пресль'дованіе Поляковъ, ушедшихъ ивъ Варшавы, болье похоже было на тріумфальное шествіе, чь̆мъ на походъ; войска были во всещъ изобиліи. Въ началь они встрьчали толпами Поляковъ, не хотьвшихъ сль̈довать ихъ главному начальнику Вавржецкому; потощъ цъылые эскадроны и батальоны клали оружіе, и находили оставленныя пушки. Въ нъстечкъ̌ 0почнё ғазағи нашли 22 пушки съ ихъ зарядными фурами и около трехъ тысячъ ружей, и донеся 0 томъ генералу, отправились пресльздовать далье. Какъ оылъ прямъйшій тракть догнать бъгущихъ, то Денисовъ отправился по оному, а взять сказанную артиллерію въ мйстечк'ь 0почнъ Денисовъ отрядилъ полковника Вольфа съ Елисаветградскижъ конно-егерскимъ и Козловскимъ пъхотнымъ полками и батальономъ егерей. Пришедъ туда, нашли тамъ прусскаго майора Кроха, съ отрядомъ въ 800 человЊ̌къ, приставившаго караулъ къ сказаннымъ орудіямъ. 0нъ, бывши въ недальнемъ разстояніи, узналь черезъ своихъ лазутчиковъ, что Поляки оставили въ 0почнъ упомянутыя орудія и, пришедъ туда, когда казаковъ тамъ уже не было, оныя присвоилъ себъ. Полюовникъ Вольфъ, прибывъ съ своимъ отрядомъ въ Опочню, требовалъ отъ прусскаго майора, чтобъ онъ тй орудія отдалъ нашъ, какъ взятыя нашими казаками. Майоръ Крохъ отвьччалъ, что, «когда онъ при- 
былъ въ Опочню, ни одного казака тамъ не нашель и, по военному праву, взявъ оныя орудія въ свое вйдънніе, рапортоваль 0 томъ королю, а затьим отдать ихъ уже не можетъ». Вольфь донесъ о томъ Денисову, который прислаль ордеръ: «вяять). Вольфъ показываетъ своего генерала ордеръ майору Ћроху; но тотъ сказаль, что “отрядъ его малосиленъ, а Русскихъ болье вчетверо, сльдственно вы можете взять, но только вооруженною рукой и какъ непріятель, но добровольно я вамъ пушекъ не отдамъ». Вольфъ опять донесъ о семъ отвйтй, и что онъ взять силою не осмь̆ливается, безъ точнаго на то повельнія. Денисовъ, думая, что Ћаменскій, подполковникь егерскаго батальона, скоръе исполнитъ его волю, поручиль ещу исполнить т0, а Вольфа съ конно-егерскимъ полкомь потребовалъ къ себъ. Крохъ ґъ Каменскому идти не захотьљљ, а тотъ употребиль меня, чтобъ уговорить упрямаго прусскаго майора. Хотя я на свое красноръчіе не надъ̆ллсп, но долженъ быль исполнить приказаніе. Ћрохъ мнъ -сказалъ: “Посудите сами: еслибы вы были на моемъ м'зсть́ и отрапортовали своему начальству, то могли ли бы отдать безъ повельнія онаго»? Возразить было нечего, и тогда онъ мнъ показаль письмо, полученное имъ оть Денисова, сочиненное по-Французски извъстнымъ Копьевымъ ${ }^{218}$ ), тағимъ вздоромъ наполненное, что мнъ было стыдно, которое онъ въ оригиналь отправиль къ королю. Между прочимъ было въ ономъ написано, что «видно Прусакань диковинка брать пушки, а Русскимь не въ диковинку, даже ими и не уважаютъ», и проч... Спорь о сихъ пушкахъ доходиль до короля и графа Суворова, и уже гораздо посль' о томъ ржшено. Когда сія распря 0 пушкахъ происходила, въ мыстечкь Вартахъ Вавржецкій быль окруженъ и принужденъ быль сдаться со всъми генералами и

218 Алегсьй Даниловичъ Копьевъ, авторъ извъстной комедіи лебедянская армарка. (Спб. 1794 г.) M. JI. 
войсками, которыхъ тотчасъ обезоружили. Посль̆ сего вся армія заняла зимовыя квартиры; Ћовловскому полку назначены онъ были за 18 миль отъ Варшавы по праву! сторону Вислы.

За взятіе Варшавы, графъ Суворовъ пожалованъ фельдмаршаломъ, и присланъ быль ему повелительный жезль ${ }^{219}$ ); многіе награждены были орденами и золотыми шпагами за храбрость, въ числьь которыхъ и я удостоился получить шпагу; многіе произведены въ сльвдующіе чины; въ томъ числьв и я, по рекомендаціи, за многія дъзла, въ которыхъ я былъ во время польской экспедиціи, пожалованъ подполковникомъ, посль семильътней моей службы въ премьер'ьмайорскомъ чинъ̆; всъ штабъ и оберъ-0фицеры награждены золотыми грестами на георгіевской ленть̈ въ петлицу, съ надписью, съ одной стороны: $з а$ труды и храбрость, а съ другой: Прага взята 1794 года 24 октября. Солдаты получили медали.

Козловскій польъ получиль повельніе придти въ Варшаву и помъщенъ быль въ казармахъ близь Јазенокъ, загороднаго горолевскаго дворца.

Впервые мнъ случилось быть подъ начальствомъ великаго полководща, графа Суворова. Онъ быль тонгій политикъ и подъ видомъ добродушія быль придворный человъ̌къ;

219) Суворовъ донесъ Екатеринъ о взятіи Варшавы тремя словами: (Ура! Варшава наша!) Екатерина отвь̆чала 19 ноября двумя словами: «Ура! фельдмаршалъ!) Кромъ жезла съ брилліантами, Екатерина пожаловала ему 7000 душъ, пмператоръ Австрійскій свой портретъ, а король Прусскій ленты чернаго и краснаго орла. Екатерина написала ему: “Вы знаете, что я не произвожу никого черезъ очередь... но вы, завоевавъ Польшу, сами себя сдъзлали фельдмаршалом'ъ). Дъйствительно Суворовъ обошель девять генералъ-аншефовъ: графа И. II. Солтығова, графа Н. И. Солтыкова, князя Н. В. Репнина, княвя ю0. В. Долгоругова, графа И. К. Эльмта, князя А. А. Прозоровскаго, графа В. П. Мусина-Пушкина, М. $\theta$. Каменскаго и М. В. Каховскаго. 
передъ всъим показывалъ себя страннымъ, оригиналомъ, чтобы не имъть завистниковъ; когда съ къмъ надобно было объясниться наединъ, то сказывали, что онъ говорилъ съ убъдительнымъ краснорфчіемъ; сужденія его были основательны, а предпріятія чрезвычайно дальновидны, что́ опытъ доказалъ. Вырвались у него сказанныя моему пріятелю слова, показывающія правило, котораго онъ держался: “Pour parvenir, mon ami, il faut avoir la patience d'un cocu». (צтобь достилнуть, надобно быть терпльливу, какб рогоносеи $\left.{ }^{220}\right)$. Но какъ скоро онъ былъ втроемъ, то и принималь на себя блажь. Совершенно зналь языки: французскій, нъмецкій, латинскій, греческій и турецкій. Въ угожденіе ему надобно было юъ его странностямт привыкнуть, не говорить: «не могу знать», “не могу доложить», даже и “не знаю». 0 всъхъ таковыхъ онъ говаривалъ: «Боже упаси отъ немогузнаекъ; отъ нихъ бъда; надобно все знать». Напримъръ, вдругъ спросить кого: “Что́ султанъ ды̆лаетъ»? надобно соврать что́ хочешь, только не говорить: "не знаю»; или напринърь: “Далеко ли отъ Варшавы до Праги»? скажи: “250 версть, 13 саженъ и 1 аршинъ), то онъ и доволенъ и говоритъ: “Вотъ настоящій человъкъ: все знаеть".

Военныя его дъйствія всегда располагаемы были такъ, чтобы дыйствовали на мораль людей, каґъ на своихъ, такъ и на непріятелей. Визирь шель атақовать принца Кобургскаго и върныя имьљль извъстія, что Суворовъ былъ еще накануне въ Берлать', верстахъ оголо ста оть принца. Какъ вдругъ виъсто Цесарцевъ увидъль онъ себя атакуемаго Русскими; изумленіе было болъе причиною побъды, чйчь самая храо̆рость. Равно и разоитіе трехъ польскихъ корпусовъ. Поляки о самомальйшихъ нашихъ движеніяхъ имъьли скорыя и върныя извъстія; о Суворовь же и эхо

${ }^{220}$ ) Въ әтихъ словахъ намеќь на собственную судьоу Суворова. $П$. . 


\section{$-184-$}

не касалось до ихъ слуха; ожидали отъ Русскихъ нападенія съ лица, вдругъ Суворовъ, какъ съ неба упалъ, поразиль ихъ при Кобринъ и, не давъ имъ образумиться, при Бресть⿱丶万 и Крупиць. Хотя много оставляль онъ за собою усталыхь, которые приходили на другой день или на третій, даже и позднъе, но скорыми своими маршами и внезапностію всегда побьждаль. Генералы и военные съ дарованіемь люди долго думали и приписывали всъ̌ дъ̌兀ла его счастію; но уже въ италіянскую кампанію увиджли въ немъ генія въ военномъ искусствъ, и что всъ баталіи, имъ выигранныя, и ни одна не проигранная, были обдуманы человь̌юоъ, котораго никто постигнуть не могъ.

Суворовъ окружаль себя людьми простыми, которые бы менье всъхъ могли отгадать его; однакожъ отъ нихъ зависъла участь служащихъ подъ начальствомъ графа Суворова. Чтобы получить какое награжденіе за настоящую службу, надобно было съ низостію искать тёхъ покровительства; таковы были при немь ћурисъ, Мандрыкинъ, и прочіе.... Ћто в'ь нихъ не снискаль, не только не успьваль по службъ, но иногда обращаль на себя неудовольствіе графа, и самъ онъ своею странностію иногда унижаль людей достойныхъ. Во время прагскаго штурма онъ закричалъ: «И я возьму ружье со штыкомъ.»-«Нуть, ваше сіятельство, не пустимь васъ», говорили знавшіе его; кто хваталь за узду его пошади, кто хваталь его за руку и полы платья, когда онъ и шагу не намьренъ быль сдъљлать; но онъ дълаль видъ будто вырывался, и кричалъ: «Трусы, трусы, пустите меня!» Только что выпущенный изъ кадетскаго корпуса поручикъ Оленинъ какъ-то попался къ нему въ свиту, и по простоть своей, думая сдьљлать ему угодное, сказаль: «Иввольте, ваше сіятельство, я васъ проведу на возвышенное мысто, откуда вы изволите усмотрьть весь штурмъ». Графъ его расцьљловалъ: «Воть одинъ только герой, а вы всґ трусы», сказаль онъ. Однакожъ и затьумъ 
т占 его не пустили. Что́ же? Всъ тй, которые его не пускали, были награждены, а 0ленинъ остался безъ ничего и отпущенъ въ полљъ. Во время сраженія Суворовъ всегда бываль на казачьей лошади и на казачьемъ сьддль', дызлаль видъ, что скакаль въ пылъ сраженія, но каґъ скоро зам'ччалъ, что нигто его не удерживаетъ, останавливался, сльъзаль съ лошади и переправляль свою обувь, говоря: «0хъ, онуча жиетъ ногу». (Онъ, вмъсто чулокъ, обертывалъ ноги тонкимъ полотномъ, на подобіе онучъ).

Спаль онъ всегда на съ̌нъ, покрытомъ простынею; другой постели во всю жизнь не имъљъ; всякій день обливался холодною водой, несмотря ни на какую погоду; столь его быль простой, но сытный; въ постные дни никогда не Блъ онъ скоромнаго; никогда не заботился, чтоे будетъ ьсть; этимъ занимался Курисъ. Часъ объда Суворова, когда захотьыљ; иногда въ 8 часовъ утра, но не позже 11. Говорили, что онъ любить пить, но это неправда; передъ объдомъ онъ выпивалъ большую рюмку водки, а за столощъ рюмки двъ̌ вина; если же иногда наливалъ третью, то Тимченко, его ғамердинеръ, ему запрещалъ, равно еслибы сверхғ обынновеннаго хотыль съъсть лишнее; «ну, Тимченко не велитъ, говориль онъ, надобно слушаться».

По прибытіи моешъ въ Варшаву, я долженъ былъ явиться къ нему съ рапортощъ. Чтобы сдъљать ему угодное, по наслышкъ, изготовился я отвъьчать на всъ его странныя требованія; но вмёсто того обратиль на себя его негодованіе, за что, не знаю, и получиль за столомъ чувствительный афронтъ. Думаю, что подалъ къ тому поводъ слььдующій случай: сержанть гвардіи передъ объдомъ разносилъ водку по старшинству чиновъ; ежели кто были въ однихъ чинахъ, то тотъ сержантъ спрапивалъ, съ котораго года и мисяца состоять въ оныхъ; почену и меня спросилъ, какъ человька новаго и впервые бывшаго у графа. I сказаль, что уже 6 льить, 3 мьсяца и 12 дней въ семь чинъ, 


\section{$-186-$}

и усмххнулся. Казалось, что графъ сего не могь примьтить, но другой причины къ его неудовольствію не было. Сьли за столь; мнь пришлось сььсть наискось противъ графа. Вдругъ онъ вскочиль и закричаль: «воняеть!) и ушель въ другую ћомнату. Адъютанты его начали открывать окошки и сказали ему, что “дурной запахъ прошелъ). - «Нъ̆ть, кричаль онь, за столомь вонючка». Они стали обходить веъхъ сидящихъ и начали обнюхивать; одинъ, ко мнь подошедъ, сказаль: «Вњрно у васъ сапоги не чисты, иввольте выйдти; графъ не войдеть, пока вы не встанете и не прикажите себбъ сапоги вычистить; тогда опять можете сьсть за столь». Представьте мое смущеніе; однакожь дьљлать было нечего. Я всталь, сказаль тому адъютанту: «Доложите графу: я вижу, что моя физіономія ему не понравилась; какъ бы мнге пріятно ни было обратить на себя благосклонное его вниманіе, но я къ нему болье не явлюсь»и вышель. Посудите, пріятно ли было служить при немь человъку съ благороднымь чувствомъ? Признаюсь, что, несмотря на его великій геній, и служа подъ нимъ въ его славныхъ побъдахъ, пріобрьтая чины и ордена, трудно перенесть подобныя оскорбленія, готорыя не съ однимъ со мною случались, но и сь нькоторыми генералами.

Варшава для меня была фатальна. Прибылъ я съ полкомь 15 декабря и привезь съ собою экономическаго провіянта почти на цијлый мбсяць, но отъ казны удовольствованъ былъ по 17-е число. Тогда случилось, что подполковникъ Ржевскій, командирь одного егерскаго батальона, не имъљљь болье провіянта, да и въ магазинахъ также его не было. Для сего батальона оть разныхъ полков'ь собирали провіянть для ежедневнаго продовольствія. Генераль-поручикъ Ферзенъ, командующій войсками, расположенными въ Варшавъ, отдалъ приказь: что ежели полковые и батальонные командиры узнаютъ, что въ магазинахъ провіянта ньть, то заранъе оы доносили, по которое время провіянть у нихь кончится, 
въ противномъ случаж таковые нерадивые начальники будутъ отвъьчать передъ военнымъ судомъ. И какъ тоть день уже было 17-е число, то я и рапортовалъ, что Козловскій полкъ провіянта не имъетъ, да и въ магазинь̆, по справкъ моей, не имжется. Рапортъ, отправленный мною того же дня кь бригадному командиру, генералъ-майору Буксгевдену, продежаль у него въ ғанцеляріи болье сутоюъ, почему Ферзенъ получилъ оный уже чрезъ два дня. 0нъ тотчасъ побхаль къ фельдмаршалу графу Суворову доложить, что оберъ-провіянтмейстеръ Сль̆ушшкинъ ложно увъриль графа, тто всъ полки удовольствованы по 22-е число, а полюъ Козловскій уже два дни безъ провіянта. Графъ сказалъ: “Помилуй Богъ, не хорошо, Сль̆пушкинъ за ложь будеть солдатъ . Все сіе происшествіе узналь я уже пाос.I'.

Я легъ спать, какъ вдругъ ночью слышу, что меня будятъ; просынаюсь и вижу у моей постели на кольняях стоящаго штабъ-офицера. Я удивился и спрашиваю: гто онъ и чего отъ меня хочетъ? «Я оберъ-провіянтмейстеръ Сль̆пушкинъ; отъ васъ зависитъ, чтобъ я завтра же быль солдатъ, или остался въ своемъ званіи».-Кағъ это? «Вы рапортовали, что полюъ снабженъ провіянтонъ только по 17-е число, и фельдмаршалъ мнь⿻ объявиль, что ежели я ему отъ полка не представ.п промеморію, что онъ удовольствованъ по 22-е число, то поклялся, что онъ никогда еще никого не сдызлаль несчастнымъ, но меня разжалуеть въ солдаты.»-Что́ жь мнґ дъълать? «Я привевъ провіянтъ; прикажите принять и дать мнъ въ пріеше квитанцію). Какъ долженъ я быль поступить? Если я ему въ томъ откажу, я буду причиной несчастія человъъка; ежели исполню его просьбу, то сдъълаю чувствительньйшее неудовольствіе генералу Ферзену, всъ̌ми уважаемому, и котораго я душевно почиталъ. Однакожъ я ръшшился огорчить Ферзена и не сдъљать несчастнымь человъка, мнъ незнакомаго, и ко- 
тораго по репутаціи зналь даже за человь̌ка, не имъюющаго честныхъ правилъ.

Я вельль - разбудить квартермистра и ротныхъ пріемщиковъ, приказаль принять провіянть по 22-е число и раздать въ роты, что́ и было исполнено. Написалъ рапортъ, что посль подданнаго оть 17-го числа моего рапорта полкъ удовольствованъ провіянтомъ по 22-е число, поставя на рапор'ге 19-е число, и отправиль тоть же часъ въ бригадное дежурств0, а т究ь же числомь Сльпушкину даль въ пріемг квитанцію; на спросъ же его бумагою: по которое число удовольствованъ польъ провіянтомъ? даль промеморію уже 20 числомъ.

Сль̌нпушкинъ какъ скоро быль допущенъ къ фельдмаршалу, то и представиль данную мною ему промеморію. Графъ послаль дежурнаго генерала Арсеньева показать оную Ферзену и сказать: «Не хорошо обижать Нъмцамь Русскихъ». Ферзенъ, до потораго посльдній мой рапорть еще не дошель, чрезвычайно мною быль раздраженъ; тотчасъ написаль онъ къ фельдмаршалу рапорть съ требованіемъ, чтобъ я былъ шреданъ военному суду за ложное донесеніе.

Ћъ счастію моегу, того же числа наряженъ я быль считать экстраординарную сумму съ двумя другими штабъофицерами. I явился въ канцелярію въ 11 часовъ; правитель канцеляріи, г. Мандрыкинъ, вручая мнге книгу и ордера, сказаль: “Извольте поспьшить счетомъ и представить сегодня въ 9 часов' вечера; графу нужно сего же дня отчетъ отправить». Сумма была слишкомь 丂0 тысячь червонцевъ; я говориль, что въ такое короткое время счесть невозможно, но Мандрыкинъ съ грознымъ видомъ сказаль: «Я не знаю, можно ли или не можно, но я вамъ объявляю графское приказаніе, впрочемъ это ваше дъ̌ло; какъ вы хотите, только знайте, что уже и гурьерь къ отправленію готовъ, а графъ отговорокъ не любитъ».

Нечего было дылать; съ собравшимися моими товарищами 
принялись мы считать. Суммы выдаваемы были большимъ числомь, большею частію шпіонамъ; два ордера были не подписаны, на 150 червонщевъ; я показалъ ихъ Мандрыкину, сказавъ, что счетная комииссія принять ихъ не можетъ. Мандрыкинъ сказалъ: «Графъ ихъ посль подшишетъ, извольте считать.) A предложиль своимъ товарищаиъ, которые не хотьли брать на свою отвьтственность, но я ихъ увъриль, что ежели будетъ взысканіе, то я за сію сумму отвъัчаю, на что они и согласились. И таґъ мы успьли кончить счеты, подвести итоги и сдйлать счетную выписку, которую, при рапорть́ графу, принесъ я къ Мандрыкину въ назначенный сроґъ. Онъ просилъ меня подождать, пошель къ его сіятельству, и вынеся отъ него, показалъ ннь подписанные тъ̌ ордера, готорые даны были мнъ̌ безъ подписи.

Мандрыкинъ предложиль мнъ свои услуги, а как’ я благодариль за его к0 мнъ доброхотство, сказавъ, что на сей разъ я не имъюю никакой нужды, онъ возразилъ: «Полно, не могу ли теперь же я вамъ услужить?) И тогда показалъ мнъ рапорть Ферзена, требовавшаго меня судить военнымъ судомъ. Хотя я передъ судомъ и былъ бы оправданъ, ибо дъйствительно полкъ удовольствованъ быль по 22-е число, и рапортъ мой 0 тощъ посланъ быль еще 19-го числа, дошедши до рукъ Ферзена чрезъ два дня посль⿱⺊口灬, но не мен库 того больно бы было быть подъ судомъ, что́, по обыкновенію, вносилось въ послужной списокъ. И такъ я чрезвычайно симъ огорчился. Мандрыкинъ, видя мое спущеніе, сказаль: «Не безпокойтесь; графъ никогда этотъ рапортъ не увидитъ, и мы его ускромимб) (слово, употребляемое графомъ), и тогда же его разодралъ.

Ежели съ такимъ извъстнымъ и заслуженнымъ генераломъ могли такъ поступать управляющіе канцеляріею, то какой справедливости должны были ожидать низшіе классы подчиненныхъ? Потомъ Мандрыкинъ спросилъ меня: «Кажет- 
ся, вы просились въ отпускъ? Скоро ли вы хотите жхать?»Я бы тоть же часъ убхаль, какъ скоро получу паспортъ. «Погодите немного». Онъ пошель въ кабинеть Фельдмарпгала и вынесь оть него мой отпускь. Получа оный, пріьхаяъ я въ казармы (сдавать мнге было нечего, ибо полґомъ командоваль я по наружности, потому что полковникъ мой, за отсутствіемъ моимъ, сдаль полюъ по полюовничьей инструкціи майору Арсеньеву), и собравшись, уь̌халь.

Дорогою объ'ьхаль я короля Станислава-Августа, котораго везли въ Гродну, гдь ожидаль его князь Н. В. Репнинъ. И такъ императрица возвела его на престоль польскій, и она же лишила его короны.

Посль' сего Польша была раздъллена: Россія получила всю Литву по Нъманъ и западный Бугъ, а черезъ ньсколько мьсяцевъ Курляндское герцогство поддалось добровольно. Пруссія присвоила Варшаву и всь' земли, смежныя съ ея владъніемъ, съ кржпостями Данцигомъ и Торунью. Австрія получила земли, смежныя съ ея Галиціею, по западный

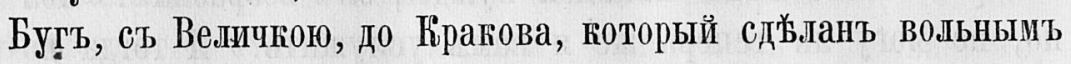
городон' .

Приоывъ къ отцу моему, узналь я, что знть мой, С. К. Вязмитиновъ, сдъланъ быль генераль-губернаторощъ УФимской и Симбирской губерній и командиромт Оренбургскаго корпуса. Онь уговориль мені перейдти подъ его начальств0, чтобы быть вмьсть съ моею сестрой. Почену въ 1795 году дань мнбь быль третій Оренбургскій полевой батальонъ, и такъ я перенъстился въ столь отдаленный край.

Въ сещъ году открылась персидская война, продолжавшаяся до восшествія на престоль государя ииператора Павла I, подъ главнымъ начальствощъ генераль-поручика графа В. А. Зубова. Успьхомъ сей войны было взятіе Дербента. 1796. Въ 1796 году въ августь было избраніе и утвержденіе, вмъсто умершаго, новаго Киргизскаго меньшой орды хана. Обрядъ сей происходиль сль̌дующимъ образомъ: 
между Оренбурга и мйноваго двора, за Уралочъ построеннаго въ трехъ верстахъ отъ кръпости, Киргизы собрались въ ньсколько тысячъ кибитокъ, разныхъ ихъ родовъ, управляемыхъ своими султанами: Когда за Ураломъ поставлены были собранныя войска Оренбургскаго корпуса, тогда генералъ-губернаторъ послаль тому народу сказать, чтобъ онъ приступиль, по обычаю своену, къ избранію хана, уже заблаговременно назначеннаго нашимъ правительствомъ. По нёкоторощь преніи, избраніе гончилось. Хана нарядили въ богатую парчевую, чернобурыхъ лисицъ, шубу и такую же шапку, присланную въ даръ отъ двора; Киргизы, посадя его на кошму, подняли на руки и начали качать съ превеликимъ крикомъ, на что отвәттстовано было въ честь хана пальбою изъ крђнпости и состонвшей при полкахъ артиллеріи, и ружейнымъ бжглымъ огнеиъ. Посль чего ханъ былъ угощаемъ съ султанами объденнымъ столощъ у генералъ-губернатора, а всъ прочіе Киргизы - на степи близь нашихъ войскъ, поторыхъ угощеніе состояло во множествъь изготовленнаго ихъ кушанья, пли по ихнему бишъ-бармака, то-есть, изрубленной мелко баранины съ лукомъ и бараньимъ саломъ, пловомъ и ғумысомъ. Киргизы хватали ғушанье, какъ голодные волки; у каждаго былъ приготовленъ гожаный мъшокъ, висььвій на шеъ; они, выжавъ рукою жиръ и жижу въ ротъ, оставшееся въ рук'̌ въ запасъ клали въ сіи ғожаные мйшки. Ть̈иъ ғончился весь праздникъ; на другой же день Киргизы откочевали во внутрь степи.

\section{V. Царствованіе Павла I.}

Внезапная смерть императрицы Екатерины II Алексъевны облекла Россію въ сердечный трауръ. Она воспосльдорвала въ 1796 году 6 ноября, на шестьдесять седьмомъ году, шестомъ мвсящь и четвертомъ днб ея рожденія; цар- 
ствованія же ея тридцать четыре года, три мъсяща и двадцать семь дней. Сперть ея поразпла вообще всьхъ, и каждый пумаль, что лишился въ ней нъ̌жной матери.

Въ ея царствованіе Россія была славна и счатлива, подданные ея наслаждались спокойствіемъ, ғаждый гражданинъ увъренъ былъ въ безопасности личной и обладаніи своей сөбственности. Она отказанась отъ наиченованія, поднесеннаго ей сенатощъ: Великой и премудрой матери отечества. Но все то помня, сыны отечества сохранять навсегда въ сердщахъ своихъ сію дань справедливаго титла. Она сдьлала многія учрежденія къ управленію Россіи, способствовавшія къ утвержденію благоустройства и скорому теченію дъљљ. Она основала и пріобрьла до 250 городовъ, торговля въ ея царствованіе распространилась по всьнь морямъ, доходы государства, прежде бывшіе не свыше з丂 милліоновъ рублей, безъ наложенія новыхъ податей, знатно умножены; морская и сухопутная силы Россіи въ ея время приводили въ ужасъ всю Европу: Въ награжденіе за военные подвиги она учредила орденъ Св. Георгія, а для гражданскихъ чиновъ Св. Владиміра. Покровительствовала науки и художества, и привела юъ концу то, что́ Великій Петрь предпринималь. 0 всьхх ея дейлахъ вкратць сказать нь̌ттъ возможности. Ћонецъ ея царствованія былъ слабъе; она дала много воли графамъ Зубовымъ. Сқоль ни славно царствованіе Екатерины Великой, но спокойствіе не разъ было нарушаемо: 1) Возмущеніе Мировича, желавшаго освободить императора Іоанна Антоновича ${ }^{221}$ ), содержимаго въ Шлиссельбургской кржпости, подъ кръпкою стражей, со времени вступленія на престоль блаженной памяти Елисаветы Петровны. Ћъ нему приставлены были заслуженные два птабъ-офи-

${ }^{221}$ ) Сынъ принцессы Мекленбургской, племлнницы имшератрицы Анны Іоанновны и Антона Ульриха, по завъщанію готорой провозглашенъ былъ императоромъ, а по малольттству его правительницей мать его. 
цера, которымъ дано повельніе: ни въ какомъ случаж живаго его не выдавать. Сказанный поручикъ Мировичъ, во время путешествія императрицы въ Ригу, подговорилъ солдатъ своей роты и съ оными вломился въ темницу несчастнаго Іоанна. Упомянутые два штабъ-оФицера, видя, что уже не осталось имъ никакого средства сберечь своего узника, закололи его. Такимъ образомъ Іоаннъ, двадцати четырехъ І'ьтъ, оюончилъ несчастную свою жизнь ${ }^{222}$ ). Мировичъ, вошедъ въ ту камеру, гдъ онъ содержался и увидя его мертвымъ, самъ представиль себя правительству каюъ мятежника. Сенатъ и первенствующіе государственные чины присудили на эшафоть отрубить ему голову, что́ и исполнено. 2) 0 бунть Пугачева сказано было въ І-й главъ. 3) Спертоносная язва во время турецкой войны вкралась въ государство, сильно свиръпствовала, а особливо въ Москвъ ${ }^{223}$ ); съ жестокою зимой и предохранительными средствами она прегратилась. Во время оной, архіепископь московскій Амвросій, увидя, что народъ прикладывался къ образу Боголюббской Богоматери, что́ у Варварскихъ воротъ, и отъ того чернь заражалась, приказаль тотъ образъ снять. Народъ взволновался, вломился въ Кремль, удариль въ набатъ въ новогородскій вечевой колоколь; архіерей оттоль уйхалъ въ Донской монастырь и тамъ спрятался въ алтарж; его вытащили и убили ${ }^{224)}$. Главнокомандующій въ Москвъ фельдмаршалъ, графъ Петръ Семеновичъ Салтыковъ, видя мятежъ, у уххаль изъ города и съ нимъ виъсть бывшій тогда оберъ-полицеймейстеръ Н. И. Бахметьевъ. Но отставной генералъ-поручикъ Петръ

222.) Это происходило $\breve{~ і ю л я ~} 1764$, а Мировичъ казненъ 15 сентября. $M$. JI.

$\left.{ }^{223}\right)$ Моровая язва свиръпствовала въ Москв' съ марта по оЋтяборь 1771 года. $M$. JI.

224) Амвросій убитъ 15 сентября 1771 г. М. JI. 
Дмитріевичъ Еропкинъ ${ }^{225}$ ) усмириль чернь и прекратиль возмущеніе ${ }^{226}$ ). Сказанный к0локоль государыня приказала снять, въ который до того при пробитіи вечерней зари ударяли три раза.

Сиерть императрицы приключилась на $\check{5}$ число ноября; занимаясь дъ.ыами въ своемъ кабинет我, она пошла въ потаенную комнату, и тащъ роковой ударъ поразиль ее; прибъжавшія ея камеръ-фрау и камеръ-медхены нашли ее лежащею на полу безъ тувствъ; на другой день она скончалась ${ }^{227}$ ).

${ }^{225}$ ) Петръ Дмитріевичъ Еропкинъ, генералъ-аншефъ, былъ потомъ съ 1786 по 1790 годъ главногомандующимъ въ Москвй. Онъ род. 1723 , ум. 7 февраля 1805 . M. II.

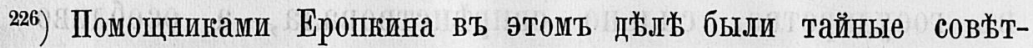
ники Собағинъ и Похвисневъ. $\boldsymbol{M}$. Л.

227) Многіе полагаютъ, и въ̆роятно, что уже въ здоровьи императрицы сдълалась чувствительная перемъна по случаю неудачнаго ея предпріятія. Ей хотьлось внуку свою великую княжну Алегсандру Павловну выдать замужъ за шведскаго короля Густава Адольфа; почеиу поручила министру своему при Стокгольскомъ дворъ вступить по сему предмету въ переговоры. Король и его дворъ, кавалось, съ восхищеніемъ къ топу приступили; въ іюль' король, въ сопровожденіи дяди своего, принца Зюдерманландскаго, прибыль въ Петерборгъ. Великольнные праздники по сему происшествію сль̆довали одинъ за другимъ; король, сдавалось, быль влюбленъ въ прекрасную великую княжну; онъ былъ красивый мущина; съ великимъ удовольствіемъ смотрьли на сію будущую чету. Наконецъ переговоры доведены были до конща; во всемъ было соглашено. Назначенъ уже быль день помолвки и при дворь балъ; всь знатныя особы обоего пола были пов'ъщены; императрица со всъ̌мъ своимъ августьйшимъ домомъ прибыла въ залу, ожидали только жениха, чтобы объявить всенародно о радостной для обоихъ дворов' помолвкъ. Прошло много времени, а король не ьхалъ; между тьмь баль не открывался, послано было узнать 0 причинъ; посланный возвратился и доложилъ государынъ чт0-то тайно. Она послала по дипломатической части находившагося при ней въ довъренности графа Аргадія Ивановича Маргова. Наго- 
Съ печальнымъ симъ извъ̌стіеиъ отправленъ графъ Николай Александровичъ Зубов'ь къ императору Павлу ], законному наслњднигу Россійскаго престола, находившемуся тогда въ Гатчинъ. Государь надъзыъ на него Андреевскій орденъ и поъхаль тотчасъ же въ Петербургъ, приказавъ за собою сльвдовать гатчинскимъ своимъ войскамъ. Весь дворт, сенать и генералитетъ въ Зимнемъ дворцб его ожидали, гдљ тотчасъ ему и присягнули.

Говорять, что императрица сдъзлала духовную, чтобы насльдникъ былъ отчужденъ отъ престола, а по ней бы приняль скипетрь внукъ ея Александръ, и что она хранилась у графа Безбородки. По пріъздъ государя въ С.-Петербургъ, онъ отдалъ ему оную лично; правда ли то, не извъстно, но многіе бывшіе тогда при дворљ меня въ томъ увъряли.

Императоръ пригазаль приготовить печальную церемонію; самъ перенесъ прахъ родителя своего ииператора Петра III изъ Александро-Невскаго монастыря, гдъ̌, подъ предлогомъ,

нецъ, по долгомъ ожиданіи, онъ возвратился съ отвъ̌томъ, что ғо̆роль не можеть согласиться, чтобы королева, супруга его, осталась въ православной греко-гаөолической въ̌ръ, на что уже было изъявлено его согласіе. Императрица такъ была симъ поражена, что приближенные ея замьтили, что едва ли не имъла она легкаго удара, и съ теххъ поръ стала въ духъ и тйломъ ослабъвать. Съ чрезвычайнымъ усиліемъ приняла она на себя видъ твердый. Объявлено было, что король занемогъ и для того на баль не будетъ. Можно судить, каково самолюбію ея было, когда всъ чужестранные министры подъ рукой были предварены, и вдругъ король отказался оть женитьбы. Баль быль открыть на короткое время, и вскорь императрица отбыла во внутренніе покои. Л. $Э$.

Густавъ IV Адольфь род. 1 ноября 1778, вступиль на престоль въ 1792 году и отказался отъ него въ 1810. 0нъ женился въ конщ' 90-хъ годовъ на принцессь Баденской, сестрь нашей императрицы Елизаветы Алексъевны. Онъ жиль посль 1810 года в́ь Германіи, Шівеціи, Голландіи и проч. подъ именепь полковника Густавсона и умеръ 7 февраля 1837 года. $M . \mathcal{M}$. 
чт0 онъ быль не коронованъ, быль погребен'ь. Онъ былъ поставленъ на одномъ катафа̇лкъ съ покойною императрицей, и вмьсть погребены въ соборной церкви Петра и Павла, гдъ прахъ покоится всъхъ императоровъ и императрицъ.

На другой же день онъ указалъ, чтобъ отдаваемые имъ при пароль⿱宀 приказы признаваемы были за именныя повельннія, и того же дня пожаловалъ въ фельдмаршалы князя Н. В. Репнина, графомь и фельдмаршаломь М. $\theta$. Каменскаго, графа В. ПІ. Мусина-Пупгкина, графа И. ПІ. Салтыкова ${ }^{228}$ ).

Зять мой, Сергъй Кузьмичь Вязмитиновъ, пожалованъ военнымъ губернаторощъ въ Каменецъ-Пододьскій. На другой день прибылъ новой курьеръ съ иввьстіемъ, что вмъсто того онъ назначенъ въ Черниговъ, куда онъ и отправился въ самой скорости; и только что таџъ пробыль дня два, пожалованъ быль коммендантомъ в'ь Петропавловскую крьпость.

Гатчинскія войска и всъхъ ихъ оФицеровъ государь сравнялъ въ чинахъ съ старою гвардіей, многимъ изъ нихъ даль государственныя мъста, какъ-т0: Обольянинова ${ }^{229}$ ) пожаловаль провіянтмейстеромъ, а потомъ генераль-прогуроромъ; Аракчеева ${ }^{230}$ ) коммендантомъ петербургскимъ; по

228) Авторъ ошибается на счетъ графа Мусина-Пушкина и Каменскаго: они пожалованы фельдмаршалами въ Москвъ ъ̆ апрьля 1797, въ день коронаціи Павла I, вмысть' съ Эльмтомъ. При восшествіи на престоль Павла, этого званія были удостоены: графь И. ПІ. Солтыковъ, графъ Н. И. Солтыковъ, князь Н. В. Репнинъ и графъ И. Г. Чернышевъ. Такимъ образомъ въ пять мъ̌сяцевъ, въ мирное время, пожаловано было семь новыхъ фельдмаршаловъ. $M$. $J$.

${ }^{229}$ ) Петръ Хрисанфовичъ Обольяниновъ былъ долгое время впосль̆дствіи московскимъ губернскимъ предводителемъ дворянства и умеръ въ сороковыхъ годахъ. $M . J$.

230) Графъ Алексьй Андреевичъ Арапчеевъ, генералъ отъ артиллерік, род. 1769, ум. 1834. M. J. 


\section{$-197-$}

времени Кутайсова ${ }^{231}$ ), своего брадобрия, ивъ полоненныхъ Турокъ, графошъ и оберъ-гобъ-птталиейстеромъ двора (то былъ его первый любимецъ), дав' имъ великія имьнія. Дико было видызть гатчинскихъ офицеровъ вмьсть съ старыми гвардейскими: эти были ивъ лучшаго Русскаго дворянства, болье придворные, нежели фрунтовые офицеры;

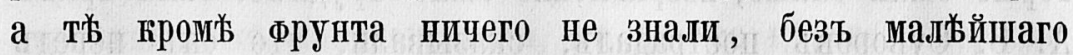
воспитанія, и были почти оборышъ изъ арміи; ибо какъ они не могли быть употреблены въ войнљ, и кромъ переходовъ изъ Гатчины въ Павловскъ и изъ Павловска въ Гатчину ниғуда не перемъьщались, потому мало и было охотниковъ служить въ гатчинскихъ войскахъ. Однакожъ нъсколько было изъ нихъ и благонравныхт людей, хотя безъ особливаго воспитанія, но имъ̌ющихъ здравый разсудокъ и къ добру склонное расположеніе, а потому, пріобыкши къ важнб̆йшимъ должностямъ, они служили съ пользой г0сударству.

Всъ генералы, начиная отъ фельдмаршала, сдйланы были шефами полковъ, а въ недостающіе полки произведены полковники въ генералъ-майоры. Такое вдругъ множество явилось генераловъ, и такое скорое производство потеряло уваженіе къ онымъ, равно какъ и къ орденамъ: ибо императоръ не раздавалъ, а разиетывалъ ихъ.

0нъ перемънилъ мундиры, одыълъ всю армію на манеръ прусскій прошлаго въка; тоже и самый прусскій старый военный уставъ издалъ къ исполненію, введя совсъмъ новый родъ службы, такъ что старые генералы не болье знали новую службу какь и० вновь-произведенные прапорщики; старымъ людямъ, сдызлавпимъ навыкъ къ прежнему обряду, трудно не только было отправлять ее, но даже и понять. За то ежедневно одни отставлялись, другіе исключались,

231) Графъ Иванъ Павловичъ Кутайсовъ, цййствительный тайный совътнићъ, ум. 9 января 1834 г. M. Л. 
многіе генералы съ дарованіями принуждены были оставить службу; но тймъ не менъе производство шшло съ непостижимою скоростію, такъ что, едва получа одинъ чинъ, какъ уже и въ другой производились. Служащимъ въ отдаленныхъ корпусахъ еще нъсколько было полегче, а тымъ, которые были ближе, несравненно было труднже. Саль гратъ А. В. Суворовъ пострадалъ; сказывали, что онъ передъ разводошъ показываль свою блажность, говоря: “Пукли не пуика, коса не тесакъ, а л не Прусакв: $л$ фельдмариаль въ поль, а не при пароль). Удивительно, что сей тонкій человъьъ говориль такія рычи, которыя не сходствовали съ его умомъ. Государю о томъ донесли, и онъ послаль за нимъ фельдъегеря, съ которымъ онъ пріљхаль и явился на другой день на вахтъ-парадъ.

Вскорж онъ сосланъ былъ въ свои деревни, въ Новогородской губерніи находящіяся, гдъ и проживаль подъ присмотромъ земской полиціи, до назначенія его командовать россійско-австрійскою арміей въ Италіи противъ Французовъ.

Строгость касательно военныхъ была черезмирна. За бездъ̌̆лиц псключались изъ службы, заточались въ крњпость и ссылались въ Сибирь; аресты считались за ничто; бывало по нъскольку генераловъ вдругъ арестованныхъ на гауптвахть. Гражданскимъ чиновникамъ и частнымъ лицамъ было не легче; Вмъссть্ же съ симъ изливались великія милости. Если гнь̆въ государя сколько-нибудь замедлитъ наказаніемъ, то тӝ же самые люди не только приходили въ милость, но и осыпались благодъъяніями. Можно сказать, что онь совсъит быль не злопамятенъ; бывали времена, и не рйдко, онъ показываль благородную душу и къ добру расположенное сердце. Думать надобно, что ежелибы онъ не претерпьль столько. неудовольствій въ продолжительное царствованіе Екатерины II, характеръ его не былъ бы такъ раздраженъ, и царствованіе его было бы счастливо для Россіи, ибо онъ помышляль о благъ оной. Но или онъ не 
имъ̌ль способности къ тому, или не могь переломить крутой свой нравъ и принять благоразумньйшія мъры. Словощъ, царствованіе его для всъхъ было чрезвычайно тяжело, особливо для привыкшихъ благоденствовать подъ кроткииъ правленіемъ обожаемой монархини. Ћонечно, и при ней были несправедливости, но онъ были чрезвычайно ръдни и претерпььвали ихъ частныя лица, но не все цйлое. Совершенства во всемъ мірь нетть.

По вступленіи на престоль, государь тотчасъ прегратиль персидскую войну, приказавъ полкащь выступить изь персидскихь предъловь каждому по себ'ь и съ шахомъ утвердиль мирь.

Чтобы привявать къ себњ духовенство, сталь жаловать оное орденами.

1797. Въ конць парта 1797 года государь прибыль въ Москву, а въ апрьль' гороновался. Щедроты свои, по обыкновенію, расточалъ, жаловаль чинами, орденами и раздаваль казенное имущество и деревни. Посл' чего черезъ Смоленскъ отправился вь Петербургь.

Бывшіе шесть 0ренбургскихъ полевыхъ батальоновъ, соединя по два, государь назвалъ полками; третій батальонъ, которымъ я командовалъ, поступиль со вторымъ въ УФимскій польь, шефомъ коего сдъ̌ланъ генералъ-щайоръ графъ А. $\boldsymbol{\theta}$. Ланжеронъ ${ }^{232}$ ). Инспекторомь войскъ, находившихся

232) Графъ Александръ Өедоровичъ Ланжеронъ, генераль отъ инфантеріи, род. 13 января 1763 г., ум. 4 іюля 1831 г. Онъ быль родомъ французь, сражался съ Лафайетощъ за американскую независимость и эмигрировалъ въ Россію в' 1790 году. Онъ прославился пакъ боевой генералъ, У гакъ новороссійсгій генералъ-губернаторъ (1816-1823) сдъљалъ много пользы. М. $Л$.

Ланжеронъ былъ любезньйшій и отлично образованный человъ̌къ. Есть его статьи въ роялистскомъ изданіи XVIII въна: Les actes des. apôtres. Въ Русскомъ Архивъ будетъ напечатана зашьтка о Ланжероньь импер. Екатерины. II. $\boldsymbol{~}$. 
въ Уфимской, Казанской и Пермской губерніяхъ, тожъ 0ренбургскимъ военнымъ генералъ-губернаторомъ и шефомъ Рыльскаго пъххотнаго полка генераль оть инфантеріи ${ }^{233}$ ) Игельстромъ, ғотораго изъ деревень его государь вызвалъ, но скоро уже къ нему оказалъ неблаговоленіе. Причиной сего было сльдующее: черезъ нйсколько врешени по назначеніи его ка сіе мъсто спросиль его императоръ, много ли ему

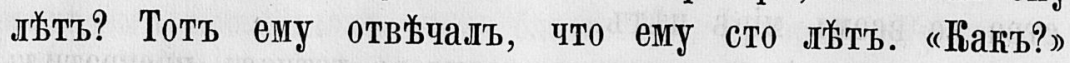
спросиль государь. Игельстрощъ отвйчаль: «Шестьдесять

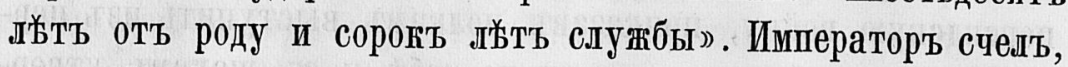
что сей нъ̌мецкій каламбуръ означалъ, что онъ не хочетъ служить, и, обернувшись, сказалъ тутъ бывшимъ: «Я его вытащилъ изъ навозной кучи, а онъ уже отговаривается дряхлостію» .

Игельстромъ чуть было меня не сдб̆лалъ несчастливымъ, и вотъ въ какомъ случаъ. Былъ полковникъ князь П. В. Мещерскій ${ }^{234}$ ), сверхъ комплекта, въ Оренбургскомъ драгунскомъ полку; онъ выпросилъ отъ корпуснаго своего командира С. К. Вязмитинова ордеръ, чтобы пребывать въ Москвъ, какъ не имъющему никағого дыъла въ полку. Зять мой, по его просьбъ, даль ему повельніе, чтобы собираль изъ всъхъ

${ }^{233}$ ) Генералъ-аншефы названы генералами отъ инфантеріи и генералами отъ кавалеріи; генералъ-поручики генералъ-лейтенантами.

234) 0нъ быль потомь генераль-майоромъ и шефомъ С.-Петербургскаго драгунскаго полка. Вошелъ въ доносъ, что будто дњ̈лается противъ императора заговоръ въ его полку дворянствомъ Смоленской губерніи, гдъ̌ тотъ полкъ квартировалъ; поводомъ сего было: нъскольк0 молодыхъ шалуновъ шутили на счетъ странныхъ мундировъ и многаго, бывшаго смйшнаго, что̀, конечно, предосудительно, но о заговорь никакого помышленія не было; однакожъ многіе пострадали. Симъ доносомъ Мещерскій вошелъ въ милость императора, быль гофмаршаломъ двора, по самый конецъ живни государя, и директоромъ театра. $\pi . \vartheta$.

Князь Прокофій Васильевичъ Мещерскій славился своимъ остроуміемъ и свйтскими талантами. $M$. $\boldsymbol{I}$. 
нижнихъ чиновъ, бывшихъ при гоммиссаріать оренбургскаго горпуса, кағъ скоро въ нихъ не будетъ надобности, для отправленія ихъ къ своимъ полкам'ъ и батальонамъ. Тағимъ образомъ онъ отправилъ шесть человъьъ въ мой батальонъ при своеиъ сообщеніи; но ко инь явилось только пятеро, а одного Мещерскій оставиль при себъ. На трехл安нее избираніе новыхъ предводителей и судей въ Симбирск'ь, зять мой поъхаль туда и меня взяль съ собою, пуда и Мещерскій изъ Москвы прибылъ, и просиль меня, чтобъ имъ оставленнаго моего солдата оставилъ при немъ. Но какъ я самъ собою сего сдъдать не осмъллися, то и спросилъ на то повельинія моего зятя, на что́ онъ словесно и приказалъ. Мещерскій изъ Симбирска отправился опять въ Москву, и съ тиххъ поръ я не имъัљъ никакого извъстія, гдъ онъ. Игельстромъ, разсмотрьввъ отлучную вйдомость бывшаго моего батальона, замьтилъ, что сказанный солдатъ числится при полковник出 князъ Мещерскомъ, и требовалъ отъ меня, по какому повельнію онъ у него находится. Я донесъ, что по словесному повельнію бывшаго коргуснаго командира Вязмитинова; на это онъ приказалъ мнґ сказать, что словеснаго приказанія онъ не принимаетъ, и даеть мнъ сроку двъ недъыли отыскать того соддата, а по истеченіи того срока, если тотъ солдатъ не будеть отысканъ, представитъ государю императору. Гдъ былъ тогда князь Мещерскій, и какъ отыскать его въ такое короткое время? Ожидалъ я понести строгое наказаніе и можетъ-быть даже быть разжалованнымъ. Но къ счастію моему, получено отношеніе отъ смоленскаго военнаго губернатора Фило-

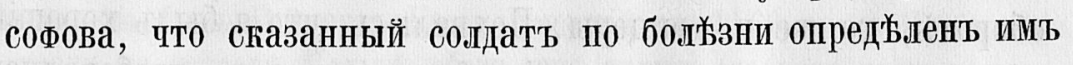
въ смоленскій гарнивонный полкъ, чҺ̌ъ это и кончилось. Однакожъ Игельстромь долго быль ко мнё худо располо-

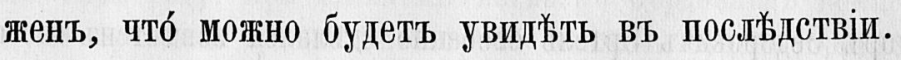

ІІефъ нашъ графъ Јанжеронъ прибылъ въ полкъ, и мы съ нимъ сдылались друзьями, каковыми остались навсегда. 
Графъ хотйль видъться съ своимъ инспекторомъ и просиль его позволенія прізхать къ нему въ Оренбургъ; но какъ отъ своего мъста никому, безъ особливаго позволенія государя, отлучаться не позволялось, то Игельстромъ увъдомиль его, что онъ сапъ хочеть его видьтьь, но позволить пріъхать въ 0ренбургъ не сиъетъ, а чтобы Ланжеронъ выҺхалъ къ нему инкогнито въ Бугульму, когда онъ поъдетъ по инспекціи. Графъ, будучи имъ извъценъ, туда ьздиль, и по возвращеніи своемъ спросилъ меня: не сдъ̈лаль ли я какого неудовольствія Игельстропу? Я почти ему быль не извъсстенъ и никогда не было къ тому случая. Графъ мнъ признался, что Игельстромъ предостерегаль его, чтобы быль со мною осторожнымъ, какъ съ человб̌комъ безпокойнымъ и большимъ интриганомъ, но графъ меня довольно горотко

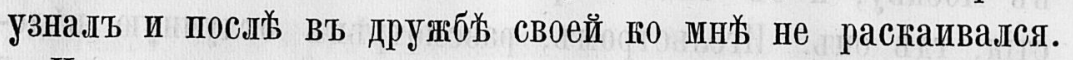

Императоръ послаль во всъ инспекціи гатчинскихъ генераловъ и штабъ-оФицеровъ, учить обряду, порядку и фрунтовой службъ. Въ нашу инспекцію и сибирскую, посланъ быль майоръ Эртель $\left.{ }^{235}\right)$. Онъ пріъхалъ въ Оренбургъ въ то время, когда Игельстромъ объъзталь инспекщію; штабъ-опицеры Рыльскаго полка были состарьвшіеся въ прежней службж, а потому, что̀ онъ имъ показывалъ и толковалъ, они ничего не поняли. Оттуда Эртель поьхаль по линіи и въ Сибирь. Уже на возвратномъ пути пріъхалъ онъ въ УФу, гдњ квартировалъ нашъ полкъ. Мы не удовольствовались его словесными толкованіями, а спормировавъ батальонъ, потребовали, чтобъ онъ показалъ все сказанное въ уставґ̌, что́ долженъ замъччать батальонный командиръ во всякомъ оборотй, то же и оФицеры. Похвалюсь, что я былъ хорошій Фрунтовой оФицеръ; эволюціи были просты, требовались

235) Өедоръ Өедоровичъ Эртель особенно едъ̆лался извъ̆стенъ своею распорядительностію какъ с.-петербургскій оберъ-полиціймейстеръ, должность котораго занимашъ съ 1802 по 1808 годъ. M. Л. 
только одна точность и мелочи удобопонятныя, почему Уфимскій полкъ быль выученъ какъ нельзя лучше по новому уставу, но Рыльскій полкъ учился по старопу обряду.

За отдаленіемъ, кромъ общихъ анекдотовъ, ғасающихсп двора и всего происходившаго, мало доходило до моего свћ̈дънія.

Въ конць сего года скончался знаменитый нашт полководецъ, графъ Петръ Александровичъ Румянцевъ-Задунайскій; государь на всю армію наложилъ трехдневный траурь ${ }^{236}$ ).

1798. Императоръ приняль титуль магистра державнаго ордена Св. Іоанна Іерусалимскаго ${ }^{237}$ ), почему хотбыль имб̆ть островъ Мальту въ своемъ владъніи; уже назначены были туда военный губернаторъ и гоммендантъ. Съ Турғами и Англичанами заглючиль союзъ противъ Франщузовъ; послана была әскадра въ Средивемное море и вмйсть' съ турецкою дъйствовали; гапитанъ флота 2-го ранга Белли съ небольшимъ тисломъ войска заняль Неаполь; государь, получа 0 томъ донесеніе, сказалъ: “Онъ меня удивилъ, да и я его удивлю». Послалъ ему орденъ Св. Анны 1-й степени. Кромъ Белли, въ полковничьещъ чинъ, никогда никто таковаго не имъљль.

Въ 1798 году я пожалованъ въ полковники, а въ Февраль̈ полкъ получиль повельніе идти на ревю в' Казань,

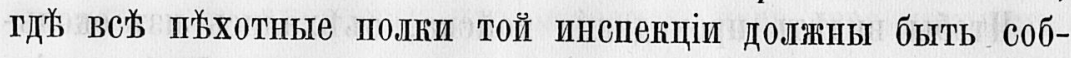
раны, куда и государь намъревался прибыть.

236) Тутъ авторъ ошибается: Румянщовъ умеръ 8 дек. 1796 г. М. Л.

${ }^{237}$ 0рденъ Святаго Іоанна Іерусалимскаго учрежденъ был'ь во время ғрестовыхъ походовъ, въ ХІІ въ̌къ. Первымъ велигимъ магистромъ его былъ Раймондъ Подіо, умершій въ 1160 году. Пребываніе ордена на островъ Мальть обезпечено ордену (до того времени находившемуся на Родосъ) жалованною грамотой императора Карла $r$, въ 1530 году. При велиғомъ магистрҺ̆ Фердинандъ Гомпешъ, Французы прогнали орденъ с'ь острова Мальты. 0рденъ прибъгнулъ подъ защиту императора Павла, готорый сдйлался 71-мъ великимъ өго магистромъ, принявъ это званіе 29 ноября 1798 года. $M . . I . \cdot$ 
Игельстромъ предписалъ, чтобы полги, идя на ревю, соображались съ уставомъ. Какъ еще въ томъ краю, въ сіе время, бываеть сильная зима, по дорогъ же селенія разнаго рода Татаръ, малыя и рбдкія, то онъ и приказалъ Уфимскому полку, чтобы за шефскимъ батальономъ чрезъ день слъдоваль полковничій батальонъ, а за онымъ чрезъ день гренадерскіе роты съ артиллеріей, при полку находившеюся, и гоппиталь.

Взошедъ я съ батальономъ на большую оренбургскую дорогу, остановился на ночлегъ, Казанской губерніи, въ деревнгі Ерыклы, принадлежавшей помъщику Рыбушкину, гдъ онъ и самъ проживалъ. Адъютантъ Игельстрома, проъхавъ, сказалъ мнй, тто генералъ проситъ меня приказать приготовить ему квартиру въ сей деревнь для ночлега. Я выпросилъ у помъщика для генерала въ его домъ двъ̌ комнаты, а мнъ̌ занята была квартира не подалеку: изба, которая одна и была только съ трубой, а прочія всъ избы были черныя. Я поставиль въ квартиръ его высокопревосходительства двухъ часовыхъ, какъ сказано въ уставъ, кром'̆

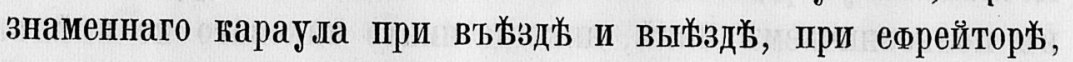
по три человъ̆ка. Изготовя рапортъ, со всъми офицерами, въ шарфахъ, ожидаль я инспектора.

Чтобы видъ̌ть проходящія войска, съъхались изъ окольныхъ деревень родные и знакомые помьъщика Рыбушкина, и въ числг ихъ много было дамъ, которыя съ хозяйкой вышли встрботить украштеннаго съ̌динами генерала.

Какъ скоро вышелъ онъ изъ кареты, я подалъ ему рапортъ; вдругъ спросилъ онъ меня, указывая на дамъ:Это кто? «Әто ховяйки дома, сказаль я, въ которомъ приготовлена квартира для вашего высокопревосходительства». - Какъ, вы хотите надо мною, надъ старикомъ, пгутить, г-нъ полковникъ? Время мое волочиться уже прошло; я вам'ь это уступаю; вы можете занять мою квартиру, а я пойду въ вапу. “Моя квартира очень дурна и даже очень не оп- 


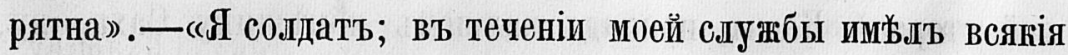
квартиры, ведите меня туда». Только что вошли мы в'ь оную, какъ онъ меня спросиль: - Гдъ ваша гауптвахта и ваши пикеты? «Въ главахъ устава, когда идутъ полки на ревю, сказано имбтть только одинъ знаменный караулъ».-Какъ, г-нъ полковникъ, вы хотите меня учить? «Я докладываю вашему высокопревосходительству свое оправданіе .-Нњъть, г-нъ полковникъ, въ уставъ сказано: надобно имбть гаупт-

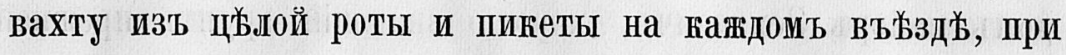
двухъ офищерахъ и по шестидесяти рядовыхъ. «Ваше высогопревосходительств0, то сказано о кантониръ-квартирахъ».- А это разьъ не кантониръ-квартиры? «Я думалъ, что кантониръ-квартиры бываютъ въ военное время и погда непріятель угрожаеть нападеніемъ, или для иныхъ политическихь видовъ, гдъ надобно брать предосторожности).Вы меня опять начали учить? (Какъ мнъ осиълиться?»Для чего же вы не исполняете, по уставу и моему предписанію? « $\mathscr{A}$ докладываль, что исполняль какь сказано въ главъ̆, когда полюи идуть на ревю».-Вы меня учить хотите, такъ какъ и вашего шефа, и върно, по наученію вашеиу, онъ идеть тьыъ же порядкомъ. «乌 соображался и исполняль его приказанія». Этотъ разговоръ или, лучше сказать, его выговоры продолжались часа два; наконецъ онъ насилу меня отпустиль и на другой день поутру рано уъхалъ.

Я попьстиль сію ничтожную сцену, единственно чтобы показать, къ чему я долженъ былъ готовиться, гогда мы предстанемъ предъ императоромъ Павломъ, передъ которымъ все трепетало. Дурное расположеніе қо мнъ инспектора, который, почти не зная меня, готовъ быль при малъйшемъ случаб меня погубить, я не могу понять. Какой злой духъ могъ такъ вооружить его противъ меня?

Наконецъ весь нашъ полкъ соединился въ сел' Алексъевскомь, отстоящемъ оть Казани во ста верстахъ, по Іъ- 
вой сторонъ Камы, принадлежавшемъ помъщику Сахарову, и въ готоролъ считается оқоло трехъ тысячъ душъ. Туда черезъ нъскколько врешени и Рыльскій полкъ прибыль; туть мы простояли всю весну, отдыхали и учились, чтобы предстать во всей исправности передъ императора.

На другой день прибытія моего въ Алексъевское, мой батальөнъ наряженъ быль въ карауль, и при вахтъ-парадъ смъ̌шное случилось происшествіе. Командоваль вахтъ-парадомъ майоръ Зенкевичъ, хорошо знающій фрунть прежней и новой службы. Игельстропь приказаль формировать изъ средины полъ-дивизіонную юолонну, чего въ Павловскощъ уставъ̌ не было, почему офицеры и забыли. Майоръ спросиль: Какъ прикажете? По старому?-Какь по старому? Велите формировать колонну. Майорь опять спросиль: Какъ прикажете? Туть Игельстромъ вышель изъ себя, сталь самъ командовать старымъ и охриплыи голосомъ; никто его не понималъ; онъ выводилъ взводы и нагонецъ, приведя все въ безпорядокъ, кричалъ: «Я несчастный! Государь исключитъ меня изъ службы, и этимъ буду я обяванъ этоіг полку». Подходилъ юъ Ланжерону и сказывалт, какъ было въ саксонской службњ, гдъ онъ быль капитаномь до вступленія его въ россійскую службу, а тоть отвъ̌чаль, какъ бывало во французской службъ. Кончилось на мнъ, что всему я виноватъ.

Посльъ несчастнаго сего вахтъ-парада, пошли мы къ нему на квартиру; туть меня онъ атаковаль: чему вы учились? Я отвҺ̆чалъ: “Всему тому, что́ сказано въ уставъ и какъ намъ показаль Эртель». - Эртель ничему не училъ, сказалъ онъ, гропь порядка вахтъ-парада. Я ему объяснилъ, что когда Әртель прівхаль къ намъ въ УФу, т0, по требованію нашему, онъ намъ показаль всъ эволюціи батальоннаго ученія. Тогда Ительстромъ увидъљль, что его польъ не имъеть понятія по новому уставу, а мы напротивъ хорошо приготовлены. Онъ просиль меня, что, когда 
польъ его придеть, я бы показаль его штабъ-оФицерамъ, и уже я, можно сказать, сдь্лался его любимцемъ, и онъ говориль графу Ланжерону, что сожальетъ, что имъль обо мнеь невыгодное мнжніе; но теперь, узнавъ свою ошибку, почитаеть себя предо мною виновнымъ.

За то онъ ивмучиль безпрестаннымъ ученьемъ свой польъ, равно какь и парикмахеровь: ибо, чтобы болье угодить

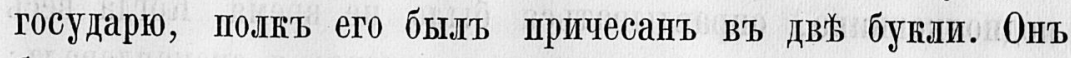
безпрестанно твердиль Ланжерону: «Боюсь за васъ; накладныя букли изъ шлят государь не любитъ, и вы увидите, что за то вачь будеть бъда». Но еслибъ было и такъ, выучить въ три недтыли парикмахеровъ было невовможно, да и безъ того полки были въ страхь, знавъ, что когда государь бываль въ дурномь расположеніи (что случалось не ръдко), какъ бы который полкъ ни быль исправенъ, все было не въ угоду.

Въ исходе' мая мы выступили ивъ Алексъевскаго, и расположилась вся инспекція въ десяти верстахъ около Казани, по разнымъ дорогамъ.

Государь прибылъ въ Казань съ великими князьями Александромъ и Константиномь Павловичами, 3-го іюня, и прогнеьвался на Игельстрома, что войска до прибытія его еще не вступили, приказавъ ему распорядить, чтобы каждый полкъ вступилъ на другой день поутру въ разные часы, такъ чтобъ онъ каждый могъ видыть особо.

Въ семь часовъ утра вошель Екатеринбургскій полкъ въ Сибирскую заставу; шефь онаго быль изъ гатчинскихъ, генералъ-майоръ Пъвцовъ. Въ восешь часовъ долженъ былъ войдти У Фимскій полюь. Всъ шли съ трепетомъ; я болье ужасался, чймъ идя на штуриъ Праги.

Государь быль у самой заставы. Передо мною шель батальонъ шефскій, который перешъниль ногу; я тотчась перемьниль также свою, чтобы маршировать согласно съ предъидущимь батальономъ. За мною шель сверхъ-гомплектный 
подполковникъ кн. Ураковъ, который пооробълъ, и не замътивъ, что я перемъниль ногу, шелъ по прежнему, какою ногой шелъ весь мой батальонъ. Государь сказалъ: «Господа штабъ-оФицеры, не въ ногу идете». Я, видя, что иду въ ногу шефскаго батальона въ̌рно, ть̌ыъ же шагомъ продошжалъ. Тогда государь гнъъвно закричалъ: «Полговникъ Энгельгардтъ не въ ногу идетъ». Увидъъвши ошибку моего подполковника, оправдываться было не время. Когда весь полкъ прошелъ, ударили подъ знамена; я скомандовалъ: cz поля. Надобно объяснить, что дъълалось это на марш' по тремъ флигельманамъ въ четырнадцать пріемовъ, и оғанчивалось ть̌мъ, что ружья обертывались внизъ дуломъ, а прикладами вверхъ, что́ было чрезвычайно трудно. Импе-

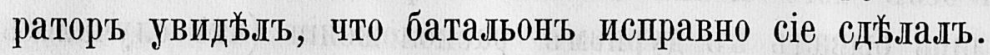

Посль сего императоръ поґхаль смотръть Рыльскій польъ, но онъ уже вошелъ, и полковника того полка Барыкова за болъзнію не было; все сіе причтено въ вину Игельстрому. Надобно было войдти сперва полку Рыльскому, потомъ Игельстрому быть при государъ при входъ всъхъ полковъ его инспекціи. Въ приказъ государь объявилъ спасибо, за входъ, Екатеринбургскому и Уфимскому полкамъ.

Ввечеру того дня дворянство давало балъ, который удостоиль своимъ присутствіеиъ императоръ съ великими князьями; также дворянство пригласило на сей балъ пришедшихъ полковъ штабъ-офицеровъ. Государь танцоваль польской со многими дамами. Увидя военнаго губернатора Јассія въ башмакахъ съ тростью, онъ подошель къ нему и сказалъ: «Какь? Лассій въ башмакахъ. и сь тростью»? Тоть ему отвъчалъ: - А какъ же? “Ты бы спросиль у петербургскихъ». - $Я$ ихъ не знаю. “Видно ты не любишь петербургскихъ; такъ я тебъ скажу: когда ты въ сапогахъ, знакъ, что готовъ къ должности, и тогда надобно имёть трость; а погда въ башмакахъ-знакъ, что хочешь куртизировать дамъ, тогда трость не нужна». Comment, votre 
majesté, voulez vous qu’à mon âge je sache toutes ces misères? (Какъ вы хотите, ваше величество, чтобы въ мои ль̌та я могъ знать всъ эти мелочи)? Государь разсмљялся сему ирландскому отвъту, ибо Јассій быль Ирландецъ. Государь, пробывъ часа съ два, отправился въ домъ отставнаго генералъ-майора Лецкаго, гдъ онъ имъљъ свое пребываніе.

丂-го числа быль спещіяльнй смотрт на Арскомъ поль (на томъ самомъ, гдъ̌ Михельсонъ разбиль Пугачова). Когда полки выстроились по уставу, то подскакалъ к0 мнь̆ бывшій при государґ бригадъ-майорь Н. И. Јавровъ, съ кот0рымъ мы были коротко знагомы во время турецкой войны въ Молдавіи, и сказалъ мнъ: “Не такъ у тебя стоятъ подпрапорщики) (ибо, за нб̌юоторое время до вступленія полпов' въ Казань, перешънены штаты, и подпрапорщики названы уже были вторыми послғ фельдфебелей). Видя, что это уже исправлено въ шефскомъ батальонь̆, который за суетой меня не увьдомилт, я перемъниль въ первыхъ двухъ ротах', а въ трехъ ротахъ еще не успљљь, какъ уже государь подъъзжаль къ моему батальону на флангъ. Я побъжаль стать на свое пъстто; онъ про'ьхаль мимо меня съ суровымъ видомъ. Теперь-то я пропаль, думалъ я; однакожъ, видно, императоръ сего не замб̌тильъ. Посль мы проходили миюо его церемоніяльнымъ маршемъ. Въ пригазъ объявлена была всъмъ полкамъ благодарность.

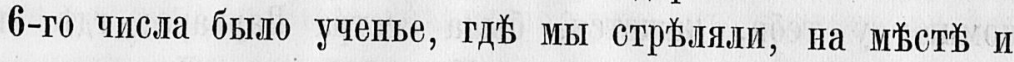
маршируя плутонгами, полудивизіонами и дивизіонами. Когда стали стрџлять батальонами, какъ въ первой линіи было пять батальоновъ и мой батальонъ быль на льввоџь

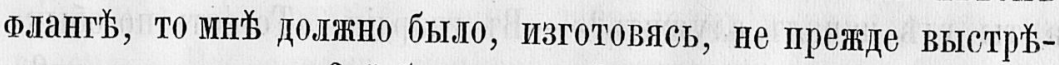
лить, какт когда 2-й батальонъ Рыльскаго полка, выстрћливт, вовьметь ружья на плечо, а какъ сей батальонъ очень мъшкалт, то великій гнязь Александръ Павловичь,

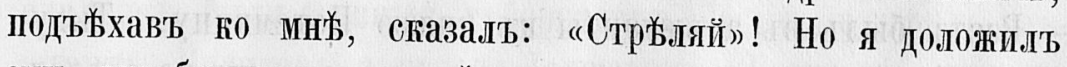
егу, что батальонъ, послё котораго мнб должно стрьљлять, 
еще не зарядилъ ружья; хотя онъ мнеь повториль сіе приказаніе раза четыре, но я не спьшиль, выждалъ и выстрьлиль въ свое время, когда было должно; залпь быль удачный. Государь замхтилъ, что я не торопился исполнить приказаніе его высочества насльдника, ибо онъ былъ почти у моего батальона на Флангь⿱⺊口 и остался доволенъ моею исправностью.

По окончаніи ученья, въ комнат年 государя и при немъ военный губернаторъ Лассій отдавалъ пароль и приказъ; я тоть день быль дежурнымъ и быль въ кругу съ прочими, принимавшими приказаніе. Государь подошель ко мнь сзади, положиль руку на мое плечо, и пожимая, спросиль: “Сћажи, гды ты выпекся? Только ты мастерь своего джыла. Я руку его, лежавшую у меня на плечь, ц'ыловал какъ у любовницы, ибо въ первые два дня я потеряль бодрость и ожидаль уже не того, чтобы обратить на себя его вниманіе, а быть исключеннымъ изъ службы.

Тотъ день приказано было мнъ быть къ столу. Какъ скоро государь вышель изъ внутреннихь комнатъ, то прямо подошель ғ0 мнгъ и спросиль: “Из' какихь ты Энгельгардтовъ, лифляндскихъ или смоленскихъ?»-Смоленскихъ, ваше величество. «Знаю ли я Ћого ивъ твоихъ родныхъ?»- Ћогда ваше величество въ 1781 году изволили проъзжать черезь Могилевъ, отецъ мой тогда быль тамъ губернаторомъ. «А, помню; у тебя, кажется, была сестра Варвара; гдь она теперь?» - Она замужемъ за Наврозовымъ. “Давно ли она вышла замужъ?»-Въ нынбшнемъ году (тогда ей было тридцать три года). “ Не молодою же она вышла отроновицей; а ты гдъ началъ служить?)—-Въ гвардіи. (Т0-есть по обыкновенію всъхъ васъ, тунеядцевъ-дворянъ; а ташъ какъ?» Я было хотьљљь пропустить, что быль адьютантомъ у свь̆тльйшаго князя, и сказалъ:-А потомъ въ арміи. “Да какъ?» - Взять быль въ адъютанты къ князю Потемкину. «Тьбу, въ какіе ты попаль знатные люди; да какъ ты не сдъљлал- 
ся негодяемъ, гаґъ всъ при немъ бывшіе? Видно много въ

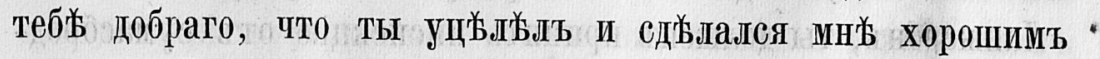
слугой.) Векорж послгь того пошли за столь.

7-е. Были маневры; государь разгнњвался на Рыльскій полкъ за худую стръльбу, а УФимскимъ быль доволенъ, особливо ноимъ батальономъ. Когда я прошель мимо его церемоніяльнымъ маршенъ и, отсалютовавъ, взлль эспантонъ въ правую ругу и подошель къ нему, императорь сказалъ мнъ: “Становись на кольни-видишь, какъ ты выросъ великъ: иначе не могу тебя обнять». Когда я сталь на кольни, онъ поцъзовалъ неня въ объ щеки.

8-е. Тоже быль маневрт, по окончаніи потораго и посль отданія приказа, государь пожаловаль орденъ Св. Анны 2-й степени гр. Ланжерону, который епу сказаль: «Государь, доставляють мнъ вашу милость труды моего полқовника; смъюю увърить ваше имшераторское величество, что ежели полкъ мой имълъ счастіе вамъ быть угоденъ, онъ имъ до того доведенъ. - «Знаю, сказаль государь, у меня и для него есть подарокъ, а посль дамъ ему и болье». Посль того, подоввавъ меня къ себъ, пригазаль стать на кольно, вынулъ ивъ ноженъ шшагу, даль мнъ три удара по плечамъ и пожаловалъ шппагу съ аннинскимъ крестощъ.

В0 все время пребыванія государя въ Казани, всякій день, въ шесть часовъ пополудни, государь выходиль въ садъ дома Јецкаго, и было объявлено, что онь желаеть видътьь въ ономъ саду ежедневно газанскихъ жителей. Со многими дамами и тамошними дворянами онъ говорилъ. Ћогда встръьчалсп онъ съ офицерами УФимскаго полка, то говориль имъ: «Спасибо, господа; вы меня забавляли; я вами очень доволенъ. ” Во всякомъ приказъ Уфимскому полку была похвала.

Послг объда, передъ выходомъ государя въ садъ, передъ спальней, были военный губернаторъ Јассій, генералъ-адъютантъ Нелидовъ и графъ Јанжеронъ. Государь, вышедъ 


\section{$-212-$}

изъ спальни, подошель къ графу Ланжерону и сказаль: «Јанжеронъ, ты должень принять инспекцію оть сумасороднаго старика Игельстрома.» - Государь, сказаль графъ, я не могу. “Какъ! ты отказываешься отъ моей милости?)«Тысяча резоновъ заставляютъ меня отказаться оть оной; первое, я еще не силенъ въ русскомь языкъь). Государь съ болышимъ гнйвомъ отошелъ отъ него на другой конецъ комнаты, и, подоввавъ Нелидова, сказаль ему: “Поди спроси Јанжерона, какіе остальные резоны заставляютъ его отказаться отъ инспекціи?» Графъ Ланжеронъ отвъчаль:- Первый и посльдній: Игельстромъ мнь благодьтельствовалъ, и я не хочу, чтобы мойъ лицомъ - человььу, состарьвшепуся въ службъ его императорскому величеству, было сдйлано таковое чувствительное огорченіе». Не успьљљ онъ вымолвить, какъ государь подбъжаль къ нему еъ фуріей, топнуль ногой, пыхнуль и скорыми болышими шагами ушель въ спальню.

Бывшіе туть не смьли тронуться сь мжста; Лассій сказалъ: “Јанжеронъ, что́ ты сдьвлалъ? Ты. пропалъ.»- «Что́ дылать! Слова воротить не можно; ожидаю всякаго несчастія, но не раскаиваюсь; я Игельстрома чрезвычайно почитаю: онъ не разъ мнъ дъллаль добро».

Черезъ полчаса времени, государь, вышедъ изъ спальни, подошель къ графу и, ударя его по плечу, сказалъ: “Langeron, vous êtes un bon enfant, toujours je me souviendrai de votre généreux procédé». (Ланжеронъ, вы добрый малый; всегда я буду помнить вашъ благородный поступокъ.) Я всегда за удовольствіе поставлялъ себъ это разсказывать. Сколько приносить сіе чести графу Ланжерону, столько, и еще болье, императору Павлу I; оно показываеть, что онъ умбъль иногда себя переработать и чувствовать благородство души. Еслибъ онъ окружень быль лучше, говорили бы ему правду и не льстили бы ему ивъ подлой корысти, приводя его на гнььь, онъ быль бы добрый государь. Но когда истина была, есть и будеть при дворж? 
Въ тоть день многіе получили ордена, въ томъ числь' и гражданскій губернаторъ Козинскій, ближній родственникъ князя Зубова.

9-е. Въ день своего отьһ̌зда, государь, отдавая приказъ Јассію, сказалъ: “Ты знаешь, что пока при пароль приказъ не будетъ отданъ, то никто не долженъ его знать; а этотъ долженъ быть отданъ послъ моего отьъзда). Погодя немного, онъ присовокупилъ: «Ну, Лассій, скажи правду, радъ ты, что я ъду?»-0чень. “Какъ?»-До сихъ порь вы думаете, что у нас'ь очень хорошо, а мы и очень не совершенны; такъ я хочу, чтобы вы уъхали, будучи въ таком' о насъ лестномъ мнъніи; а ежели бы остались долье, тогда бы увидъ̌ли болыше наши недостатки. «Правда, правда твоя), сказалъ государь.

Въ девять часовъ государь повхалт въ казанскій дъ̌ьичій монастырь, отслушаль литургію; поторую совершаль казанскій архіепископъ Амвросій ${ }^{238}$ ); по окончаніи оной, приложившись кь чудотворному образу казанской Богоматери, онъ заложиль соборную церковь въ оном'ь монастыръ, на которую пожаловаль двадцать пять тысячь рублей; заходиль въ келью къ игумень' (бывшей изъ дому князей Волховскихъ, казанскихъ дворянъ), и отправился въ путь.

По отъъздъ государя быль вахтъ-парадъ, на которомъ Игельстромъ, съ торжествующимъ видомъ строгаго инспектора, дъълалъ нъкоторыя взысканія и замьчанія; но посль, когда отданъ былъ при паролъ приказъ (адьютанть его егу оный принесъ), что вмъсто его инспекторомъ, военнымъ Оренбургскимь губернаторомь и шефомъ Рыльскаго полка назначен'ъ пожалованный изъ полковниковъ в'ъ генерал'ъмайоры, Н. Н. Бахметьевъ, а ему въдать только пограничную

238) Ащвросій Подобъдовъ, впосльдствіи митрополитъ новгородсній и с.-петербургскій, род. 30 ноября 1742 , ум. 21 мая 1818 г. M. I. 
часть, то онъ, прочтя сей приказъ, такъ ивмгенился въ лиць, что, я думалъ, сдълался епу ударъ. Полкамъ, бывшимъ на ревю, на другой день приказано выступить вт свои квартиры.

По прибытіи императора въ С.-Петербургъ, П. В. Лопухинъ ${ }^{239}$ ) пожалованъ свътльйшимъ княземъ, а дочь его камеръ-фрейлиной; она пользовалась особливою милостію государя ${ }^{240}$ ), а потомь выдана была замужъ за княвя Гагарина $\left.{ }^{241}\right)$.

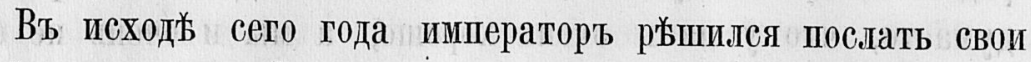
войска противу Французовъ, для чего генераль Розенбергъ выступиль изъ Россіи съ корпусомъ войскъ юь соединенію съ Австрійцами въ Италію; генераль ћорсаковъ ${ }^{242}$ ) в' Швейщарію; генералъ-лейтенанть Германъ въ сльдующую весну назначенъ быль со Флотомь сдълать высадку въ Голландію, съ Англичанами, подъ командой герцога Йоркcraro.

1799. Я отпросился въ отпускъ, и въ наступившешь 1799 году Богь благословиль меня супружествомь, блаженство юоего продолжалось двадцать два года и песть мьсяцевъ. Въ семъ же году пожалованъ я генераль-майоромъ и шефомь того же Уфимскаго полка, а графу Ланжерону данъ польь Ряжскій. Въ мат государь пожаловаль мнь командорство ордена Св. Іоанна Іерусалимскаго, съ ты-

$\left.{ }^{239}\right)$ Князь Петръ Васильевичъ Лопуухинь, дийствительный тайный совйтникь 1 класса и предсъдатель государственнаго совьыт, род. 1753 г., ум. 6 апрьля 1827 года, М. I.

${ }^{240}$ ) Княжна Анна Петровна род. 8 ноября 1777, ум. 25 апрћля 1805 года. $M . \pi$.

241) Князь Павель Гавриловичъ Гагаринъ, генерал'-адъютантъ, род. 8 января 1777 г., ум. 2 апрйля 1850 года. $M . ~ Л$.

242) Александрь Михайловичь Римскій-Корсаковъ, генераль отъ инфантеріи, род. 13 августа $17 b 3$ г., ум. 13 мая 1840 г. Войско выступило въ походъ за границу въ 1799 году. $M . J$. 
сячью рублями годоваго дохода. Служа въ турецкую войну и противу Поляковъ усердно и ревностно, былъ я въ несколькихъ сраженіяхъ, лица отъ непріятеля не отворачиваль и почти ничего не получиль. А за маршированіе на Арскомъ польъ и удачные батальонные выстрьлы получиль два ордена. Сего же года, въ исходъ ноября, по просьбь моей я отставленъ съ мундиромъ, что́ при государ'ь император'ь Павл's считалось большою милостію $\left.{ }^{243}\right)$.

Императорь, в'ь минуту своего гнъва, быль ужасенъ, но быль не злопамятенъ. Чувствуя уваженіе къ герою, графу Суворову, бывшему въ опаль, и зная, какую славу Россійское оружіе имъ можеть пріобрьсть, начальствуя Австро- Россійскою арміей противу всюду торжествующихъ Французовъ, онъ вызваль славолюбиваго старца изъ ссылки, и

243) Мы имъемъ в'ь Датскихз годахо Багрова-внука, сочиненіи C. Т. Аксакова любопытный портреть автора этихь Записокт во время пребыванія его въ УФь, въ 1793 году, когда онъ былъ полковникомъ. «Изъ военныхъ гостей я больше всъхъ любиль сначала Льва Николаевича Энгельгардта; по своему росту и дородству онъ казался богатырем'ь между цругими и къ тому же быль хорошъ собою. Онъ очень любиль меня, и я часто сиживаль у него на колььняхъ, съ любопытствомъ слушая его громозвучные военные разсказы и съ благоговйніемъ посиатривая на два преста, вись̌вшіе у него на груди, особенно на зонотой крестикъ съ округленными концами и съ надписью: “0чаковъ взять 1788 года 6 декабря). Я сказалъ, что любиль его сначала; это потому, что въ посльдствіи я его боялся; онъ напугалъ меня, сказавъ однажды: “хочешь, Сережа, въ военную службул? Я отвъчаль: «не хочу».- Какъ тебъ не стыдно, продолжалъ онъ: ты дворянинъ и непремънно долженъ служить со шпагой, а не съ перомь. Хочешь въ гренадеры? Я привезу тебъ папку и тесакъ)...... Я перепугался и убъжаль оть него. Энгельгардть вздумаль продолжать шутку и на другой день, видя, что я не подхожу къ нему, сказаль мнъ: «а, трусишка! Ты боишься военной службы, такь воть я тебя насильно возьму».... Съ әтихъ поръ я уже не подходилъ къ полковнигу безъ псобеннаго приказанія матери, и то со слезами»). 
столь уббдительнымь рескриптомъ, что тоть забыль всљ огорченія и черезъ часъ по полученіи того рескрипта выьхаль изъ своего заточенія. Богда онъ явился юь императору, государь въ ту же минуту надъ̌ль на него орденъ Св. Іоанна Іерусалимскаго; онъ паль къ ногамъ его, сказавъ: «Господи, спаси царя». А Павель, обнявъ его, сказалъ: “А ты поъзжай спасать царей».

Суворовъ, вскорь пожалованный въ званіе генералисспмуса, отправился къ арміи, а всльдъ за нимъ и великій князь Ћонстантинъ Павловичъ. Исторія наполнена его побъдами; всъ иностранные писатели и самые Французы не умолчали объ оныхъ. Я довольствуюсь сказать, что онь лучшихъ Французскихъ генераловъ во всъхъ м’̌стахъ въ нарядныхъ баталіяхъ разбилъ; всъ крьпости, занимаемыя Франщузами, взяль, и очистиль мен'ье нежели в'ь одну кампанію всю Италію, которую Французы завоевали въ три. Ћороль Сардинскій, . получивъ обратно Піемонтъ, наименоваль его своимъ cousin, родственникомб, а государь императоръ Павель пожаловаль его князем'ь Италійскищъ. Уже намъревался онъ перенести оружіе свое внутрь Франціи; но, по интригамъ Австрійцевъ, принужденъ былъ идти въ Швейцарію для соединенія съ Корсаковымъ, но тотъ уже быль разбить Массеною $\left.{ }^{244}\right)$. Лишенный всъхъ способовъ, кот0рыми объщали Австрійцы снабдить его, проходиль онъ сь своею арміей, поражая Французовъ, черезъ ть́ горы, гд'ь путешественники съ опасностію въ маломъ числь проъзжають. Государь, по справедливомъ негодованіи на Австрійцевъ, отовваль свои войска въ Россію.

Германъ въ Голландіи, не дождавшись высадки великобританскихъ войскъ, оть безразсудной запальчивости быль совершенно разбить.

244) Здъсь говорится о битвь при Цюрихь 14 и 15 сентября 1799 года. M. II. 
Генералиссимусъ князь Италійскій, cousin кородя Сардинскаго, графъ Александръ Васильевичъ Суворовъ-Рымнигскій, прибывъ въ С.-Петербоургъ, занемогъ, и чрезъ нъ̌сколько времени смерть прервала преславную жизнь его; государь почтиль память его трехдневнымъ трауромъ всей арміп.

Бонапарте, прибывъ изъ Египта и сдйыавшись гонсуломъ, собралъ русскихъ шльнныхъ, обмундироваль въ русскіе мундиры и препроводилъ ихъ къ императору Пав.лу. Ииператоръ тъимъ быль такъ восхищенъ, что съ Франщіей сдъылалъ миръ. ПІодъ гонецъ своего бурнаго царствованія, сдй.лалъ онъ съ Наполеонощъ союзъ, объъвиль войну Англіи и напъревался черезъ Киргизскую степь и Бухарію послать войска въ Индію. (Но цйль была завоевать Хиву). Уже корпусъ войскъ назначенъ быль выступить изъ 0ренбурга, двадцать тысячь Донскихъ ғазаковъ были уже близь Волги, кағъ внезапная смерть Павла I-го прекратила таковое гибельное предпріятіе.

Смерть приключилась государю оть апоплексическаго удара въ Михайловскомъ замгъ, 11-го марта 1801 года оголо полуночи. Царствованіе его продолжалось четыре года и четыре мъъсца, отъ роду же ену было сорогь шесть льъть, пять мъъсяцевъ и двадцать дней 245$) \ldots$.

245) Въ Соловецкомъ монастыръ былъ монахъ Авель, предсказавшій смерть императриц' Екатеринъ и потомъ императору Павлу, со всъьми об́стоятельствами краткаго его царствованія. За годъ до смерти императрицы, сей Авель, пришедъ къ настоятелю того монастыря, требоваль, чтобы довести до свъ̆дъ̆нія ея, что онъ слышаль вдохновенно гласъ, который долженъ онъ былъ ей объявить лично. По многимъ отлагательствамъ и затрудненіямъ, нагонецъ донесено было ей, и приказано было его представить: тогда онъ ей объявилт, что слышаль онъ гласъ, повел'вшій епу объявить ей скорую кончину. Государыня щриказала его заключить въ Петропавловскую крь̆шость. ПІо кончинъ государыни, императоръ повельъъ, освободя его, предста- 


\section{VII. Царствованіе Александра I ${ }^{246}$ ).}

1801 года 12-го марта императорь Александрь І-й Павловичт вступиль на престолъ. Болье всего обрадовало Россію, что въ манифесть о восшествіи своеиъ онъ возвъстиль, что будетъ царствовать по сердцу бабки своей великой Екатерины.

вить къ нему; когда онъ ему предсказалъ, сколько продолжится его царствіе, государь въ ту же минуту приказалт его опять заточить въ крњпость. Смерть однакожъ исполнилась въ назначенный срокъ. При вступлени на престоль Алегсандра I, онь быль освобожденъ. За годъ до нападенія Французовъ, Авель предсталъ предъ императором', и предскаваль, что Франщузы вступять въ Россію, вовьмутъ Москву и сожгуть. Государь приказаль его опять посадить въ кржпость. По изгнаніи непріятелей онъ быль выпущенъ. Сей Авель посль того быль долго въ Троицко-Сергіевой Лаврь и Москвъ; многіе изъ моихъ знакомыхъ его видъ̆ли и съ нимъ говорили: онъ быль человъкъ простой, безь малъйтаго свъдънія и угрюмый; многія барыни, почитая его святымъ, ъздили къ нему, спрапивали о женихахъ ихъ дочерей; онъ имъ отвтучаль, что онъ не провидецт, и что онъ тогда только предсказывалъ, когда вдохновенно было велйно ему, что̀ говорить. Съ 1820 года уже болье никто не видалъ его, и не извьстно куда онъ дъвался.

246) Записки Л. Н. Энгельгардта доведены до времени кончины императора Александра I, но уже не представляють того интереса, которымъ отличаются первыя ихь главы. Съ 1801 года автор'ь рьдкко является въ нихъ дй̆ствующимь лицомъ, а потому Записки его лишены по большой части жизни, которая такъ ярко выражается въ описаніяхъ событій, гдж Л. Н. Энгельгардтъ является участникомъ или свидъ̆телемъ. Записки его о временахъ царствованія Александра I преимущественно состоятъ изъ сухих' перечней сраженій и тому подобныхъ обстоятельствъ, изложенныхъ по реляціямъ и разсказамъ. Эти соображенія побудили нась выбрать только немногое из' Записокт 1801-1825 годовъ п напечатать т0, что можеть быть публликовано изъ разсказовъ о малоиввљстныхь обстолтельствахъ, а также изъ случаевъ частной жизни Л. Н. Энгельгардта, гдъ выступаетъ его оригинальная, правдивая дичность. Н. II. 
Я съ женой въ началъ сего мъъсяца пожхалъ изъ Москвы въ приданыя ея казанскія деревни, но за распутицей принуждент былъ завесновать въ Нижнеиъ-Новгородъ. Случилось мнґ быть у княвя Грузинскаго, какъ ввечеру, часовъ въ девять, вдругъ вббъгаетъ почтмейстеръ въ разстроенномъ видъ, вызываетъ хозяина въ кабпнетъ; пробывъ тамъ съ минуту, онъ съ поспъшностію отправился обратно. Князь отвель меня къ сторонеъ и сказаль: счто про'ххаль курьерь, въ казанскую адмиральтейскую гонтору, съ манифестомъ императора Александра о вступленіи его на престоль, что подорожная у того гурьера печатная по уғазу Александра I». Время было критическое. “Отчего же нътт съ манитестомъ курьера въ Нижній»? сказаль я князю.- Пожалуста, никому не говорите: изъ того могутъ произойти ужасныя посльдствія». На другой день поутру, нижегородскій купецт Костроминъ, щришедъ ко мнъ̌, сказалъ, что онъ уже дня три ожидаль сего интереснаго и пріятнаго извъстія. Несмотря на скрытность, весь городъ зналь о прољздљь того курьера, и всъ были въ ужасномъ недоумъัніи. Уже на третій день, в’ полночь, услышанъ былъ заунывный звонъ соборнаго колокола. Губернаторъ прислалъ ко мнъ объявить о полученіи манифеста, предлагая мнъъ прибыть въ соборъ кіъ присягеи: тогда только отлегло на сердцъ. Причина замедленія сенатскаго гурьера была та, что онъ сь симъ манифестомъ посланъ быль по пути, сперва въ Ярославль и Кострому, а потомъ уже прибыль въ Нижній, и отправился въ дальнъйшія губерніи.

Радость на другой день была общая: другъ друга поздравляли и обнимали, какъ будто Россія была угрожаема нашествіемъ варваровъ и освободилась.

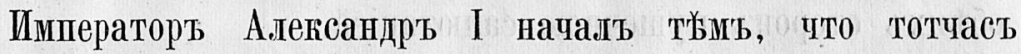
заключиль ииръ съ Англіей, которой флотъ подъ командой Нельсона подступиль къ Ревелю. Послаль повельніе Дон-

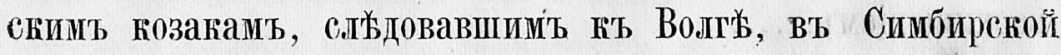


губерніи, возвратиться на Донъ; въ прошломъ царствіи всъххъ сосланныхъ въ Сибирь и содержащихся въ крж̌постяхь повель̈ль освободить; возобновиль совъстные суды, уничтоженные Павломъ.

Вотъ что́ разсказывалъ мнъъ Александръ Дмитріевичъ Балашевъ (въ сіе время былъ онъ генералъ-майоромъ, въ Ревелгы военнымъ губернаторомъ и командующимъ сорока-тысячнымъ горпусомъ прибрежнаго войска). Ћогда англійскій флоть подошель къ Ревелю, а нашъ флоть за льдомъ не могъ выйдти на рейдъ, то произошла такая тревога, что не знали, что́ и дъълать. Адмираль Нельсонъ прислаль къ Балашеву просить повволенія наливаться водой. На это Балапевъ отвйчалъ, что не только онъ не можетъ то повволить, не ежелибы можно было, онъ бы лишиль его и той воды, которую его флоть имъеть. Нельсонь прислаль вторительно сказать, что онъ удивляется таковому отказу, когда миръ заключенъ между объими державами, въ удостовъреніе чего пріъдетъ къ нему въ крьпость безъ оружія со всьми флагманами и капитанами кораблей. Балашевъ просилъ сдызлать ему сію честь, а самъ съ донесеніемъ отправиль къ императору курьера, готорый разъъхался съ посланнымъ оть государя къ Балашеву съ извъстіемъ о заключеніи мира.

Нельсонъ на шлюпкахъ, со всъми имъ объявленными, прибыль въ Ревель, и Балашеву рекомендовалъ своихъ подчиненныхъ: такой-т0-первый атақоваль при Абукирь французскій Флотъ, такой-т0-первый прошоль чрезъ Зундъ, и т. д. Балашевъ угостилъ гостей кақъ можно лучше, посль чего отправились они на свой Флоть, и какь скоро оный налился водою, то и отправился обратно съ положенною съ об̆ъихъ сторонъ пушечною салютаціей.

Въ августъ̌ государь императоръ прибыль въ Москву короноваться. Народъ встрьтиль его сь превеличайшимъ восхищеніемъ...... 
Торжество воранаціи было веливольпно: Александрт, молодой, преграсный мущина, въ горонъ и мантіи, былъ идеаль монарха, объщавшаго быть образцомъ всъхъ государей и отцомъ своихъ подданныхъ.....

Въ царствованіе пиператора Александра I-го многія изданы благотворительныя узаконенія: уничтожена вовсе тайная канцелярія, учреждены министерства, университеты

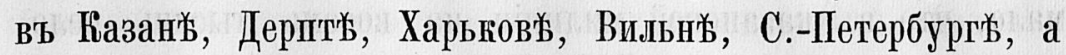
Московскій университетъ преобразованъ по особому новому плану; въ Посквъ учреждена медико-хирургическая академія, въ Царскомъ Сель лицей, въ Петербургь⿱ императорская публичная библіотека; возстановлено свободное рыболовство по Каспійскому морю, позволено всякому званію людямъ пріобрътать земли, а помњщикамъ цълыми селеніями отпускать крестьянъ, именуя ихъ вольными хль̌бопашцами; учреждено управленіе водяныхъ и сухопутныхъ сообщеній; учрежденъ для дворянъ 24-хъ ль̌тній банюъ; учреждены военныя поселенія (которыя, дай Богъ, чтобт для Россіи по времени не были пагубны). Грувія покорилась добровольно подъ Россійскую державу. Россія пользовалась миромъ и благоденствіемъ подъ кроткимъ скипетромъ государя Александра І-го до 1805 г.

Изложеніе первой противъ Франиузовъ войны, сдълланное отиасти по реллиілмь и разсказамб, авторь заключаеть словами: "Аустерлицкая баталія сдъ̌лала великое вліяніе надъ характеромъ Александра, и ее можно назвать эпохою въ его правленіи. До того онъ быль кротокъ, довърчивъ, ласковъ, а тогда сдъзлался подозрителенъ, строгъ до безмърности, неприступенъ и не терпъљъ уже, чтобы кто говорилъ ему правду; къ одному гр. Аракчееву им'љљ полную повъренность, который по жестокому своему свойству приводиль государя на гнйвъ и тйиъ отвлекъ отъ него людей, истинно любящихъ его и Россію».

1806. Государь издалъ манифестъ 0 войнь̌, учредиль 
милицію, раздъљля Россію на семь областей; даль власть главнокомандующимъ оными наравнъ съ главнокомандующимъ за границею. Я былъ избранъ казанскимъ дворянствомъ въ губернскіе начальники. Конечно, милиція сама собой не могла дьйствовать: 1-е, не было оружія, хотя дворянство и всякаго званія люди жертвовали ружья и сабли (а при томъ знатныя суммы денегъ); но онаго было столь мал0, чт0 въ казанской милиціи на восемь тысячь человъћь ружей не было и ๖00. При томь еще они были разнокалиберныя, охотничьи, безъ штыковъ, для чего ворружены были пиками, наподобіе штыковь. 2-е, дворянство, вступившее въ милицію поголовно, давно уже отстало оть военной службы; иные состарьлись, другіе обльнились, и много было такихъ, которые почти никогда не служили въ военной служобъ, а только въ гражданской. Однакоже ратники отчасти научены были строиться безъ вытяжки, маршируя ровняться; собранныя ружья отданы были по частямь, и люди научены были заряжать и стрьлять въ цьљль. Ежелибы милицію подвигали частями ю действующей арміи и замъщали ратниками убыль, въ сраженіяхъ посль̌довавшую, вмь̌сть съ прочими размьљщенными по полкамъ, то армія всегда была бы въ комплекть. Въ таковомь видеь милиція большую могла бы принести пользу, а особливо въ своихъ границахъ.

Ћогда уъ̌здные начальники принимали ратниковъ, то я предиисаль, чтобъ они отм'ьчали въ спискахъ тъхъ, которые были по промыслу стрблки, то-есть: въ Казанской губерніи, въ Царевококшайскомъ и Козьмодемьянскомъ уььздахъ, Черемисы промышляють стрбляніемъ дичи, и закупщики изъ Москвы по заморозамъ покупають оную въ большомъ числь. Также сіи Черемисы бьють дробовиками бћлокъ, и чтобы не испортить шкуру, мътять ей въ носъ; охотники сіи ходять поодиначкъ на медвъдей сь однимъ ружьемъ и рогатиною. Rогца э представиль списки набрашнымь рат- 
никам’ь, объъзжавшему VII-ю область главнокомандующему князю Юрію Владиміровичу Долгорукому, то онъ, увидя отмътку: «по промыслу стръљоњъ), спросиль меня, что́ это значитъ? Когда я ему поясниль, то онъ сказалъ: это будутъ егеря лучше тъхъ, которые въ ариіи. По поводу чего онъ представиль имшератору, чтобъ изъ ғаждой губерніи его области сформировать ивъ таковыхъ по батальону стрьыловъ и отправиль въ армію, на что́ государь изволиль указать. Я сөормироваль тоть батальонъ етрълюковъ и отправилъ Въ Смоленскъ; тамъ его обпундировали, дали негодныя ружья и начали учить струьлять, приґладываясь поо принятому образу регулярныхъ войскъ, виъсто того чтобъ оставить

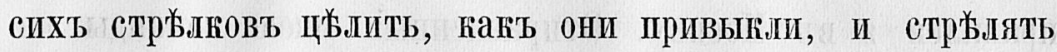
безъ промаха; а потому они не могли уже оказать ту пользу, ғакой я отъ нихъ ожидаль.

Далпе сльдуетг такое же изложеніе войньл 1806 и 1807 иి., изг коего напечатано образованіе милииіи, въ которой авторг быль дљииствуюиимг личемг; потомб описьваютсл: Тильвитскій мирг, потьздка Александра въ Эрфуртг для свиданія сг Наполеономг и заключеніл, по словамг автора, “Уудейской их'ь обоюдной дружоб, при чемъ быль и несчастный ощипанный король Прусскій);

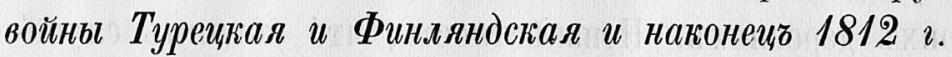

Милицію велььно распустить, съ позволеніемъ помњщикамъ и казеннымъ поселянам' взять обратно тьбхъ ратниковъ, коихъ пожелаютъ, а которыхъ пожелають оставить на службъ, т我ъ дать зачетныя рекрутскія квитанціи; оставшимся на службъ сдъ̆лать разборъ: рослыхъ и лучшихъ людей въ гвардію, потомъ в'ъ армію, потомъ в'ъ гарнизоны, потомъ въ гржпостную работу, а уже совсъиъ неспособныхъ-въ пожарную кощанду. Всъмъ служившимъ въ милиціи дворянамъ даны золотыя медали на владимірской ленть', и позволено имъ носить милиціонные мундиры съ отличіемъ, кағія мъъста они занимали; многіе награждены орденами, 
въ числь которыхъ и я получилъ орденъ Св. Анны 2-й степени, украшенный алмазами.

Изъ Казанской милиціи поступило въ гвардію, армію и гарнизоны болье 4 тысячъ человъьь, на оружейный Ижевскій заводъ Вятской губерніи, учреждавшійся г-мъ Дерябинымъ, 2 тысячи человь̌къ. Назначенныхъ въ армію и гарнизоны приказано было отправить на подводахъ въ Кавказ-

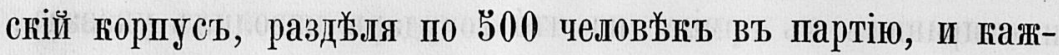
дую при двухъ начальникахъ изъ дворянъ, служившихъ въ милиціи, и съ объщаніемъ, которые довезутъ исправно, наградить ихъ сльдующими чинами.

Но сдачь отчета въ людяхъ, суммахъ и провіянт年, отправился я въ Москву. Отправленныя мною гоманды на Ћавказъ не скоро доставили мнћ квитанціи въ доставленіи ратниковъ, ибо задержаны были, при воввращеніи, въ карантинахъ, по случаю бывшей тамъ заразы; между тьыъ военный министръ, графъ Аракчеевъ, въ вьдомостяхъ обћихъ столицъ объявилъ благодарность чиновникамъ, отводившимъ ратниковъ, что они исправно доставили ихъ, почти всъх' здоровыхъ, и ни одного изъ нихъ не бъжало.

1812. Я былъ въ Казани, какъ въ Московскихъ Въдомостлхг увидъьљь 0 ввятіи Смоленска. Отецъ мой былъ тамъ въ своихъ деревняхъ. Неизвъьстность, что́ съ нимъ случилось, чрезвычайно меня тревожила. Между тььмь поъхаль я съ моимъ семействомъ въ Симбирскую губернію къ свояченицъ моей Л. П. Чирковой, жившей отъ Симбирска во ста верстахъ. Тутъ получены были въъдомости о славной Бородинской баталіи, одержанной М. Л. Кутузовымъ, посланнымъ принять начальство надъ всею арміей, настояніемъ императрицы Маріи, матери государя, и всъхъ тамъ бывшихъ, преданныхъ любезному нашему отечеству ${ }^{247}$ ).

247) Иные увъряютъ, что генералы, видя несогласіе главнокомандующихъ цвухъ армій, послали просить государя прислать для гомандованія оными Кутузова, кагь старшаго генерала во всей арміи. 
Јдачная его баталія, а болье еще, что онъ командовалъ арміей, оживила всъхъ Русскихъ. Ожидали, что Наполеонъ, принужденъ будучи въ первый разъ въ своей жизни отступить къ прежней своей позиціи, оставя поле сраженія, будетъ ретироваться. Тъ̌мь больье обнадежены были, что Ћутузовъ въ реляціи сказалъ, что на другой день пойдеть атаковать Французовъ.

Посланъ былъ отъ насъ за почтою въ Симбирскъ нарочный, котораго ожидали съ нетерпъніеиъ; но цъљыы сутки человъькъ не пріхзжалъ, и прівхаль уже черезъ день, сказавт, что почта не приходила. Тогда поняли мы, что случилось важное несчастіе. Я уговорилъ свояченицу жхать съ нами въ Казань, гдъ скоръе можно получать извъсстія и по онымъ предпринять нужныя вообще меры. Надобно было пробзжать деревню на большой Московской дорогъ, бывшую Р. Е. Татищева, у котораго мы имъли ночлегъ. Туть мы увъ̈домились, что сенатъ и многія мъьста правленія изъ Москвы выпровождены, частные люди, которые могли, выьхали, и туть же увидъ̌ли изъ Москвы проъзжающую въ свои деревни графиню Орлову со многими съ нею бывшими.

На другой день хозяинъ нашъ получилъ письно отъ Волкова, бывшаго въ Москвъ полицеймейстеромъ, повергшее насъ въ неизъяснимую горесть: онъ въ ономъ увъддомлялъ, что наша армія ретировалась черезъ Москву, и Наполеонъ въ тотъ же день въ нее вступилъ, предалъ пламени древнюю нашу столицу, и кромъ сть̌нъ каменныхъ домовъ и груды кирпичей въ Москвъै ничего не осталось.

Прибывъ въ Казань, мы уже тамъ нашли сенатъ московскихъ департаментовъ, институты Екатерининскій и Александровскій, чиновниговъ и воспитанниговъ воспитательнаго дома, ломорардъ онаго съ вещами и суммами опегунскаго совъ̌та, и множество всякаго званія жителей московскихъ. Нъготорые изъ нихъ выбрались въ самый день сдачи Москвы; разсказывали они разные анекдоты, одинъ 
другаго печальнъе, и что до самаго Владиміра дорога была покрыта экипажами, ьдущимъ и идущимъ народомъ. Всъ были мрачны, унылы и горевали по отчизнъ, забывъ 0 потеръ своей собственности, оставленныхъ въ Москвъ домахъ съ имуществомъ, въ числь' поторыхт и я того же лишился.

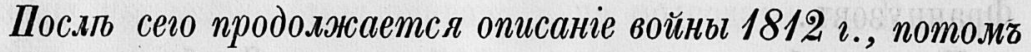
1813 и 1814 годовб, которое авторг заключаетв сльдуюшими словами: “Тогда императоръ былъ во всей своей славґ:

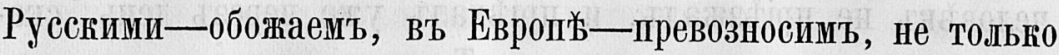
какъ побъддтель, но какъ величайшій политикъ, велик0душный и скромный благотворитель рода человь̌ческаго; всъ несли емг въ дань свои души и сердща. Со времени Аустерлищкаго сраженія, за несправедливый гнъвъ его к’ Кутузову и оскорбленіе другихъ генералов'ъ понапрасну, онъ отвлекъ сердца подданныхъ своихъ, но посль торжества его все было забыто. Ожидали, что миръ доставитъ Россіи благоденствіе, тто императоръ будетъ больье заниматься внутреннимъ устройствомъ государства, тто онъ, увидя настоящую ц末љьь военной службы, не будеть заниматьсп мелочною; но въ посльъдствіи оказалось противное, и военная служоа сдйлалась несноснъе и труднъе; отъ генераловъ требовали то, что́ требовалось отъ низшихъ классовъ офицеровъ.»

1813. Пріятныя извъьстія 0 побъдах'ъ узналъ я въ Москвъь, въ проъздъ къ отцу моему, въ Смоленскую губернію. Нельзя

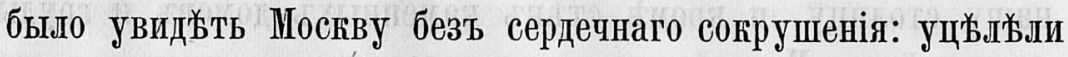
только въ Креиль нъ̌которыя зданія, Китай-городъ (но не Гостиный дворъ), улицы: Тверская, Дмитровка, Петровка, часть Лубянки, Покровка, Мясницкая, Кузнецкій мость, Большая Мљщанская и Запасный дворецъ. Остальное все было выжжено, и кое-гдъ оставались небольшіе домики.

По Смоленской дорогъь только что начали выстраиваться

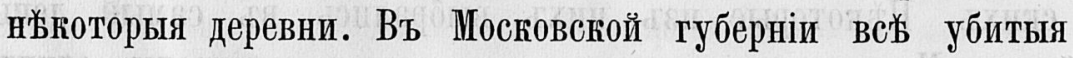
твила были сожжены, а въ Смоленской до самаго города не 
надобно было спрашивать о дорогъ, а сльдоовать по большимъ могиламъ, бывшимъ по объимъ сторонамъ, въ самомъ близкомъ разстояніи одна отъ другой. Города: Гжатскъ, Вязьма, Дорогобужь и самый Смоленскъ представляли печальное зръллище; стьныа въ Смоленск光 во многихъ мъстахъ была подорвана.

Отца моего, въ его деревнъ Рославльскаго уъзда, нашел'ь, благодареніе Богу, здороваго; во время нашествія непріятелей онъ укрывался въ БЪльскомъ уъздъ, на границъ Псковской губерніи. Смоленское дворянство почти все на то время вы'ъхало въ ближнія губерніи. Оставались: родственникъ мой Павель Ивановичъ Энгельгардтъ и Шубинъ, ивъ побужденія, чтобы вредить непріятелю. Когда они были Французами схвачены и принуждаепы присягнуть Наполеону, т0 за отрицаніе отъ сего были разстръляны; жены ихъ, за върность мужей, государемь были щедро награждены.

1814. Я былъ въ Москвъ, когда получено офиціяльное извъстіе о взятіи Парижа, отреченіи Наполеона и вступленіи на престоль Лудовика XVIII. Торжество въ опаленной столицъ было восхитительно; безъ всякаго приказанія, вся Москва нбъсколько дней была иллюминована; одинъ предъ другимъ выдумывали эмблематическія прозрачныя картины. Дворянство сдъзыало особый праздникъ въ домъ Полторацкаго,

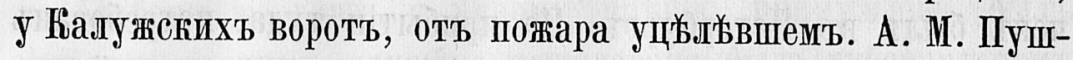
кинъ сочиниль Прологъ, соотвъ̌тствующій сему торжеству; княгиня Вяземская со многими дамами и дъвицами представляли оный; бюсть государя императора былъ поставленъ на пьедесталь, богато и искусно украшенномъ, охраняемый и увънчанный геніями, и къ нему хоръ относился. Надпись на пьедесталь сочинена была княземъ Вяземскимъ:

Мужъ твердый въ бйдствіяхт и скромный побъдитель!

Кагой вънецъ ему? Какой ему алтарь?-

Вселенная! пади предъ нимъ: онъ твой спаситель;

Россія! имъ гордись: онъ сынъ твой, онъ твой царь! 
Для народа поставлены были амбитеатры съ балансерами и разными фогусниғами; иллюминація съ эмблематическою картиною была превосходна; по окончаніи Пролога сожженъ былъ фейерверкъ, а потомъ балъ продолжался до пяти часовъ утра.

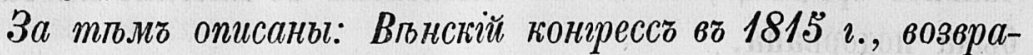
шеніе Наполеона сб Эльбы и посльдуюшіл событіл внтьи-

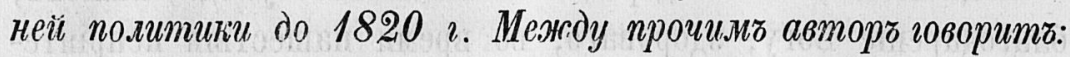
Въ 1817 г. устроены военныя поселенія въ Новогородской, Бљ,лоруской, Воронежской и Харьковской губерніяхъ, по поводу чего происходили безпокойства, а особенно за бритіе бородъ, но строгими мерами все приведено въ порядогъ. Потомг разсказываетсл о прибытіи вг 1818 थ. Двора вб Москву, о пребывании короля Прусскало, о заложеніи храма Спасителя и прочихь общеизвьстныхь собьттілхв.

1820. По случаю смерти моего зятя Вязитинова, за нъ̌сколько передъ оною мъсяцевъ пожалованнаго графоиъ, пріьхалъ я въ Петербургъ нав Бестить овдовъъвшую сестру мою ${ }^{248}$ ) и записать сына моего въ гвардію. Графъ Сергъй Кузмичь Вязмитиновъ былъ изъ незнатнаго и небогатаго дворянства Курской губерніи, Рыльскаго уъздда; записанъ быль на службу почти ребенкомъ въ армейскій польъ, тамъ квартировавшій, сержантомъ; вскоръ тотъ полюъ для содержанія караула назначенъ былъ въ Петербургъ. По прибытіи туда, потребованъ былъ оть сего полка въ канцелярію президента военной коллегіи граша 3. Г. Чернышева, унтеръ-ошицеръ, знающій хорошо писать; Вязмитиновъ былъ для сего наряженъ. Остротой, прилетіаніемъ п поведеніемъ своимъ снискалъ онъ благосклонность правителя канцеляріи, который, видя его дарованія, отличалъ его и обращался съ нимъ ласков0; по поводу сего онъ ознакомился и съ графскими адъютантами. Праздное время

248) 0 Вязмитинов Һै п супруге его см. въ Запискахъ Д. Б. Мертваго стр. $83-97$ и 106 . II. Б. 
отъ должности употребплъ онъ на изученіе франщузскаго языка, въ которомъ по времени быль очень силенъ, занялся чтеніемъ касательно разныхъ наукъ. Умъ его, трудолюбивый и острый, доставиль ему то, чему ръдкіе могли выучиться, получа рачительное воспитаніе. Онъ пристрастился юъ музыкь, и какъ въ штать графа нькоторые были музыканты, то по охоть̌ своей скоро выучился на віолончели, и игралъ на ономъ инструментё, не какъ артисть, но какъ охотникъ и знатокъ, очень хорошо. Вскорь и графъ Чернышевъ его узналь, сднлалъ его своимъ Флигель, а потомъ и генеральсъ-адъютантомъ. Онъ былъ при немъ пятнадцать льтть и управляль уже его ганцеляріей и всъии дъзами. За учрежденіе Бълорусскихъ губерній особенно онъ былъ графомъ рекомендованъ, за что императрица полаловала ему въ Бьлоруссіи 800 душь. По истеченіи шести льть вь званіи генеральсь-адъютанта при фельдмаршальь, пожалованъ онъ полковникомъ, и данъ ему Вологодскій мушкетерскій полкъ, который онъ довель до того, что полкъ этоть служиль образцомь въ арміи. Потомъ сформироваль онъ Сибирскій гренадерскій польъ, также доведенный ищь до совершенства. Обратиљь на себя вниманіе фельдмаршаловъ: грапа Румянцева и свъттльйшаго княвя Потемкина и сталь иввъстень самой императрицй. По старшинству пожалованъ онъ быль генераль-майоромъ; по бользни же глазь и худому зрънію принужденъ быль оставить военную слуябу; пожалованъ быль губернаторомъ въ Могилевъ, а потомь сенаторомъ. Императрица, почитая пость генералъ-губернатора УФимской губерніи важнымъ, ғасательно Башкирцевь и Оренбургской линіи, возвела его въ сіе достоинство, при которопь онъ и оставался до вступленія на престоль Павла I, поторый, оттуда его вызвавт,

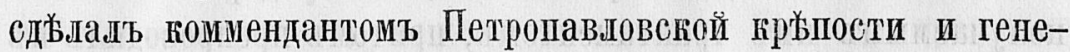
ралъ-кригсь-коммиссаромь и пожаловаль тысячу душъ въ Минской губерніи. Въ концй царствія его он'ъ быль въ опаль. Императорь Александрт пожаловаль его генераломь 
отъ инфантеріи, вице-президен'гощъ военной юолегіи; при учрежденіи министерствъ, военнымъ министромъ и главногомандующимъ С.-петербургскииъ, но посль̌ Аустерлицкой баталіи на него прогнъьвался и отставиль даже безь мундира. Мъсто его заступиль графъ Аракчеевъ, который, по нькоторымъ обстоятельствамъ, быль личнымъ его непріятелемъ. Но къ чести графа Аракчеева, и можно сказать, въ одномг только семг случаль, онъ показаль себя незлобивымъ. Черезъ двъ недъьли по пріемь сей должности онъ подаль государю просьбу объ увольненіи его оть служоы. Государь удивился, и спросиль своего любимца, какая тому причина? Тоть ему отвиччаль: “ћогда ваше величество отставили съ такимь позоромъ Вязмитинова, то всъ думали, равно какъ и я, что онъ найденъ вами въ нераченіи, изобличенъ въ злоупотребленіи и разстройствь въ дъ̌̆лахъ; но когда я приняль его должность и вопель въ подробность дйль, то увидёль, что коллегія и департаменть, равно и канцелярія главнокомандующаго, все было въ совершенномь порядкь: не только не замьттиль влоупотребленія, но напротивь я увидељљь рьдкое его безкорыстіе; а потому судя, что ежели такой человъкъ, каковъ Вязмитиновъ, служа всегда съ такою честью столь долгое время императриць-бабют вашей, императору-родителю вапгему и вашему величеству, отставлень тақь позорно, то я и всякій другой должны ожидать такой же участи, безь всякой причины, по одному только ваиему капризу. Для чего и прошу меня отставить, и я иначе не соглашусь служить, если не отдадуть должной справедливости Вязмитинову». По поводу сего государь въ приказъ объявиль, что Вязмитиновъ отставленъ, по просьбь его, сь пундиромъ и всъпь получаемымъ имъ трактаментомъ, притомъ препроводиль къ нему лестный рескрипть. По нъкоторомъ времени помъстиль государь его въ государственный совютть и возвратиль къ нему свою довъренность: въ началь 1812 года опять сдъ- 
лаль его главнокомандующимъ въ С.-Петербургъь и министромъ полиціи, пожаловавъ ему аренду на двъннадцать льътъ, приносящую болье сорога тысячъ рублей ежегоднаго доходу. Возвратясь, по взятіи Парижа, онъ пожаловалъ ему орденъ Св. Андрея, а сестру мою гавалерственною дамой ордена Св. Екатерины 2 класса; неоднократно жаловалъ онъ его деньгами и одинъ равъ сто тысячъ рублей подъ видомъ на экстра-ординарные расходы, безъ отданія въ оныхъ отчета, не задолго передъ его кончиной и графскимъ достоинствомъ. Онъ во всю свою жизнь и службу не имьлљ и не искалъ ни у гого протекціи, пріобржтая чины и все единственно своею ревностною службой. Каґъ онъ сверхъ родства былъ мнъ благодъттель и дружески ко мнъ расположенъ, то я за долгъ почелъ изложить его біографію. Сюончался онъ семидесяти восьми л安т посльь пятидесяти льъть службы. Похороны его были великоль̆пны: сопровождали его гроб́ъ весь сенатъ и войска до Александро-Невскаго монастыря, гдъ̌ онъ и погребенъ. Государь посьитиль два раза вдовствующую его супругу, мою сестру, и пожаловаль ей по жизнь все, что́ получаль покойный Сергъ̌̆ Кузмичъ....

Войска наши, бывъ долгое вреня въ чужихъ краяхъ и видя всъ государства во всей Европь управляемыми законами и конституціями.... заразились духомь времени. Молодые люди уже въ 1818 г. составили тайныя общества

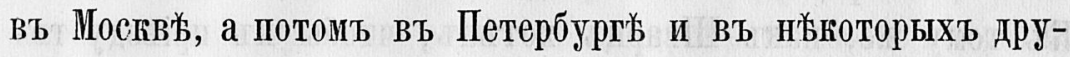
гихъ губерніяхъ; общества сіи отчасти были извъстны ицператору, но онъ ихъ пренебрегъ, дальньйшихъ изысканій не дълалъ, а искра тльзыась. Самые нижніе чины почувствовали разность въ обращеніи и содержаніи чужеземныхъ войскъ, а притомъ и сами содержимы были за границею иначе нежели вт Россіи. Тамъ оть нихъ не требовалось изнурительной вытяжки и не занимали ихъ безпрестанными ученіями, довольствовали ихъ лучшего пищею, и спали они 
на тюфякахъ; возвратясь же въ Россію, рйдко для постели имъљли хорошую и свъ̌жую солому, ьли пустую кашицу и очень рьдко по небольшой порціи мяса; требовалась оть нихъ чистота и опрятность; въ узкихъ мундирахъ безъ отдыха ихъ учили, что́ и пропввело между ними ропотъ. Тағъ какь гвардейской Семеновскій полюь, котораго, будучи насльдникомт, пмператорь быль шефомъ.... оть прочихъ полговъ гвардіи въ экзерциціяхъ отсталь, то, передъ отъьъздомъ императора за границу на конгресст, опредёленъ юомандиромъ онаго полка полковникъ Щварцъ, служившій всегда въ арміи, не имжвшій пикакото воспитанія, но отличавшійся чрезвычайною строгостію по фронтовой служоъ. При отъъзды государь сказаль ему, что онь надьется по возвращеніи своемъ не только найти Сененовскій полкь сравнивпимся съ прочими полками, но что оный, какь первый въ гвардіи полкъ, будеть во всемъ лучшій. Семеновскій полкъ наполненъ былъ офицерапи изъ лучшаго дворянства, людьми воспитанными и гордящимися предъ прочими, находясь въ любимомь полку государя. Солдаты были выбраны изъ всей арміи лучшіе. Уже самое опредъљленіе Шварца иуь было тягостно: какъ, армейской полковникъ будетъ ими командовать? Его грубое и неблаговоспитанное обращеніе еще болье противъ него вооружило. Офищеры говорили между собою, но такъ чтобы нбъоторые нижніе чины могли слышать: “Шварцъ можеть командовать скотами, а не людыми». Ћъ тому же, какъ Шварцъ хотьль, чтобы къ прівзду государя представить полкъ во всей исправности, то и сталь безпрестанно учить, безь отдыха. По обыкновенію полки гвардіи въ ль̌тнее время по частямь отпускались работать на биржу, гдъ они заработывали много денегъ для улучшенія своего содержанія и qтобы чище одьваться. За безпрестаннымъ ученіемъ Семеновскіе не имъли на то времени, да и Шварцъ ихъ не отпускаль, что̀ и обратило на него общее польа негодованіе. Всякой день требоваль онъ, 
чтобы фельдФебеля изъ каждой роты приводили нъ нему по десяти рядовыхъ во всей аммуниціи, и чтобы перевязи къ сумамъ и тесакащъ были чисто выбълены; самъ ихъ училъ ружейнымъ пріемамъ и маршированію; за мальйшую ошибку наказывалъ ихъ строго, къ чему они не привыкли; но еще болъе несносно имъ было, что онъ ихъ ругалъ поносно и непристойными словами, плеваль имъ въ лица и пр. Ежели онъ гого из' нихъ наказываль строже другихъ, офицеры тағовымъ давали деньги, браня Шварца. Въ одинъ день лейбъ-роты фельдфебель привель по обыкновенію 10 солдатъ съ худо-выб̆ъленною аммуниціею. Шварцъ его выгналъ, приказавъ привести другихъ, а если они будуть также неопрятны, то обњщаль дать 500 лозановъ; а онъ уже имъљлъ три нашивки, овначавшія 25-л宛нюю службу и орденской знакъ, по которому освобождался отъ ть̌ылеснаго наказанія. ФельдФебель, пришедъ въ роту, сталь наряжать другихъ солдатъ, но тъь ему сказали: что имъ аммуницію нечъ̆мъ выбълить, что какъ они на работу не отпускаются, то и не на что купить ни мъљу, ни клею, ни мыла. Тогда фельдФебель сказалъ: «такъ мн火ь придется принять 500 лозановъ, ежели не приведу въ такоџъ видъ, въ какомъ полковникъ приказалъ». Вся рота закричала въ голосъ: «мы до того никаґъ не допустимъ». Каґъ онъ ни упрашивалъ, чтобы перестали противиться, но они и слушать не хоть้ли. Фельдфебель пошель доложить ротному гомандиру капитану Кашкарову объ ослушаніи роты. Кашкаровъ пришелъ къ роть, сталь увъљщевать, но солдаты отвжчали: «Ваше высокоблагородіе, мы не ослушиваемся, но намъ нечжиъ бълиться, какъ вамъ угодно». Капитанъ донесъ о тощъ полюовнику, а этотъ поъхалъ доложить великому внязю Михаилу Павловичу, какъ бригадному командиру. Великій князь прибылъ въ казармы и нъ̌которыхъ наказалъ; но солдаты въ одинъ голосъ и его высочеству сказали, что они не выходять из'ъ должнаго повиновенія, но докладываютъ, что они не имъюютъ де- 
негъ на что выбълиться и просять его высочество сдълать инспекторскій смотръ, по которому начальство усмотритъ варварскіе съ ними поступки полковника. Великій князь повхаль къ командующему гвардейскимт корпусомъ генералъ-лейтенанту Васильчикову, который приказаль всю роту въ шинеляхъ привести въ экзерциргаузъ, гдъ собранъ былъ вооруженный гвардейской Павловской полкъ. Какъ скоро рота была приведена, то тотчасъ полкъ ее окружиль и отвель въ Петропавловскую кръпость со всьми оФицерами подъ аресть. На другой день 1-й баталіонъ Семеновскаго полка долженъ быль вступить въ карауль. За недостающимъ числомъ людей, приказано было нарядить оныхъ изъ другихъ баталіоновъ. Весь поль въ шинеляхъ вышель безъ ружья на плацъ-парадъ и требоваль 1-ю роту, какъ составляющую часть полка, безъ которой отрекались идти въ карауль. ОФищеры всячески уговаривали рядовыхъ, чтобы перестали бунтовать, но они, снимая передъ ними фуражки, отвъ̌чали съ въжливостію одно и тоже. Нькоторые ворвались было въ домъ Шварца, но онъ скрылся. Вскоръ дошло объ этомъ до великихъ князей и корпуснаго командира. Они прибыли къ полку на плацъ-парафдъ, спрашивая 0 причинъ ихъ бунта. Они отвъччали: «Возвратите намъ лейбъроту, иначе въ газармы не пойдемъ». - «Лейбъ-рота за ослушаніе арестована», сказаль Васильчиков'ь, «она въ крьпоости».- — (Иввольте и насъ арестовать; если лейбъ-рота виновата, то и мы съ нею виноваты».--Васильчиковъ приказалъ имъ идти въ крьпость. Весь полкъ пошель безъ мальйшаго сопротивленія. Въ крћпости ихъ размьстили въ разныя казармы. Лейбъ-гренадерскій полкъ, съ зарнженными ружьями, назначенъ быль въ кржпость, въ караулъ къ арестованному полку. Черезъ день Семеновскій польъ по частямъ, за карауломъ, отправленъ въ Кронштадтъ, а оттуда моремъ по разнымъ приморскимъ крьпостямъ; одна только лейбъ-рота оставлена въ Петропавловской крџпости, какъ 
первая, которая возмутилась. Во все время мятежа Семеновскаго полға тишина не была нарушена, и многіе узнали 0 томъ спустя нйскошью дней. 0 всемъ томъ пропсшедшемъ отправленъ въ Троппау къ государю курьеръ ${ }^{249}$ ) съ донесеніемъ, по которому полученъ отъ государя указъ: Ceменовскій полкъ кассировать по частямъ; нижнихъ чиновъ размъстить въ разные отдаленные полки арміи; оФицеровъ перевести по табели о рангахъ, таґже и юнкеровъ, въ армейскіе полки; Шварца отставить; Семеновскій полкъ спормировать лучшими людьми изъ гренадерскаго корпуса, равно оФицеровъ выбрать исправнъйшихъ, но считаться имъ наравнь съ молодою гвардіею $\left.{ }^{230}\right) \ldots$...

219) Петръ Яковлевичъ Чаадаевъ. II. Б.

2з0) 0 Семеновскомъ возмущеніи самъ государь такъ писалъ къ гр. Арагчееву:

$$
\text { «Троппау, Б ноября. (1820) }
$$

Теб̆ должно уже быть иввъ̌стно, любезный Алегсьй Анцреевичъ, несчастное, но въ то же время и постыцное, приключеніе, случившееся въ Семеновскомъ полку. Јегко себъ можно вообразить, какое печальное чувство оно во мнъ произвело. Происшествіе, можно сказать, неслыханное въ нашей арміи. Еще печальнъе, что оно случилось въ гвардіи, а для меня лично еще грустнъе, что именно въ Семеновскомъ полку. Но, съ тобою привыкнувъ говорить со всею откровенностію, скажу тебъ, что никто на свъьтॐ меня не уббъдитъ, чтобы сіе происшествіе было вығышлено солдатами, или происходило единственно, кағъ погазываютъ, отъ жестогаго обращенія съ оными полковника Шварца. Онъ быль всегда извъ̌стегг за хорошаго и исправнаго офицера и командовалъ съ честію полюомъ. Отъ чего же вдругъ сдъзлаться ему варваромъ? По моему убъжжденію, тутъ кроются другія причины. Внушеніе, кажется, было не военное; ибо военный умъ̆ъ бы ихъ заставить взяться за ружье, чего никто изъ нихъ не сдъ́лаль, даже тесака не взяль. ОФицеры же всь усердно старались пресъ̌чь неповиновеніе, но безуспь̆шно. ПІо всему вышеписанному 
Въ то же время государь уғазаль уничтожить всъ Масонскія и Мартинистскія ложи и вснкаго рода тайныя общества и сегты, обязавт подпискою, чтобы никто не осмьлливался продолжать быть членомъ тағовыхъ обществъ, подъ строгимъ взысканіемъ, а до того не только не было препятствія, но даже поощреніе къ самымъ нельпымъ сектамъ.

ваключаго я, что было тутъ внушеніе чуждое, но не военное. Вопросъ возникаетъ: какое же? Сіе трудно рбшшить; признагсь, что я его приписываю Тайнымъ Обществащъ, которыя, по доказательствамъ, которыя мы пмъемъ, въ сообщеніяхъ между собою, и коимъ весьма непріятно наше соединеніе и работа въ Троппау. Цъль возмущенія, кажется, была испугать. Если къ сему присовогупить, что день былъ выбранъ тотъ самый, въ ғоторый императрицы возвратились въ городъ, то, кажется, довольно ясно обнаруживается, что желали ихъ встревожить, дабы сими опасеніями меня принудить бросить занятія наши въ Троппау и воротиться поспьшнъье въ Петербургъ. Но Божьему Промьслу угодно было помъัшать сему и прекратить зло въ начал'ь его. Мъры, на которыя ръшшиля горігушый командиръ съ полкомъ въ посльдствіи, были необходимы, но симь полкъ погубленъ, и уже не можетъ существовать въ его ныньшнемъ составъ. Я почти увъренъ, что если бы съ 1-й гренадерской ротою приличнъе поступили при самощъ началъ, ничего другаго важнаго не проивошло бы. Но уже когда всъ три батальона возмутились, болье не оставалось дйлать, какъ т0, что̀ было исполнено. Сожалью еще, что выбрали кръпости Финляндіи для отправленія въ оныя батальоновъ. Лучше было бы отправить въ Псковъ, Нарву, или тому подобныя мйста.

Ћакъ мнъ ни грустно, но теперешній составъ полка нельзя уже такъ оставить. Онъ потерялъ всякую довъренность. Ты усмотришь ивъ Приказа, при семъ прилагаемаго, какъ я счель приличнымъ поступить, посль здраваго равмышленія.

Для укомпдектованія вновь полка, я предполагаю единственнымъ епособомъ взять первые батальоны полковъ: императора Австрійскаго, короля Прусскаго и Насльъднаго принца. Симъ самымъ полкъ сей опять будетъ хорошъ. Но все не старый, котораго мнъ̆ весьма будетъ жаль. Жаль также и сіи три гренадерскіе полка разстроивать, но нечего болће дъ̆лать. Для поправленія же сихь трехъ полков'ь, полагаю треты ихъ батальоны раздъ̌лить па двое, чъ̌мъ опять будетт 
По возвращеніи государя въ Петербургъ строго надзирали за авторами и журналауи, чтобы ничего не писали 0 конституціяхъ и касающагося до правительства. Гр. Аракчеевъ взяль сильную власть, котораго суровый и жестокій нравъ обратиль къ себъ ненависть всъхъ Русскихъ.

Упомянувб о погздкахз государя на контресьь въ Лайбахг и Верону, и описавъ возстаніе Греиіи, авторв говоpumz: «0бращаюсь опять къ произшествіямъ въ Россіи: содержаніе армій, 1,200,000 войска, стало тягостно Россіи; умножились расходы до чрезвычайности, а потому требовалось умноженіе податей; дворяне объдняли, торговля упала, земледъыьцы не в'ь состояніи стали платить подушныя за чрезвычайнымъ пониженіемъ цъънъ на хлъбъ, потому что некуда стало его сбывать; промышленность изчевла, къ тому же нь̌сколько ль̌ть быль неурожай; довершила все отмъ̆на откупа винной продажи: казна взяла оную на свою отвь̆тственность, почему всъ деньги, бывшія въ оборотй, оставались въ казнь. Государь совсъмь пересталь входить въ гражданскую часть. Злоупотребленія возникли до чрезмърности;

по 8 роть и укомплектовать, взнвъ по одной роть оть каждаго гренадерскаго и карабинернаго полка 2-й и 3-й гренадерскихъ дививій, что̀ и составить 12-ть ротъ, которыя по 4 роты и раздьлятся на каждый полюъ; симъ ротамъ уже послано повельніе идти. Я хотьљль тебя извъ̌стить 0 всемъ. привыкнувъ разсуждать съ тобою 0 всемъ, чт́́ меня ванимаетъ.

Прощай, любевный Алексъй Андреевичъ! Кромь несчастнаго происшествія, у насъ, слава Богу, все хорошо идетъ. Но сіе происшествіе надъљлаетъ довольно толковъ. Напиши мнъ, что́ ты про все сіе узналъ. Тебя на в九̆ъ искренно любящій

\section{Александрг» .}

(Чтенія Общ. Ист. и Др. 1864 г. кн. 4-я). Кромб того нам' сдучилось читать подроб̆ное описаніе этихь дней на франдузскомъ языкో, сочиненное однимъ изъ пострадавшихъ офицеровъ Семеновскаго полка, г. Вадковскимъ. Семеновское возмущеніе, съ внћшней стороны его, описано также въ Запискахъ Ф. Ф. Вигеля. П. Б. 
хотя и посылаемы были сенаторы ревизовать губерніи и смънялись часто губернаторы, но новые не лучше были прежнихъ; нравственность вовсе изчевла, словомъ: Россія никогда не была въ худшемъ состояніи. Государь, думая искоренить злоупотребленія, хотьъљь раздйлить Россію на области, по пяти губерній въ каждой, опредъъляя начальниками иввъстныхъ ему генераловъ, и нйскольћо таковыхъ областей было учреждено, но пользы мало оназалось, почему въ посльвдующемъ царствованіи было отмьнено.

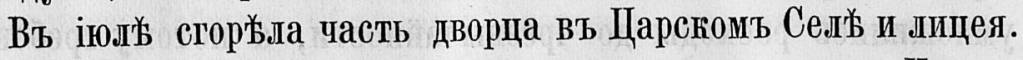
Императоръ былъ чреввычайно огорченъ, сказавъ: «Что до сихъ поръ онъ быль такъ избалованъ счастіемъ, что отъ сего времени страшится противнаго себъљ». На сей случай А. Л. Нарышкинъ сказалъ, что цворецъ царскосельскій сгорьыз отъ того: “Que la cour n’a pas de pompe» ${ }^{251}$ ), ибо тамъ не было пожарныхъ инструментовъ

Вг заключеніи сказано о пољздкь государл въ Таланрогб

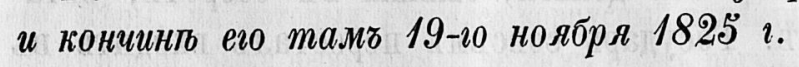

231) Т. е. при дворь ньтть ротре (значитъ и пожарныхъ насосовъ и роскоши). 


\section{СОДЕР ЗЖ А HIE.}

\section{Предисловіе.}

I. Вступленіе. 1766-1779. Родители.-Происхожденіе.-Младенчество у бабки Бутурлиной.-Обученіе въ Витебски, въ Смоденскомъ пансіонъ Эллерта и въ Шкловскомъ кадетскомъ корпусев, стр. 1-10.

II. Времл до прибьтіл на службу въ Преображенскій полкб и нъкоторые анекдоты. 1779-1783. ЖЖизнь И. Н. Корсакова въ Могилевской деревнь Желивль. - Представленіе отца Энгельгардтова Егатеринъ II-й и разговор'ь его съ нею. - Намъстничество гр. З.Г. Чернышева въ Бйлоруссіи.-Сонъ П. Б. Пассека.Екатерина II-я въ Могилевъ..-Размолвка кн. Потемкина съ гр. 3. Г. Чернышевымъ.-Великій князь Павелъ Петровичъ въ Чечерскй. - Фальшивыя ассигнаціи въ Шкловъ̆.- Братья Зановичи и жизнь Зорича въ Шкловъ, стр. $10-35$.

III. Вступленіе ва службу до открывшейсл Турецкой войны въ 1788 годy. Сержанты.-Уборные.-Адъютантство при кн. Потемкинъ. - Возвращеніе монаршей милости кн. Потемкину. Очеркъ жизни кн. Потемкина и его харатеристика.-Придворный бытъ Екатерининскаго викка.-Петербургское высшее общество. - Черты изъ частной жизни кн. Потемкина. -Игельстромъ овладъваетъ ханощъ Шагинъ-Гирееъ.- Появленіе при дворъ Екатерины II-й новаго любимца А. П. Ермолова.-Маскарадъ у Потемкина въ Аничковомъ домъ. - Служба въ Вологодскомъ пьхотномъ полку. - Служба въ Сибирскомъ гренадерскомъ полку. - Путешествіе Егатерины II-й въ полуденную Россію.Граф' Ангальть въ Кричевъ, стр. 35-66.

IV. Туреикая война. Двъ арміи. - Прощаніе съ родителемъ.Кинбурнская побъда. - Гр. М. Ө. Каменскій. - Анекдотъ о ФонъВизинъ. - К. Дашковъ-полковникъ Сибирскаго полка.-Сo- 
ставъ Украинской арміи. - Фельдмаршаль гр. Румянцовъ и его вопнскій бытъ.-Пољздка къ Хотину. - Подвигъ капитана Сакена. - Испытаніе гр. Румянцовымъ квартирмейстеровъ Филиппи и Лена.-Избавленіе оть привычки къ попойкамъ.-Увольненіе въ отпускъ и письмо гр. Румянцова къ отцу Энгельгардтову.-Изученіе военныхъ наукъ.-Образь жизни гр. Румянцова.-Его удаленіе отъ службы.-Военныя дъйствія.-Главная квартира кн. Потемкина. - Шведская война.-Осада и взятіе Киліи.- Княгиня Е. $Ө$. Долгорукая. - Побъда при Мачинжы (Кутузовъ и Репнинъ). - Посльдній пріљздъ кн. Потемкина изъ Петербурга, его распоряженія и кончина. - Каменскій и Каховскій.-Похороны кн. Потемкина. - Ясскій миръ, стр. 66-136.

v. Польска,q война. Пољздка домой.-Несправедливость кн. Репнина.-Поступленіе въ Козловскій мушкетерскій полкъ.Һостюшко и гр. И. Марковъ. - Баронъ Игельстромъ.-Сейиъ в'ь Гроднъ. -Отпускь подъ чужимь именемь.- Грубость Кнорринга.- Командировка къ гр. И. ПІ. Салтыкову. - Тщетная предосторожность. - Военныя дй̆йствія съ Поляками.-Распоряженіе бар. Игельстрома.-Возстаніе и ръзня въ Варшављ.Казнь ген.-майора Арсеньева.-Доблесть С. А. Тучкова.-Подробности военныхъ дъйствій.-Осторожность Репнина и смьлое движеніе Суворова. - Гр. Валеріанъ Зубовъ и полковникъ Рарокъ.-Ввятіе Праги. - Сдача Варшавы. - Споръ о пушкихъ.Характеристика Суворова.-Объдъ у него.-Мандрыкинъ.Переходъ на службу въ Оренбургскій край.-Избраніе Киргизскаго хана, стр. $137-191$.

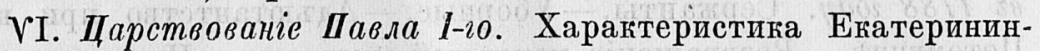
скаго царствованія. - Причина гончины пмператрицы. - Eя духовная. - Новые назначенія и порядки. - Ланжеронъ и Игельстромь.-Обученіе солдать по новому уставу. - Строптивость Игельстрома.- - Павель въ Казани и смотръ войскь на Арскомъ поль. - Благоволеніе государя къ Л. Н. Энгельгардту.-Выходъ въ отставку, стр. 191-217.

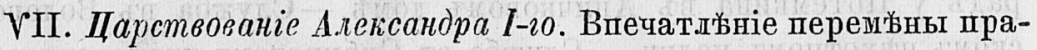
вительственной въ Нижнемъ.-Разсказъ Балашова о Нельсонь. Обозрьиніе событій.-Милиція 1806 года.-1812 годт.-Біографическія подробности о С. К. Вязмитиновъ. - Пожарь царсгосельскато дворца.- Вовмущеніе Семеновскаго полка, стр. 218-238. 


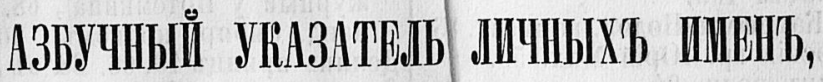

\section{УПОМИНАЕМЫХЪ ВЪ ЗАПИСКАХЪ Д. В. ЭНГЕЛЬГАРДТА.}

Авель монахъ-прорицатель 217.

Александра Павловна вел. княжна 194.

Александръ Павловичъ импер. 207. 209. 210 (въ Казани). 217-238.

Алексъй Михайловичъ царь 2.

Амвросій Зертисъ-Каменскій арх. Московскій 193.

Амвросій Подобъдовъ, арх . Казан с кій 213.

Амвросій Серебрянниковъ, еписк. Xepc. 135.

Ангальть гр. Өед. Евст. 62.

Ангальтъ-Бернбургъ пр. 117.

Анна Іоанновна импер. 2.

Антонъ Ульрихъ пр. 192.

Апраксинъ Степ. Степ. ген. м. 158. 160.

Арактеевъ гр. А-й Андр. 196. 224. 230 (великодушіе). 235-237 (письмо къ нему импер. Александра).

Арсеньевъ Никол. Дмитр. ген. м. 142. 148. 162-164 (пльнъ у Поляковъ) 179. 180.188.

Арсеньевъ маіоръ 148. 176. 190.

Аршеневскій Як. Степ. 2.

$$
\text { * * }
$$

Багратіонъ кн. Петръ Иван. 172. 173 (подвиги въ Польшь).

Багржевт бригал. 155.

Бакунинъ подполк. 125.

Балашовъ А-т Дм. ген. м. 219. 220 (въ Ревель).

Барыковт полк. 208

Барятинская княж. Екат. Өед. „̋6.

Баталъ-паша 117.

Батуринъ маiоръ 162.
Бахметевъ Н. И. Моск. оберъ-полиц. 193.

Бахметевъ Н. Н. воен. Оренб. губ. 213.

Безбородко, гр. А-т Андр. 136. 158. 19.. (Слова при заключеніи Ясскаго мира).

Белли, флота кап. 203 (занимаеть Неаполь).

Бердяевъ, генер. квартермистръ, Н. М. 7 7. 88 .

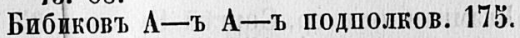
179.

Бибиковъ Юрій Богд. 117.

Бишевскій Польскій полк. 161.

Блондель инжен. 95.

Богдановъ Н. И. арт. маіоръ 150. 1 1.

Бонапарте 216.

Бонафика пивица 18.

Брауншвейгъ Петръ Мих. 6.

Браницкая гр. Ал-а Васил. 49. 12 . 127. 128.

Браницкій гетм. 125.

Бригонцій архит. 18.

Буксгевденъ гр. Өед. Өед. 179. 187. Булгаковъ, полковн. 126.

Булгаковъ Як. Ив. 66. 67. 123.

Бутурлинт гр. 58 .

Бутурлинъ Левъ Петр. 3.

Бутурлина Нат. Өед. 3.

Бухгольцъ, Прусск. мин. 143.

Бълинскій, гр. маршалъ Польск. сейма $144-147$.

Бълякъ, Польск. ген. 165.169.

$$
\text { * * }
$$

Вавржецкій, Польск. ген. 165. 172. 180. 118. 
Вадковскій, офицеръ Семен. полка 237. Гудовичь гр. Ив. Вас. 111. 118. 123.

Ванжура бар. Австр. ротм. 24.

Васильчиковъ Иллар. Вас. 234.

Вахмейстеръ гр. Шведскій вице адм. 83.

Вимптенъ маіоръ 160.

Виртембергскій приндъ 123.124 (кснчина).

Витгенштейнъ гр. Петръ Христ. 1:1.

Витковичева бригад-а 4.

Витть Софья 105.

Виттъ, Каменецъ-Подол. комменд. 5.

Віельгорскій гр. Юрій Мих. 56.

Владычинъ полк. 94.

Вобанъ 95.

Волкй Прусскій ген. 161.

Волков' А. А., Московскій полщм. 225.

Волконскій кн. Григ. Сем. 75. 77.78. 94. 102. 118. 121. 122. 129. 37 . 138.

Володковичева панья 162

Вольфортъ іезуитъ 6.

ВольФъ, полк. 180. 181.

Высоцкій, зять Потемкина 41.

Вяземская княг. Вжра Өед. 105. 227.

Вяземскій кн. А-т Алексъев. 12.

Вяземскій кн. Петръ Авдр. 71. 72. 105. 228.

Вязмитинова Александра Ник. 58. 59. 228-231.

Вазмитинов' гр. Сергъй Кузмич; 25. (его сочиненіе), 59 (женитьба), 68. 71. 73. 81. 100. 190 (Оренб. ген. ryб́.) 196. 200. 201. 228-231.

$$
\text { * * }
$$

Гагарина княг. Анна Петр. 214.

Гагарина княг. Праск. Юр. 105.

Гагаринъ кн. Пав. Гавр. 214.

Гагаринъ кн. Өед. Серг., полк. 103. 160 (кончина).

Гассанъ-паша 100. 103.

Гедропчь, Польск. полк. 163. 172. 174.

Гельвигъ, сек. маіоръ 102. 103.

Георгій Конисскій, арх. Мог. 2(.24. (панагія) . 25. 61 (Ржчь Екатеринб)

Гербертъ Австр. полк. 88.

Германъ бар. Ив. Ив. 117. 214. 216.

Голицынъ кн. Серг. Өед. 118-120.

Головатый кошевой 113.

Головина гр. Варв. Никол. 105.

Гололобовъ адъют. 166.

Гофманъ, подполк. 179.

Грабовскій, Польск. ген. 172.

Грейгъ Сам. Карл. адм. 83.

Грековъ, Донской полк. 76.

Грузинскій кн. Егоръ Алекс. 218.

124.

Густавъ III-й король ІІІвед. 82.

Густавъ IV-й король. ІІвед. 194. 195.

$$
\text { * * }
$$

Дашкова кн. Екат. Ром. 37. 38 (внушенія противъ Потемкина).

Дашковъ кн. Пав. Михаил. 56 (дежурный у Потөмкина), 68. 73 (команд. Сибир. полкомъ). 90. 91. 95. Делинь принцъ 43.66. 88 (въ Яссахъ). Денисовъ Өед. Петр., Донской атам. 15้ $-157.176-181$.

Державинъ Гавр. Ром. 125.

Дернбинъ оруж. заводч. 224.

Дерфельденъ Вильг. Христоф. 98. 166-168. $170-174$.

Дзелинскій Польск. полк. 15ૅ. 158-160. Дивова 58.

Дмитревскій актеръ Ив. Аөан. 48.

Долгорукая княг. Екат. Александр. 29 (въ ПІклов

Долгорукая княг. Екат. Өед. 丂5. 105. 114. 115 (въ Бендерахъ).

Долгорукій кн. Вас. Вас. Э6. 60. 108 (оскорбленіе ему Потемкина).

Долгорукій кн. Юрій Влад. 222 (нач ополченія)

Домашневт Сер. Гер. 38.

Домбровскій Польск. полк. 165. 173.

Древичь полк. 6.9.

Дрейеръ капит. 59.

$$
\text { * * }
$$

Екатерина II-я 11-16 (разговоръ съ Н. Б. Энгельгардтомъ). 21. 22. 24. 25. 34. 36. 41. 42. 45. 58. 65. 66 (coюзъ съ Австріею). 67. 114. 125. 126. 128. 129. 136. 146. 179. 191-196 (характеристика ея въка). 198. 217. Елисавета Петровна имп. 192.

Елымовъ кн., сержантъ 114.

Ермоловъ Александръ Петр., паво рить 54-56. 59.

Ермоловъ Алексьй Петр. 171.

Еропкинт Петры Дм. 194.

$$
\text { * * }
$$

Загряжскій, ген. пор. 154. 165. 166. $168-171$.

Зайончекъ, Пол. ген. 16ら-167.

Залуцкая гр. 148.

Зановичи Предиславъ и Стефанъ 31. 32. 34.

Захаровъ Ив. Сем. 138. 
Зенкевичь маіоръ 206.

Зотовъ Зах. Конст. 38. 64.

Зоричь Сем. Гавр. 9. 20. 24 (пріемъ Екатерины). 27. 29-32. 34.

Зубовт гр. Валер. Александр. 141. 166. 168. 171. 174. 175 (рана). 190. Зубовъ гр. Никол. Алексан. 160. 195. Зубовъ кн. Шлат. Александр. 109. 125. 213

Зубовы графы 192.

Зюдерманландскій герц. 82. 194.

$$
\text { * * }
$$

Игельстромъ гр. Осипъ Андр. Э2(захватъ Пагинъ-Гирея) 142. 143. 148. 153-162 (поведеніе въ Польшьъ). 200-202. 204-206. 208. 212. 213 (вт Оренб. краю и Казани).

Игельстром', подполк. 161.

Изанъ -бей, Турецк. кн. 30. 34.

Ираклій, царь Груз. 66.

$$
\text { * * }
$$

Іоаннъ Антоновичь 192. 193.

Іозечовичь, Могил. помьщ. 11.

Іордышъ, Австр. ген. 88.

Іоркскій герц. 214.

Іосифъ II, имп. Германскій 16. 19. 24. 25. 43. 6ว. 66. 68. 106.

$$
\text { * * }
$$$$
\text { * }
$$

Каменскій гр. Михаиль Өед. 67 (презрьине къ подарку имп-цы) 68.70 (поддъзывается къ Потемкину). 74. 86. 91. 94. 97. 98. 126-129 (поступки по смерти Потемкина). 196.

Каменскіӥ, гр. Серг. Михаил. подполк. 126. 128 (отецъ бьеть его). 181.

Кантакузенъ кн. 96.

Карачай Австр. ген. 88.

Карль XII, кор. IIIвед. 65

Каховскій гр. Михаиль Вас. 127-129. 140. 142. 165 .

Кацаврикъ іезуить 6 .

Кашкаровъ, капит. Семен. полка 233. Кашталинскій Матв. Өед., обер'ь-церемон. Јั0.

Клугенъ прем. маіоръ 94. 159. 160.

Ключаревъ Өед. Петр., секрет. гр. Чернышева 26.

Кноррингъ Богд. Өед. 75 (бригад). 150-152. 169 (его грубость).

Кобенцель гр. Люд., Австр. посл. 60.

Кобургскій принцъ 74. 99. 100. 104. 183.
Когорнъ, инжен. 95 .

Когцейнъ, ген, адъют. Іосифа II-го, 21.

Козинскій Казанск. гр. губ. 213.

Кологривов' Петръ Алегсандр. 105.

Колонтай 16ц. 178.

Коновницынъ гр. Петрт, Шетр. 169.

Константинъ Павловичь вел. кн. 207. 215.

Копьевъ Алексъй Дан. 181.

Корсаковт Ив. Никол., фаворитъ 10. 11 (его жизнь въ Могил. деревнъ).

Косаковскій Польск., гетм. 162. 163. Костроминъ, Нижегор. купецъ 219.

Коотюшко Тадеушъ 141 (дъло подт Мурахвой) 156.157 .159 .162 .164 (диктаторъ) 165. 167. 168. 173.

Кредетниковт Михаиль Никит. 99. 100. 107. 108. 140. 142

Крохъ, Прусскій маіоръ. 180. 181.

Крузе Александръ Ив., адм. 107.

Кузиинъ, маіоръ 82.

Кузшиы братья вахмистры 115

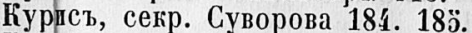

Кутайсовъ гр. Ив. Павл. 197.

Кутейниковъ, казачій стартина 69.

Кутузовъ кн. Михаиль Јаріон. 99. 117-122 (подъ Мачиномъ). 224. 226.

$$
\text { * * }
$$

Лавровъ, бригадъ-маіорь 209.

Ланжеронъ гр. Александръ Өед. 199. 201. 202. 206. 207. 211. 212 (см'лость съ Павломъ). 214.

Јанской Александрь Дм., Фаворитъ 10. 38. 49. ว2 (кончина). รั4.

Лансвой Никол. Серг. 150. 152. 153.

Ласси Морицъ Петр. 76. 101. 169 (ген. маіоръ). 208. 209-213 (Казанскій военн. губ.).

Лашкаревъ, бригад. 127.

Лебедева дъвица 8.

Лёневё мадамъ 6 .

Ленъ, квартирмейст. 89. 90.

Леонидовъ А. Я., ген. маіоръ 76.

Леопольдъ II, импер. Римскій 106.

Лецкій, ген. маіоръ 209. 211 (принимаеть у себя Павла).

Лопухинъ кн. Петръ Васил. 214.

Лукезини марк. 87. 143.

Людовикъ X VIII. 227.

Лыкопинъ, подполк. 156.

$$
\text { * * }
$$

Мадалинскій, Польск. ген. 155.156. Мазепа 113 
IV.

Макрановскій, Польск, ген. 162. 168. Нельсонъ, адм. 219. 220 (подъ Реве173.

Малґевъ, предс. Могил. угол. пал. Неплюевъ Никол. Ив., Минскій губ. 29. 33 .

Мамоновъ гр. Александръ Матв, , фаворить 39. 55. 59. 60. 64.108.

Мандрыкинъ, сегр. Суворова 184. 188. 189.

Марія Өедоровна импер. 22. 25. 40.. 123. 224.

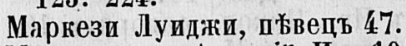

Марковъ гр. Аркадій Ив. 194.

Марков' гр. Ираклій Ив. 141 (дозло подъ Мурахвой).

Масальскій кн. бискупъ Виленскій 16 б.

Массена 216.

Массоть, медикъ 125.

Матюшкина гр. Соф. Дм. 56.

Медеръ 75 (бригад.). 88 100. 119 (лейтен.).

Мейеръ, подполк. 167.

Мекнобъ, ген. м. 109-113. 116.

Меллеръ-Закомельскій Ив. Ив. 109. 110.

Мелинъ графинг 29.

Мелинъ гр. 76. 140.142.

Мелиссино Пегръ Ив., ген. м. 24.

Мельгуновъ, тен. м. 76.

Мельгунов' Алексъй Џетр. 12.

Мещерскій кн. Прокофій Вас. 30.200. 201.

Милашевичь, ген. м. 118. 159. 160. 179.

Мировичь 192. 193.

Михаиловъ, вице-губ. Минскій 148. 149.

Михаиль Павловичь вел. князь 233. 234.

Михельсонъ Ив. Ив. 104. 209.

Мовтегю гр. 35.

Мордвиновъ Никол. Сем. 75.

Морсаньи 49.

Мостовскій гр. 179.

Мусинъ-Пушкинъ гр. Валент. Плат. 83. 107.196.

Мягкой, подполк. 126.

$$
\text { * * }
$$

Наврозова Варвара Никол. 210.

Наполеонъ 224. 225. 227.

Нарышкина Марья Ант. 146.

Нарышкинъ Александрт Львовись 238.

Нарышкинъ Левъ Александр., об. птталм. 48. 50. 61.

Нассау-Зигенъ пр. 75. 84. 107. 114. 117.

Наталья Алексъевна вел. княг. 22.

Нелидовъ, ген. ад. 211. 212. 149.

Неранчичь брать Зорича 31. 32.

Николай Шавловичь вел. князь 234.

Новицкій 87 (бригад.). 161. 162 (ген. м.).

Обольяниновъ Петръ Хрисанө. 196.

Овсянников'ь Осипт Ив. 7.

Ожаровскіӥ, Польск. ген. 164.

Оленинъ, поруч. 184. 185.

Орлова графиня 225.

Орловъ Вас. Петр., Донской атам. 101.

Орловъ кн. Григ. Григ. 13.

Орловы графы 12.

Остерман'ъ гр. Ив. Андр. 42.48.

Павелъ Петровичь вел. кн. 22. 25

(пољздка въ чужіе края). 45. 47 (въ Петерб.); императоръ: 195-217. 219.

Паленбахъ, полковн. 142.

Панинъ гр. Никита Ив. 71.

Панинъ гр. Петръ Ив. 71.

Панкратьевъ Петръ Прок. нач. канц. Репвина 122. 138. 139.

Пассекъ Петръ Богдан. 12. 19 (сонъ). 24. 25. 26 (намъстн. БЪлорусск).

Петръ Великій 40. 65. 121.

Петръ ІІІ-й, импер. 13. 21. 41. 195 (погребеніе).

Пикъ, танцм. $\{9$.

Пистеръ, ген. квартерм. 121. 160.

Плото баронъ, поруч. артил. 136.

Полторацкій Дм. Марк. 227.

Поль Джонсъ 75.

Поповъ Вас. Степ. 39. 127-129. 136.

Потемкпва Праск. Андр. 105.

Потемкинъ, послан. въ Англію 40.

Потемкин' кн. Григ. Алексавдр. 2. 20. 22. 23. 26. 27 (розыскъ фальш. ассигн.). 29. 36. 39. 40. 42. 51. 55. 60. 65. 67. 68.70 (поступокъ съ Каменскимъ) 71 (съ Фон-Визинымъ) 74. 84. 85. 93 (Очаковъ), 97 (главнокоманд.). 104-106 (жизнь въ Яссахъ). 108. 114-116 (въ Бендерахъ). 123-136 (послбдніе мбсяцы, кончина и погребеніе). 210. 229.

Потемкинъ Павелъ Серг. 99. 108.

Потоцкая гр. (ур. Виттъ). 85. 105.

Потоцкій гр. 179.

Потодкій гр. Феликсъ Франц. 105. 
Протасова Анна Степ., камм. фрейлина 49.60.

Пугачовъ 4. 209.

Пушкинъ Алексъй Михаил. 227.

Пъвцовъ, ген. м. 207.

$$
\text { * * }
$$

Разумовскій гр. Кирил' Гр. 39. 48.

Разумовскій гр. Левъ Кир. 39.

Рарокъ, полк. 154. 16ว. 171. 174. 175. кончина).

Раутенфельдь, ген. м. 146.

Рахмановъ Гавр. Михапл., полк. 98. ген. м. 155.157.

Рекъ, ген. м. 69.

Репнинъ кн. Никол. Вас. 85. 97-104. 118-124 (подъ Мачиномъ). 137-140 (уклончивость). 154. 168. 169. 171174 (опасливость). 190. 196.

Ржевскій, подполк. 186.

Ржевскій Степ. Матв., ген. пор. 18.

Ржевусскіӥ 125.

Рибасъ Осипъ Михаил. 118. 119. 123. 127. 128.

Рибопьеръ Ив. Александр. 39.

Римскій Корсаковъ Александръ Мих. 214. 216.

Розенбергъ, ген. 214.

Розетти, танцовщ. 49

Рокасовскій И. Н., полковн. 140. 149. Роштейнъ, капит. 62. 63. 90.

Румянцовъ Задунайскій гр. Петръ Александр. 20-22. 24. 26 (угощаетъ Цавла Цетр. въ Гомел') 42. 68. 70. 74. 76-81. 84. 85. 87-90 (исиытываетъ квартермистровъ) . 91-94 (отпускъ Энгельгардта). 95 . 96 (жизнь въ Яссахъ). 97. 98 (отставка). 100. 106 (жизвь подъ Яссами). 130 (отзывъ о немъ солдатъ). 172. 203 (кончина). 229.

Руничь, сержанть 114.

Рыбушкинъ, Казанск. помьщ. 204.

Сабуровъ 162.

Сакенъ, тлота кап. 84.

Сакенъ гр. Фаб. Вильг, 151. 152.

Сальморанъ, учит. 31. 32.

Салтыковъ гр. Иванъ Петр. 68. 74. 81. 85. 86. 91. 152-154. 196.

Салтыковъ гр. Нетръ Семен. 193.

Самойлова гр. 41. 105.

Самойловъ гр. Александръ Никол. 41. 109-111 (подъ Киліею). 127. 128.

Сандерсъ, докт. 35.

Can'sra, rp. 18.
Сарти Iоc., муз. 47. 105.

Сахаровъ, Казанск. помьщ. 206.

Сегюръ гр. Людов. Филиппъ 1. 61.

Секеривъ, капит. арт. 112.

Семеновъ, капр. 147. 151.

Сестренцевичь, катол. архіеп. 20.

Сиверсъ, полковн. 86. 88. 91.

Сиверсъ гр. Яковт Ефимов. 142. 143. 146-148.

Сигизмундъ III, король Польск. 2.

Сираковскіӥ, Шольскій ген. 169.171. 172.

Слћпушкинъ, провіантм. $187-189$.

Спечинскій 11วั. 116 (святцы).

Сплени, Австр. ген. 88.

Станиславъ Понятовскій, король Польскій 6马. 14马 - 147. 161. $178-180$. (покореніч Варшавы и пріем' у Суворова). 190.

Стреноуховъ 3.

Стурдза 96.

Суворовъ кв. Александръ Васил. 67 (отказ. отъ подарка Екат.) . 68-70. 85 (Очаковъ). 97. 100. 104. 106 (уваженіе къ Румяндову). 108. 114. 116. 117. $172-175$. $178-180$ (депутація изъ Варшавы). $181-189$ (образъ жизни и анекдоты). 198 (отставка). $215,216$.

Сухуржевскій, Нольск. депут. 145.

$$
\text { * * }
$$

Талызинъ А.лександръ Өед., камерг. 39. Татищевъ Николай Алексъев., ген.-м. 35.

Татищевъ, Казанскій помбъ., Р. Е. 225. Терскій Аркад. Ив., ген. рекетм. 114. Терскій-сынъ, прапорщ. 114.

Тимонъ, мед. 125.

Тимqенко, камерд. Суворова 185.

Титов' маiор' 160 .

Тищевъ, ген.-м. 143. 161.

Тоди, пвв. 47.

Толстой Ив Матв., ген.-м. 75. 129. Тормасовъ, ген.-м. 156. 157 (пораженъ Костюшкою).

Трейденъ, поруч. 153.154.

Тутолминъ Тимоө. Ив. 150.

Тучковъ Сергьй Алексьев., кап. арт. 163. 164.

Тюнинъ, сержантъ 114.

Упаковъ, Өед. Өед. 75.

$$
\text { * * }
$$

Фамвнцынъ, ген.-м. 68. 
VI.

Ферзенъ гр. Ив. Астаө. 140.142. 153. ШШварцъ, полковн. Семен. полка 232162. 165. 168. 173. 175. $186-189$. Филиппи, полковн. 76. 88. 89. Филидштальскій принцъ, полковн. 3. Философовъ, Смол. виде-губ. 201. Фицъ-Гербертъ, Англ. послан. 61. 66. Фонъ-Визинъ Ден. Ив. 71. 72. Фрейлихъ, адъют. гр. Чернышова 26. Фридрихъ Великій 21. 22.

Фридрихъ Вильгельмъ II, король Прусск. 143. 154. 165. 168. 173. 181. Фризель, подполк. 156.

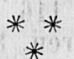

Хомутовъ, бригад. 63. 64.

Хорватъ Д. И., ротм. 30. 139.

Хрущовъ, ген.-м. 155. 157.

$$
\text { * * }
$$

Дезырскій подпор. 114.

Диціяновъ кн. Пав. Дм, 164. 172.

$$
\text { * * }
$$

Чаадаевт, Петръ Яковл. 23э.

Чапега кошевой 174.

Чарторижскій кн. 167 (разореніе его имънія).

Чернышева гр. Анна Род. 21. 25.

Чернышевъ гр. Григ. Ив. Ј̆6.

Чернышевъ гр. Зах. Грит. 14. 16. 17. 20-26. 228. 229 .

Чернышевъ гр. Ив. Григ. 61.

Чертковъ капит. 114.

पертковъ Евгр. Александ., камерг. 39.

Чесменскій Алегсандръ Алексъев., полк. 153.

Четвертинская княжна Марія Авт. 145.

Четвертинскій кн. 164.

Чиркова Любовь Петр. 224. 225.

Чп ховскій, Польск. ген. 158.

Чичаговъ Вас. Яковл., адм. 107.

$$
\text { * * }
$$

Шагинъ-Гирей, ханъ Крымскій ӭ1. 53. 54 (ссылға въ Воровежъ).

Памшевъ, ген.-м. 87.

Шаховской кн. Борисъ Григор. 86. 91. 96.97 .

235.

ШІепелевъ, маіоръ 167 (ложное отлиपie).

IIІереметевъ Вас. Серг. 109. 111.

ШІпарманъ, подполк. 175.

ШІтакельбергъ, гр. Отто Магнусъ 87. 125. 142.

ІІІубивъ, Смоленск. помњщ. 227.

Шуваловъ Ив. Ив. 61. 63. 71.

Шуваловъ гр. Петръ Ив. 13.

$$
\text { * * }
$$

Шелинъ Матв. Мєхаил. оберъ-кварт. 10.

Пербатова княжна Дарья Өед. 108. Пербаqевъ С. Н. 168.

$$
\text { * * }
$$

Яблоновскій, Польск. подполк. 176.

Языковъ, полковн. 163. 164.

Яцунскій, подполк. 116.

$$
\text { ** }
$$

Юшковъ, полковн. 60 .

$$
\text { ** * }
$$

Эллертъ Т. 8.

Эльмпть 58. 68. 74. 86.

Әльмптъ фрейлина 58.

Энгельгардтъ Александра Никол. 5̆8. 99. Энгельгардтъ Варвара Никол. 6. 26. Энтельгардтъ Над. Шетр. 2. 3.

Энгельгардтъ Вас. Андр. 41.

Энгельгардть Вас. Вас. 9. 41. 76. 106. 128

Әнгельгардтъ Никол. Богд. 2. 3. (воевода въ Витебскъ), 7 (вице-губ. въ Полоцкь) 9 (въ Могилевь) 12-16 (разговоръ съ Екатериною). 25 (губ. въ Могилевъ). 26 (разговоръ ст Павломъ Петр.). 29 (разговоръ съ Потемкинымъ . 32. 69. 91. 93. 137. 140. 147. 210. 224. 226. 227 (спасеніе отъ Французовъ).

Энгельгардтъ Цавелъ Ив., Смол. помйщикъ 227.

Энгельгардть Вернеръ 2.

Эртель Өед. Өед., маіоръ 202. 206. 


\section{ОПЕЧАТ КИ.}

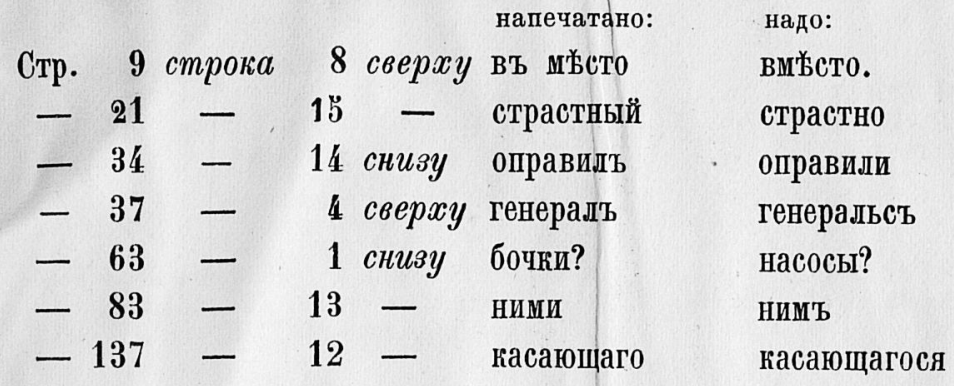




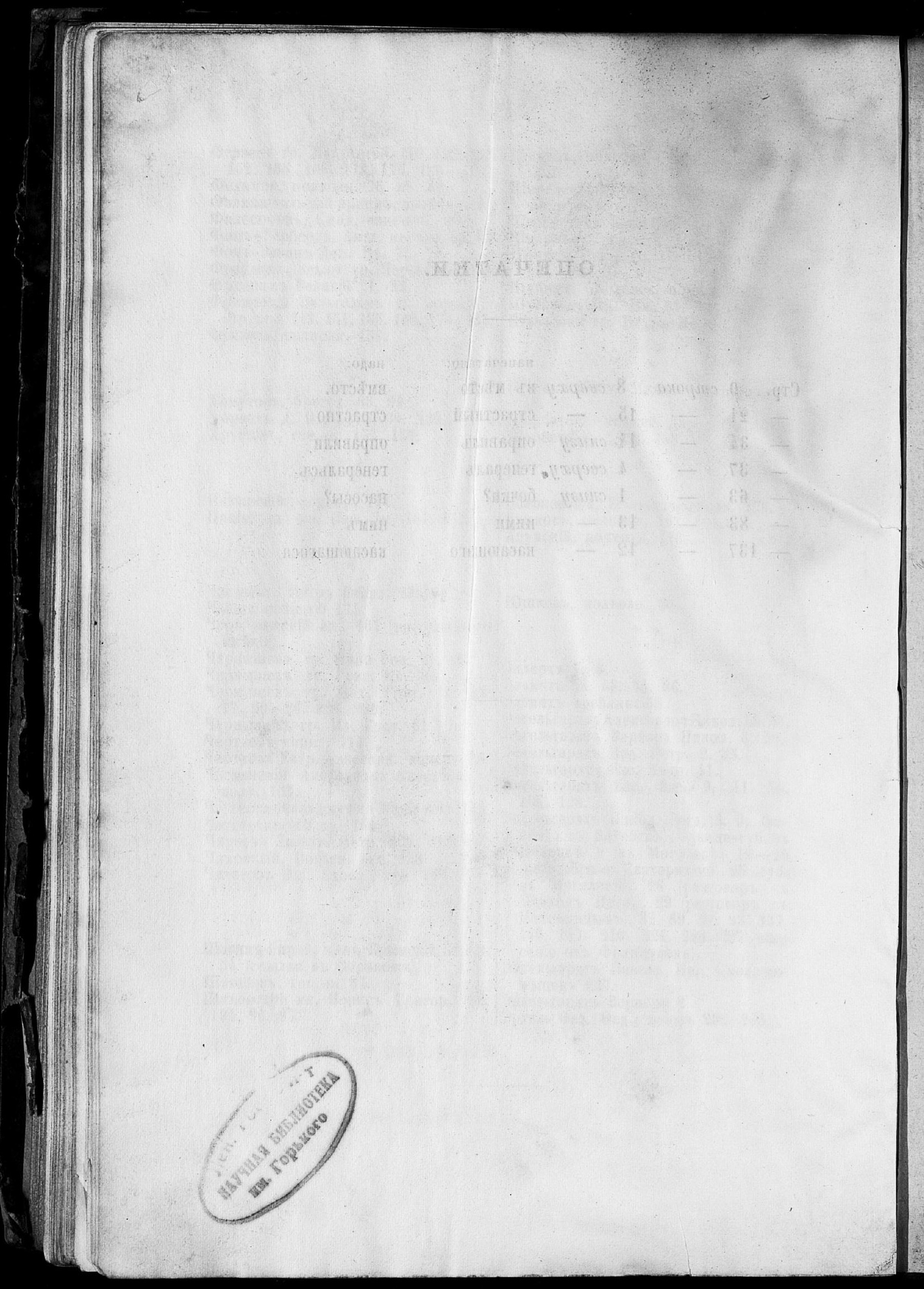




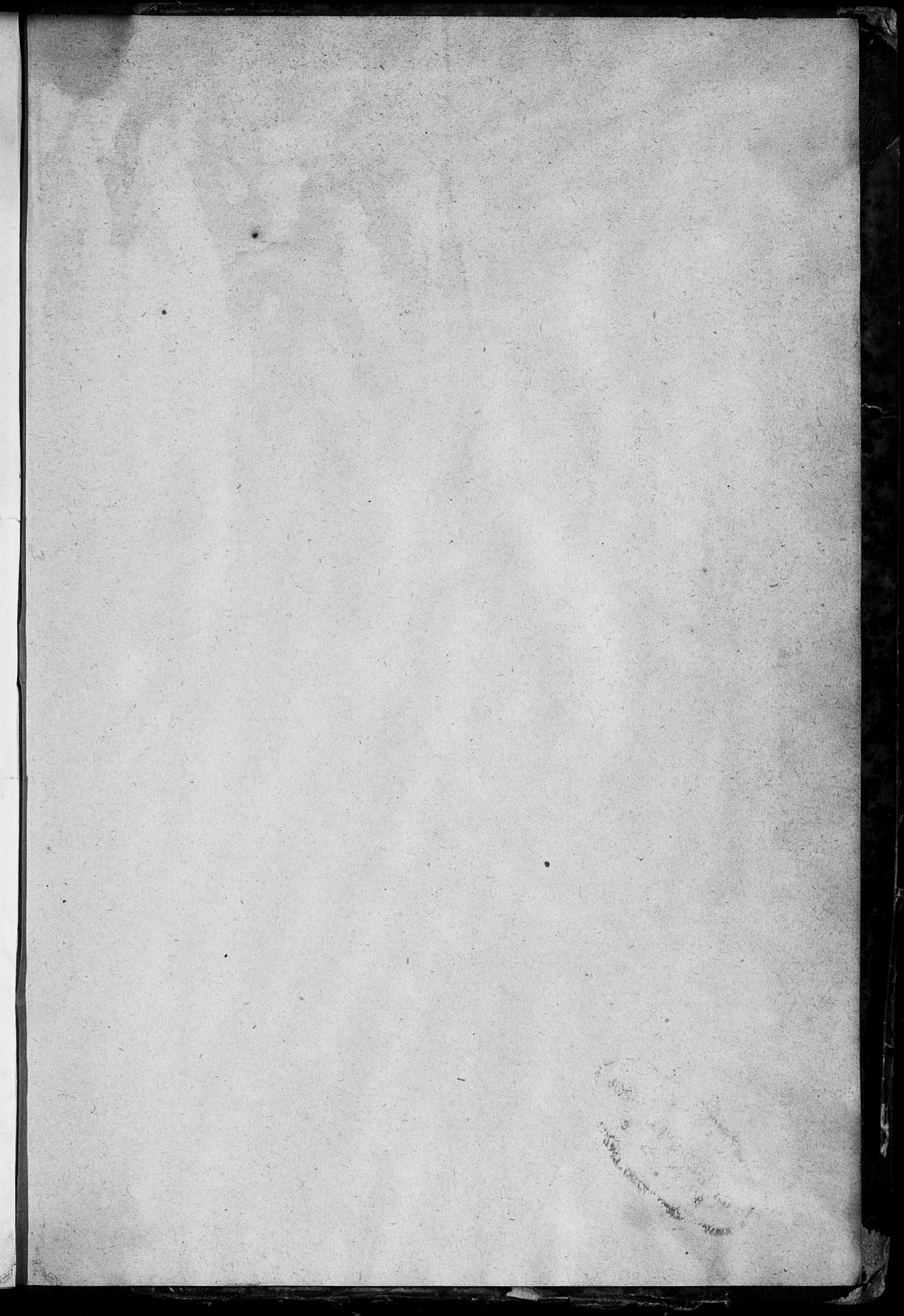






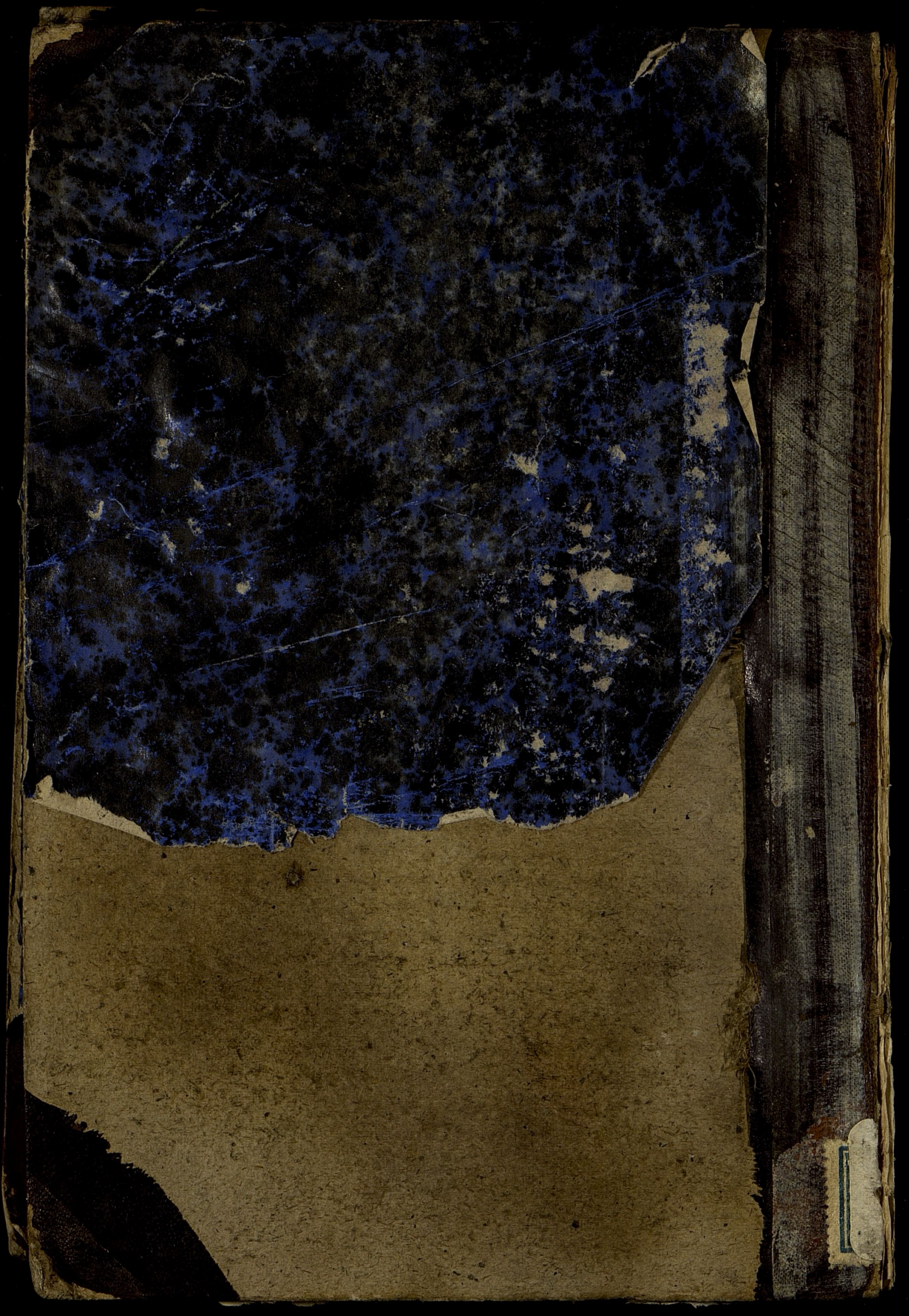

